UNIVERSIDADE DE SÃO PAULO

FACULDADE DE FILOSOFIA LETRAS E CIÊNCIAS HUMANAS

DEPARTAMENTO DE LETRAS CLÁSSICAS E VERNÁCULAS

PROGRAMA DE PÓS-GRADUAÇÃO EM ESTUDOS COMPARADOS DE LITERATURAS DE LÍNGUA PORTUGUESA

JOSÉ CARVALHO VANZELLI

EÇA DE QUEIRÓS E O EXTREMO ORIENTE

(VERSÃO CORRIGIDA)

São Paulo

2013 


\section{EÇA DE QUEIRÓS E O EXTREMO ORIENTE (VERSÃO CORRIGIDA)}

Dissertação apresentada ao Programa de Pós Graduação em Estudos Comparados de Literaturas de Língua Portuguesa, do Departamento de Letras Clássicas e Vernáculas da Faculdade de Filosofia, Letras e Ciências Humanas da Universidade de São Paulo, para a obtenção do título de mestre em Letras.

Área de Concentração: Estudos Comparados de Literaturas de Língua Portuguesa

Orientadora: Profa. Dra. Aparecida de Fátima Bueno

São Paulo 
Autorizo a reprodução e divulgação total ou parcial deste trabalho, por qualquer meio convencional ou eletrônico, para fins de estudo ou pesquisa, desde que citada a fonte

Vanzelli, José Carvalho

VV217e Eça de Queirós e o Extremo Oriente / José Carvalho Vanzelli ; orientadora Aparecida de Fátima Bueno. São Paulo, 2013.

$218 f$.

Dissertação (mestrado) - Faculdade de Filosofia, Letras e Ciências Humanas da Universidade de São Paulo.

Departamento de Letras Clássicas e Vernáculas. Área de Concentração: Estudos Comparados de Literaturas de Língua Portuguesa

1. Eça de Queirós. 2. Extremo Oriente. 3. Orientalismo Literário. 4. Século XIX. I. Bueno, Aparecida de Fátima, orient. II. Título. 
Nome: VANZELLI, José Carvalho

Título: Eça de Queirós e o Extremo Oriente

Dissertação apresentada ao Programa de Pós

Graduação em Estudos Comparados de

Literaturas de Língua Portuguesa, do

Departamento de Letras Clássicas e

Vernáculas da Faculdade de Filosofia, Letras e

Ciências Humanas da Universidade de São

Paulo, para a obtenção do título de mestre em Letras.

Área de Concentração: Estudos Comparados de Literaturas de Língua Portuguesa

Aprovado em:

\section{Banca Examinadora}

Prof. Dr.

Instituição:

Julgamento:

Assinatura:

Prof. Dr.

Instituição:

Julgamento:

Assinatura:

Prof. Dr.

Instituição:

Julgamento:

Assinatura: 
Ao meu avô Afonso Gomes de Carvalho (in memoriam), um dos principais responsáveis por eu ter descoberto o mundo das Letras e, principalmente, da literatura. Saudade e gratidão. 


\section{AGRADECIMENTOS}

À Fátima, que gentilmente me acolheu como orientando, pelas conversas, pelos ensinamentos, pela paciência e, principalmente, por ter confiado em mim e acreditado em minha pesquisa.

Aos meus pais, Antonio Carlos e Marília, e irmão, Lucas, pelo apoio, incentivo, amor e carinho.

À minha esposa, Ahra, pela ajuda e pelo incentivo; pela compreensão nos momentos difíceis da pesquisa; pelo amor, carinho, apoio e companheirismo de todos os dias.

Ao professor Hélder Garmes, pelo convívio, pelas aulas, pelas várias conversas e sugestões preciosas ao longo de toda a pesquisa, que contribuíram para amadurecimento da mesma. Agradeço também a participação na banca de qualificação e o cuidado com que leu meu trabalho.

Ao professor Sérgio Nazar David, pela participação na banca de qualificação, pela leitura cuidadosa de meu texto, assim como pelas sugestões, bibliografias e palavras de incentivo que permitiram com que meu trabalho fosse realizado com ainda mais empenho e motivação.

Ao professor David Frier, pelo contato e pela bibliografia cedida.

Ao amigo Rodrigo Moura Lima de Aragão, pela amizade, pela imensa ajuda, pelos conselhos e conversas, não apenas durante o período do mestrado, mas desde nossa iniciação científica.

À amiga Érika Horigoshi, pelas trocas de textos, pelas sugestões, pelo apoio, pelas ideias muitas vezes iluminadoras e por toda a interlocução ao longo deste processo.

Aos amigos do Grupo Eça, por me acolherem no grupo, pelo convívio e pelas sugestões que, direta ou indiretamente, foram fundamentais para o amadurecimento deste trabalho.

À amiga Andrea Trench de Castro pelas conversas e sugestões bibliográficas.

A Fundação de Amparo à Pesquisa do Estado de São Paulo (FAPESP), cujo apoio financeiro possibilitou a realização deste projeto.

E a todos aqui não citados nomeadamente, mas que direta ou indiretamente contribuíram para que este trabalho fosse desenvolvido. 


\section{RESUMO}

O presente estudo apresenta uma análise das representações do Extremo Oriente nas obras do escritor português Eça de Queirós (1845-1900). Através de um estudo amplo de obras de diversos momentos da carreira do escritor português, procuramos demonstrar que o Extremo Oriente queirosiano estabelece uma representação complexa das relações Ocidente-Oriente, não se limitando às imagens cristalizadas do Oriente na literatura portuguesa, em que se destacam o exotismo e o caráter imaginário. Como principais pilares teóricos, nos apoiamos nas teorias orientalistas, principalmente as de Raymond Schwab (1950) e Edward Said (1978), e da fortuna crítica queirosiana. Realizamos uma análise comparativa de textos ficcionais e não ficcionais do autor que, nomeadamente, compreende os romances O Mistério da Estrada de Sintra (1870), escrito juntamente com Ramalho Ortigão, O Mandarim (1880) e A Correspondência de Fradique Mendes (1900); os textos de imprensa “A Marinha e as Colônias” (1871), “A Pitoresca História da Revolta da Índia” (1871), “A França e o Sião” (1893), “Chineses e Japoneses" (1894), “A Propósito da Doutrina Monroe e do Nativismo" (1896), "França e Sião" (1897); e o relatório consular A Emigração como Força Civilizadora (1979).

Palavras-chave: Eça de Queirós; Extremo Oriente; Orientalismo Literário; Século XIX. 


\begin{abstract}
This study presents an analysis of the representations of the Far East in the works of the Portuguese writer Eça de Queirós (1845-1900). Through a comprehensive study of works produced by the Portuguese author at different moments of his career, we intend to demonstrate that the Queirosian Far East establishes a complex representation of East-West relations that is not restricted to the crystallized images found in the Portuguese literature, which highlight exoticism and an imaginary character. As our main theoretical framework, we use Orientalist theories, especially those of Raymond Schwab (1950) and Edward Said (1978), and critical texts on Eça's works. We perform a comparative analysis of fictional and non-fictional texts of the writer, which includes the novels $O$ Mistério da Estrada de Sintra (1870), jointly written with Ramalho Ortigão, O Mandarim (1880) and A Correspondência de Fradique Mendes (1900); the journalistic texts “A Marinha e a Colônia” (1871), "A Pitoresca História da Revolta da Índia” (1871), “A França e o Sião" (1893), "Chineses e Japoneses” (1894), “A Propósito da Doutrina Monroe e do Nativismo" (1896), "França e Sião" (1897); and the consular report A Emigração como Força Civilizadora (1979).
\end{abstract}

Keywords: Eça de Queirós; Far East; Literary Orientalism; 19th Century. 


\section{SUMÁRIO}

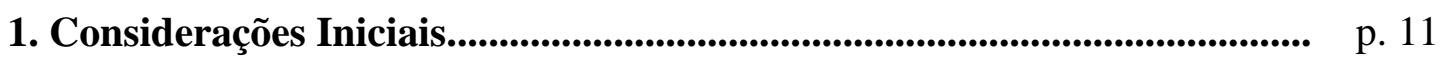

1.1. Principais Teorias Orientalistas..................................................... p. 17

1.2. Orientalismo Literário Português...................................................... p. p. 24

1.3. Os Orientes de Eça de Queirós....................................................... p. p. 38

2. O Extremo Oriente nas Obras Não Ficcionais de Eça de Queirós........... p. p. 48

2.1. O Extremo-Oriente em A Emigração como Força Civilizadora........ p. p 49

2.2. O Extremo-Oriente em Uma Campanha Alegre (Textos d'As

Farpas) ................................................................................... p. 57

2.3. O Extremo-Oriente em Ecos de Paris e Cartas Familiares e

Bilhetes de Paris (Textos à Gazeta de Notícias do Rio de Janeiro)........... p. 67

2.3.1. A França e o Sião............................................................................ p. 69

2.3.2. Chineses e Japoneses .............................................................. p. 76

2.3.3. A Propósito da Doutrina Monroe e do Nativismo.......................... p. 89

2.4. O Extremo-Oriente na Revista Moderna - "França e Sião".............. p. p. 95

2.5. Conclusão Parcial...................................................................... p. p 105

3. O Extremo Oriente nas Obras Ficcionais de Eça de Queirós..................... p. p. 108

3.1. O Extremo Oriente em O Mistério da Estrada de Sintra.................. p. p. 118

3.2. O Extremo Oriente em $O$ Mandarim............................................. p. 131

3.2.1. Estudos acerca da China de $O$ Mandarim................................... p. p. 133

3.2.2. As representações da China em $O$ Mandarim e o (não) diálogo entre Ocidente e Oriente.................................................................... p. p. 152

3.3. O Extremo Oriente em A Correspondência de Fradique Mendes...... p. 171

3.4. Conclusão Parcial...................................................................... p. p. 201

4. Considerações Finais...................................................................................... p. 205

Referências bibliográficas.......................................................................... p. 210 
O céu da humanidade moderna está realmente estilhaçado pela ciclópica batalha de busca por riqueza e poder. $\mathrm{O}$ mundo tateia nas sombras do egoísmo e da vulgaridade. O conhecimento é comprado por má consciência, e a bondade é praticada a bem da utilidade. O Oriente e o Ocidente, como dois dragões lançados em mar tumultuado, em vão tentam reconquistar a joia da vida.

(Okakura Kakuzo (Tenshin), O livro do chá, p. 39) 


\section{CONSIDERAÇÕES INICIAIS}

A divisão do mundo em dois grandes blocos intitulados "Ocidente" e "Oriente" faz parte do senso comum. No entanto, deve-se ter em mente que esta divisão é uma segregação problemática, ainda mais nos dias atuais, em que vivemos em um mundo de fronteiras cada vez mais fluidas. Raymond Schwab, um dos teóricos dos estudos orientalistas, de quem falaremos mais detidamente adiante, afirma em seu livro La Renaissance Orientale (1950) que já o império romano, apropriando-se de uma herança helenista, divide o mundo entre "O mundo do 'nosso' e uma vaga Ásia"” (SCHWAB, 1950, p. 9, tradução nossa), aparecendo a palavra "Oriente", de acordo com o mesmo estudioso, pela primeira vez na Eneida de Virgílio. No entanto, se pensarmos que "Ocidente" e "Oriente" têm suas demarcações estabelecidas primariamente através de uma noção geográfica, na qual o "Ocidente" representaria originalmente a Europa e, posteriormente, a América do Norte, ou, de maneira mais genérica, aqueles que estão no lado oeste no mapa terrestre, enquanto o "Oriente" corresponderia ao continente asiático ou aqueles que estão a leste na cartografia ocidental ${ }^{2}$, percebemos sem profunda reflexão que a divisão geográfica é extremamente falha. Como encaixar dentro dessa divisão bipolar nações da Oceania como a Austrália e a Nova Zelândia, localizadas geograficamente no "Oriente", mas que se reconhecem como nações ocidentais e assim também são vistas por outros países? E a América Latina, que se entende como “Ocidente”, mas muitas vezes não é reconhecida como tal por Europa e América do Norte? Há também o caso da Rússia e da Turquia, localizadas parte no continente

\footnotetext{
1 "le monde du 'nôtre' et une vague Asie" (no original).

2 Ainda é valido destacar que essa divisão entre Oeste e Leste é baseada em um mapa formado por padrões eurocêntricos, onde a Europa e a África estão no centro, a Ásia à direita e o continente americano à esquerda. É preciso lembrar que não são todos os países que usam tais padrões cartográficos, a se destacar como exemplo o Japão e a Coréia do Sul.
} 
europeu, parte no continente asiático. A primeira procura ignorar vínculos tanto com europeus quanto com asiáticos, defendendo uma "independência cultural”. Já a segunda, apesar de fazer fronteira tanto com países europeus como a Bulgária e Grécia, como também com países asiáticos como Síria e Iraque, normalmente é encaixada mais próxima do "Oriente" que do "Ocidente". Ainda há de se destacar o caso interno do continente europeu, pois, se nações como França, Inglaterra, Itália e Alemanha são indiscutivelmente classificadas como "Ocidente", o mesmo não pode se dizer de países do Leste Europeu como Romênia, Bulgária, Polônia, entre outros ${ }^{3}$.

Embora muitas vezes o "Oriente" seja tratado como um bloco uno, também faz parte do senso comum uma subdivisão deste em outras duas regiões: o "Oriente Próximo" e o "Extremo Oriente". Edward Said, teórico palestino radicado nos Estados Unidos, de quem também trataremos ainda neste capítulo, relaciona essa nomenclatura à experiência europeia no "Oriente", sendo o "Oriente Próximo" aquele com que os europeus travaram relações por mais de mil anos, e o "Extremo Oriente" aquele com que os europeus tiveram menos contato e, portanto, conheciam menos (SAID, 2008, p. 46). Do ponto de vista geográfico, esta nomenclatura também, inicialmente, funcionaria, pois o "Oriente Próximo" seria a região "menos a leste" do continente asiático e o "Extremo Oriente" estaria "mais a leste" na cartografia eurocêntrica. No entanto, uma divisão geográfica do "Oriente Próximo" e do "Extremo Oriente" também é problemática, pois, por exemplo, o Egito, embora localizado no continente africano, é considerado como parte do "Oriente Próximo". Para justificar tal inclusão, poderíamos descartar, então, uma divisão geograficamente limitante e ponderarmos a religião como um divisor entre os "Orientes". Deste ponto de vista, o "Oriente Próximo" corresponderia às nações de maioria islâmica, e o "Extremo Oriente" compreenderia

\footnotetext{
${ }^{3}$ Tzvetan Todorov em $O$ homem desenraizado trabalha a questão de um "Ocidente" e um "não-Ocidente" dentro da própria Europa.
} 
nações de outras religiões, sendo as principais o Hinduísmo e o Budismo. Se tal critério, por um lado, resolve a questão de países como o Egito e a Turquia, por outro, gera novos problemas. Como encaixar então, Indonésia e Malásia, comumente compreendidas dentro do "Extremo Oriente", mas de maioria islâmica?

Adiantamos aqui que, cientes das limitações de tal divisão, em nosso trabalho vamos utilizar o fator religioso-cultural que acima descrevemos para estabelecer nossa divisão entre "Oriente Próximo" e "Extremo Oriente". Justificamos tal escolha, pois nosso objeto de estudo, a obra de Eça de Queirós (1845-1900), nos permite uma distinção clara do "Oriente" nesses dois blocos por tal pressuposto.

Como pudemos perceber pelas questões levantadas, a definição de "Oriente", seja ele "Próximo" ou "Extremo", e de "Ocidente" é controversa e problemática, pois não envolve critérios claramente definidos, nem espaços geográficos especificamente delimitados. Divisões tão vagas agregadas a outras questões como, por exemplo, políticas econômicas unilaterais, fizeram com que a relação Ocidente-Oriente nunca fosse simples, fato que se verifica ainda nos dias atuais.

Se esse contato entre um "Ocidente" e um "Oriente" vem desde a Antiguidade, conforme nos diz Schwab, será nos anos finais do século XVIII que a relação “Ocidente-Oriente” que ecoa ainda no princípio do século XXI se desenvolverá.

A empreitada imperialista de Napoleão, que invadiu o Egito em 1798, e a decifração dos hieróglifos egípcios por Champollion em 1824 farão com que se inicie uma série de pesquisas eruditas que se debruçam sobre as línguas, a história e as culturas do Oriente (LIMA, 1991, p. 20). Essa linha de estudos será denominada, ainda no século XIX como "orientalismo". No entanto, anteriormente, o Oriente, mais especificamente a China, já aparecia em diversos discursos do século XVIII. Iluministas como Voltaire (1694-1778) e Montesquieu (1689-1755) usavam um discurso 
"orientalista" "como artifício para propor novas ideias" (HESPANHA, 1999, p. 22). Uma visão idealizada em que a China aparecia como exemplo de racionalidade, organização política e religiosa foi bastante difundida pelos pensadores da Época das Luzes, como contraponto para a sociedade europeia que precisava se repensar. António Manuel Hespanha comenta que o interesse iluminista pela China não é genuíno. Tratase de um olhar da Europa à Europa, a fim de sustentar essa racionalidade nascente no pensamento do continente:

A cultura europeia voltara-se, de facto, sobre si própria, racionalizara as suas experiências de vida e transformara-as em padrões universais da Humanidade. O interesse pelo Oriente era, agora, o de encontrar lá uma prova da universalidade de princípios da racionalidade de cá. (HESPANHA, 1999, p. 23, grifo do autor).

Entretanto, já nos anos finais do século XVIII a imagem da China passa "de exemplo a contra exemplo" (HESPANHA, 1999, p. 23):

O "bom selvagem" e as antiguidades da Roma republicana começam a ser agora os exemplos civilizacionais mais na moda, ao passo que as descrições entusiásticas da China - que bebiam na agora suspeita fonte literária jesuíta - começam a ser denunciadas como panegíricos deformados. Enquanto a imagem da China imóvel e supersticiosamente conservadora se começa a instalar numa tradição intelectual que virá até aos nossos dias. Uma forma atenuada de etnocentrismo consiste na mera exoticização dos chineses (os 'chinesinhos'), cuja 'chinesice' se vai tornando um estereótipo ("engraçados", "pequenos", “diligentes", "pacientes", "incontáveis") (HESPANHA, 1999, p. 23).

Paralelamente ao interesse e ao desinteresse pela China, a intelectualidade europeia voltou sua atenção também ao sânscrito e a cultura hindu ${ }^{4}$. Ao longo do século XIX foram inauguradas várias sociedades culturais que se dedicavam aos estudos do Oriente, como Societé Asiatique, criada em 1822, a Royal Asiatic Society, fundada em 1823, e a American Oriental Society, em 1842. Portugal, devido a problemas internos que esclareceremos adiante, se viu tardiamente voltado aos estudos orientalistas. Conforme nos aponta Manuela Ramos, “os termos 'orientalismo' e 'sinologia'

\footnotetext{
${ }^{4}$ Cf. COUTO, 2011, p. 18.
} 
encontram-se pela primeira vez num dicionário português em 1873 , justamente o ano em que se reúne em Paris o I Congresso Internacional de Orientalistas" (RAMOS, 2001, p. 82). Guilherme de Vasconcelos Abreu (1842-1907) foi o inaugurador dos estudos orientalistas portugueses, se dedicando ao sânscrito, a cultura e as religiões da Índia. Em 1877, se tornou responsável pela recém-inaugurada cadeira de Língua e Literatura Sânscrita, Clássica e Védica, no Curso Superior de Letras de Lisboa. (RAMOS, 2001, p. $83)$.

No entanto, desde o princípio do século, França e Inglaterra, para nos atermos somente ao cenário europeu, já desenvolviam suas políticas imperialistas que se iniciaram com as expedições napoleônicas. Muitos estudos e discursos realizados a partir desses centros orientalistas visavam, então, referendar a intervenção europeia em outras sociedades tanto no plano econômico, quanto cultural. Cria-se assim a ideia amplamente difundida na Europa oitocentista de "civilizar" os outros povos, cristalizando-se, logo, a dicotomia "nós" (europeu, civilizado) e "eles" (oriental, bárbaro).

A partir deste fato, pode-se perceber que desde o final do século XVIII coexistiram dois discursos orientalistas: um positivo, em que se destaca uma valorização do pensamento e do modo de viver oriental em relação ao europeu; e um negativo, em que o oriental aparece como um selvagem que precisa ser "civilizado". Vale destacar que, em geral, ambos os discursos têm como centro a Europa, pois quando visto positivamente, o Oriente serve como fonte de novas ideias para reestruturar uma Europa sem imaginação e de ideias já gastas; quando visto negativamente, serve para corroborar a ideia euro e etnocêntrica de superioridade ocidental. Assim, ambos os discursos recaem sobre uma leitura superficial e baseada em 
estereótipos, ratificando a já clássica noção desta área de estudos que o discurso orientalista revela mais de seu enunciador do que de seu enunciado.

Tais discursos influenciaram diretamente a produção artística europeia. Durante todo o século XIX pintura, arquitetura, decoração de interiores, música e literatura se viram influenciados pelo Oriente, ou melhor, pelo orientalismo. Objetos oriundos do Oriente se tornaram sinônimo de requinte e fineza e criou-se, por exemplo, na decoração uma moda da chinoiserie, "gosto pelos temas chineses [...] importado, sobretudo da decoração rocaille, cujos decorativismo, "leveza" e "delicadeza" se casam bem com os novos estereótipos estéticos ou intelectuais sobre a cultura chinesa" (HESPANHA, 1999, p. 25). Ainda, pode-se falar em outras tendências nas artes como um "japonismo" na pintura e literatura.

Paralelamente, com a Revolução Industrial, a propagação dos caminhos de ferro e viagens a navio mais seguras, desenvolveu-se o turismo. Viagens ao Oriente passaram a fazer parte dos planos da elite europeia e a busca por ser cosmopolita, conhecedor de diversas culturas e "cidadão do mundo", se tornou o objetivo de muitos intelectuais europeus. Assim, proliferaram nessa época inúmeras obras da "literatura de viagem". As experiências de viagem e a busca por este cosmopolitismo se tornaram influências importantes para a constituição de obras do romantismo e do realismo francês, inglês e alemão.

A presença marcante do orientalismo no cotidiano europeu, principalmente do século XIX, e o pós-colonialismo do século passado fizeram com que, na segunda metade século XX, se desenvolvessem algumas teorias orientalistas. Destacam-se estudos como os de Raymond Schwab (1950), Edward Said (1978) e, mais contemporaneamente, John Mackenzie (1995), Aijaz Ahmad (década de 1990), entre

\footnotetext{
${ }^{5}$ Cf. KUNIYOSHI, 1998, p. 73-90 e DANTAS, 2010, p. 184-206.
} 
outros. Antes de avançarmos no nosso estudo, vale passar por algumas das principais teorias, pois estas serão fundamentais para a compreensão de nossa análise.

\subsection{PRINCIPAIS TEORIAS ORIENTALISTAS}

Apesar das principais teorias orientalistas terem se desenvolvido na segunda metade do século XX, a primeira delas data do século XIX. Em 1841, Edgar Quinet (1803-1875), intelectual francês especialista em história alemã, escreveu Génie des Religions, obra em que dedicou um capítulo ao orientalismo. Neste capítulo, intitulado "De la Renaissance Orientale", Quinet trata desde os primeiros registros do Oriente na literatura europeia, dando especial atenção à Bíblia, "o livro mais ocidental do Oriente ${ }^{6 "}$ (QUINET, 2003, p. 18, tradução nossa). Aborda também a viagem de Marco Polo ao Oriente no século XV e a transposição do Cabo da Boa Esperança como fatos marcantes para a retomada de um contato "perdido" entre Oriente e Ocidente (QUINET, 2003, p. 22). Adentrando o campo da literatura, Quinet diz que Os Lusíadas (1572) de Camões $(1524 / 5$ ? - 1580) é a primeira obra literária a fazer "a aliança do Oriente e do Ocidente" (QUINET, 2003, p. 35, tradução nossa). Deste ponto de vista, Quinet confere a $O s$ Lusíadas o status de primeira obra literária orientalista do Ocidente. Fazendo uma comparação entre o poema épico camoniano e a Odisséia de Homero, Quinet diz:

o poema que abre com o século XVI, a era dos tempos modernos, é aquele que selando a aliança do Oriente e do Ocidente celebra a idade heroica da indústria, poema não mais do peregrino, mas do viajante, sobretudo do comerciante, autêntica Odisseia em meio às feitorias nascentes das Grandes Índias e do berço do comércio moderno, do mesmo modo que a Odisseia de Homero é uma viagem através dos berços das pequenas sociedades militares e artísticas da Grécia ${ }^{8}$ (QUINET, 2003, p. 35, tradução nossa).

\footnotetext{
6 "le livre le plus occidental de l'Orient" (no original).

7 "l'alliance d'Orient et de l'Occident" (no original).

8 “le poème qui ouvre avec le seizième siècle l'ère des temps modernes, est celui qui, en scellant l'alliance de l'Orient et de l'Occident célèbre l'âge heroique de l'industrie, poème non plus pèlerin, mais du voyageur, surtout du commerçant, véritable Odyssée au milieu des factoreries, des comptoirs naissants
} 
Deste modo, Quinet reflete sobre o século XVIII e XIX, estudando a influência do Oriente na Alemanha, dando especial atenção aos textos de Herder (1744-1803) e Goethe (1749-1822). De um modo geral, Edgar Quinet se propõe a expor como a influência do Oriente se deu de maneira positiva e especial não só no pensamento desses autores, mas principalmente na intelectualidade europeia como um todo, podendo ser considerada, como uma segunda renascença no pensamento europeu, ou, como o próprio título do texto diz, uma "Renascença Oriental".

Um pouco mais de um século mais tarde, Raymond Schwab vai desenvolver a ideia que Quinet proferira. Schwab inclusive se inspira no título do texto de Quinet para escrever o seu La Renaissance Orientale, obra que defende um "humanismo oriental"". O teórico parte de estudos a partir do século XVIII para mostrar extensivamente a influência positiva que o pensamento oriental - em especial o indiano e, em menor grau, o chinês - proporcionou à intelectualidade europeia.

Para Schwab, o Oriente, este "humanismo oriental" ou esta "renascença oriental" significa [...] a renovação de atmosfera produzida no século XIX pela chegada dos textos sânscritos na Europa, elucida e coloca-se em igualdade àquela ocorrida no século $\mathrm{XV}$, com a chegada dos manuscritos gregos e dos comentaristas bizantinos após a queda de Constantinopla $^{10}$ (SCHWAB, 1950, p. 18, tradução nossa).

Schwab também faz um histórico mais detalhado que Quinet das relações entre Ocidente e Oriente, em que atribui o início da "Renascença Oriental" à decifração das formas de escritas até então desconhecidas da Europa. Assim os estudos acerca dos hieróglifos egípcios por Champollion e dos ideogramas chineses por Rémusat

des Grandes Indes et du berceau du commerce moderne, de même que l'Odyssée d'Homère est un voyage à travers les berceaux des petites sociétés militaires et artistes de la Grèce" (no original).

${ }^{9}$ Manuela Ramos diz: "Em 1948, no Congresso Internacional de Orientalistas, Schwab propõe a criação de um comité do 'humanismo oriental' com o objetivo primordial de preparar uma história geral do orientalismo. Passados dois anos é ele próprio que apresenta essa obra, La Renaissance Orientale" (RAMOS, 2001, p. 17).

10 "signifie [...] le renouvellement d'atmosphère produits au XIXe siècle par l'arrivée des textes sancrits en Europe, on l'èclaire en le mettant à égalité avec celui qu'avait opéré au XVe siécle, l'arrivée des manuscrits grecs et des commentateurs byzantins, après la prise de Constantinople" (no original). 
(SCHWAB, 1950, p. 19) fizeram com que a Europa percebesse que "não era a única proprietária de um admirável passado intelectual ${ }^{11 "}$ (SCHWAB, 1950, p. 7, tradução nossa). Schwab destaca a imprecisão geográfica na definição de "Oriente" e defende que a "renascença oriental" proporcionou a quebra da barreira que, segundo ele, dividia o mundo em dois blocos (SCHWAB, 1950, p. 9).

Estas ideias de uma influência positiva oriental na intelectualidade europeia, na qual esta pode aprender e reformular seu modo de pensar com o Oriente, já estão expostas nas primeiras páginas de sua obra e permeiam todo seu extenso estudo. No desenrolar de seu livro, Schwab trata ainda de questões como a religião cristã e hindu, pessoas que pensaram o orientalismo e analisa o Oriente, especialmente a Índia, na obra de alguns artistas e pensadores europeus - principalmente franceses e alemães - como Gérard de Nerval (1808-1855), Gustave Flaubert (1821-1880), Theóphile Gautier (1811-1872), Victor Hugo (1802-1885), Jules Michelet (1798-1874), Alphonse de Lamartine (1790-1869), Arthur Schopenhauer (1788-1860), Friedrich Nietzsche (18441900) e Richard Wagner (1813-1873).

Se Schwab usa da análise literária, entre outras estratégias, para defender seu ponto de vista, o mesmo será feito por Edward Said, vinte e oito anos depois. Edward Said, palestino que viveu no Egito antes de emigrar aos Estados Unidos onde estudou e desenvolveu sua carreira acadêmica, escreveu em 1978 seu mais famoso livro, Orientalismo. Esses dados biográficos são importantes, pois, como bem destaca Manuela Ramos (2001, p. 21) é como “sujeito oriental” que Said escreve. Deste ponto de vista, seu texto representaria algo inédito, pois não seria um "ocidental", mas um “oriental" falando. Hoje, esta perspectiva de "sujeito oriental” é relativizada, pois, como recorda Érika Horigoshi (2012, p. 18), Said recebeu larga influência do Ocidente em sua

\footnotetext{
11 “n'était pas seul titulaire d'un admirable passé intellectuel” (no original).
} 
formação intelectual e no desenvolvimento de suas teorias. Said conhece e em alguns momentos comenta, nem sempre positivamente, as obras de Quinet e Schwab ${ }^{12}$, pois seu objetivo é exatamente o oposto. Quando publicado, Orientalismo

foi recebido como um livro de conteúdo sem precedentes, pois, pela primeira vez, um autor fazia um levantamento de posições e de atitudes histórico-políticas que denotavam a representação inventada do Oriente por parte do Ocidente e criticava abertamente a suposta superioridade ocidental, oferecendo bases para a continuidade de um processo de questionamento desse padrão arraigado de ideias e de ideais. (HORIGOSHI, 2012, p. 17).

O grande propósito de Said com essa obra é demonstrar como o Oriente é "uma invenção europeia e fora [assim] desde a Antiguidade" (SAID, 2008, p. 27), além de como o discurso euro-americano serviu como aparato para se criar uma imagem de um Ocidente "superior" e de um Oriente "inferior". O ineditismo da obra de Said está justamente no fato de desvendar essa faceta negativa dos estudos orientalistas. Said claramente afirma que "o Orientalismo expressa e representa essa parte [o Oriente] em termos culturais e mesmo ideológicos num modo de discurso baseado em instituições, vocabulário, erudição, imagens, doutrinas, burocracias e estilos coloniais” (SAID, 2008, p. 28), sendo assim um discurso que visa reforçar as ações colonialistas e imperialistas ocidentais. Said, enquanto "sujeito palestino", se preocupa majoritariamente em seu texto com as imagens do arabismo e do islamismo. Pouco trata da China, Índia ou de outras regiões classificadas como Extremo Oriente. Said, assim como Schwab, se utiliza da análise de textos para defender sua tese. Assim percorre inúmeras obras da literatura europeia, desde a Divina Comédia de Dante Alighieri (1265-1321) a textos do século XIX, englobando também textos não literários como os de Ernest Renan (1823-1892) e

\footnotetext{
${ }^{12}$ Assim como acontece com Quinet, são vários os momentos que Said se refere à obra de Schwab. Destacamos o trecho: "Pela metade do século XIX, o Orientalismo era o mais vasto tesouro de erudição que se poderia imaginar. Há duas excelentes indicações desse novo e triunfante ecletismo. Uma é a descrição enciclopédica do Orientalismo [...] apresentada por Raymond Schwab no seu La Renaissance Orientale. [...] A noção de Schwab é que "oriental" identifica um entusiasmo profissional ou amador por qualquer coisa asiática, que era um sinônimo maravilhoso para o exótico, o misterioso, o profundo, o seminal; é uma transposição tardia para o Leste de um entusiasmo semelhante na Europa pela antiguidade grega e latina durante a Alta Renascença" (SAID, 2008, p. 87).
} 
a Teoria Evolucionista de Charles Darwin (1809-1882). Embora original, a teoria de Said não deixa de ter suas limitações. A quase exclusividade dada às imagens do islamismo em seu estudo faz com que ele atribua, em muitos momentos, uma imagem una da intervenção europeia no Oriente Próximo e no Extremo Oriente, destacando assim um "orientalismo árabe” ou, mais precisamente, um "orientalismo islâmico", mas ignorando possíveis peculiaridades existentes de um "orientalismo chinês", um “orientalismo japonês”, e assim por diante. Ainda, Manuela Ramos (2001, p. 27) destaca que a insistência de Said em revelar o "lado negro" das atividades europeias no Oriente acabam por fazê-lo passar superficialmente por aqueles europeus que procuravam aprender com as culturas orientais. Ou seja, Said de certo modo diminui a empreitada desses estudiosos, arrumando "em três linhas o desenvolvimento positivo do orientalismo" (RAMOS, 2001, p. 27).

As ideias de Said se tornaram tão difundidas que o termo "orientalismo" se tornou sinônimo da visão saidiana do assunto. Em outras palavras, não seria exagero dizer que se nos propuséssemos a fazer uma análise de um discurso orientalista sem esclarecer o que entendemos por "orientalismo", tomar-se-ia por pressuposto a concepção saidiana do termo. Não vai ser por acaso que John Mackenzie, em seu livro Orientalism. History, theory and the arts (1995), "responsabiliza Edward Said pelo facto do termo orientalismo ter adquirido uma conotação negativa" (RAMOS, 2001, p. 18).

Aqui, em nosso trabalho, vamos usar tanto o trabalho de Schwab quanto o de Said como referências. Não acreditamos que as obras de Eça de Queirós, nosso objeto de estudo, possam ser ancoradas exclusivamente em uma visão ou em outra sem que, com isso, tenhamos uma leitura parcial dos textos. Assim, ao utilizarmos o termo “orientalismo", deve-se interpretá-lo por seu sentido mais básico: o de um discurso ou 
uma ideia sobre um Oriente a partir de um enunciador ocidental, mais especificamente, europeu. Aproximaremos os textos analisados a uma ou a outra teoria à medida que julgarmos necessário ou enriquecedor para a compreensão de nossa análise.

A escolha dos textos de Schwab e Said como principais pressupostos teóricos não é, obviamente, aleatória. Ambos foram pioneiros ao revelar dois lados de um mesmo assunto: o orientalismo, isto é, o discurso e as representações do Ocidente sobre o Oriente. Embora Schwab tenha feito seu estudo a partir do capítulo escrito por Quinet, ele desenvolve longamente a ideia da "renascença oriental", acrescentando profundidade ao tema. Ambos ainda se utilizam de estratégias próximas para atingir seu objetivo, não esquecendo a grande erudição demonstrada pelos dois teóricos. Contudo, as teorias não se encerram a estes dois nomes. Se o texto de Schwab muitas vezes não é lembrado nos estudos orientalistas atuais, a teoria saidiana, ao contrário, é incontornável. No entanto, não é absoluta e, como dissemos, não deixa de ter suas limitações. Uma vez que ela cristalizou o viés negativo da representação oriental pelo Ocidente, estudiosos pós-saidianos tem se dedicado a relativizar a negatividade que o termo assumiu, reconsiderando alguns pontos positivos, sem cair no "enciclopedismo" que Said acusa a obra de Schwab. Por exemplo, John Mackenzie, no já citado Orientalism. History, theory and the arts; Aijaz Ahmad, em "Orientalismo e depois: Ambivalência e posição metropolitana na obra de Edward Said" (2002); entre outros fazem cuidadosas leituras do texto saidiano, criticando muitas de suas posturas. Ahmad, por exemplo, diz sobre a obra de Said:

A textura específica de Orientalismo, sua ênfase nos textos canônicos, seu privilegiamento da literatura e da filologia na constituição do conhecimento "orientalista" e mesmo das ciências humanas em geral, sua vontade de retratar um "Ocidente" que é o mesmo desde a aurora da história até o presente, e sua vontade de percorrer todas as principais línguas da Europa - tudo isso, e mais, em Orientalismo deriva da ambição de escrever uma contra-história que pudesse ser colocada contra Mimesis, a exposição magistral de Auerbach da gênese inconsútil do realismo e do racionalismo europeus desde a 
Antiguidade grega até o momento modernista (AHMAD, 2002, p. 113).

Quanto a questão de Said se auto apresentar como "sujeito oriental", aspecto que já nos referimos, Ahmad diz:

essas auto-representações são sempre um tanto unilaterais, portanto, um tanto arriscadas [...]. Qualquer leitura cuidadosa de toda a sua obra mostraria quão estrategicamente ele usa palavras como "nós" e "nos", para se referir em contextos variados, a palestinos, a intelectuais do Terceiro Mundo, a acadêmicos em geral, a humanistas, árabes, árabesamericanos e a cidadãos norte-americanos em geral (AHMAD, 2002, p. 121, grifo do autor).

É válido ressaltar que, diante da repercussão de seu texto, Said elabora um artigo intitulado "O orientalismo reconsiderado" (2003). O teórico palestino diz que seu artigo não "se trata de uma tentativa de responder aos meus críticos", mas sim uma possibilidade de "aprofundar um argumento" (SAID, 2003, p. 61). Neste artigo o autor de Orientalismo visa justificar alguns dos "limites de seu texto", como, por exemplo, o fato de não tratar do "desenvolvimento positivo do orientalismo" (RAMOS, 2001, p. 27):

A partir do final do século XVIII, quando o Oriente foi redescoberto pela Europa, sua história foi um paradigma de antiguidade e originalidade, funções que atraíam os interesses da Europa, em atos de reconhecimento e agradecimento, mas das quais a Europa se afastou à medida que seu desenvolvimento industrial, econômico e cultural parecia deixar o Oriente para trás. Para Hegel, Marx e depois Burkhardt, Nietzsche, Spengler e outros importantes filósofos, a história oriental era útil para retratar uma região muito idosa e o que tinha de ser posto de lado. (SAID, 2003, p. 65).

Pelo que se pode verificar, Said, neste artigo, procura reforçar sua ideia e suas escolhas feitas não só, mas principalmente, no livro de 1978.

Vê-se, então, que, assim como toda a relação entre Oriente-Ocidente, a discussão teórica sobre orientalismo não é simples, nem conclusiva. Nos dias atuais, esse debate se encontra em desenvolvimento, tendo quase sempre, devido ao grande impacto que o Orientalismo causou nos estudos orientalistas, o pensamento saidiano como referência positiva ou negativa. 
Conforme comentamos, seja por um viés positivo, seja por um negativo, fato é que o Oriente, no século XIX, se tornou presente nas artes europeias. O romantismo francês, inglês e alemão, por exemplo, tiveram nas alusões orientais elementos fundamentais da sua constituição ${ }^{13}$. E na literatura portuguesa? Para entendermos como a literatura lusitana se utilizou de tais referências e para podermos entender onde Eça de Queirós se encaixa dentro desse quadro, nos propormos a remontar rapidamente um panorama do orientalismo literário português, desde o século XVI até as primeiras décadas do século XX.

\subsection{ORIENTALISMO LITERÁRIO PORTUGUÊS}

As representações do Oriente na literatura portuguesa se dão de maneira um pouco distinta do restante da literatura europeia. Deve-se levar em conta que a relação de Portugal com essa região do globo é especial, principalmente pelo fato de o período em que Portugal esteve entre as grandes nações do mundo, ou seja, a época das Grandes Navegações - época constantemente retomada em sua literatura de todos os períodos que se seguiram - estar diretamente ligada à chegada às Índias e o estabelecimento de colônias portuguesas no Oriente. Diz António Manuel Hespanha:

A história portuguesa - e mais ainda, a sua vulgata escolar - está cheia de gestas orientais ligadas às épocas de esplendor de Portugal, como se Portugal quando não esteve no Oriente, tivesse estado na miséria e na mesquinhez. [...] Foi no Oriente que se fizeram nossos santos e os nossos heróis. A "nossa" Goa foi a Roma do Oriente e o Padroado Português foi o "do Oriente", também. Foi no Oriente que o nosso Império começou e é nele que, em 1999, ele irá acabar (HESPANHA, 1999, p. 15).

\footnotetext{
${ }^{13}$ É extensa a lista de autores que refletem o orientalismo em sua obra. Para citar apenas alguns, temos Flaubert (1821-1880), Nerval (1808-1855), Chateaubriand (1768-1848), Lamartine (1790-1869), Vigny (1797-1863) e Hugo (1802-1885), na França; Byron (1788-1824) e Thomas Moore (1779-1852), no Reino Unido; na Alemanha, entre tantos outros, Herder (1744-1803) e Goethe (1749-1822).
} 
Assim, as primeiras aparições do Oriente na literatura portuguesa datam do século XVI. Nas crônicas de viagens quinhentistas aparecem diversos textos que retratam costumes, culturas e paisagens. Textos de historiadores levados pela "passional curiosidade humanista" (MACHADO, 1983, p. 19) deste século também vão transmitir impressões das terras recém aportadas. Álvaro Manuel Machado em O Mito do Oriente na Literatura Portuguesa (1983) destaca quatro nomes desse período: Damião de Góis (1502-1574); João de Barros (1496?-1570 ou 1571); Diogo de Couto (1542-1616) e Fernão Mendes Pinto $(1510 ?-1583)^{14}$.

O Oriente nos textos desses autores aparece de forma heterogênea. Por exemplo, de Damião de Góis, diz Machado: "Damião de Góis é o cosmopolita típico do nosso século XVI, europeu voltado para todas as civilizações” (MACHADO, 1983, p. 20), assim "Damião de Góis só se interessa pelo Oriente de maneira episódica" (MACHADO, 1983, p. 22). No entanto, acrescenta que

o seu cosmopolitismo, além de se integrar, certamente mais do que o de qualquer outra personalidade portuguesa da época, no conjunto do movimento humanista europeu, o levou a interessar-se concretamente por civilizações não ocidentais. Concretamente significa aqui conhecer in loco, viajando (MACHADO, 1983, p. 21, grifo do autor).

Tal "cosmopolitismo" acaba sendo fatal para Damião de Góis pois "marcado pelas ideias 'estrangeiradas', acabou perseguido pela Inquisição, vindo a ser preso, em 1571, e morrendo na prisão" (MACHADO, 1983, p. 21).

Já João de Barros se dedica de maneira mais centrada ao Oriente em seus textos históricos denominados Décadas. Segundo Machado, o historiador "concentra na evocação da descoberta e conquista e na descrição minuciosa das terras orientais o essencial quer da sua pesquisa de historiador quer da sua arte clássica" (MACHADO,

\footnotetext{
${ }^{14}$ Todas as referências de nascimento e morte foram tiradas do Dicionário de Literatura Portuguesa, organizado por Álvaro Manuel Machado (1996), publicado pela Editora Presença em Lisboa, exceto o de Luís de Camões, retirado do Dicionário de Luís de Camões (2011), coordenado por Vítor Aguiar e Silva e publicado, no Brasil, pela editora Leya.
} 
1983, p. 22). No entanto, vale destacar que João de Barros nunca foi ao Oriente. Ou seja, diferentemente de Damião de Góis, ele não teve a experiência in loco, a substituindo "por uma elaborada retórica clássica evocativa do longínquo” (MACHADO, 1983, p. 22). João de Barros acaba sendo classificado por este estudioso como um "humanista estático pouco ou nada viajado" (MACHADO, 1983, p. 25), que "transfere para a palavra, mais propriamente, para a fixidez da palavra a partir da aprendizagem clássica, a sua fascinação pelo longínquo desconhecido" (MACHADO, 1983, p. 25).

Diogo de Couto partiu ainda jovem para as colônias portuguesas onde lutou e, posteriormente, se fixou em Goa. Conviveu com Camões, de quem falaremos adiante, e também escreveu algumas Décadas, em que transmitiu suas impressões das possessões portuguesas no Oriente. Assim, o Oriente de Diogo de Couto é principalmente a Índia portuguesa. Álvaro Manuel Machado destaca que a Índia retratada nas crônicas de Couto é "uma Índia tornada paraíso perdido dos descobrimentos e conquistas orientais dos portugueses em progressiva e fatal decadência" (MACHADO, 1983, p. 31). Essa decadência expressa nas crônicas de Couto representa, de acordo com o estudioso, um cuidado "em apontar racionalmente erros de governação mais do que exprimir mítica nostalgia do passado" (MACHADO, 1983, p. 33). Deste ponto de vista, Diogo de Couto se faz preocupado com a política colonial imposta pelo reinado português, atentando para a situação econômica, militar, religiosa, social e moral dos portugueses na Índia. No entanto, Machado aponta uma contradição nos textos de Couto. Segundo este estudioso, à parte dessa visão crítica das colônias, o humanista português "acaba por encadear um delírio passadista de caráter puramente mítico" (MACHADO, 1983, p. 33). Assim existem em seus textos duas Índias: uma Índia do passado e outra do presente.

Das crônicas quinhentistas que versam sobre o Oriente, a mais renomada é, no entanto, a Peregrinação de Fernão Mendes Pinto. Álvaro Manuel Machado o define 
como "um viandante, um peregrino e um aventureiro perdido no mundo oriental, para onde embarca em 1537; um típico anti-herói picaresco" (MACHADO, 1983, p. 40). Nesta obra descreve terras como a Índia, a China e o Japão onde se contrasta, de acordo com o estudioso português que temos citado, "uma visão utópica do Oriente em geral" (MACHADO, 1983, p. 42) com "lições de civilização a Portugal” (MACHADO, 1983, p. 42). É estabelecido pela crítica um afastamento das crônicas de Fernão Mendes Pinto com as de Damião Góis, João de Barros e Diogo de Couto, pois se estas, de um modo ou de outro, representavam apologias da expansão portuguesa no Oriente, a obra de Pinto põe "em causa a própria ideia de uma civilização ocidental expandindo-se através das descobertas e conquistas dos portugueses" (MACHADO, 1983, p. 41) ${ }^{15}$. Deste modo ele enxergaria no Oriente civilizações, não selvagens. A partir deste ponto de vista, Álvaro Manuel Machado vê Fernão Mendes Pinto como uma espécie de precursor de um orientalismo exótico descritivo predominante no século XIX (MACHADO, 1983, p. 44). Assim, mesmo que cronologicamente próximos, os textos de Fernão Mendes Pinto e o dos outros cronistas citados estariam literariamente distantes.

O Oriente também foi representado na poesia quinhentista portuguesa na pena de Camões (1524/5?-1580). Como já citamos anteriormente, Edgar Quinet considera Os Lusíadas como a primeira obra orientalista da literatura ocidental. No entanto, além da famosa poesia épica de Camões, que, entre outros lugares, conheceu Macau e o Sudeste Asiático, o Oriente também aparece em sua poesia lírica. Como ilustração, citamos novamente a leitura feira por Álvaro Manuel Machado. Para este estudioso, enquanto n'Os Lusíadas o Oriente "serve apenas para reforçar a mitologia nacionalista" (MACHADO, 1983, p. 49), na sua poesia lírica “as imagens do Oriente [...] tornam-se arquetípicas, não correspondendo diretamente à realidade física, histórica e geográfica,

\footnotetext{
15 Álvaro Manuel Machado (1983, p. 41) cita António José Saraiva que em seu estudo sobre Peregrinação (1961) também nota tal fato.
} 
embora sejam desencadeadas por elas, antes correspondendo a uma transfiguração simbólica que mitifica esses lugares" (MACHADO, 1983, p. 51). Machado ainda destaca dois aspectos do Oriente na poesia lírica camoniana: um tom confessional, chamado por Machado de "confessionalismo barroco, ou mais exactamente, barroquizante" (MACHADO, 1983, p. 53); e o Oriente como uma terra "símbolo de uma fascinação maldita, obscura, indeterminada, digamos até infernal” (MACHADO, 1983, p. 55).

A crítica aponta um hiato de representações do Oriente na literatura portuguesa desde o começo do século XVII até a segunda metade do século XIX, tendo por exceção a poesia de Bocage (1765-1805). Destaca-se a semelhança da representação do Oriente de Camões com a de Bocage, enfatizando os aspectos confessionais e a mitologia nacionalista. Tal associação acontece, sobretudo, pelo fato de o próprio poeta setecentista se comparar ao quinhentista ${ }^{16}$, principalmente nos aspectos biográficos, como as viagens ao Oriente e a sensação de exílio que essas viagens proporcionam.

No entanto, vale ressaltar que se ao longo desses dois séculos e meio o Oriente não se faz presente nas obras canônicas da literatura portuguesa, aparece nos textos escritos por missionários religiosos em terras orientais. Ou seja, não se pode afirmar que o Oriente esteve completamente ausente dos escritos portugueses desta época. Se não aparece com relevância em poesias ou peças teatrais, se faz presente, ao menos, na literatura produzida por jesuítas. Se lembrarmos que o projeto missionário foi um dos modos mais marcantes da presença portuguesa nas civilizações orientais, vemos que as produções escritas ao longo desses períodos foram, como indica Hespanha, o verdadeiro saber colonial português, pois era necessário "conhecer as religiões orientais, de dominar as línguas, de conhecer costumes e mentalidades, de aprender as

\footnotetext{
${ }^{16}$ Cf. o famoso poema de Bocage "Camões, grande Camões quão semelhante / Acho o teu fado ao meu, quando os cotejo!...”
} 
particularidades finas da política local, de conhecer superficialmente o espaço para nele implantar a fina quadrícula da administração eclesiástica" (HESPANHA, 1999, p. 19). Em suma, mesmo que com a finalidade de "conhecer para catequizar", impressões do Oriente e suas culturas foram produzidas em língua portuguesa ao longo dos séculos XVII e XVIII também, mesmo que em obras de valor mais antropológico que literário.

A primeira metade do século XIX também apresentou poucas representações orientais em suas produções literárias. Recordando rapidamente alguns fatos já expostos, a revolução industrial do final do século XVIII, o desenvolvimento do motor a vapor e a expansão das linhas ferroviárias permitiram que as viagens internacionais se tornassem mais rápidas e seguras, fazendo com que se iniciassem as viagens turísticas a diversas regiões do mundo, inclusive ao Oriente. Deste modo no início do século XIX houve uma espécie de "redescoberta" do Oriente pelo Ocidente. Assim, o interesse pelas culturas orientais cresceu rapidamente e o Oriente voltou a estar em voga na literatura europeia, a se destacar a francesa, a inglesa e a alemã. No entanto, este é um período delicado para Portugal, que foi vítima das invasões napoleônicas em 1807, seguindo-se a Revolução Liberal em 1820 e a guerra civil. Perdeu ainda sua principal colônia, o Brasil, que era sua principal fonte de recursos. Nas relações internacionais a relação com a Inglaterra também se torna conturbada ${ }^{17}$. Devido a todos esses fatos, os intelectuais portugueses terão sua atenção voltada aos acontecimentos europeus. Nas palavras de António Manuel Hespanha: “A própria situação política metropolitana provocava um centramento da atenção sobre os problemas europeus" (HESPANHA, 1999, p. 26). Não é o caso de excluir totalmente representações orientais na primeira metade dos oitocentos, mas, diz Isabel Pires de Lima: "quando o Oriente pontualmente nela [na literatura romântica] emerge é como representação da ideia de exílio mais até

\footnotetext{
${ }^{17}$ Cf. o capítulo X da obra de OLIVEIRA MARQUES, 1983.
} 
do que como espaço físico de viagem mítica ou real" (LIMA, 1999, p. 148). Ainda, de acordo com a mesma estudiosa, o Oriente só será representado na literatura romântica de maneira tardia:

Só tardiamente alguns remanescentes românticos manifestam um certo gosto difuso pelos ambientes orientais e sobretudo pelo Oriente nacionalista mítico e heroico: são os casos do oficial da marinha Francisco Maria Bordalo, autor do romance histórico Sansão na Vingança! (1854); do médico e deputado goês Francisco Luís Gomes, que publicou um dos primeiros romances de ambiente indiano na Europa, Os Brahamanes (1866); de Tomás Ribeiro, que para além de textos em prosa intitulados Jornadas e da peça A Indiana (ambos de 1873), escreveu poesia de inspiração orientalista, Vésperas (1880); de Pinheiro Chagas, que situa em Goa o seu romance de intriga romântica, A Marquesa das Índias (1890), e será autor de diversos romances históricos que narram viagens à Índia; de Henrique Lopes Mendonça, com a publicação do romance histórico, Os Órfãos de Calecut (1894); do profícuo Campos Júnior, o qual, na onda dos romances históricos glorificadores da viagem de Vasco da Gama, por ocasião das comemorações do IV Centenário, publica, em 1898, Guerreiro e Monge (a par de Artur Lobo de Ávila, com A Descoberta e Conquista da Índia e de Lourenço Cayolla, com $O$ Despertar de um Sonho), e mais tarde, Luís de Camões (1901), A Estrela de Nagasáqui (1907), Santa Pátria (?); ou o caso mais tardio ainda de Eduardo Noronha, que dá a lume, em 1927, um romance sobre a vida de S. Francisco Xavier, O Missionário (LIMA, 1999, p. 148-149).

Afirma, então, a estudiosa que "será preciso esperar pela Geração de 70 para que o Oriente adquira matizes originais e significativos na literatura portuguesa oitocentista" (LIMA, 1999, p. 149). António Manuel Hespanha compartilha da mesma visão, pois afirma que "os românticos portugueses procuraram o pitoresco, não no exotismo, mas nos tipos medievais ou populares. É preciso esperar por Eça de Queiróz para encontrarmos referência ao Oriente" (HESPANHA, 1999, p. 26). Monica Simas também defende esta ideia ao afirmar que a Geração de 70 concede ao Oriente "novos contornos" (SIMAS, 2007, p. 92) na literatura portuguesa. Assim, seja numa literatura romântica tardia, conforme podemos depreender pelas datas das obras apresentadas no levantamento de Isabel Pires de Lima, seja na literatura da geração que quebra com a corrente romântica, ou seja, a da Geração de 70 - principalmente nas figuras de Antero de Quental (1842-1891) e de Eça de Queirós, de quem falaremos mais detalhadamente 
no próximo item, mas também em textos de Oliveira Martins (1845-1894) e em poemas de Gomes Leal (1848-1921), entre outros - o Oriente se faz marcadamente presente na literatura portuguesa a partir da segunda metade do século XIX.

A parte disso, neste período ainda "muitos outros escritos, entre o ficcional e o cronístico, são publicados [...] frequentemente da autoria de oficiais, de diplomatas, de funcionários de administração, que vão dando conta das suas impressões de viagem, do exotismo da paisagem ou dos costumes, da história política e social locais" (LIMA, 1999, p. 149). Deste modo, a literatura de viagem se torna um gênero muito popular da segunda metade do século XIX até as primeiras décadas do século XX.

Tratando rapidamente de Antero de Quental, que nunca viajou ao Oriente, os críticos enxergam o Oriente expresso pelo autor das Odes Modernas como uma "pátria subjetiva" (LIMA, 1999, p. 149), em que "ora rescende a um certo parnasianismo fascinado pelos esplendores balsâmicos do Oriente, ora é já da ordem da experiência mística e metafísica" (LIMA, 1999, p. 150). Variando entre um "orientalismo um tanto decorativo" (MACHADO, 1983, p. 77) e uma "visão parcial do Oriente em que o misticismo cristão assimila o misticismo oriental" (MACHADO, 1983, p. 74), o Oriente em Antero aparece, sobretudo, nas suas ideias acerca da crença budista. Álvaro Manuel Machado enxerga o budismo anteriano como paradoxal (MACHADO, 1983, p. 77), sendo, num primeiro momento, uma interpretação "um tanto nebulosa, assimilando-o então ao cristianismo, considerado por Antero religião superior" (MACHADO, 1983, p. 75), e, num momento posterior, como uma "interpretação [...] agora diferente, mais profunda e, digamos, “isenta”' (MACHADO, 1983, p. 75). Isabel Pires de Lima também vê o Oriente anteriano como indistinto, composto por estudos, às vezes mal interpretados, sobre fés orientais e sua educação de caráter cristã:

o conceito de "misticismo activo" sobre o qual Antero laborou confusamente, entrecruzando o pessimismo aprendido na filosofia 
alemã e uma concepção difusa de Nirvana ora de origem budista [...], ora de origem hinduísta [...]; tudo isso envolvido numa roupagem talhada na sua educação cristã. A visita obsessiva da morte a que a obra de Antero procede é em boa parte bebida da leitura nem sempre lúcidas do budismo e do hinduísmo bastante divulgados, à época, nos meios orientalistas franceses e alemães (LIMA, 1999, p. 150).

Paulo Feitais, ao estudar o budismo anteriano, procura aprofundar a reflexão

sobre a relação entre o poeta e a crença oriental. Ele a resume da seguinte forma:

A relação de Antero com o Budismo não é linear, nem se trata de uma adesão acrítica a um sistema de pensamento atractivo pelo seu exotismo: há ao longo dos anos uma reflexão constante em torno do misticismo Ocidental e Oriental que não resulta de uma mera curiosidade intelectual, antes está profundamente enraizada na especulação anteriana, acompanhando as suas vicissitudes e perplexidades. Antero, desde muito cedo que se sente atraído pela dimensão moral do Budismo, encarado como disciplina de vida assente na prática da virtude. Nas fases precoces da articulação do pensamento anteriano, há uma atração pelo estoicismo, que é renovada e intensificada na fase aguda da doença, mas esse fascínio pela moral estoica irá diluir-se progressivamente na reflexão em torno do Budismo. [...] A última fase do pensamento anteriano assentará numa concepção metafísica do universo configurada de acordo com as coordenadas de uma monadologia que assume a liberdade, não apenas a partir da dimensão prática da razão, mas encarada como a verdade última de todos os seres. Será, então, o leibnizianismo que servirá de plataforma de ancoragem da reflexão de Antero em torno do Budismo. (FEITAIS, 2007, p. 118-119, grifo do autor).

A partir dessa ponderação, pode-se notar que a partir da geração de 70 o Oriente começa a ganhar reflexões mais profundas na intelectualidade portuguesa. Eça de Queirós contribuirá para o aprofundamento desse pensamento, porém de maneira diversa de Antero, como veremos.

No final do século XIX e no começo do XX, com as gerações simbolista, decadentista e modernista, o Oriente continuará a ser tema recorrente na poesia portuguesa. Diversos nomes como Camilo Pessanha (1867-1926), António Feijó (18591917), Fernando Pessoa (1888-1935), Mário de Sá-Carneiro (1890-1916), Eugênio de Castro (1869-1944), Almada Negreiros (1893-1970), António Patrício (1878-1930), Júlio Brandão (1869-1947), Fernando Leal (1846-1910), entre outros representam de alguma forma o Oriente em seus versos. Devido a grande quantidade de nomes que 
nessa época trabalham com o Oriente, nos é inviável visitar, mesmo que rapidamente, a poética de cada um. Destacamos aqui apenas três poetas que tiveram uma relação fortemente marcada em sua poesia com o Oriente, mais especificamente a China. O primeiro foi Camilo Pessanha, autor de Clepsidra (1920) que partiu para Macau pouco depois de formado em Coimbra, em 1894, e por lá ficou durante toda sua vida, à exceção de dois intervalos pouco demorados em que esteve em Portugal (MACHADO, 1996, p. 375). Além de seus poemas, Pessanha também traduziu poemas chineses para a língua portuguesa - publicados em Elegias chinesas (1914) - e deixou alguns textos ensaísticos em prosa, publicados postumamente como China (1944), "nos quais o poeta insurge contra a banal exploração do exotismo oriental" (MACHADO, 1983, p. 94). Manuela Ramos lê Camilo Pessanha como "o representante mais completo do orientalismo português" (RAMOS, 2001, p. 178). Mas, pondera:

[Camilo Pessanha] produziu textos de cariz orientalista, na acepção saidiana do termo, em que veiculou uma imagem extremamente generalizada, redutora e negativa do 'caráter' chinês, da civilização chinesa, com uma reduzidíssima capacidade de análise do papel ocidental nesse "vasto podredoiro". Por outro lado, a sua reflexão aprofundada sobre a peculiaridade da poesia e da escrita chinesas fazem dele um dos mais interessantes intérpretes do orientalismo na sua faceta positiva, ou seja, como veículo de uma viagem transformadora ao estranho e não familiar. Tal como a sua excelência de poeta, e a sua utilização de processos poéticos afins aos da escrita poética chinesa, na esteira dos seus pares europeus. (RAMOS, 2001, p. 178).

António Feijó nunca foi à China, mas, assim como Pessanha, traduziu poemas chineses, via versões francesas, publicados em Cancioneiro Chinês (1890). Diz Álvaro Manuel Machado que é a partir dessa publicação "que o elemento orientalista se torna determinante" (MACHADO, 1983, p. 86) em sua poesia. "Há aí uma obsessiva idealização do Oriente, um Oriente, aliás, mais pitoresco do que realmente mítico, embora um pitoresco que tende para a cristalização simbolista" (MACHADO, 1983, p. 86-87). Isabel Pires de Lima ratifica Machado, ao afirmar: 


\begin{abstract}
António Feijó, se já em À Janela do Ocidente manifesta a incomodidade da sua condição de poeta ocidental, é sobretudo em Cancioneiro Chinês - como o título sugere - e depois em Sol de Inverno, que o Oriente emerge idealizado e pitoresco por contraposição a um Ocidente decadente e falho de imaginação. António Feijó, de resto, está num ponto de confluência entre o parnasianismo, decadentismo e simbolismo, no que à questão orientalista, e não só, diz respeito, visto que o Oriente é fonte de preciosismo descritivo mas já próximo da cristalização simbolista e da experiência decadentista. (LIMA, 1999, p. 153)
\end{abstract}

Fernanda Romano, ao estudar as traduções feitas em Cancioneiro Chinês, concorda em parte com os estudiosos aqui citados ao destacar que, apesar de ser um poeta associado à escola parnasiana, António Feijó “excedeu os limites dessa escola literária" (ROMANO, 2013, p. 42). Também relativiza o fato das traduções deste livro se darem via traduções francesas: "É possível perceber que [...], apesar de o Cancioneiro Chinês configurar-se como o resultado de uma tradução em segunda via, o universo cultural chinês parece manter-se, também, como referência para o nosso poeta" (ROMANO, 2013, p 49).

Manuela Ramos, que também estudou o Cancioneiro Chinês, conclui suas reflexões sobre este autor afirmando que na poesia de Feijó

não se encontra nenhum tipo de orientalismo negativo de tipo saidiano. O seu Cancioneiro Chinês, de modo tão profissionalmente poético, é o exemplo português mais completo do que MacKenzie apelida de progressão orientalista: influência positiva e libertadora em algumas obras dos artistas ocidentais, dos motivos, temas e imagens da arte oriental. (RAMOS, 2001, p. 178).

De acordo com Isabel Pires de Lima, ainda vemos que Feijó produziu outras obras de caráter orientalista como À Janela do Ocidente $(1885)^{18}$ e Sol de Inverno (1922).

Já António Patrício, diplomata e poeta, teve seu primeiro posto consular em Cantão e, após percorrer diversas partes do mundo como representante oficial português, foi em Macau, a caminho de Pequim, também a trabalho, que veio a falecer. O Oriente,

\footnotetext{
${ }^{18}$ Gomes Leal, em Claridades do Sul (1875) possui um poema com este mesmo título.
} 
em sua poesia é normalmente lido ora "uma espécie de cenário onde se projectam os seus temas obsessivos da estesia da morte, da busca absoluta do amor, do sentimento português da saudade [...], ora um espaço mítico e nostálgico, o Oriente perdido das navegações, que só a memória-saudade pode recuperar" (LIMA, 1999, p. 157) ${ }^{19}$.

No entanto, neste período entre séculos, já fora do campo da poesia, quem mais se destaca é a figura de Wenceslau de Moraes (1854-1929). Inicialmente membro da marinha portuguesa, cedo parte para o Oriente onde se estabelece, primeiramente em Macau, onde vive de 1891 a 1899, mudando-se para o Japão onde exerce a função de cônsul português nas cidades de Kobe e Osaka, até pedir exoneração em 1913 e se mudar para Tokushima, onde fica até sua morte. Em quase quarenta anos instalado no Oriente, sendo trinta no Japão, Wenceslau produziu inúmeros textos, em sua maioria ensaios ou crônicas, em que descreve a vida, os costumes e as culturas chinesa e, principalmente, japonesa. Destacamos as obras Dai Nippon (1897), Paisagens da China e do Japão (1906), O-Yoné e Ko-Haru (1923), Relance da História do Japão (1924) e Relance da Alma Japonesa (1926). A crítica costuma ler a obra de Wenceslau como uma "mera preocupação cultural enciclopédica" (MACHADO, 1983, p. 85) ou como crônica "impressionista do exotismo oriental” (LIMA, 1999, p. 155), e considera que em suas “obras finais, mais acentuadamente saudosistas, o Japão revela-se $O$ Jardim do Encanto Perdido, para parafrasear o título de um dos estudos que Armando Martins Janeira lhe dedicou em 1955" (LIMA, 1999, p. 156). A assimilação da cultura japonesa por Wenceslau foi singular, a ponto de ser lido por parte da crítica portuguesa como alguém que morreu japonizado (LIMA, 1999, p. 156) ou como um homem que "trocou sua alma", conforme aponta Machado (1983, p. 83), parafraseando uma leitura de Fidelino de Figueiredo de 1929. O recente estudo de Érika Horigoshi (2012) sugere um

\footnotetext{
${ }^{19}$ Leitura idêntica é feita por Álvaro Manuel Machado (1983, p. 98-103).
} 
novo pensamento acerca de algumas leituras já cristalizadas acerca da obra de Moraes, propondo uma reflexão mais profunda da questão entre Oriente e Ocidente nos textos do autor de Dai Nippon.

Este panorama, que se inicia no século XVI se estendendo até a primeira metade do século XX, montado a partir de outros painéis feitos por estudiosos portugueses, apresenta, no entanto, suas limitações. Afinal, se se podem excluir desse panorama, por exemplo, as produções de conhecimentos sobre o Oriente a partir das missões religiosas com o óbvio argumento que esses textos não possuem uma intenção literária definida, sendo, como dissemos, mais antropológicos que literários, o mesmo não se pode dizer de muitos textos produzidos a partir das colônias portuguesas, principalmente Goa e Macau. Nessas colônias, durante os séculos XVI, XVII e XVIII a imprensa esteve presente por conta dos jesuítas (GARMES, 2003, p. 65), sendo restabelecida em 1821 em Goa (GARMES, 2004, p. 23) e em 1822 em Macau (GARMES, 2003, p. 65). Com o ressurgimento da imprensa nas colônias orientais portuguesas, periódicos como o $\mathrm{Ta}$ ssi-yang-kuo - Semanario macaense d'interesses públicos locaes, litterario e noticioso (1863-1866, posteriormente retomado de 1889-1904, com o mesmo título, mas com outro subtítulo $^{20}$ ) em Macau e o O Ultramar (1859-1941) ${ }^{21}$ em Goa, entre outros, ganharam vida, publicando em suas páginas produções literárias em língua portuguesa de portugueses e seus descendentes - muitas vezes excluídas do cânone da literatura lusa. Estudos recentes como os de Hélder Garmes ${ }^{22}$, Mônica Simas ${ }^{23}$ e Damares Barbosa Correia ${ }^{24}$, no Brasil; e, em Portugal, Joana Passos ${ }^{25}$, Everton Machado ${ }^{26}$ ou

\footnotetext{
${ }^{20}$ Cf. GARMES, 2003, p. 76

${ }^{21}$ Cf. GARMES, 2004.

${ }^{22}$ GARMES, Hélder. (org.) Oriente, Engenho e Arte. - Imprensa e literatura de língua portuguesa em Goa, Macau e Timor Leste. São Paulo: Alameda Casa Editorial, 2004.

${ }^{23}$ SIMAS, Mônica. Margens do Destino: Macau e a literatura em língua portuguesa. São Caetano do Sul: Yendis, 2007.

${ }^{24}$ CORREIA, Damares Barbosa. Roteiro da Literatura de Timor-Leste em língua portuguesa. Tese (Doutorado em Letras) Faculdade de Filosofia Letras e Ciências Humanas, Universidade de São Paulo, São Paulo, 2013.
} 
João C. Reis ${ }^{27}$, entre outros, têm tentado levar ao público essa literatura produzida nas colônias orientais de Portugal.

Como se pode depreender, este orientalismo literário português intersecular, que compreende da segunda metade do século XIX à primeira metade do século XX, é abundante e complexo. São inúmeras obras publicadas num período de aproximadamente um século. A crítica de um modo geral tende a interpretar o Oriente na literatura portuguesa dentro de algumas tendências de leitura, a maioria já destacadas. Um orientalismo de caráter nacionalista ou heroico; um orientalismo pautado pelo exotismo; um orientalismo expresso na busca de um exílio ou de um paraíso subjetivo; um orientalismo saudosista, às vezes saudade dos tempos gloriosos da nação portuguesa, às vezes saudade de um Oriente "puro" que se perdeu diante da modernização; e um orientalismo livresco estão entre as principais formas de interpretação, embora não se limitem apenas a essas. Acreditamos que se deve tomar cuidado com uma associação rápida dessas tendências interpretativas às obras de alguns autores, pois se possivelmente há escritores cujas obras se limitam a corroborar estas imagens depreendidas, há também outros cujos textos, numa leitura mais detalhada, revela-nos uma visão mais elaborada do Oriente, como recentes estudos, alguns apontados por nós anteriormente, têm tentado demonstrar. Deste modo, cremos que, se relidas algumas obras de "autores-chave" dessa época tão importante na formação do pensamento português contemporâneo, poder-se-ão encontrar, nas entrelinhas de seus textos, diálogos mais complexos com este Oriente representado.

Ao nos defrontarmos com este desafio de analisar textos que possuem representações ou características orientalistas, devemos levar em consideração alguns

\footnotetext{
${ }^{25}$ PASSOS, Joana. A Literatura Goesa em Português nos Século XIX e XX: Perspectivas pós-coloniais e revisão crítica. Ribeirão: Húmus, 2012.

${ }^{26}$ Organizador da edição crítica do romance Os Brahamanes (1866) de Francisco Luís Gomes, publicado em 2012, na França, através da Éditions Classique Garnier.

${ }^{27}$ REIS, João C. Trovas Macaenses. Macau: Mar-Oceano editora, 1992.
} 
aspectos, como quem, quando, onde, de onde e, principalmente, qual a relação do autor com o local ali representando no texto - aspectos elementares de qualquer análise literária. Deste modo, ao trabalharmos com o orientalismo literário português, poderíamos dividir as obras em quatro grandes grupos, tomando por referência o lugar de enunciação do escritor: o primeiro seria composto por autores que retratam o Oriente, seja ele o Próximo ou o Extremo, em seus textos sem de fato ter a experiência in loco; o segundo seria de obras de autores que tiveram contato direto com o Oriente em uma breve passagem, em sua maioria como turistas; o terceiro seria representado por autores portugueses que tiveram um contato longo com terras orientais, coloniais portuguesas ou não, e transmitiram tal experiência em seus escritos; e o quarto seria composto por autores radicados ou nativos de colônias portuguesas na Ásia. Embora a classificação que aqui propomos seja uma classificação básica e globalizante, e possa não contemplar possíveis peculiaridades de alguma obra ou de algum autor, acreditamos ser um possível ponto de partida para uma análise mais específica da produção orientalista de cada autor, minimizando, assim, que comparações entre autores com experiências muito diversas com o Oriente sejam analisadas de uma mesma maneira. Ou que, caso tais análises sejam feitas, sejam destacadas essas características que relativizam a comparação.

Centremos nossas atenções, a partir de agora, em Eça de Queirós. No próximo item, procuraremos apresentar, através de sua biografia, os pontos de contato entre o Oriente e o escritor, e também um levantamento dos textos em que o Oriente é referido.

\subsection{OS ORIENTES DE EÇA DE QUEIRÓS}

Como referido no item anterior, Eça de Queirós foi um dos principais nomes da literatura portuguesa a "redescobrir", na segunda metade do século XIX, o Oriente. O 
contato direto de Eça com o Oriente foi rápido, porém fundamental para sua produção artística. O autor de Os Maias em 23 de outubro de 1869, então bacharel recém-formado em Coimbra com 23 anos, embarcou acompanhado de seu amigo e futuro cunhado Conde de $\operatorname{Resende}^{28}$ em uma viagem ao Egito com o propósito de assistir a inauguração do Canal de Suez. Esta viagem durou aproximadamente três meses, com Eça e Conde de Resende aportando em Lisboa novamente em 3 de janeiro de 1870. Nesta viagem cujo trajeto permitiu Eça conhecer outras localidades como Cádiz e Gibraltar na Espanha e Malta - o jovem bacharel e seu futuro cunhado não se limitaram a conhecer apenas as terras egípcias. Percorreram também a Terra Santa, visitando a Palestina e a Alta Síria. Jaime Batalha Reis, na introdução às Prosas Bárbaras (1903) resume a importância dessa viagem. Ao relembrar a tarde em que Eça retornara de sua viagem pelo Oriente Próximo diz: "Ouvimo-lo toda aquela tarde, fomos jantar com ele - não o podíamos largar. As ideias estéticas de Eça de Queirós haviam-se, a esse tempo, profundamente modificado" (REIS, 1958, p. 568). Parece-nos fato o afirmado por Jaime Batalha Reis, pois tal viagem fez com que Eça mergulhasse em leituras - antes e depois da excursão - acerca da Terra Santa, a religião cristã e suas principais figuras. Jaime Batalha Reis (1958, p. 568) cita Vida de Jesus (1863) e São Paulo (1869) de Ernest Renan, Memórias de Judas (1867) de Ferdinando Petruccelli della Gattina (1815-1890) e Salambô (1862) e a Tentação de Santo Antão (1874) de Gustave Flaubert (1821-1880). Pouco após seu retorno, e já próximo às Conferências do Casino Lisbonense - seu período mais combativo - Eça escreve um conto, aparentemente inacabado (BUENO, 2007, p. 307) intitulado “A Morte de Jesus”, publicado no periódico Revolução de Setembro entre abril e julho de 1870, hoje parte das Prosas Bárbaras. Seja através da experiência direta, seja pela literatura que Eça consumiu a partir da possibilidade de

\footnotetext{
${ }^{28}$ Seu nome era D. Luís de Castro Pamplona, de acordo com A. Campos Matos (1988, p. 220).
} 
conhecimento de terras orientais, a viagem de Eça foi fundamental para o desenvolvimento de dois tópicos importantes de sua literatura: as figuras bíblicas e a igreja católica $^{29}$. Tais temas permearão a imaginação de Eça durante toda sua carreira literária, desde os primeiros romances, como O Crime do Padre Amaro, cuja primeira versão data de 1875 mas com sua versão definitiva e bastante alterada em 1880, até as inacabadas Lendas dos Santos (1912), isso passando por romances como A Relíquia (1887), e contos de diversas épocas como "Senhor Diabo" (1867), "O Suave Milagre" (1898, a última versão), entre outros.

No entanto, a viagem ao Egito, Palestina e Alta Síria não renderá frutos apenas na ficção queirosiana. Talvez influenciado por Flaubert ${ }^{30}$ que também viajara ao Egito e a Jerusalém e deixara escritas suas impressões, talvez na intenção de exercitar seu estilo, Eça redige inúmeras notas de viagem. Embora tivesse a intenção publicá-las (CAMPOS MATOS, 1988, p. 219), Eça nunca levou a público suas anotações. Partes destas foram reunidas e adaptadas sob responsabilidade dos filhos de Eça, José Maria e Alberto (CAMPOS MATOS, 1988, p. 221) e publicadas em 1926 sob o título de O Egito. As anotações que correspondem às impressões da Palestina e da Alta Síria ainda levaram mais 40 anos para serem reveladas, cabendo a filha de Eça, Maria, a versão de 1966 publicada em Folhas Soltas. Apesar de nunca ter revisado e publicado suas notas de viagem, estas foram úteis a Eça para compor algumas cenas de sua ficção. Campos Matos diz que "do material [...] sairia depois A Relíquia, um capítulo da Correspondência de Fradique Mendes, as recordações de Malta utilizada n'O Mistério da Estrada de Sintra e a visão do deserto do conto Santo Onofre" (CAMPOS MATOS,

\footnotetext{
${ }^{29}$ Aparecida de Fátima Bueno (2007, p. 314) ainda destaca que "nem os escritores contemporâneos de Eça, nem os que vieram depois, foram tão fundo na revisão crítica que fizeram da imagem de Cristo e do papel da Igreja na sociedade portuguesa de então".

${ }^{30}$ Beatriz Berrini (2000, vol. 3, p. 1821) destaca além de Flaubert, Chateubriand, Nerval e Lamartine como leituras do "'afrancesado' jovem José Maria da época”, como possíveis fontes de inspiração. Isabel Pires de Lima (1997, p. 84) também aponta os mesmos autores como referências do jovem Eça. Campos Matos (1988, p. 222) ainda lembra de outros autores como Maxime du Camp (1822-1894), Edmont About (1828-1885) e Théophile Gautier (1811-1872).
} 
1988, p.219-220). De textos não ficcionais, ainda temos a crônica “De Port-Said a Suez" (1870), publicada em quatro folhetins no Diário de Notícias pouco após seu retorno da viagem. Apesar de não possuir direta relação com a viagem de Eça, o Oriente Próximo ainda aparecerá em outros textos queirosianos não ficcionais como "Os Ingleses no Egito" (1882); as Cartas de Londres (1877), composta por quinze crônicas escritas a partir de Newcastle nas quais, em sua maioria, é tratado de um conflito bélico entre Rússia e Turquia; e uma reflexão da mulher muçulmana no Almanaque das Senhoras (1871). Esta última referência, quem nos lembra é Maria Lúcia Wiltshire Oliveira (2001, p. 241).

O texto de $O$ Egito já foi algumas vezes analisado e é tido como um dos principais textos para se compreender o Oriente em Eça de Queirós. Maria Lúcia Wiltshire de Oliveira diz que neste texto:

Desprovido tanto da máscara europeia a endossar o modelo desenvolvimentista de progresso, quanto da máscara portuguesa a fazer o elogio da vida aldeã trasmontana, Eça é arrebatado pela singularidade de uma cultura - o Islão exótico e pitoresco do presente e o Egito da Antiguidade - relegando ao segundo plano a inauguração de Suez, obra-símbolo da intervenção civilizatória do Ocidente sobre o Oriente. (OLIVEIRA, M., 2001, p. 245)

Adiante, afirma que "em $O$ Egito, o olhar do ocidental sobre o Oriente está no entrelugar da dicção romântica, de cunho fantasista, e da visão realista, de cunho pretensamente científico" (OLIVEIRA, M., 2001, p. 246), ressaltando que Eça “é capaz de ver o Oriente - em vias de se tornar protetorado britânico - de um ponto de vista menos intervencionista. $\mathrm{Na}$ direção oposta aos interesses eurocêntricos, ele vai apoiar os nacionalistas no conflito anglo-egípcio do final do século do progresso" (OLIVEIRA, M., 2001, p. 249). É desta forma, então, que a estudiosa conclui que "o livro de Eça efetivamente engrossa a massa de discursos sobre o Oriente e 'contribui' para a construção de um saber sobre a terra dos faraós no século XIX” (OLIVEIRA, M., 2001, p. 250). 
Isabel Pires de Lima também lê $O$ Egito de Eça dentro do "orientalismo canônico" (1997, p. 88), que oscila entre o mítico e o real $(1997, \text { p. } 95)^{31}$. No entanto, ressalta que apesar de o Oriente "ter um ar de deja-vu e entedia-o quando a realidade já não corresponde ao mito" (LIMA, 1999, p. 151), “quase sempre deixa-se fascinar pelo Egito real, antigo ou contemporâneo" (LIMA, 1999, p. 151). A estudiosa lembra das influências de Taine nos desenhos feitos por Eça do Egito contemporâneo, concluindo que "Eça revela-se um espírito original no vasto campo do orientalismo oitocentista" (LIMA, 1999, p. 151). Em outro texto, a pesquisadora ainda coteja as anotações de viagem de Eça com as de Flaubert, destacando que, em muitos momentos, "O Oriente se confunde [...] com pansexualismo ${ }^{32 "}$ (LIMA, 1991, p. 26, tradução nossa) para o autor francês, enquanto "Eça de Queirós é mais sensível ao Egito contemporâneo ${ }^{33 "}$ (LIMA, 1991, p. 27, tradução nossa).

Carlos Reis, na introdução à edição comercial de $O$ Mandarim, faz uma leitura próxima a de Isabel Pires de Lima. Ao contextualizar o Oriente na bibliografia queirosiana, o estudioso diz:

De onde vem a Eça este (aparentemente inesperado interesse pela China? Que episódios o anunciam e o que se lhe segue? [...] a sedução pelo exotismo que em Eça emerge, quando visita o Egito e a Palestina, levando consigo a memória de viajantes ilustres, de Chateaubriand a Flaubert, passando por Nerval, Lamartine, Renan e outros mais. Acrescente-se, entretanto, que já então o jovem Eça não reduzia o seu trajeto a essa sedução exótica: a Palestina e sobretudo o Egito são observados também em função de um olhar atento às incidências sociais e a condicionamentos climáticos que se deixam perceber a lição do Taine viajante. (REIS, 2003, p. 13)

Deste modo, de uma maneira geral, $O$ Egito de Eça normalmente é lido como uma contribuição queirosiana a uma produção orientalista europeia, assim como

\footnotetext{
${ }^{31}$ Monica Simas procura relativizar parte dessa leitura de Isabel Pires de Lima ao afirmar que "em suas anotações sobre o Egito, são descritas particularidades que não correspondem a essa tradição, como as referências ao conluio entre os chefes locais e o poder ocidental" (SIMAS, 2007, p. 93).

32 "l'Orient se confond [...] avec pan-sexualisme" (no original).

33 "Eça de Queirós est encore plus sensible à l'Egypte contemporaine" (no original).
} 
também serve como fonte de inspiração, imaginação e reflexão para o escritor, além de ser um produtivo exercício de olhar ao "Outro".

Retornado de sua viagem ao Oriente, Eça se tornou diplomata português em 1872, função que exerceu até o fim de sua vida em quatro localidades: Havana, nas Antilhas Espanholas (1872-1874); Newcastle (1874-1879) e Bristol (1879-1888), na Inglaterra e Paris, na França (1888-1900). Em Havana, aconteceu seu segundo contato com Oriente. Na ilha cubana, o autor de $O$ Primo Basílio se deparou com um grande número de emigrantes chineses trabalhando em situação equivalente a de escravidão. Ou seja, Eça presenciou "a situação deplorável em que se encontravam em Cuba chineses provindos de Macau que vinham trabalhar nas fazendas de empresários espanhóis" (MAGALHÃES, 2000, p. 13-14) e advogou em nome desses emigrantes por melhores condições. A situação dos trabalhadores asiáticos era responsabilidade da autoridade portuguesa na ilha devido às saídas se darem a partir do porto de Macau, então território lusitano. “[...] De acordo com o regulamento de emigração daquela possessão, [os chineses] eram beneficiados da proteção consular portuguesa" (MAGALHÃES, 2000, p. 13), mesmo que suas origens fossem outras regiões da China. Sobre a relação de Eça com os trabalhadores chineses, chamados de coolies $^{34}$, diz Eusébio Leal Spengler:

Nos seus períodos de trabalho intenso, [Eça] assiste a um novo drama: a importação de chineses coolies [...] matizando a realidade do país com a sua cultura e domínio das técnicas agrícolas. Essa questão interessa-o particularmente e [...] seus protestos quotidianos e a coragem do seu comportamento em favor dos oprimidos e explorados leva-o a advogar pela extinção do infame comércio. (SPENGLER, 2000, p. 25).

Ainda a esse respeito, Monica Figueiredo destaca que "O espírito socialista gerado pelas leituras de Proudhon não permitirá que Eça feche os olhos à situação

\footnotetext{
${ }^{34}$ Para maiores detalhes sobre a relação do tráfico dos coolies e a economia portuguesa/macaense da época, cf. SERRÃO, José Vicente, 1998, p.749-751.
} 
ultrajante a que estavam submetidos os coolies" (FIGUEIREDO, 2005, 112). Assim, a atuação de Eça em prol dos chineses ${ }^{35}$ representa mais um contato com o Oriente, neste caso, o Extremo Oriente, lugar em que o escritor português nunca esteve in loco.

Apesar deste último fato, o Extremo Oriente está mais presente em sua bibliografia do que se julga em uma leitura superficial. Da experiência direta com os chineses, surgiu o relatório consular redigido por Eça em 1874, pouco antes de embarcar a Newcastle, que só veio a público em 1979 sob o título de A Emigração como Força Civilizadora. Na sua ficção, destaca-se a novela $O$ Mandarim (1880), com parte de seu enredo se passando na China. Ainda, encontramos referências ao Extremo Oriente em O Mistério da Estrada de Sintra (1870), A Correspondência de Fradique Mendes (1900), além “da franca utilização de elementos culturais chineses, presentes no pano de fundo de muitas de suas descrições ficcionais" (FIGUEIREDO, 2005, 113), entre as quais podemos destacar $O$ Crime do Padre Amaro e A Cidade e as Serras (1900). No plano dos textos de imprensa, destacam-se artigos escritos ao longo de toda sua carreira jornalística. Nos textos que posteriormente vieram a ser publicados como Prosas Bárbaras existem referências ao poeta chinês Li Tai-Pé36 (701-762); em As Farpas (1871-1872) encontramos dois textos que tratam das colônias portuguesas no Oriente; em Cartas da Inglaterra (1877), a sexta carta trata da fome na Índia; no texto "Notas do Mês" de fevereiro de 1890 publicado no volume 2, número 2 da Revista de Portugal há referências à China; em textos publicados no jornal carioca Gazeta de Notícias encontramos diversos artigos, dentre os quais sobressaem o primeiro texto escrito para o periódico carioca, intitulado apenas "Cartas de Paris e Londres", datada

\footnotetext{
${ }^{35}$ Em carta de 28 de novembro de 1878 a Ramalho Ortigão, Eça diz sobre suas intervenções a favor dos chineses: "eu na Havana era apenas pago pelos chins, pelos serviços que lhes fazia: pagavam-me bem, honra seja [feita] aos chins, e deram-me uma bengala de castão de ouro! É verdade que eu pelo menos por alguns anos futuros garanti-lhes mais pão e menos chicote" (QUEIRÓS, 2000a, vol. 4, p. 133).

${ }^{36}$ Esta é a grafia adotada por Eça. Outras grafias possíveis são Li Bai, Li Bo, Li Po, Li Pai, ou Li Tai-Po, entre outros. Este poeta é um dos mais importantes da dinastia Tang (618-907).
} 
de seis de junho de 1880, “A França e o Sião” (1893), “Chineses e Japoneses” (1894), “A Propósito da Doutrina Monroe e do Nativismo" (1896), “Ainda as Festas Russas Os Jornais" (1896), e “As Catástrofes ou as Leis da Emoção" (1897); ainda há um artigo intitulado "França e Sião" (1897) que foi publicado na Revista Moderna de Paris.

A partir desse panorama traçado da bibliografia de Eça acerca do Oriente, podemos ver que o autor de $O$ Mandarim se encaixaria no segundo grupo da divisão do orientalismo literário português que apresentamos anteriormente, pois, apesar de seu contato direto com o Oriente ter se restringido a sua viagem de três meses e o período que trabalhou em contato com a colônia de imigrantes chineses de Havana ${ }^{37}$, esta experiência influenciou diretamente sua produção ficcional e jornalística. Ainda, outra importante fonte de informação de Eça a respeito dessa região do mundo são os livros.

A obra de Eça de Queirós, como outros textos orientalistas portugueses, normalmente é encaixada dentro de algumas das "chaves de leitura" que destacamos no item anterior. Deste modo, não é raro nos depararmos com leituras em que o Oriente em Eça de Queirós seja uma reprodução de um "imaginário exótico e caricatural” ou um "orientalismo de moda fin de siècle importado das artes francesas". Deve-se ressaltar que, no caso de Eça de Queirós, outra interpretação faz-se presente na crítica: a leitura de um Eça de Queirós crítico do imperialismo europeu, sendo a postura do escritor aproximada da teoria orientalista de Said, conforme pode-se começar a perceber através das leituras aqui citadas do texto $O$ Egito. Entretanto, durante nossas leituras chamounos a atenção o posicionamento das obras de Eça dentro dessas tendências interpretativas, pois nos pareceu haver algo além da reprodução de uma moda epocal ou da crítica às estratégias políticas de seu continente, embora reconheçamos que este fato

\footnotetext{
${ }^{37}$ Embora tenha ficado oficialmente pouco mais de um ano (do final de 1872 a meados de 1874) em Havana, devido, principalmente, a problemas de adaptação ao clima local, Eça teria trabalhado por apenas meses (de janeiro a maio de 1873, de novembro de 1873 a primavera de 1874) em solo cubano, conforme nos informa Magalhães (2000, p. 14-16).
} 
por si só é suficiente para destacar o autor de $O$ Mandarim dentro de um panorama orientalista europeu. Portanto, a possível existência deste "algo a mais" no orientalismo queirosiano foi um dos principais fatores motivadores para o desenvolvimento deste estudo.

Em nosso trabalho, nos limitaremos a estudar as obra de Eça acerca do Extremo Oriente. Tal fato se justifica por dois aspectos: 1) estudar as obras que abranjam tanto o Oriente Próximo quanto o Extremo Oriente seria um trabalho complexo e demasiadamente longo para uma dissertação de mestrado; 2) embora estudar o Oriente em Eça não seja absolutamente inédito, notamos que os trabalhos que se debruçam sobre o tema, normalmente privilegiam o Oriente Próximo. Deve-se ressaltar que exceção é feita ao estudo da China em $O$ Mandarim. São abundantes os estudos que refletem sobre o Oriente nessa obra $^{38}$. Ainda, muitos estudos costumam se deter em análises isoladas, contemplando apenas uma das obras. Poucos são os textos que examinam comparativamente essa região do globo nas obras queirosianas. Deste modo, nota-se nos estudos de um orientalismo queirosiano duas lacunas: estudos mais globalizantes, que tentem estabelecer uma visão geral de um Oriente eciano baseado em diversas obras em detrimento de textos isolados; e um estudo mais profundo sobre o Extremo Oriente em Eça, região nunca visitada pelo autor. Assim, partindo de um selecionado de textos de diversos gêneros e de diferentes períodos literários do autor, intencionamos dar nossa contribuição para supressão desses espaços presentes na crítica queirosiana. Para tanto, vamos dividir nossa análise em dois grupos de textos: obras não-ficcionais, em que trabalharemos com A Emigração como Força Civilizadora; os textos "A Marinha e as Colônias" (1871) e "A Pitoresca História da Revolta da Índia" (1871) - publicados em As Farpas -, “A França e o Sião”, “Chineses e Japoneses”, “A

\footnotetext{
${ }^{38}$ Algumas análises sobre a China de $O$ Mandarim serão destacadas no capítulo 3 deste trabalho.
} 
Propósito da Doutrina Monroe e do Nativismo" - publicados na Gazeta de Notícias do Rio de Janeiro -, e "França e o Sião" da Revista Moderna de Paris; e obras ficcionais, em que serão analisados $O$ Mistério da Estrada de Sintra, $O$ Mandarim e A Correspondência de Fradique Mendes. No final do trabalho, tentaremos apontar semelhanças e diferenças depreendidas da análise dessas diversas obras para, enfim, podermos tentar entender como o Extremo Oriente se configura na obra queirosiana. 


\section{O EXTREMO-ORIENTE NAS OBRAS NÃO FICCIONAIS DE EÇA DE QUEIRÓS}

Principalmente conhecido por seus contos e romances, Eça de Queirós também possui uma vasta obra que vai além da criação ficcional. Desde seus tempos de jovem, o autor de Os Maias escreveu, muitas vezes sob pseudônimos, colaborações a jornais portugueses. Esta prática o acompanhará ao longo de toda a sua vida, e extrapolará as fronteiras de Portugal, já que Eça publicará textos em periódicos franceses e brasileiros.

Pensar nas obras não ficcionais de Eça de Queirós envolve um enorme grupo de textos, estilos e temas. Obviamente, pela dimensão deste trabalho, foi necessário fazer um recorte dentro deste grupo que envolve correspondências pessoais, correspondências profissionais, artigos escritos para periódicos, prefácios, entre outros textos. Para nosso objetivo, selecionamos, principalmente, textos de imprensa. O que nos leva a intitular o capítulo “O Extremo-Oriente nas Obras Não Ficcionais de Eça de Queirós” ao invés de “O Extremo Oriente nos Textos de Imprensa de Eça de Queirós" é a inclusão de um texto, parte dos documentos oficiais redigidos por Eça enquanto cônsul. Estamos falando de A Emigração como Força Civilizadora, escrito em 1874, mas somente coligido e publicado em 1979 por Raul Rego. Este texto nos é fundamental por tratar diretamente da relação entre Ocidente e Oriente em sua parte final, além de demonstrar o raciocínio de nosso autor nos primeiros anos consulares.

Os demais textos são parte da obra de Eça de Queirós enquanto jornalista. Como nosso objetivo é tentar identificar como o autor de $O$ Mandarim representa o Extremo Oriente ao longo de sua obra, selecionamos alguns textos de períodos distintos do autor. Observando a quantidade de textos que versam sobre este tema e a extensão deste trabalho, não nos é possível analisar todas as referências do Extremo Oriente nos textos não ficcionais de Eça. Assim, selecionamos o seguinte recorte: dois textos escritos em 
1871, inicialmente publicado em As Farpas, depois coligidos em Uma Campanha Alegre (1890-1891), nomeadamente os textos XVIII e XXXIV, também referidos pelos títulos de "A Marinha e as Colônias" e "História Pitoresca da Revolta da Índia"; três textos publicados na Gazeta de Notícias do Rio de Janeiro, sendo "A França e o Sião" (1893) parte integrante de Ecos de Paris (1905), e "Chineses e Japoneses" (1894) e "A Propósito da Doutrina Monroe e do Nativismo" (1896) parte de Cartas Familiares e Bilhetes de Paris (1907); e um texto publicado na Revista Moderna de Paris, postumamente inserido em Notas Contemporâneas (1909), intitulado "França e Sião" (1897). Vale destacar que procuraremos dialogar com outros textos queirosianos sempre que convier para a melhor compreensão de nosso estudo.

A fim de identificar o caminho percorrido pelas ideias do autor, optamos por analisar os textos de maneira cronológica. Exceção faremos a A Emigração como Força Civilizadora, que será analisada de antemão, uma vez que o gênero deste texto é distinto dos demais.

\subsection{O EXTREMO-ORIENTE EM A EMIGRAÇÃO COMO FORÇA CIVILIZADORA}

Entre os anos de 1873 e 1874, Eça de Queirós exerceu o cargo de cônsul português em Havana, onde teve que interceder por chineses que trabalhavam em um regime de escravidão em fazendas de proprietários espanhóis (BERRINI, 1993, p. 196). Como dissemos no primeiro capítulo deste trabalho, a situação dos trabalhadores chineses era responsabilidade da autoridade portuguesa devido às saídas se darem a partir do porto de Macau. Após o regresso de Eça a Lisboa, foi-lhe "solicitado um

relatório sobre a emigração que enviou no dia 9 de novembro" (MAGALHÃES, 2000, p. 16). Este documento foi publicado postumamente sob o título de A Emigração como 
Força Civilizadora. Dias após a entrega desse relatório o futuro autor de Os Maias foi transferido para Newcastle, Inglaterra, país onde trabalhou por mais quatorze anos (MAGALHÃES, 2000, p. 17-18), antes de se transferir para a França.

De acordo com o Dicionário de Eça de Queiroz (1988) organizado por A. Campos Matos, “o título foi extraído do último parágrafo" (p. 232), que diz:

Estudadas as feições da emigração livre, a história dos seus movimentos, as suas causas, as suas consequências econômicas, as suas relações com o Estado, e a possibilidade da sua organização universal, - discutida a emigração assalariada, nas suas correntes, e nos seus resultados sociais, - eu julgo terminado este trabalho, que é a afirmação, - e direi mesmo, - a apologia, da emigração como força civilizadora (QUEIRÓS, 2000a, vol. 3, p. 2084).

Este último parágrafo também nos é conveniente para compreender o conteúdo do texto. Como o próprio Eça nos expõe é um estudo "da emigração livre”, da "história dos seus movimentos" desde a antiguidade até sua contemporaneidade, refletindo sobre o fenômeno migratório de diversas nações europeias como Inglaterra e outras nações do Reino Unido, Espanha, Alemanha, França, Suíça, Itália, Portugal, entre outras; além de abordar também a emigração de nações asiáticas como a China.

Neste trabalho, vamos nos deter à parte VII do relatório, pois é o trecho em que o autor se dedica à emigração chinesa. Ao ler o texto, percebemos que Eça se baseou principalmente em sua experiência enquanto cônsul nas Antilhas Espanholas, mas não somente nesta. $\mathrm{O}$ conhecimento da situação da mão-de-obra chinesa em outras regiões do mundo como a Califórnia nos Estados Unidos e a Austrália, além de dados estatísticos foram de grande utilidade à análise feita por nosso autor.

Eça inicia sua argumentação acerca dos chineses fazendo uma breve introdução histórica. Analisa as situações das Antilhas Francesa, Inglesa e Espanhola que, sem escravos, precisavam encontrar uma maneira para suprir suas necessidades: "Naturalmente a primeira ideia das colônias [...] foi introduzir os negros africanos como trabalhadores livres, e transformar o antigo tráfico numa emigração legal” (QUEIRÓS, 
2000a, vol. 3, p. 2064). No entanto, "a prática trouxe grandes desilusões. Na Serra Leoa e na Bona Vista a população negra era formada pelos negros aprisionados por cruzeiros ingleses nos navios de tráfico". Ou seja, os africanos "viam [na emigração livre] a escravidão voluntária” (QUEIRÓS, 2000a, vol. 3, p. 2065). Situações semelhantes se repetiram nas colônias de outras nações europeias que viram na Ásia a fonte para a supressão de seus problemas. França e Inglaterra utilizaram mão-de-obra da Índia. Emigrantes indianos já trabalhavam, de acordo com os dados fornecidos por Eça, desde 1834 nas ilhas Maurícias. As Antilhas Espanholas optaram pelos chineses, que, segundo o autor português, representavam "a mais célebre e a mais discutida das emigrações asiáticas” (QUEIRÓS, 2000a, vol. 3, p. 2069).

Eça classifica seu texto como uma "mera curiosidade histórica" (QUEIRÓS, 2000a, vol. 3, p. 2069), uma vez que a emigração dos coolies (trabalhadores chineses) a Cuba já havia sido proibida em dezembro de $1873^{39}$ por Andrade Corvo (MAGALHÃES, 2000, p. 15), ministro dos Negócios Estrangeiros de Portugal, mesma autoridade que encomendou o relatório ${ }^{40}$. Eça, por sua vez, alerta que essa proibição, originada a partir da "reclamação contra o tráfico de cules por parte da Inglaterra e da França" (SIMAS, 2007, p. 95), tinha pouco de "filantropia e caridade" (QUEIRÓS, 2000a, vol. 3, p. 2069), e o que a movia era "incontestavelmente, uma excitação de interesse" (QUEIRÓS, 2000a, vol. 3, p. 2069), isto é, uma rivalidade colonial entre ingleses e franceses. Aqui já se começa a perceber a veia crítica do autor português que se desenvolverá nos anos seguintes - que consegue enxergar claramente os interesses políticos por trás das ações dos governos. O recém-chegado cônsul português

\footnotetext{
${ }^{39}$ José Vicente Serrão nos lembra que esta proibição aconteceu apenas no porto de Macau, continuando “a processar-se normalmente pelos outros portos..." (SERRÃO, José, 1998, p. 750).

${ }^{40}$ Monica Simas diz que esta "atividade, inicialmente considerada lícita pela administração portuguesa, precisou em breve ser regulamentada oficialmente e depois, através de várias leis, foi sendo coibida até a absoluta proibição em 1894." (SIMAS, 2007, p. 95). Assim, de acordo com esta autora, a proibição de 1873 seria uma das leis que serviu para "coibir" a ida dos coolies a Cuba, não sendo responsável pela extinção definitiva do tráfico.
} 
explica a situação, dando destaque à rixa entre a Inglaterra, França e Espanha. Em seguida, enumera os motivos que levaram à proibição: “Os vícios da emigração chinesa, tais como os apontava opinião hostil, eram dois: - o recrutamento na China e o transporte para a América. Eu acuso um terceiro, - o maior enquanto a mim: a situação dos coolies na ilha de Cuba" (QUEIRÓS, 2000a, vol. 3, p. 2070). Descreve o transporte dos chineses à ilha da América Central, dizendo-se impressionado com o asseio do navio. Diz que os trabalhadores chegavam à ilha "gordos, fortes, sãos, alegres, cheios de alimento" (QUEIRÓS, 2000a, vol. 3, p. 2073), mas que após o desembarque em solo cubano se iniciava a "verdadeira miséria dos coolies" (QUEIRÓS, 2000a, vol. 3, p. 2074).

O cônsul português em Havana defende o coolie livre, sem contrato de trabalho. Este diz: "uma experiência de 20 anos tem mostrado, que se há criatura trabalhadora, ocupada, produtiva, azafamada, é o coolie livre" (QUEIRÓS, 2000a, vol. 3, p. 2076). Continua por analisar a situação dos emigrantes asiáticos, mostrando seus problemas:

A situação dos coolies é hoje mais que nunca desgraçada. Os escravos estão na véspera da libertação; a emigração 'coolie' está proibida: - o elemento negro falta, - o elemento chino não pode ser renovado. Todas as necessidades de trabalho da Ilha têm de recair pesadamente sobre a colônia existente (QUEIRÓS, 2000a, vol. 3, p. 2078).

Por diversos trechos, destaca as qualidades dos trabalhadores asiáticos. Por exemplo, diz que "o coolie bem-tratado é dócil, submisso, familiariza-se com o navio" (QUEIRÓS, 2000a, p. 2074) ou também apresenta a "facilidade [dos chineses de] aclimatação, sobriedade e industriosidade para o trabalho" (QUEIRÓS, 2000a, vol. 3, p. 2070).

Nas últimas páginas de seu relatório, Eça conjectura uma emigração livre em Cuba e, assim inicia um balanço final da emigração chinesa. Cito o trecho:

Esta emigração livre poderia ter bom resultado em Cuba, mesmo atraída e solicitada? Não creio. O exemplo das relações entre a raça 
chinesa e a raça europeia, em concorrência de trabalho livre, na Austrália e na Califórnia, autorizam a crer, que a presença de uma população china livre nas colônias de raça latina terminaria deploravelmente (QUEIRÓS, 2000a, vol. 3, p. 2079).

Aqui, as considerações feitas em relação ao Império do Meio e seus habitantes contrastam com o apresentado até o momento. Conforme expomos nas citações, o colaborador de As Farpas traça uma contextualização da situação chinesa na colônia espanhola destacando os problemas enfrentados pelos orientais, como o contrato de trabalho, o recrutamento, as condições de vida na ilha, destaca a força e a habilidade dos emigrantes asiáticos. Ou seja, mostra-se solidário ao sofrimento dos chineses na ilha de Cuba e defende melhores condições para os mesmos. No entanto, em sua avaliação geral da emigração, Eça começa a se mostrar contrário à ideia de trazer os trabalhadores asiáticos à América espanhola. Nessa explanação aparentemente contraditória, o escritor se utiliza de argumentos que transparecem um pensamento fortemente eurocêntrico, baseados na caracterização do meio, momento e raça, influência de Taine que Elza Miné destaca em Eça de Queirós Jornalista (1986, p. 104-105).

O futuro romancista usa as experiências dos Estados Unidos e da Austrália como exemplos de fracasso da inserção de mão de obra chinesa para justificar sua postura. Argumenta que tanto na América do Norte quanto na colônia inglesa da Oceania o excesso de trabalhadores chineses e suas sociedades fechadas causaram atritos com as populações locais a ponto de proibirem a ida de emigrantes do império asiático. Destaca ainda que na Austrália a proibição foi cassada, mas que a colônia chinesa que se formou no país era mal vista (QUEIRÓS, 2000a, vol. 3, p. 2079). O nosso autor ainda expõe que não se devem apenas os problemas à quantidade e à reclusão dos chineses: "mais sóbrios mais econômicos que o europeu, faziam-lhe uma concorrência terrível, oferecendo seu trabalho por preços diminutos" (QUEIRÓS, 2000a, vol. 3, p. 2079). Vemos que, para Eça, há não só o atrito cultural, mas também há um desequilíbrio 
econômico. Quando transferida essa situação a Cuba, Eça prevê não a expulsão dos chineses, mas, devido ao "sangue espanhol", atos mais violentos contra os imigrantes na ilha. (QUEIRÓS, 2000a, vol. 3, p. 2080).

E, por fim, emite seu parecer:

De resto é incontestável que o chino inspira uma aversão instintiva à nossa civilização superior. É necessário vê-lo, em grupos, nos seus bairros para se compreender a hostilidade universal. Uma colônia china suja, mancha, desmoraliza uma cidade. Os casebres imundos em que vivem em aglomerações de 800 e 1000, na promiscuidade e no deboche, a sua sociedade sem mulheres, o seu traje sórdido, a sua fisionomia lívida viscosa e astuta, o seu ar desconfiado e avaro, a sua língua áspera e inacessível, tudo provoca, nas nossas ideias cultas e refinadas, um retraimento geral (QUEIRÓS, 2000a, vol. 3, p. 2081, grifo nosso).

O trecho acima, mais uma vez, dialoga paradoxalmente com a primeira parte analisada do texto. Aqui se fortalece a visão eurocêntrica em voga na época em que há a dicotomia "Europa Superior x Ásia Inferior" ou "Europa culta x Ásia bárbara". O texto prossegue:

A emigração asiática em si, creio, não pode dar senão maus resultados. Em primeiro lugar a formação na sociedade europeia, de uma sociedade asiática, com a sua religião própria, a sua língua especial, os seus costumes diferentes, vive fatalmente isolada. A heterogeneidade das raças não comporta fusão. Esta sociedade, suportada com resignação, vigiada com desconfiança, não tem interesse algum na civilização que a cerca: é uma força bruta que serve para produzir riqueza. Além disso as classes que a aproveitam, preocupam-se muito com o vigor dos seus braços, - e nada com o estado do seu espírito: não se emprega um único esforço para dar ao chino ou ao índio uma civilização superior: nada lhe ensina, nem nossa língua, nem a nossa moral, nem a nossa ciência, nem nossos processos industriais: trata-se como uma máquina. [...] $\mathrm{A}$ emigração asiática tem além disso o vício supremo de ser exclusivamente masculina - a mulher índia não emigra; a chinesa está fatalmente fixa à casa, à aldeia, pela desorganização sistemática dos pés. Esta sociedade celibatária de uma raça lasciva, sob um clima excitante, produz nas cidades onde existe um deboche habitual e degradante. Não só a raça trabalhadora se debilita pelos excessos antinaturais, mas ganha na privação das mulheres aquele caráter covarde traiçoeiro, descontente, irritado (QUEIRÓS, 2000a, vol. 3, p. 2082, grifo nosso)

Na oração destacada do trecho acima, vemos o escritor argumentando sobre a falta de empenho em ensinar ao asiático a cultura europeia. Embora aqui, ainda, se veja 
um argumento unilateral no qual a Europa deve ensinar sua "civilização superior" não tendo, por dedução lógica, nada a aprender com o Império asiático, já observamos um ponto que julgamos ser fundamental nos textos de Eça da década de 90: a questão do aprendizado. Aqui parece ser umas das primeiras manifestações deste ponto de vista nos seus textos não ficcionais. $\mathrm{O}$ fato de nada ensinar com a experiência de conviver com o "outro" parece já aqui como um incômodo para Eça. E, conforme notaremos com a análise de textos posteriores, tal posição continuará e se aprofundará ao longo de sua vida.

Conclui, enfim, resumindo seus argumentos:

Cuba resume com o seu exemplo toda a argumentação contra a emigração assalariada: [...] Elevou, é verdade, a sua produção; mas a custa de quantas desvantagens: criou uma sociedade asiática numerosa, hostil, despeitada, que só trabalha forçada e só se contêm pela folia dos regimentos: teve de seguir para esta colônia um sistema de vexações e de tiranias, que lhe tem trazido as antipatias universais: tem afastado toda emigração livre, e seu concurso civilizador: tem visto o deboche e a desmoralização penetrar nas plantações com a introdução dos coolies, [...] viu proprietários habituarem-se ao trabalho braçal dos coolies, e desprezarem as máquinas e os novos sistemas científicos de cultura: viu sua produção inteiramente dependente da emigração: e de repente pela falta imprevista dessa emigração a sua produção comprometida (QUEIRÓS, 2000a, vol. 3, p. 2083)

Portanto, em A Emigração como Força Civilizadora, Eça parte de uma denúncia ou de, pelo menos, percepção das más condições dos chineses na ilha cubana, a uma militância contra a entrada desses trabalhadores nas colônias europeias. Como justificativa dessa aparente mudança de postura, o autor destaca dois problemas: um econômico e um cultural. Mas também argumenta sobre a "desmoralização" de um local que recebe o trabalhador chinês, além da interrupção do progresso científico. Apesar de o nosso autor não falar diretamente, não poderíamos inferir a comparação entre emigrantes europeus e emigrantes chineses, sendo o primeiro visto de maneira positiva e o segundo negativa? 
Ao pensarmos em datas e na biografia do autor, podemos começar a conjecturar justificativas para tais pontos de vistas. As ideias de Proudhon influenciaram fortemente Eça quando jovem, que o lia já desde os tempos de estudante em Coimbra (CAMPOS MATOS, 1988, p. 517). Por outro lado, em 1874 as ideias de Taine e do positivismo ainda se mostravam muito presentes em seu modo de enxergar o mundo e a $\operatorname{arte}^{41}$. Lembramos ainda que a essa época Eça ainda não tinha publicado a primeira versão de $O$ crime do Padre Amaro (1875). Ou seja, estamos lendo um Eça de Queirós que ainda está se formando intelectualmente. Portanto parece-nos lícito supor que Proudhon de certo modo influenciou o engajamento e o trabalho de Eça em prol dos coolies, enquanto os pensamentos sobre meio, raça e momento de Taine serviram como guia de seus argumentos contra a entrada de chineses como trabalhadores livres. João Gaspar Simões (1973, p. 297), ao analisar a participação de Eça nas Conferências do Casino Lisbonense de 1871, destaca a coexistência dessas duas concepções na ideia de realismo do jovem escritor português. Parece-nos que, aqui também, as ideias dos dois pensadores franceses estão presentes no raciocínio apresentado nesse relatório.

Para finalizar nossa incursão por este texto, gostaríamos de destacar a importância que este documento consular elaborado por Eça teve em seu tempo. Conforme destaca Monica Simas: “o relatório de Eça causou grande impacto no conjunto de medidas que buscavam resgatar a emigração livre, tentando evitar conflitos com a Inglaterra e a China" (SIMAS, 2007, p. 97). Citando um estudo de Basto da Silva $^{42}$ e um documento de Andrade Corvo ${ }^{43}$, Simas demonstra que "seu relatório [...] influenciou diretamente as avaliações do ministro do Ultramar [...]” (SIMAS, 2007, p.

\footnotetext{
${ }^{41}$ A influência de Taine aparece em diversos momentos do relatório em termos como "sangue espanhol" (p. 2080), "aversão instintiva" (p. 2081), "clima excitante" (p. 2082) ou "antipatias universais" (p. 2083). ${ }^{42}$ SILVA, B.B. Emigração de cules. Dossier Macau - 1851-1894. Macau: Fundação Oriente, 1994.

${ }^{43}$ CORVO, J. A. Estudos sobre as províncias ultramarinas. Lisboa: Academia Real das Sciencias de Lisboa, 1887.
} 
98). Deste modo, pode-se ver que este texto queirosiano teve sua relevância, não só em sua literatura - como veremos -, mas nas decisões políticas de seu país.

Posto isto, podemos avançar em nosso estudo. Adentraremos, a partir de agora, os textos de imprensa queirosianos. Começaremos por dois textos publicados em As Farpas, ambos do ano de 1871, três anos antes da redação desse relatório.

\subsection{O EXTREMO-ORIENTE EM UMA CAMPANHA ALEGRE (TEXTOS D'AS FARPAS)}

As Farpas foram folhetos mensais publicados a partir de junho de 1871 - mas datado de maio de 1871 (MEDINA, 1988, p. 261) - assinados por Ramalho Ortigão e Eça de Queirós. Este último autor colaborou n'As Farpas até 1872, quando tomou posse em Havana como cônsul português ${ }^{44}$. Posteriormente, as crônicas escritas por Eça foram reunidas e publicadas sob o título de Uma Campanha Alegre (1890-1891). Dos inúmeros textos queirosianos escritos e publicados nesses folhetos, pouquíssimos abordam o Extremo Oriente. Na realidade, nenhum dos temas tratados por Eça é o Oriente em si. Isso é um tanto coerente, uma vez que o objetivo dos textos de As Farpas era fazer a "análise da vida social [...] funcionalizando o cómico, a ironia e o grotesco ao serviço da renovação da sociedade portuguesa" (GROSSEGESSE, 2005, p. 149). João Medina diz que "as suas Farpas constituem um sistemático e quase que completo curso da sociologia do Portugal da Regeneração" (MEDINA, 1988, p. 264). Portanto, quando o Oriente aparece, surge como objeto de interesse à sociedade portuguesa da metrópole. O que poderia interessar à "renovação da sociedade portuguesa" nos anos 70 do século XIX era a relação da metrópole com suas colônias. Logo, o Oriente presente n’As Farpas é o das possessões portuguesas no Extremo Oriente.

\footnotetext{
${ }^{44}$ Já Ramalho Ortigão continuou publicando sozinho As Farpas até 1882.
} 
A questão das colônias aparece em dois textos: o primeiro é o texto número XVIII d'As Farpas, de julho de 1871 que, recebeu posteriormente o título de "A Marinha e as Colônias". Neste texto, Eça trata brevemente da colônia portuguesa na China, Macau. No entanto, sua verdadeira crítica está no estado em que a Marinha portuguesa se encontrava na época. O segundo texto, de setembro do mesmo ano, trata de uma revolta acontecida na colônia portuguesa de Goa, na Índia. Este texto aparece como o texto número XXXIV, de acordo com a edição das Obras Completas de Eça de Queirós organizada por Beatriz Berrini (2000).

A pouca diferença temporal entre esses dois textos faz com que as ideias nelas expressas sejam bastante semelhantes. Eça advoga a favor da venda dessas terras ultramarinas, uma vez que não enxerga nenhum benefício econômico ao seu país. Criticando o sistema colonial implantado pelos lusitanos, não só Eça, mas a Geração de 70 como um todo, reconhece o papel fundamental das colônias no passado português, mas não veem espaço para elas no futuro da nação ${ }^{45}$.

Portanto, parece claro que "o anticolonialismo dessa geração é abstencionista e nada tinha a ver com motivações humanitárias (aliás, nesta altura, o colonialismo é que era, de certo modo, considerado um movimento humanitário)” (RAMOS, 2001, p. 67).

Eça inicia o texto de julho de 1871 tratando de um "pânico patriótico" (QUEIRÓS, 2000a, vol. 3, p. 720) em Portugal devido à notícia de uma possível perda

\footnotetext{
${ }^{45}$ Esta ideia de ruptura com o passado é um dos principais alicerces das ideias da Geração de 70. Para ilustramos, utilizamos três passagens do discurso das Conferências do Casino Lisbonense proferido por Antero de Quental em 27 de maio de 1871, intitulado "Causas da decadência dos povos peninsulares nos últimos três séculos". Nas primeiras palavras do discurso, o autor de Odes Modernas, diz: "Há em nós todos uma voz íntima que protesta em favor do passado, quando alguém o ataca: a razão pode condená-lo: o coração pode absolve-lo. É que nada há no homem mais delicado, mais melindroso do que as ilusões: e são as nossas ilusões o que a razão crítica, discutindo o passado, ofende sobretudo em nós" (QUENTAL, 1982, p. 256). No meio de sua fala, é dito: "Esse moribundo que se ergue dentro em nós, é o inimigo, é o passado. É preciso enterrá-lo por uma vez, e com ele o espírito sinistro do catolicismo de Trento" (QUENTAL, 1982, p. 282). E, já nas conclusões de seu raciocínio, Antero profere: "É necessário um esforço viril, um esforço supremo: quebrar resolutamente com o passado. Respeitamos a memória de nossos avós: memoremos piedosamente os actos deles: mas não os imitemos. Não sejamos, à luz do século XIX, espectros a que dá uma vida emprestada o espírito do século XVI”. (QUENTAL, 1982, p. 294).
} 
da colônia de Macau. O farpista abre seu texto com as seguintes palavras: "Houve este mês um pânico patriótico: julgou-se que íamos perder Macau! A China, segundo se afirmava, tinha intimado Portugal a evacuar aquela colônia - onde só devia reinar o rabicho" (QUEIRÓS, 2000a, vol. 3, p. 720). A possível perda de Macau a qual Eça se refere vai ao encontro de um dos dois problemas que Portugal enfrentou em sua colônia chinesa: "afirmar plenamente a soberania portuguesa sobre o território, objetivo projetado desde os finais do século XVIII, mas nunca consumado até à data [...]" (SERRÃO, José, 1998, p. 722). O outro problema, de acordo com José Vicente Serrão, estava em "encontrar alternativas econômicas susceptíveis de travar a decadência que se acentuava” (SERRÃO, José, 1998, p. 722). Esta decadência aconteceu não só pelas questões políticas ocorridas na metrópole desde o início do século XIX, mas também por causa da Guerra do Ópio (1839-1842) que originou a colonização inglesa em Hong Kong e abriu o mercado chinês à Inglaterra ${ }^{46}$ (SERRÃO, José Vicente, 1998, p. 722723). Embora não trate especificamente dessas questões, as críticas de Eça estão diretamente envolvidas com o momento passado pela colônia portuguesa de Macau no ano de 1871.

Retornando ao texto "A Marinha e as Colônias", o farpista logo expõe como enxergava a relação da metrópole e seus domínios na Ásia: “As relações de Portugal com as suas colônias são originais. Elas não nos dão rendimento algum: nós não lhes damos um único melhoramento: é uma sublime luta - de abstenção" (QUEIRÓS, 2000a, vol. 3, p. 721). Deste trecho destacamos duas questões: a crítica à política colonial portuguesa e à questão de ensinamento que destacamos no tratado $A$ Emigração como Força Civilizadora. A crítica ao sistema colonialista português se dá no sentido de Portugal não explorar as terras que possui. Ou seja, não há nenhum

\footnotetext{
${ }^{46}$ Desta guerra, Eça tratará no artigo “Chineses e Japoneses” de 1894, conforme veremos.
} 
proveito econômico em manter as terras na China. Da questão do aprendizado, essa crítica se dará, como no relatório três anos posterior, de maneira unilateral: ou seja, não se ensina nada ao colonizado. Eça n’As Farpas parece não enxergar, ainda, o Outro enquanto ser detentor de conhecimento e, consequentemente, passível de ensinar. Em outras palavras, parece não ver a possibilidade de aprender com o Outro, conforme assinalamos na análise do relatório.

Aqui, podemos aproximar, mais uma vez, a visão de Eça de As Farpas com o discurso de Antero de Quental proferido no Casino Lisbonense naquele ano. Em “Causas da decadência dos povos peninsulares nos últimos três séculos”, é dito:

As conquistas romanas são hoje justificadas pela filosofia da história, porque criaram uma civilização superior àquela de que viviam os povos conquistados. A conquista da Índia pelos Ingleses é justa, porque é civilizadora. A conquista da Índia pelos Portugueses, da América pelos Espanhóis, foi injusta porque não civilizou. Ainda quando fossem sempre vitoriosas as nossas armas, a Índia ter-nos-ia escapado, porque assistematicamente alheávamos os espíritos, aterrávamos as populações, cavávamos pelo espírito religioso e aristocrático um abismo entre a minoria dos conquistadores e a maioria dos vencidos (QUENTAL, 1982, p. 292).

Logo, o que se vê, tanto no discurso de Antero, quanto neste ponto da crônica de Eça é uma ideia eurocêntrica fortemente marcada, em que a Europa, detentora de uma sociedade "superior", tem como obrigação "civilizar" suas colônias, lugares vistos, consequentemente, como "bárbaros".

Eça prossegue seu texto mostrando que o abandono não é exclusividade da relação Lisboa-Macau. O autor ironiza a relação da metrópole lusitana com outras colônias e com os Açores, "que não são uma colônia, mas que pela distância, pelo abandono, pela separação de interesses, têm toda a fisionomia colonial..." (QUEIRÓS, 2000a, vol. 3, p. 721). Chega, enfim à crítica à marinha portuguesa: "Mas, meus senhores, antes de tudo, nós não temos marinha!” (QUEIRÓS, 2000a, vol. 3, p. 722). Faz um panorama extremamente cômico da situação da Marinha portuguesa até ligar 
esta força naval decadente com o abandono das colônias por parte do governo português. "Com tal marinha como podem as colônias prosperar?" (QUEIRÓS, 2000a, vol. 3, p. 724). Assim, já ao final do texto, defende a venda das colônias como solução para o momento econômico vivido por Portugal. Cito: "Para que temos colônias? [...] Sejamos vilmente agiotas, como compete a uma nação do século XIX - e vendamos as colônias” (QUEIRÓS, 2000a, vol. 3, p. 725-726). Aqui podemos destacar o início de uma visão crítica à política colonialista europeia, em que se liga essa prática à agiotagem. Demonstra enxergar, ainda sem a complexidade que demonstrará nos anos posteriores, o verdadeiro fim dessa política. Na conclusão, jocosamente recua de sua sugestão a fim de ironizar a administração lusitana: "Dilema pavoroso! Devemos vender as colônias porque não temos governo que as administre; mas não as podemos vender porque não teríamos governo que administrasse o produto! Miserere" (QUEIRÓS, 2000a, vol. 3, p. 726).

Apesar de tratar da possessão portuguesa em território chinês, o autor não descreve esta colônia, nem parece interessado em sua cultura. Não há qualquer julgamento de seu povo, nem parece haver preocupação com esta região do planeta que ultrapasse a crítica feita à política da metrópole. Inclusive o abandono com que é retratada também é culpa do governo português. O que se destaca fortemente deste texto é o início de uma crítica ao aprendizado, presente também em A Emigração como Forção Civilizadora, que irá se desenvolvendo ao longo dos anos - como veremos nos textos da década de 90 - e a ideia da inutilidade das colônias asiáticas. Essas ideias estarão também presentes no texto de setembro de 1871. Aqui, no entanto, Eça desenhará um retrato da colônia de Goa.

O título do texto de setembro de 1871, "História Pitoresca da Revolta da Índia”, já ilustra como Eça de Queirós enxerga a colônia na Índia. Embora classifique de 
“pitoresca" a revolta, não será de outra maneira que a Índia Portuguesa será retratada.

Sempre com o intuito de corroborar a ideia da inutilidade das colônias asiáticas para a sociedade portuguesa da segunda metade do século XIX, Eça traça o tempo todo a revolta, e, consequentemente, a colônia como insignificante. O texto se inicia de modo semelhante a "A Marinha e as Colônias":

Andávamos inteiramente esquecidos da Índia! Uma clara manhã ela aparece violentamente no meio de nós, envolta num telegrama do sr. visconde de S. Januário. Por essa ocasião muito bom português se admirou que a Índia ainda fosse nossa! [...] Uma vez que a gloriosa Índia ainda existia, era necessário que a respeito dela existisse o correspondente brio patriótico. Sacudiu-se o velho brio patriótico do pó e da caliça - e cada um envergou o velho brio patriótico! (QUEIRÓS, 2000a, vol. 3, p. 750)

Assim como em julho, neste texto de setembro de 1871, também é referido do movimento patriótico despertado nos portugueses com a chegada da notícia de uma rebelião iniciada em Goa. Esta revolta aconteceu devido à extinção do exército goês, principal fonte de emprego dos habitantes da colônia. Ernestina Carreira explica-nos a situação:

[...] quando foi remodelada a administração ultramarina, a Índia foi a única província a obter (com Angola) uma Junta Geral de Província. Esta [...] compunha-se de autoridades metropolitanas, mas também de vogais propostos pelas municipalidades. [...] Por isso, o médico e veterinário português António Lopes Mendes pôde escrever, nos anos de 1860 , que os nativos se consideravam os 'legítimos senhores da terra'. Eles ocupavam agora todos os cargos coloniais, menos os de governador, arcebispo e presidente da Relação, reservados aos metropolitanos. Puderam até adquirir títulos de nobreza, outorgados pelo rei. $\mathrm{Na}$ realidade, essa ascensão implicava o sacrifício progressivo dos interesses da comunidade descendente. As reformas administrativas e financeiras impostas pelo governo português e aplicadas por Pestana em 1869 exigiam uma diminuição do exército que continuava a absorver mais de metade dos rendimentos da receita da colônia, sem grande proveito, fora o de manter empregos. Compunha-se então de 3000 homens, repartidos em quatro batalhões, um regimento de artilharia e um corpo de guarda municipal. A reestruturação previa um aumento de $50 \%$ dos salários dos oficiais metropolitanos, mas suprimia as vagas de oficiais e oficiais inferiores, o que eliminava qualquer possibilidade de promoção. Em Fevereiro de 1870, os batalhões revoltaram-se. [...] O governador Pestana aceitou negociar, concedeu-lhes a amnistia e um salário equivalente ao dos oficiais portugueses. Foi destituído por causa dessas decisões. Reprovando estes atos de indisciplina, a metrópole ordenou a 
dissolução do exército goês, pelo decreto de 11 de novembro de 1870 . Um ano depois, em setembro de 1871, os batalhões revoltaram-se de novo. (CARREIRA, 1998, p. 673-674).

Embora este episódio tenha sido de grande relevância para a história de Goa, Eça, com seu pensamento centrado na metrópole, classifica essa revolta como “insignificante e efêmera como um meeting civil no reino" (QUEIRÓS, 2000a, vol. 3, p. 751).

A seguir passa a caracterizar o recém-extinto exército indiano. Entretanto, o desenho dos membros inferiores do batalhão é o reflexo de como Eça enxergava toda a sociedade goesa. Como vimos no texto anterior, o objetivo do farpista é demonstrar como as colônias asiáticas não trazem nenhuma vantagem econômica a Portugal. Assim, toda a caracterização do povo indiano se dá de maneira irônica e pitoresca a fim de rebaixar a população oriental da colônia portuguesa e, deste modo, legitimar seu discurso de inutilidade desta. Cito :

O grosso do exército da Índia é composto de indígenas - mouros, canarins, banianos e gentios. Estes nomes melodiosos designam castas; e as castas na Índia conservam ainda todo o seu velho e irreconciliável separatismo. As castas desprezam-se, guerreiam-se, e nunca absolutamente se fundem. Quase não se comunicam (QUEIRÓS, 2000a, vol. 3, p. 751).

Quando o autor diz de "velho e irreconciliável separatismo" não poderíamos inferir uma caracterização da sociedade indiana como "velha" e, por inferência, antiga, pertencente ao passado, em contraposição à sociedade europeia, moderna, representante do futuro? Futuro esse desejado por Eça para Portugal?

A ironia da caracterização dos orientais continua quando diz: "Além disto, todas as castas têm hábitos fatais, horas impreteríveis”. (QUEIRÓS, 2000a, vol. 3, p. 751).

Destaca-se numa frase escrita pouco após essa caracterização em que o farpista diz: "Ora os oficiais índios, com um zelo pelas rupias extremamente compreensível, quereriam ter um soldo igual aos oficiais que vão de Portugal. Por consequência 
requerem. (Têm a ingenuidade asiática de requerer!)” (QUEIRÓS, 2000a, vol. 3, p. 751). Ao dizer “ingenuidade asiática de requerer”, Eça está falando diretamente a principal característica com que define a população de Goa e os portugueses que ali vivem: "ingênuo". A ideia do oriental ingênuo e passivo, uma das imagens comuns na Europa oitocentista é a única a ser fortemente destacada pelo futuro autor de Os Maias. Como veremos adiante, Eça não chega a perder completamente essa imagem ao longo de sua vida. Mas, definitivamente, não se limitará a essa.

Vemos novamente a passividade ligada ao Oriental no seguinte trecho:

Pois bem! Ainda assim uma revolta na Índia não tem seriedade. [...] Os soldados não vão por impulso próprio. Divididos em castas, fracos, ignorantes, odiando-se, sem terem interesse comum ou vontade comum - vão unicamente porque os seus oficiais, no primeiro momento, lhes mandaram que fossem (QUEIRÓS, 2000a, vol. 3, p. 752).

Essa caracterização irônica prossegue por mais alguns parágrafos até definir diretamente o habitante indiano da colônia portuguesa. Nas descrições físicas do indiano, também redutivas, vemos características como débil e fraco, portanto pouco proveitoso para o trabalho em uma colônia:

O índio de nossas possessões é de uma debilidade gelatinosa. Anêmico, miudinho, assustadiço, consumido pelo sol, mal sustentado de arroz, o índio cai de bruços com uma carícia no rosto, e morre com uma palmada na espinha. [...] Um empurrão, e o índio tomba - na eternidade. Não há talvez desembargador algum em Goa que não tenha, com a sua mão grave e jurídica, assassinado um índio! [...] (QUEIRÓS, 2000a, vol. 3, p. 753).

Adiante, caracteriza, de maneira semelhante ao habitante indiano, o solo pertencente a Portugal:

E um pedaço de terra tão escasso que se anda a cavalo num dia. As pequenas povoações caem em ruína e em imundície; não há nelas movimento, nem iniciativa; a única cultura é o arroz, que exportam a 5 para importar a 8; a única indústria, fazer olas, que são os encanastrados de palmeira com que se erguem os pacaris, alpendres coloridos e frescos que sombreiam as janelas; não existe nenhum comércio; os tributos esmagam; dois ou três homens ricos, Jossy e mais dois, que se vêem nos patins, descalços e encruzados, comendo o seu arroz com a mão, têm o dinheiro enterrado, e quando se lhes 
garante um forte juro, cavam e emprestam; as escolas são uma ficção grotesca; as estradas são a espessura do mato; a higiene é feita pelos cães que lambem as imundícies na rua; a polícia é feita por cada um com o seu bambu; uma intriga sórdida e rastejante agita indígenas e europeus; o deboche tem o ardor do clima; os soldados embebedam-se com aguardente; e no entanto velhos pardieiros, que se esboroam às mordeduras do sol, esconderijos de corvos, lembram as nossas glórias e alastram o chão de caliça. Tal é a Índia Portuguesa (QUEIRÓS, 2000a, vol. 3, p. 754).

Algumas ideias desse parágrafo, mais uma vez, são próximas às apresentadas no discurso anteriano de maio de 1871. Lá, ao falar do sistema colonial português desde a segunda metade do século XVI, o "líder" da Geração de 70 havia dito:

Não se fabrica, não se cria: basta o ouro do Oriente para pagar a indústria dos outros, enriquecendo-os, instigando-os ao trabalho produtivo, e ficando nós cada vez mais pobres, com as mãos cheias de tesouros! Importávamos tudo: de Itália, sedas, veludos, brocados, massas: de Alemanha, vidro: de França, panos: de Inglaterra e Holanda, cereais, lãs, tecidos. Havia então uma única indústria nacional....a Índia!"' (QUENTAL, 1982, p. 289).

A Índia aparece na sequencia do discurso como local onde os portugueses iam enriquecer e voltar à Lisboa para "gozar, dissipar esterilmente.” (QUENTAL, 1982, p. 289). Ou seja, a ideia é próxima ao que Eça profere em setembro, ao falar da falta de aplicação de recursos em Goa.

Já nos últimos parágrafos do texto traça uma comparação entre a colonização inglesa e portuguesa na Índia. A finalidade desta comparação, como é bastante dedutível, é criticar a política portuguesa. Ao dizer que uma verdadeira revolta indiana aconteceria se os ingleses tentassem invadir Goa, Eça ironiza:

[...] no nosso regime ele vive na ociosidade, no desleixo, na sua imundície querida, na sua bem-amada traficância; e se fosse inglês, o cipaio viria a obrigá-lo a golpes de courbach, a ser policiado e a ser trabalhador. E o soldado índio detesta o inglês - porque, sob o nosso regime, ele pode subir os postos até major; e sob o regime inglês não subiria nem a cabo (QUEIRÓS, 2000a, vol. 3, p. 754).

É interessante notar que, para criticar a política portuguesa, Eça parodia também o discurso orientalista britânico, exposto por Edward Said em diversos momentos de seu 
Orientalismo $^{47}$. Assim, mesmo que aparentemente involuntária, se apresenta, sob a forma da paródia, uma crítica a diferentes métodos colonialistas europeus do último quartel dos Oitocentos.

Após vários parágrafos ironizando a colônia de Goa, suas terras, suas pessoas e seus colonizadores, Eça remonta ao texto de julho do mesmo ano quando defende a venda das colônias asiáticas. Aqui, porém, vai mais longe. Sugere que o prejuízo que Goa proporciona a Portugal é tão grande que recomenda a doação das terras indianas: "Noutro número das Farpas lembramos, a respeito das colônias, este grande melhoramento - vendê-las! Ocorre-nos outro ainda maior a respeito da Índia - dá-la" (QUEIRÓS, 2000a, vol. 3, p. 754). E finaliza ligando a colonização na Ásia com o passado, devendo assim ser preservado. Mas destaca a ausência de espaço no futuro da sociedade portuguesa: “A única coisa por que conservamos a Índia, é por ser uma glória do passado. [...] O passado é belo e heróico - bem: quando o passado pretende anteporse aos interesses do presente, o passado é caturra!” (QUEIRÓS, 2000a, vol. 3, p.755) ${ }^{48}$.

Vistos de um modo mais amplo, percebe-se que nesses textos de As Farpas, apesar de pouco tratarem do Extremo Oriente, as ideias trabalhadas são muito semelhantes. Como lembramos no início deste tópico, o principal motivo pelo qual Eça trata dos domínios no extremo asiático é para indicar sua venda. Com isso enquanto objetivo, toda a caracterização, quando acontece, se dá de maneira negativa a fim de corroborar sua proposta. Uma visão por vezes etnocêntrica de um Eça jovem, em formação intelectual que sonhava com a renovação da sociedade portuguesa.

Como parece ter ficado claro, a esta época, Eça e seus companheiros de geração participavam das Conferências do Casino Lisbonense e, por isso, suas preocupações estavam no atraso intelectual na metrópole portuguesa. Deste modo, as ideias aqui

\footnotetext{
${ }^{47}$ Cf., por exemplo, SAID, 2008, p. 305-341.

${ }^{48}$ Mais uma vez poderia se relacionar este trecho com o discurso de Antero. Cf. nota 45.
} 
expressas em muitos momentos vão ao encontro do que foi proferido, por exemplo, por Antero de Quental em "Causas da Decadência dos Povos Peninsulares nos Últimos Três Séculos". Passado este momento combativo deste jovem do Cenáculo, tendo aparecido “a Vida, enrugada, de dedo ameaçador, a avisar que ela não é musa ou ninfa que se trate com ligeireza, indiferença, e cantando" (QUEIRÓS, 2000a, vol. 3 p. 1774), conforme diz nosso autor em "Um Gênio que era um Santo", o ponto de vista de Eça em relação ao Extremo Oriente mudará. Isto é, não será mais restrito à relação entre metrópole e colônia. Nos próximos textos de imprensa que vamos analisar, todos da década de 90 época, portanto, do grupo "Vencidos na Vida" - vamos verificar como esta perspectiva se modificou, identificando o que há de semelhante e o que há de novo na visão queirosiana do Extremo Oriente vinte anos após a escritura destas "farpas".

\subsection{O EXTREMO-ORIENTE EM ECOS DE PARIS E CARTAS FAMILIARES E BILHETES DE PARIS (TEXTOS À GAZETA DE NOTÍCIAS DO RIO DE JANEIRO)}

Dentre toda a colaboração de Eça de Queirós a jornais e revistas ${ }^{49}$, pode-se dizer que o material enviado à Gazeta de Notícias do Rio de Janeiro está entre "o conjunto mais representativo" (MINÉ, 2000a, p. 15) de sua produção para imprensa. Este jornal, de acordo com Elza Miné, “jornal ágil e vibrante” (MINÉ, 2000a, p. 33), era consumido pela parcela progressista da população carioca, "pois a fatia mais conservadora, em termos de Rio de Janeiro, se voltava para o Jornal do Comércio, considerado o mais sisudo da época, [...], preferido pelos ‘caixeiros’ do Rio” (MINÉ, 2000a, p. 33).

A este jornal brasileiro, Eça enviou não apenas crônicas, mas também diversos trechos de sua ficção. De acordo com o levantamento de Elza Miné, lá foi publicado $A$ Relíquia (1887); o capítulo final de Os Maias (1888); de A Correspondência de

\footnotetext{
${ }^{49}$ Para citar apenas alguns, temos Diário de Notícias, Gazeta de Portugal, Distrito de Évora, a Revista de Portugal (periódico dirigido por Eça), Revista Moderna, entre outros.
} 
Fradique Mendes, as cartas “A Visconde de A. T.", “A Mme de Jouarre” (segunda carta), "A Oliveira Martins", e as quatro cartas "A Clara"; e os contos Civilização (1892), O Tesouro (1894), Frei Genebro (1894) e O Defunto (1895) (MINÉ, 2000a, p. 19).

Restringindo nosso escopo ao que nos interessa neste momento, a produção jornalística enviada à Gazeta de Notícias, vê-se que Eça colaborou de maneira irregular durante dezessete anos. O primeiro texto assinado por Eça data de 24 de julho de 1880 e textos (ou trechos) se repetem, mensalmente, até fevereiro de 1882 e, mais esporadicamente, até 24 de outubro de 1882. Durante todo este período, o autor de $O$ Mandarim publica na qualidade de correspondente do jornal na Inglaterra.

A produção jornalística de Eça neste periódico fica interrompida por aproximadamente dez $\operatorname{anos}^{50}$, quando, em janeiro de 1892, sai o artigo "A Europa em Resumo". A partir de então, o já cônsul português em Paris publica regularmente crônicas até setembro de 1897, momento que encerra sua participação neste jornal. (MINÉ, 2000a, p. 18-19).

A produção queirosiana ao jornal carioca foi reunida, postumamente, em diversas obras. Há crônicas espalhadas entre os títulos: Cartas da Inglaterra (1905); Ecos de Paris (1905); Cartas Familiares e Bilhetes de Paris (1907); e Notas Contemporâneas (1909). Em 2002, toda a produção jornalística foi reunida no volume Textos de Imprensa IV da Edição Crítica das Obras de Eça de Queirós, sob a responsabilidade das professoras Elza Miné e Neuma Cavalcante. Será esta edição crítica que utilizaremos nas citações deste trabalho.

Nosso recorte abrange textos do segundo momento de colaboração de nosso autor, ou seja, artigos publicados a partir de 1892. Os textos que analisaremos a partir

\footnotetext{
${ }^{50}$ Entre 1887 e 1888, Eça publica algumas das ficções anteriormente citadas.
} 
de agora foram coligidos aos livros Ecos de Paris e Cartas Familiares e Bilhetes de Paris. Passemos, então, ao estudo de "A França e o Sião", "Chineses e Japoneses" e "A Propósito da Doutrina Monroe e do Nativismo".

\subsubsection{A FRANÇA E O SIÃO}

O artigo “A França e o Sião” foi publicado em 20 de agosto de 1893 na Gazeta de Notícias do Rio de Janeiro. Portanto temos uma diferença de mais de 20 anos entre os textos publicados em As Farpas, que vimos. Neste período, Eça de Queirós se formou intelectualmente, produziu e publicou algumas de suas principais obras, dentre elas, as três versões de $O$ Crime do Padre Amaro (1875, 1876, 1880), Primo Basílio (1878), O Mandarim (1880), A Relíquia (1887) e Os Maias (1888). Portanto, o Eça de Queirós que vamos encontrar nesses textos já não é o mesmo dos primeiros escritos. O próprio autor escrevera em uma carta endereçada a Ramalho Ortigão datada de 24 de outubro de 1890 a propósito da publicação de Uma Campanha Alegre:

Eu acabo de reler as minhas Farpas: são uma coleção de pilhérias envelhecida que não valem o papel em que estão impressas. Estou hoje tão longe delas e do estado de espírito que as inspirou - que já quase as não compreendo, e, portanto, de modo algum as defendo (QUEIRÓS, 2000a, vol. 4, p. 169).

Apesar de o artigo datar de 20 de agosto de 1893, uma semana antes, no dia 13 de agosto, Eça faz uma introdução ao tema, que é um conflito armado envolvendo a França e o Reino do Sião, atual Tailândia. Portanto, o que vamos analisar aqui como "A França e o Sião" é parte do texto publicado em 13 de agosto e o artigo de 20 de agosto.

Nestas crônicas, Eça traça um "paralelo entre o colonialismo francês e o inglês" (CAMPOS MATOS, 1988, p. 279), que parece ser o grande motivo pelo qual escreve esse artigo. A comparação entre as duas potências europeias envolve a maior parte do artigo. Mas como artifício para chegar até este suposto objetivo, Eça utiliza do conflito bélico ocorrido entre a nação francesa e o reino siamês. Não é nosso objetivo analisar as 
políticas coloniais europeias presentes no texto de Eça. Aqui vamos nos restringir a ver como Eça desenha o reino oriental, que aparece, inicialmente, como estopim de um possível confronto armado entre franceses e ingleses, cada qual para defender seus interesses políticos.

Na primeira abordagem desta questão internacional, Eça apresenta o reino como causa de um possível cenário de guerra:

Há, ao que parece, uma grave, muito grave novidade internacional. A França e a Inglaterra estão arrufadas. Mais: estão franzindo terrivelmente, uma para a outra, o sobrolho e falando com azedume de casus belli.(caso de guerra) [...].Este rompimento de relações entre a França e a Inglaterra tem por motivo o Sião. (QUEIRÓS, 2002, p. 368)

A fim de contextualizar seus leitores Eça apresenta, de maneira irônica, o reino do Extremo-Oriente e seu rei. Em suas palavras, Eça já desvenda o interesse europeu naquela região:

Sião é um reino do Extremo Oriente, muito rico e, portanto, muito apetecível. Tem um rei bastante curioso, segundo se depreende da sua fotografia, porque da cinta para cima anda vestido à chinesa, e da cinta para baixo à Luís XV! [...] Além do seu rei, Sião possui toda a sorte de riquezas naturais, em plantações e em minas. É portanto um delicioso e proveitoso país para possuir. (QUEIRÓS, 2002, p. 368)

Esta é a primeira (e única no texto de 13 de agosto) caracterização feita pelo autor. Nela já podemos perceber, através da ironia, a consciência de que a caracterização das nações vítimas do processo imperialista europeu é feita para legitimar essa prática política. Quando o autor escreve: "é um reino muito rico e, portanto, muito apetecível”, já se percebe que o único interesse europeu em outras regiões do planeta é enriquecer. Ou seja, o que Eça faz neste trecho, e em outros que estão por vir, é desnudar conscientemente através de sua famosa ironia o imperialismo e o colonialismo do velho continente.

Ambas [França e Inglaterra], muito naturalmente, se encontram há anos nesses confins do Oriente, lado a lado, com o olho guloso 
cravado sobre Sião. [...] O animal inconsciente foi posto sobre a Terra para nutrir o animal pensante - e por isso com bois se fazem bifes. Os países orientais são feitos para enriquecer os países ocidentais - e por isso com os Egiptos, os Tunes, os Tonquins, as Cochinchinas, os Siãos (ou Siões?) se fazem para a Inglaterra e para a França boas e pingues colónias. Eu sou civilizado, tu és bárbaro - logo, dá cá primeiramente o teu ouro e depois trabalha para mim (QUEIRÓS, 2002, p. 368-369).

O que Eça faz aqui é expor as linhas gerais da teoria orientalista que Edward Said (2008) conceituará no final do século XX. Recordando, em linhas breves, o principal tópico da obra Orientalismo, Said tenta mostrar, através da análise de vários textos literários, como a representação do Oriente na literatura ocidental serviu para justificar o discurso civilizatório europeu e legitimar o movimento imperialista que operou ao longo dos séculos XIX e XX. A obra de Said data de 1978, ou seja, oitenta e cinco anos depois dos textos de Eça de Queirós. Lembrando que, na década de 1870, Eça trabalhava com dicotomias como Europa culta/Oriente selvagem, metrópole/colônias ou Ocidente civilizado/Oriente bárbaro, é importante ressaltarmos a percepção crítica demonstrada por nosso autor em torno das nações subjugadas pelas potências do velho continente. Assim, ao olharmos para este texto de 1893, fica evidente a mudança crítica que poucos, em sua época, conseguiram ter ${ }^{51}$.

No texto de 20 de agosto, que trata exclusivamente do imbróglio franco-siamês, percebemos que, se no primeiro artigo o Sião aparece caracterizado rapidamente sob o olhar europeu como lugar de enriquecimento, em outras palavras, como uma vítima do imperialismo, aqui, aos poucos, a imagem ganha outras tonalidades. Essa imagem de vítima do imperialismo não desaparece, mas, juntamente com esta, surge outra representação: o oriental "hábil, incansável, pontual, dócil” (QUEIRÓS, 2002, p.543).

\footnotetext{
${ }^{51}$ Para ilustrarmos, citamos o exemplo de Oliveira Martins (1845-1894), historiador, político importante e amigo pessoal de Eça que escreve em "Teoria da História Universal” (1884): "Não podemos tampouco supor que o europeu fique diante da civilização chinesa naquela atitude em que ficou outrora o grego bárbaro perante o Egito, pois além de que nada temos a aprender com a China, é ela que para a sua defesa adota os nossos navios" (MARTINS, p. 14 apud RAMOS, 2001, p. 67, grifo nosso).
} 
Esta caracterização, nas palavras de Orlando Grossegesse, uma "hiper-idealização"

(GROSSEGESSE, 1997, p. 11), será usada para representar o povo siamês.

Eça abre o texto:

A França começou enfim a devorar Sião. Este ingênuo, amável e polido povo recebeu, há quatro ou cinco dias, um ultimato em que era intimado a entregar, sem demora, à França uma imensa porção do seu território e uma não pequena porção do seu dinheiro. Segundo a prudente maneira dos Orientais, o Sião nem consentiu, nem recusou. Com aquela mansidão e humildade que tão própria é de budistas e de fatalistas, replicou que não compreendia bem as exigências da França, que apetecia a paz, e que por amor dela estava disposto a dar algum dinheiro, mas não tanto, e a abandonar algum território, mas não tão vasto. (QUEIRÓS, 2002, p. 371, grifo nosso).

O que vemos, então, são duas representações do Oriente. Mas nenhuma, como sabemos, representa um Oriente "real", ou experimentado. Logo, o que o autor de $O s$ Maias intenciona é dar a seus leitores duas visões que um europeu tem acerca daquela região do mundo. Ou seja, ele trabalha com dois estereótipos: Sião negativo, inferior, animalizado e Sião positivo, "ingênuo, amável e polido"52. Embora opostas, essas duas caracterizações parecem convergir a um mesmo ponto: o Sião enquanto lugar desprotegido, incapaz de se defender. Portanto, está aí, mais uma vez, a crítica à política internacional europeia.

Essas representações se intercalam ao longo da crônica. Por exemplo, no parágrafo seguinte, Eça destaca mais uma vez o primeiro juízo: “os países do Oriente têm uma deplorável fama de duplicidade e falsidade" (QUEIRÓS, 2002, p. 371, grifo nosso), mas logo apresenta o segundo: “e a França, sem se deter em mais explicações

\footnotetext{
${ }^{52}$ Em "Misticismo Humorístico", publicado em 23 de dezembro de 1866 na Gazeta de Portugal posteriormente integrado às Prosas Bárbaras - Eça apresenta uma visão do Oriente próxima a esta. Lá ele dissera: "Todas estas coisas se parecem com sonhos. Mas o que é o sonho? O que são as visões? São as atitudes, fantásticas e desmanchadas que a sombra dá às verdades. Já se pensava assim o poeta Li TaiPé, que escrevia sobre as coisas santas da China, entre porcelanas e lacas, ao sopro dos nenúfares, vestido de sedas amarelas, perfumado de charão - doce, contemplativo, branco diante de um vaso de margaridas" (QUEIRÓS, 2000a, p. 77). Em "A França e o Sião", assim como em textos que ainda analisaremos, esta imagem não corresponde integralmente à visão de Eça. Ela é apresentada como um dos pilares de um pensamento mais profundo acerca da relação Ocidente-Oriente.
} 
com o infeliz Sião, bloqueou-lhe as costas e fez marchar sobre as províncias do interior as suas tropas coloniais da Cochinchina" (QUEIRÓS, 2002, p. 371, grifo nosso)

A crítica à limitação do ponto de vista europeu atinge seu ápice quando o autor fala diretamente:

E uma senhora que ultimamente, num salão, considerava como a coisa mais pueril e mais grotesca que duas nações tão elegantes como a França e a Inglaterra, se batessem por causa de 'bichos tão feios como os siameses' - estabelecia, sem o saber, a verdadeira doutrina do século. (QUEIRÓS, 2002, p. 372)

Não há desmascaramento mais claro: franceses e ingleses são "nações elegantes", enquanto os siameses são "bichos tão feios". E finaliza: “a verdadeira doutrina do século".

Portanto, acreditamos estar clara a consciência crítica de um Eça que consegue ser pouco eurocêntrico em sua exposição. Apesar desse distanciamento que o romancista consegue ter e de sua imagem aparentemente contrária à dos demais europeus, não se trata, obviamente, de uma negação da Europa. Eça parece fazer uma distinção muito clara de política e cultura. Em outras palavras, consegue enxergar criticamente a Europa em suas questões políticas, mas não deixa de admirá-la ou achá-la menos interessante em detrimento às culturas orientais. Para justificar nosso pensamento, lembramos aqui as palavras iniciais de outro texto do próprio Eça, publicado na mesma Gazeta de Notícias em 18 de janeiro de 1892, intitulado "A Europa em Resumo", em que ele diz: "De todas as cinco partes do mundo a Europa, apesar de tão gasta, permanece incontestavelmente a mais interessante”. (QUEIRÓS, 2002, p. 231). A França será sempre seu "paradigma de sofisticação" (GARMES, 2005, p. 55) e, mesmo a criticando, não se trata de uma negação da cultura francesa, mas de sua política. Citamos o estudo da professora Maria Helena Jacinto Santana:

As crônicas de 90 vêm reafirmar, de acordo com a sua especificidade e contextos, a afirmação de independência face à mãe latina anunciada 
já em textos anteriores à chegada do escritor a Paris. [...] Não se trata de negar todo o valor à França - o que seria pouco verossímil num correspondente de Paris - mas de relativizar a sua importância como mito cultural do Ocidente. Seria abusivo pensar que Eça deixou de admirar e mesmo amar a França. O que acontece é que a imagem globalmente negativa transmitida nas crônicas de Paris dialoga com uma outra imagem, cristalizada, anterior. (SANTANA, 1987, p. 240242 apud MINÉ, 2000b, p. 49) ${ }^{53 .}$

Ao final do texto, embora todo o seu discurso até este momento tenha mostrado, através das duas representações do Sião que destacamos, o reino oriental enquanto vítima da política europeia, este também não deixa de ser ironizado e, consequentemente, criticado. Mas, o julgamento ao reino do Sião não se dará no campo cultural. Apesar de desenhá-los com um matiz exótico, não está no exotismo a crítica. Esta, assim como da Europa, se dirige à política absolutista do rei siamês. Cito:

Eu tenho um amigo que esteve nesse pobre Sião, hospedado pelo rei, no palácio, e conta detalhes bem pitorescos.

Todo o reino de Sião pertence ao rei, tão completamente como aí uma fazenda de café pertence ao fazendeiro. O rei é o dono do solo, dos edifícios, dos habitantes e da riqueza dos habitantes. Pode, querendo, doar, hipotecar, trocar ou vender o reino com tudo o que está dentro das fronteiras.

É uma posse agradável. O povo, por seu lado, considera o rei não só como seu dono, mas como seu deus. E a fórmula religiosa (como se disséssemos o artigo da constituição) que define as relações e deveres entre povo e rei é esta: "Do rei o povo recebe a vida, o movimento e o ser”. (QUEIRÓS, 2002, p. 374)

Passa a ironizar o rei, como fez na primeira caracterização, no texto de 13 de agosto. Cito:

$\mathrm{O}$ rei tem um nome imenso, chama-se Prabat-Tomedetch-PraParammdir, etc., etc., etc. Todo ele não caberia em cinquenta linhas. E de cada vez que se fala ao rei (só os nobres gozam esse privilégio) é da etiqueta invocá-lo com o nome todo.

Uma conversa com sua majestade dura assim longas e longas horas, por causa do nome. De facto, a mais laboriosa e pesada ocupação da corte, é pronunciar o nome de el-rei.[...]

$\mathrm{E}$ as suas maneiras têm nobreza. O que o estraga é o seu ilimitado poder, a sua posição de divindade, e a prodigiosa, inverossímil adulação que o cerca. Assim é uma regra (e cumprida com fervor) que todo o siamês que tem uma filha bonita a dê de

\footnotetext{
${ }^{53}$ SANTANA, Maria Helena Jacinto. Imagens da França nas crônicas de Eça de Queirós. Universidade Coimbra, dissertação de mestrado, mimeo., p. 240-242.
} 
presente ao rei. As suas concubinas oficiais excedem em número as de Salomão. São aos milhares. E o rei, apesar de novo, de não contar ainda quarenta anos, já tem cento e oitenta e tantos filhos! Tudo isso, esposas e filhos, vive no palácio, que oferece as proporções de uma vasta cidade. Há ruas inteiras de esposas! Há bairros inteiros de filhos.” (QUEIRÓS, 2002, p. 374)

Notamos que, se antes o rei era troçado como aquele que "da cinta para cima se vestia à chinesa e da cinta para baixo a Luís XV”, agora ele é ironizado pelo tamanho de seu nome. Adiante, pela quantidade de mulheres e filhos. Mas a crítica verdadeira se centra, não na sua figura, que é apenas zombada, mas no seu sistema político: “O que o estraga é o seu ilimitado poder, a sua posição de divindade, e a prodigiosa, inverossímil adulação que o cerca".

O rei ainda é criticado por não conhecer seu reino:

O rei nunca sai do palácio, não conhece o seu reino, mal conhece a sua capital, que é Banguecoque. Quando por acaso dá um passeio, é uma grande festa, uma grande gala. As ruas são aplainadas e areadas; pintam-se as casas de fresco; os canais (porque Banguecoque assemelha-se a Veneza) levam uma rápida limpeza; toda a população se lava, se alinda, se cobre de jóias; e para que não chova, celebram-se preces nos templos (QUEIRÓS, 2002, p. 375)

Quando Eça fala, nas suas últimas impressões do Sião, da cidade de Bangcoc, é a de um lugar sujo e pouco cuidado. Não poderíamos ver aqui a cidade enquanto metáfora da população siamesa abandonada pelo rei, sendo mais uma crítica à política real? Cito: "Depois o rei recolhe, e por muitos e muitos meses Banguecoque recai no usual desleixo e porcaria. Só no palácio há asseio. De resto, o palácio é que é a nação.” (QUEIRÓS, 2002, p. 375).

Vemos, então, nessa descrição final, que, se ao longo do texto Eça criticou a política europeia, ele não é menos crítico ao despotismo siamês. Ou seja, ao final do texto França e Sião são colocados no mesmo patamar. Se a política europeia é ruim e os países militarmente mais fracos são suas vítimas, a política siamesa é igualmente ruim, por abandonar sua população. De um lado vemos a França e a Inglaterra explorando 
territórios orientais; de outro, vemos a realeza siamesa explorando seu povo. No final, todos se equivalem.

Quando Eça de Queirós fala do Sião, ele não esta tratando apenas do reino do sudeste asiático. Aqui, o Sião é a metonímia do Oriente, assim como a França é do Ocidente. Deste texto podemos depreender algumas representações que talvez prefigurem a ideia do Extremo Oriente para o autor português: 1) um Oriente impotente perante a força bélica europeia, o que resulta em uma crítica à política imperialista e colonialista do velho continente; 2) um Oriente idealizado, isto é, um viés positivo presente no imaginário europeu; e 3) um Oriente cercado por governos despóticos, logo, uma crítica ao sistema político adotado pelas nações asiáticas. Desta forma, se revela um olhar crítico tanto a política europeia, como a política asiática. Portanto, parece que Eça constrói esse Extremo Oriente de maneira complexa, pois, se por um lado, claramente, critica o discurso europeu, por outro, não se resume a ser uma voz contrahegemônica.

No próximo item, analisaremos o artigo "Chineses e Japoneses", escrito pouco mais de um ano após "A França e o Sião". Verificaremos, então, se estas imagens se ratificam ou se novas representações nos serão apresentadas.

\subsubsection{CHINESES E JAPONESES}

Publicado em cinco partes, entre os dias 1 e 6 de dezembro de 1894, a crônica “Chineses e Japoneses" é um dos principais, se não for o principal, texto jornalístico escrito por Eça sobre o Extremo-Oriente. Este texto foi “coligido por Luís Magalhães em Cartas Familiares e Bilhetes de Paris, 1893-1896, edição póstuma da Livraria Chardron de Lello \& Irmão, do Porto, em 1907” (CAMPOS MATOS, 1988, p. 146). 
A motivação do correspondente português em Paris do jornal carioca, aparentemente, é a guerra sino-japonesa (1894-1895) pela posse da península coreana. Mas, no final, a verdadeira razão pela qual redige seu texto é apresentada. Diversos assuntos são tratados pelo autor d'Os Maias ao longo dessa longa crônica. Listando alguns dos temas discutidos temos, obviamente, a própria guerra entre o Império do Meio e a Terra do Sol Nascente; a imagem dos europeus acerca dos povos asiáticos; simulação da visão chinesa acerca os europeus; crítica à civilização europeia contemporânea, utilizando-se dessa mesma visão chinesa simulada; a rivalidade entre a China e o Japão; as possíveis consequências da guerra para a Europa; e a questão da emigração chinesa. Em meio a tantos temas e pontos críticos que estruturam os textos, acreditamos ser melhor dividi-los para melhor compreensão. No entanto, propomos uma divisão diferente da publicação. Não vamos tratar os artigos por dia publicado no jornal carioca, uma vez que o texto é uma unidade, mas vamos dividi-lo em duas partes. Coincidentemente, a primeira da nossa divisão corresponde aos trechos publicados nos dias 1, 2 e 3 de dezembro, de acordo com as informações presentes na Edição Crítica das Obras de Eça de Queirós. Textos de Imprensa IV (da Gazeta de Notícias) (2002), organizada por Elza Miné e Neuma Cavalcante. Consequentemente, o que vamos aqui tratar como segunda parte engloba o conteúdo publicado nos dias 5 e 6 do mesmo mês.

A crônica se inicia com uma contextualização do que está acontecendo nas terras do Extremo-Oriente. O autor instrui seu "público duplo: europeu e americano" (GROSSEGESSE, 1997, p. 8) sobre a guerra entre Japão e China pelas terras na Coreia, episódio que ficou conhecido na história como $1^{\mathrm{a}}$. Guerra Sino-Japonesa. Durante essa contextualização, Eça começa a desnudar, com seu estilo irônico e através de "exageros grotescos de informações enciclopédicas” (GROSSEGESSE, 1997, p. 9), o estereótipo 
europeu acerca dos povos envolvidos na questão bélica. Eça apresenta a Coreia a seu público:

O que dele, na Europa, nós melhor conhecemos, por estampas, é a figura dos seus habitantes, homens esguios e graves, de longos bigodes pendentes, que usam o mais extraordinário chapéu [...] muito alto, muito pontiagudo e de abas tão vastas, que sob ele um patriarca pode abrigar toda a sua descendência, os seus móveis e os seus gados. Estes homens falam um chinês mascavado de tártaro, vivem de arroz, e habitam casa rudimentares, feitas de bambu adobe e papel. (QUEIRÓS, 2002, p. 527);

Aproxima a Coreia da China, separando uma classe letrada e uma classe escrava:

Há, como na China, uma classe superior de letrados, mas enxertada sobre a antiga casta nobre de senhores feudais [...] são estes senhores educados sumariamente pelos livros chineses, que, depois de passados seus exames públicos e obtidos seus diplomas escolares, exercem empregos, comandam as forças, governam províncias, escrevem gramáticas, administram a justiça e formam a corte. Todos os outros serviços são feitos por escravos. (QUEIRÓS, 2002, p. 527-528);

Mas, por fim, a isola de qualquer outro povo: "É um país tão silencioso, tão recluso, tão separado de toda a humanidade [...] que no Japão e na China o designam pela alcunha de “País Ermitão””. (QUEIRÓS, 2002, p. 527).

Apenas na caracterização do povo coreano, já se pode perceber, através da ironia, uma crítica à visão europeia, que se torna clara nos parágrafos seguintes, quando Eça mostra que essa região do globo não é, para o europeu mediano, nada além de um "palco teatral [...] voltado para a Europa", nas palavras de Said. (SAID, 2008, p. 113). Cito: "a luta da China e do Japão parece um enredo de mágica, ou o começo de um desses romances alegóricos, que tanto deleitaram o século XVIII” (QUEIRÓS, 2002, p. 528). E continua:

E, com efeito, para o grande público, para todos aqueles que não são profissionalmente diplomatas, sociólogos ou estratégicos, esta guerra entre as duas nações fortes do Extremo Oriente oferece apenas o interesse divertido de uma pantomina militar, passada numa região de fantasia, onde a política é dirigida pelas fadas e os príncipes são picarescos. (QUEIRÓS, 2002, p. 528). 
Aqui, mais uma vez, se mostra clara a consciência de Eça em relação à limitação do enxergar do europeu mediano, como já verificamos em outros textos, como "A França e o Sião" de 1893. Na sequência, Eça persiste na exposição da visão etnocêntrica europeia de maneira cada vez mais direta: "Hoje começamos realmente a compreender (com certas ressalvas) que se possa ser chinês. Mas esses povos da Extrema Ásia, por ora só os conhecemos pelos lados exteriores e excessivos do seu exotismo" (QUEIRÓS, 2002, p. 528). Enfim, passa a caracterizar o chinês e o japonês, de acordo com a visão comum europeia:

Para o Europeu, o Chinês é ainda um ratão amarelo, de olhos oblíquos, de comprido rabicho, com unhas de três polegadas, muito antiquado, muito pueril, cheio de manias caturras, exalando um aroma de sândalo e de ópio, que come vertiginosamente montanhas de arroz com dois pauzinhos e passa a vida por entre lanternas de papel, fazendo vénias. [...]

E o Japonês é ainda para nós um magricela de crânio rapado, com dois enormes sabres enfiados na cintura, jovial e airado, correndo, abanando o leque, dissipando as horas fúteis pelos jardins de chá, recolhendo à casa feita de biombos e crisântemos para se cruzar numa esteira e rasgar o ventre! (QUEIRÓS, 2002, p. 529).

Aproxima-os, como uma maneira de mostrar como todos parecem ser exatamente iguais para os filhos do velho continente:

A ambos concedemos uma habilidade hereditária em fabricar porcelana e bordar a seda. Como por vezes as populaças trucidam os nossos missionários, a esse caráter [...] juntamos também o da ferocidade (QUEIRÓS, 2002, p.529).

A seguir diferencia-os. No entanto, mostra que apesar de suas diferenças, são semelhantes ao olhar estrangeiro:

Porque os chineses não querem ter caminhos de ferro, nem fios de telégrafo [...] são bárbaros. E enquanto os japoneses, que já copiaram as locomotivas e os telefones, só nos parecem que essa civilização importada, macaqueada e mal usada, os torna irreparavelmente grotescos (QUEIRÓS, 2002, p. 529).

Por fim, demonstra uma visão respeitosa das civilizações chinesa e japonesa:

Que por trás do rabicho e dos guarda-sóis de papel, e das caturrices, e de todo o exotismo, existam sólidas instituições sociais e domésticas, uma velha e copiosa literatura, uma intensa vida moral, fecundos 
métodos de trabalho, energias ignoradas, o europeu mediano não o suspeita (QUEIRÓS, 2002, p. 529).

Portanto, desde o início da crônica, até esse momento, através da caracterização dos povos chinês, japonês e coreano Eça encerra uma crítica à visão limitada acerca do oriental pelo europeu, mostrando consciência do que existe por trás daquilo que é normalmente julgado e apresentado por seus concidadãos. Não se trata, entendemos, de uma tentativa de mudança da imagem dos povos orientais perante o público europeu, mas sim de uma crítica ao pensamento europeu que enxerga o Outro como convém aos seus fins políticos. Ou seja, mais uma vez, percebe-se aqui uma crítica ao movimento imperialista, operado principalmente pela Inglaterra e pela França. Poderíamos nos remeter novamente a obra de Edward Said, pois, de novo, as palavras de Eça vão ao encontro da teoria proferida pelo intelectual palestino erradicado nos Estados Unidos, porém julgamos desnecessário. Gostaríamos de destacar, mais uma vez, o Eça de Queirós que se afasta, não só do pensamento expresso nos textos de As Farpas, mas também de alguns de seus contemporâneos ${ }^{54}$.

A crítica à Europa, que até então se dava de maneira irônica através da caracterização dos povos orientais, passa a ser feita de maneira direta, tendo por alvo o pensamento materialista e capitalista como principal causa desse ponto de vista entravado:

Quando uma civilização se abandona toda ao materialismo, e dele tira, como a nossa, todos os seus gozos e todas as suas glórias, tende sempre a julgar civilizações alheias segundo a abundância ou a escassez do progresso material, industrial, e sumptuário! Pequim não tem luz elétrica nas lojas; logo, Pequim deve ser uma cidade inculta. [...] Milhares, se não milhões de europeus não acreditam ainda, verdadeiramente, que os romanos e os gregos fossem povos civilizados, pois não conheciam a máquina a vapor, nem a máquina de costura, nem o piano, nem outras grandezas do nosso grande tempo (QUEIRÓS, 2002, p. 529-530).

\footnotetext{
${ }^{54}$ Cf. nota 51.
} 
Deste modo, o autor de Os Maias utiliza várias estratégias para mostrar sua tese. A crítica que ele faz, utilizando várias visões, é uma só: o europeu não enxerga, por causa de sua política econômica, que há, nas terras do Extremo Oriente, povos com culturas "melhores ou tão boas como a dos ocidentais" (QUEIRÓS, 2002, p. 369). É a mesma proposta apresentada no artigo já analisado neste trabalho "A França e o Sião".

Esse procedimento persiste por mais alguns parágrafos do texto. Eça demonstra a artificialidade da visão europeia acerca da China ao lembrar que poucos europeus adentram o Império asiático e, normalmente, julgam-na pelos trabalhadores dos portos:

Os europeus que habitam e visitam a China acrescentam que eles são, além disso, muito falsos, muito mentirosos, muito covardes, muito larápios e muito sujos. Mas estes europeus, verdadeiramente, da China só conhecem a orla marítima, os portos abertos ao comércio europeu, as "concessões", Hong-Kong e Xangai. E nestes portos só conhecem materialmente aquela populaça chinesa, iletrada e grosseira, que se emprega nos misteres inferiores de barqueiro, carregador, criado, moço de fretes, vendedor ambulante, etc. Ora, avaliar por esta baixa matula toda a sociedade chinesa é como julgar a França pelos maltrapilhos que fervilham nos cais de Marselha, ou criticar o Brasil, e a sua educação, e a sua cultura, e a sua força social, pela gente baixa que carrega e descarrega fardos dos trapiches para os armazéns. (QUEIRÓS, 2002, p. 532).

Prossegue contrapondo a visão europeia expressa no parágrafo anterior com a de alguns europeus que viajaram pelo interior chinês:

Os que [...] se internam pela China, vêm na realidade maravilhados: tendo ido para ensinar os operários chineses [...] confessam que aprenderam na convivência da burguesia culta e letrada, lições de conduta, de ordem, de respeito filial, de profunda união doméstica, de inteligente economia, de trabalho metódico, de subordinação, de pureza, de zelo moral e de toda a sorte de virtudes íntimas, que garantem melhor a grandeza, estabilidade e ventura de uma nação, do que a mais subtil arte em fabricar obuses e manobrar torpedeiros. (QUEIRÓS, 2002, p. 532-533)

Abrimos breves parênteses, aqui, para destacarmos uma imagem fundamental para nosso estudo. Neste trecho supracitado, Eça de Queirós destaca a classe letrada chinesa. Ou seja, já se nota, aí, a divisão da sociedade chinesa em, no mínimo, duas classes: uma classe letrada (e nobre) e, em contraposição, uma classe iletrada, ou seja, a 
classe trabalhadora com que Eça conviveu em Havana. Há uma ligação desta elite letrada ao ensinamento, enquanto se relaciona os operários ao aprendizado. Em outras palavras, a classe letrada é o estrato social que pode ensinar algo ao europeu. Antônio Coimbra Martins, em seu estudo sobre $O$ Mandarim, destaca que a China, no imaginário oitocentista europeu, era representada como "ideal de arte, requinte, fantasia delicada e fino prazer" (MARTINS, 1967, p. 151). Aqui, não podemos ligar essa representação, para Orlando Grossegesse, como já nos referimos, uma "imagem idealizante" ou "hiper-idealização" (GROSSEGESSE, 1997, p. 11), à China como um todo, mas a um grupo social específico. Neste caso, os nobres da elite letrada. Já a classe operária é a que, em contato com os europeus, adquire conhecimento. Assim, eles representam a camada social chinesa que deve aprender com o Ocidente. Deste ponto de vista, parece-nos que para nosso autor a relação Ocidente-Oriente - embora Eça deixe claro que não é o que acontece, nem o que se intenciona - deveria ser pautada em um intercâmbio de conhecimento.

A visão de que a cultura oriental é equiparada a ocidental ganha seu ápice quando o romancista aproxima Paris e Pequim:

Só se queixam da falta de higiene municipal e da porcaria das ruas que [...] são tão mal varridas e tão abundantes em lixo como as de Paris há cinquenta ou sessenta anos, quando já o papá Hugo lhe chama de "cidade radiante", alma do mundo e toda a Europa lhe imitava (QUEIRÓS, 2002, p. 533).

Então, Eça faz, mais uma vez, como no texto de 1893 sobre a França e o Reino siamês, uma crítica direta ao imperialismo europeu, se referindo diretamente sobre os conflitos conhecidos como a guerra do ópio (1839-1842 e 1856-1860). Do resultado da guerra, Eça diz:

Depois de entrar vitoriosamente em Pequim [...], roubado e queimado o "Palácio de Verão", [...] A Europa força a China a abrir na sua carta cinco portos ao comércio europeu, aos algodões, às ferragens, às ninharias ocidentais, e sobretudo ao ópio, ao imenso ópio, a seis, sete milhões de quilos de ópio por ano! (QUEIRÓS, 2002, p. 533-534) 
Mais uma vez surge a consciência crítica do escritor que enxerga no interesse meramente comercial o principal objetivo europeu por trás da guerra. Como consequência do combate, Eça destaca a ida de chineses à Europa para aprender sua tecnologia. A partir daí, o autor d'Os Maias faz uma análise inversa do que havia mostrado até o momento. Em outras palavras, até agora o intelectual português caracterizou como o Europeu mediano enxergava as nações asiáticas. Agora irá simular o pensamento chinês acerca do Europeu, fazendo "uma reflexão em mão dupla" (OLIVA, 2008, p. 76):

O Chinês tem pelo Europeu um horror, de instinto e de razão, fisiológico e raciocinado, que está muito bem caracterizado numa página dos Anais Populares do Império em que se conta a primeira aparição dos holandeses em Macau, e nas vizinhanças de Cantão. "Estes homens (diz essa amarga narração) pertencem a uma raça selvática que habita regiões escuras e húmidas, e que nunca teve a vantagem de se relacionar e aprender com a China. São criaturas avermelhadas, de olhos azulados e estúpidos, e imensos pés de mais de um côvado. Parecem lamentavelmente ignorantes. E como aspecto exterior nada se pode imaginar de mais exótico e repelente!" Aí está a impressão que os bons flamengos (que nos parecem tão sólidos, sãos e limpos tipos de homens) fizeram aos Chineses. E os portugueses que nos fins do século XV apareceram nas costas da China, e os ingleses e franceses que vieram depois no rasto das nossas caravelas, não foram mais simpáticos aos filhos do Céu. (QUEIRÓS, 2002, p. 534)

E, em seguida, traça como a civilização europeia aparenta ser incompreensível ao chinês, tendo como consequência o despertar de um sentimento patriótico e o repúdio ao estrangeiro. A visão do europeu como "diabo estrangeiro" e o sentimento patriótico chinês não são novos em Eça. Em quase todos os textos em que o autor de A Relíquia trata da China, esses pontos aparecem. Por exemplo, em um texto publicado no volume 2, número 2 da Revista de Portugal, datado de fevereiro de 1890 e com o título de "Notas do Mês", Eça, ao falar do ultimatum inglês, exprime as mesmas ideias:

Nem os nossos progressos industriais, nem a nossa inteligência e ciência, constituem influências bastante fortes para deschinesar o chinês. Pelo contrário! Quanto mais nos conhece - menos respeita uma civilização que se lhe afigura singularmente tumultuosa e estéril [...] As nossas classes operárias e rurais parecem-lhe atrozes: - e os 
nossos conflitos sociais de capital e trabalho, uma rude e estúpida manifestação de barbárie (QUEIRÓS, 1995, p. 60).

Até este momento do texto, através dos trechos e citações aqui apresentados, vemos constantemente uma tentativa de equiparação entre a cultura europeia e a cultura chinesa. Não apenas demonstra saber que a civilização chinesa é mais complexa do que se julga normalmente no velho continente, mas às põe em pé de igualdade em diversos momentos, como na comparação de Paris e Pequim ou na demonstração de que uma visão estereotipada do "outro" está presente tanto no pensamento europeu comum, quanto na imagem chinesa acerca dos europeus, conforme se pode ver claramente nestes últimos dois trechos destacados.

Assim, até aqui, mostra-se, de um modo geral, um ponto de vista bastante favorável à civilização chinesa. Entretanto, o texto não se encerra aí. Quando Eça deixa de traçar o estereótipo chinês para o europeu e vice-versa, e volta a tratar do conflito bélico entre a China e o Japão, o tom do discurso muda e, a partir deste ponto, se inicia o que, na nossa divisão proposta, é a segunda parte do texto. Eça já havia dito:

O motivo por que se estão batendo chineses e japoneses não é o que particularmente nos interessa. [...] $\mathrm{O}$ que ardentemente nos deve ocupar, a nós europeus e a vós americanos, são as consequências da guerra. [...] A China vitoriosa seria a China readormecida. A China vencida - é a Europa ameaçada" (QUEIRÓS, 2002, p. 530).

A derrota da China levaria a uma inevitável diáspora de seus habitantes a nações da Europa e da América. Eça não retrata mais a China letrada, mas agora começa a falar dos trabalhadores, dos chineses que emigram atrás de trabalho. Baseado principalmente em sua experiência vivida em Havana, mas também com o conhecimento da experiência da utilização de mão de obra chinesa em outras regiões do planeta como os Estados Unidos e a Austrália, o romancista português passa a caracterizar esses trabalhadores.

Conjeturando a vitória do exército japonês, Eça prenuncia:

Mas virá, todavia, o homem amarelo! Virá muito humildemente, muito pacificamente, em grandes paquetes, com a sua trouxa às 
costas. Virá, não para assolar, mas para trabalhar. E é essa a invasão perigosa para o nosso velho mundo, a invasão surda e formigueira do trabalhador chinês (QUEIRÓS, 2002, p. 541).

Como já havia feito em A Emigração como Força Civilizadora, Eça usa a experiência da Califórnia para exemplificar o que poderia se tornar a Europa.

A Califórnia mostra [...] o que poderá ser, no nosso populoso continente, uma ilimitada vinda de chineses. Foi em 1852 que chegaram a São Francisco da Califórnia os primeiros cem chineses [...] Dez anos depois eram cem mil. Seriam hoje um milhão, muitos milhões deles, se o estado da Califórnia não os tivesse repelido como uma praga. (QUEIRÓS, 2002, p. 541)

Caracteriza esses trabalhadores, que conheceu em Cuba:

O Chinês não tem necessidades: uma única cabaia de chita ou lã grossa lhe basta para uma existência: um pouco de arroz e dois goles de chá o alimentam. Onde o branco, comilão e vicioso, precisa de ganhar dois mil réis por dia, o Chinês está feliz com três tostões, e acumula. (QUEIRÓS, 2002, p. 542)

Aponta suas qualidades: "tem admiráveis qualidades de trabalhador pontualidade, atividade, docilidade, adaptação perfeita a todas as formas de serviços. São superiormente inteligentes e inacreditavelmente sofredores.” (QUEIRÓS, 2002, p 542). Assim como vimos em A Emigração como Força Civilizadora, essas qualidades apontadas, até com certo exagero, fazem parte de outro tipo de "idealização" do povo chinês: o chinês incansável, inesgotável. Assim como no relatório de 1874, essa caracterização poderia preconizar um elogio ao chinês ou à utilização de mão de obra chinesa em território estrangeiro, mas na verdade, o que Eça quer dizer é que todas essas qualidades, na verdade, se tornam um grande problema nas nações europeias. Eça destaca os problemas econômicos que um trabalhador assim causa: "Um imigrante com estas capacidades é terrível, sobretudo em países industriais, porque altera profundamente a balança dos salários" (QUEIRÓS, 2002, p. 543).

Ou seja, a saída de trabalhadores chineses causa um grande desequilíbrio econômico às nações que o recebem. Por causa desse problema, os chineses foram expulsos da Califórnia e proibidos na Austrália, de acordo com o romancista português. 
Destaca que, ao chinês, não há problemas de castigos físicos, mas a maneira de castigá-lo é o corte do "rabicho", símbolo de sua moralidade: "A sensibilidade nervosa do chinês é mínima. [...] Toda a sua sensibilidade é moral e, assim, na Havana, o castigo terrível e verdadeiramente doloroso que se impõe ao chinês é cortar-lhe o rabicho." (QUEIRÓS, 2002, p. 542). Parece-nos que a representação de uma punição moral ser o maior castigo que o chinês pode receber é bastante difundida na Europa oitocentista, pois representações semelhantes aparecem em Tribulations d'un Chinois en Chine, de Julio Verne, publicado em 1879, um ano antes de $O$ Mandarim de Eça.

Eça insiste na instabilidade econômica causada pelos orientais por mais alguns parágrafos até que profetiza o caos que o continente europeu se tornaria. Para concluir seu raciocínio, se dirige irônica e diretamente ao público brasileiro. Cito:

Vós, amigos, aí no Brasil, parece que os desejais, para vos plantar e vos colher o café. Sereis inundados, submergidos. Virão cem, virão logo cem mil. Daqui a dez anos em São Paulo e no Rio tereis vastos bairros chineses, com tabuletas sarapintadas de vermelho e negro, fios de lanternas de papel, covis empestados de ópio, toda a sorte de associações secretas, uma força imensa crescendo na sombra, e cabaias e rabichos, sem cessar fervilhando. Mas tereis cozinheiros chineses, engomadores chineses - e sabeis enfim o que é uma sopa superlativamente sublime e um peitilho lustroso e digno dos deuses. Todas as outras colónias, portuguesa, italiana, alemã, serão insensível e subtilmente empurradas para as suas pátrias de origem - e o Brasil todo, em vinte anos, será uma China. (QUEIRÓS, 2002, p. 545)

Neste trecho final, o autor português não fala mais dos problemas econômicos. Eça aponta, agora, um outro problema causado pelos imigrantes chineses: os problemas culturais. Ao prever "vastos bairros chineses" em São Paulo e no Rio de Janeiro e ao predizer "O Brasil todo, em vinte anos, será uma China”, parece-nos que Eça está destacando que o chinês nunca adentra o país para onde emigra, e na verdade, acaba formando uma colônia fechada. Eça vai mais longe, ao dizer que os imigrantes chineses expulsam imigrantes de outros países. Portanto, o que Eça parece querer dizer é que trazer trabalhadores chineses é transformar, aos poucos, seu país em uma segunda 
China. Eça parece não crer em um convívio harmônico entre os trabalhadores do Império do Meio e o país onde vive ${ }^{55}$.

O que vemos nesse trecho final de "Chineses e Japoneses", são argumentos semelhantes aos expostos em A Emigração como Força Civilizadora, escrito vinte anos antes. Eça parece reforçar o seu argumento de "a heterogenia de raças não comporta fusão" (QUEIRÓS, 2000a, vol. 3, p. 2082) e tem como principais álibis para sua defesa os problemas econômico e cultural decorrentes da inserção de trabalhadores chineses. Em outras palavras, do mesmo jeito que a desestabilidade econômica aparece como argumento desfavorável à chegada de trabalhadores do império asiático, o receio de uma invasão cultural também surge de maneira semelhante nos dois textos.

Este parece ser o verdadeiro motivo que leva Eça a escrever "Chineses e Japoneses". Com a abolição da escravatura no Brasil em 1888, foi largamente discutida a entrada de trabalhadores chineses no Brasil para suprir a mão de obra. Intelectuais e governantes discutiram calorosamente essa possibilidade ao longo da década de 90 do século $\mathrm{XIX}^{56}$. Logo, Eça usa a guerra sino-japonesa como pretexto para desenvolver seu raciocínio e emitir ao seu público brasileiro seu parecer sobre a questão da introdução de mão de obra chinesa em outros países, neste caso específico, o Brasil.

Ao olharmos de um modo geral o texto, podemos identificar três aspectos que Eça escreve como representantes do Império do Meio: 1) uma imagem positiva, presente no imaginário oitocentista europeu que mostra a China - ligada à classe letrada - enquanto uma civilização que pode ensinar aos europeus, mas ignorada e subjugada por estes; 2) o chinês nativista - que aparece sem distinção de classe; e 3) uma imagem negativa - representada pelos emigrantes - que mostra os chineses como causas de problemas econômicos e culturais nos países ocidentais. No entanto, essas questões não

\footnotetext{
${ }^{55}$ Em 1896, Eça escreverá um texto intitulado "A Propósito da Doutrina Monroe e do Nativismo" para o mesmo jornal carioca em que defenderá a mesma ideia. A análise deste texto se dará mais adiante.

${ }^{56}$ Cf. OLIVA, 2008.
} 
se encerram em identificar um olhar positivo ou negativo da China por parte de Eça. Acreditamos que a questão é mais complexa. Entendemos, através dessas caracterizações feitas, que o ponto central do texto, como também detectamos nas análises de A Emigração como Força Civilizadora e "A França e o Sião", está no aprendizado. E, sob esse ponto de vista, tanto a Europa quanto a China são criticadas. Se, por um lado, Eça critica os Europeus que não adentram a China e a julgam pela “populaça iletrada e grosseira que se emprega nos misteres inferiores de barqueiro, carregador, criado, moço de fretes, vendedores ambulantes, etc.” (QUEIRÓS, 2002, p. 531), por outro também repreende os chineses que emigram, mas se fecham em colônias, aceitam trabalhar em condições desumanas e, assim, causam problemas de ordem econômica e cultural nos países que os acolhem. A Europa e China são, no fundo, representadas de jeitos similares. A grande crítica de Eça parece se encerrar na falta de interesse mútuo, em que o chinês vai a Europa ou a outros lugares do mundo apenas atrás de trabalho e se tranca em suas colônias, enquanto o europeu vai à China mas, dela, só quer o dinheiro. Nem os chineses tentam aprender algo com a Europa, nem os europeus com a China. A crítica de Eça mais profunda parece, então, não ser somente à limitação da visão do europeu mediano. Tampouco é uma crítica só ao povo chinês, causa de problemas econômicos e atritos culturais. A crítica parece ser a ambas, Europa e China, ou seja, Ocidente e Oriente, que convivem, mas não interagem, não se interessam um pela outro e, portanto, nada aprendem. A partir dessa percepção, podemos compreender a condenação tanto à emigração asiática exposta no texto de imprensa quanto à politica capitalista do velho continente. Parece-nos que o que o escritor quer dizer é que, se for para conviver dessa maneira, é melhor aos chineses ficarem na China e os europeus restarem na Europa. 


\subsubsection{A PROPÓSITO DA DOUTRINA MONROE E DO NATIVISMO}

Publicado, assim como "Chineses e Japoneses", em cinco partes, entre os dias 30 de março e 5 de abril de 1896, “A Propósito da Doutrina Monroe e do Nativismo" tem como tema principal a política americana aplicada pelo presidente norte-americano James Monroe cuja frase que a resume é "A América para os americanos", uma política, teoricamente, contra a colonização europeia na América. Como consequência dessa política adotada no primeiro quartel do século XIX, Eça discute a noção de nativismo, ou seja, a política de favorecer habitantes nativos de uma nação em detrimento a estrangeiros e imigrantes.

O autor português critica a política americana que em um período de oitenta anos terá se tornado "uma estranha evolução [...] desde que saiu, tão gravemente formulada, dos lábios do presidente Monroe, até se tornar esse aforismo oco e malavisado que hoje todo o yankee (e a imitação dele todo homem da América) lança com tanta inconsideração e arrogância” (QUEIRÓS, 2002, p. 587-588). Diz ser a Doutrina Monroe "excelente dentro do momento histórico que a originou" (QUEIRÓS, 2002, p. 588) mas, que

esta declaração está rigorosamente limitada pela sua própria data, nada significa fora do momento histórico que a originou e só poderia ser desenterrada dos arquivos e reaplicada se as potencias da Europa se coligassem de novo para arvorar a bandeira apostólica e tentar na América o restabelecimento de sistemas obsoletos, que elas próprias já arremessam para o lixo do passado... (QUEIRÓS, 2002, p. 592)

Nestas primeiras páginas de seu artigo, Eça acabar por traçar, como já notamos ser costume nos seus textos para a Gazeta de Notícias, uma contextualização, principalmente, histórica para seus leitores, até fazer a ligação entre a atuação da Doutrina Monroe com o nativismo americano: "Essa singular fórmula [...] significa (se não interpreto mal o sentimento que inspirou a fórmula) que a América, sendo uma obra 
exclusivamente da raça americana, só pertence à raça americana, e só pela raça americana pode ser explorada e gozada" (QUEIRÓS, 2002, p. 593)

Inicia-se, então, uma crítica ao sentimento nativista americano, em que o autor lembra que a verdadeira "raça americana" era a raça dos povos originários e exterminados por ingleses, espanhóis, portugueses, franceses e holandeses, sendo que “na América, só vejo uma raça, que é a Europeia” (QUEIRÓS, 2002, p. 593). A defesa desse argumento se dará, através de muitos exemplos e explicações, ao longo do restante do artigo.

A China surge no texto em um dos exemplos dados por Eça para criticar o sentimento nativista americano. O Império do Meio aparece justamente como a contraposição da ideologia americana.

Eça declara: “"A América pertence exclusivamente aos europeus que nasceram na América'. E este o seu verídico sentido. E dele provém a doutrina ruidosa do nativismo" (QUEIRÓS, 2002, p. 594). Aponta a China como a criadora de tal doutrina:

Não há todavia nenhuma originalidade nesta doutrina do nativismo. Nem ela nasceu na América. Mais de dois mil anos certamente são passados desde que a China a concebeu e a praticou. O nativismo é, com efeito, um produto chinês, adoptado durante algum tempo pelo Japão, depois por ele abandonado como caduco e caturra, e agora posto, com grande alarido, em circulação pelos povos americanos. (QUEIRÓS, 2002, p. 594)

Eça cita como o criador dessa doutrina o imperador Huang-ti, um dos "Cinco Imperadores", reis lendários conhecidos pela inteligência (NEEDHAM, 1954, p. 87) e considerados os formadores das tradições chinesas. Huang-ti é denominado no Ocidente como "O Imperador Amarelo" e também é considerado como um dos pais da Medicina tradicional chinesa ${ }^{57}$. Essa imagem positiva canonizada pela história, não é corroborada para Eça, que traça o imperador chinês como:

\footnotetext{
${ }^{57}$ De acordo com a versão eletrônica do dicionário de ideogramas chineses Kanji-Gen (2003), a obra mais antiga de medicina chinesa se intitula Huangdi Neijing ("Princípios da medicina interna do Imperador
} 
Um bandido, de ilimitado orgulho, ignorante e falso, que alterou toda a constituição política da China, delapidou as finanças, inventou uma religião grotesca em que confusamente entravam a humanidade e três espíritos que habitam uma ilha, cometeu o sacrilégio de reformar o calendário, perseguiu os poetas e os eruditos e queimou todos os livros sagrados da China (QUEIRÓS, 2002, pág. 594-595).

Neste trecho podemos notar uma crítica ao despotismo oriental semelhante ao que aparece em “A França e o Sião". No artigo de 1893, Eça criticara o rei siamês que vivia em seu castelo e abandonava sua população "no usual desleixo e porcaria" (QUEIRÓS, 2002, p. 375). Aqui, o imperador chinês é representado como um tirado que alterou a tradição chinesa como lhe conveio. Assim, mais uma vez, o egoísmo e a tirania aparecem como característica dos déspotas orientais, que, no campo da política, salvo as suas especificidades, pouco se diferenciam dos políticos da Europa (e seu imperialismo e colonialismo), seja no passado, com Huang-Ti, seja no presente, com o rei Chulalongkorn do Sião.

A seguir, usa essa filosofia imposta como a justificativa para a reclusão do Império do Meio em relação ao Ocidente e a origem de repulsão que os chineses têm dos povos europeus, segundo Eça. Cito:

Desde que o escandaloso Huang-Ti e os seus mandarins (entre os quais dominava um certo Liseu, meio letrado e meio feiticeiro) conceberam a ideia de que o uso da China devia ser vedado a todos os que não fossem nativos - fecharam a China, fecharam materialmente toda a China do lado da terra com a Grande Muralha, e do lado do mar, nas embocaduras dos rios, com fortes correntes de bronze e hediondos dragões de madeira pintada. Depois, assim enclausurados na sua China como uma imensa e silenciosa cidadela, o mundo nunca mais soube deles e quase perdeu a noção da sua existência entre as gentes. De resto, durante os seguintes séculos, se, apesar de todas essas correntes e muralhas, algum estranho penetrava na China por motivos espirituais ou temporais, logo uma populaça nativista corria sobre ele com bambus e cutelos, e do intruso abominável só restava

Amarelo", de acordo com a edição brasileira da editora Ícone - 2013), de data e autores desconhecidos. Assim, este livro é considerado a "bíblia da medicina chinesa". Embora este texto não tenha sido escrito pelo "Imperador Amarelo" (A edição brasileira de Huangdi Neijing credita a autoria deste livro a Bing Wang, que teria vivido na Dinastia Tang que vai de 618 a 907 da era cristã), pelo título denota-se que se atribui a ele o conteúdo presente na obra. J. A. G. Roberts credita o desenvolvimento da medicina tradicional chinesa a um reinado anterior ao de Huang-ti. Porém, confere a este rei o desenvolvimento da escrita, cerâmica e do calendário chinês (1999, p. 3). 
em breve uma massa roída e retalhada em cima de um charco de sangue. (QUEIRÓS, 2002, p. 595)

A cena descrita nas últimas linhas da citação, "uma populaça nativista corria sobre ele com bambus e cutelos, e do intruso abominável só restava em breve uma massa roída e retalhada em cima de um charco de sangue", pode-se usar como o resumo do capítulo VI de $O$ Mandarim (1880), quando Teodoro chega a aldeia de Tien-Hó e na mesma noite é expulso e quase morto pelos habitantes da pequena vila. Portanto, vemos que a representação da China como lugar intransponível não é nova para o escritor português. Tanto em $O$ Mandarim, como veremos no capítulo seguinte, quanto em "Chineses e Japoneses", conforme analisamos, Eça já havia apontado como único caminho possível para se adentrar a China, seria se tornar um chinês. No texto de 1894 conta sobre:

um secretário da legação inglesa, que falava com perfeição o chinês, não só o idioma popular, mas a linguagem mandarina e clássica, e que deixara crescer um enorme rabicho. Este homem absolutamente achinesado vestia a sua cabaia de seda, soltava o rabicho, tomava um leque e ia passar algumas horas amáveis com as famílias nobres de Pequim (QUEIRÓS, 2002, p. 532).

Então, o único exemplo de homem que adentrou realmente à China, para Eça, foi um inglês que se "achinesou”. Ainda, só convivia com as classes nobres. A China do restante da população ainda permanece, para nosso escritor, como um lugar impenetrável.

Apesar de, em seu texto, não ser simpático a nenhum tipo de nativismo, Eça demonstra compreender esse sentimento na população chinesa, afinal tudo que há no país asiático é fruto do trabalho de seu povo. Assim, encontra justificativa deste sentimento existir na China.

Esse curioso fenómeno do nativismo chinês, muito facilmente se lhe encontra justificação e até grandeza. Os Chineses não são somente os primitivos senhores da China, mas são os primitivos e únicos criadores da sua civilização, que é só deles, bem original e bem própria, sem mistura de ideia ou forma alheia. Foram eles, só eles, que 
tiraram da sua razão, do seu sentimento e da sua fantasia tudo o que temporalmente e espiritualmente constitui a China, a sua organização política, a sua religião, a sua moral, o seu direito, a sua agricultura, a sua indústria, a sua literatura, a sua arte, os seus cerimoniais, as suas armas, os seus trajes... Toda a China é absolutamente e unicamente de invenção chinesa (QUEIRÓS, 2002, p. 595-596).

Como em quase todas as vezes em que desenvolve um raciocínio acerca da China, Eça de Queirós volta a tratar da questão da emigração chinesa, que, relembramos, foi vista enquanto trabalhava em Cuba como cônsul português. Dessa vez, Eça não trabalha mais as causas da emigração, mas fala do emigrante como exemplo da "homogeneidade" da civilização chinesa, uma vez que sempre que vai a outro país forma uma comunidade fechada, igualmente intransponível. Ou, nas palavras de Eça, "uma pequena China" (QUEIRÓS, 2002, p. 596) Cito:

E tão intensamente homogénea é esta civilização que qualquer ideia ou costume que chegue de fora e consiga cair nesse compacto fundo de costumes e de ideias não se funde, não penetra na circulação da vida ambiente: fica enquistada, no lugar onde pousou, como um caroço estéril, e em breve se mirra e se desfaz. E pelo mesmo motivo, para onde quer que emigre (agora que emigra) o Chinês instala uma pequena China, onde vive de uma existência só chinesa, tendo já ao lado um esquife chinês para que, apenas morto, o reconduzam dentro dele à grande China. (QUEIRÓS, 2002, p. 596)

Destaca ainda o afeto do chinês pela China, como fruto do sentimento nativista: “para o Chinês, como todos os moralistas e poetas afirmam, não há ventura mais certa na Terra do que nascer e ser chinês” (QUEIRÓS, 2002, p. 596).

Mais uma vez, como em “Chineses e Japoneses”, Eça faz uma análise inversa para criticar a política europeia e, assim, justificar o sentimento nativista chinês. Simula a vinda de chineses à Europa, não para trabalhar, mas para impor seu modo de vida $\mathrm{e}$ sua cultura. Reflete:

O sentimento dos Chineses realmente equivale ao que seria o nosso, na Europa, se os Amarelos viessem, com missionários, com empreiteiros, com letrados, com artífices, instar, fazer propaganda para que nós usássemos rabicho, habitássemos casas de bambu e papel e viajássemos em liteiras de machos, só lêssemos o livro dos Deveres Filiais e queimássemos cada manhã um rolo de cera perfumada em louvor de Confúcio. Como a Europa então soltaria o grito unânime e 
feroz de supremo nativismo: "Fora os Chineses!" (QUEIRÓS, 2002, p. 597)

E, novamente, recorda-se da situação chinesa na Califórnia, ironizando a máxima da Doutrina Monroe e criticando a imagem de uma colônia para os americanos:

\begin{abstract}
A Europa é para os Europeus! De resto, esse grito rancoroso já o brama sem cessar a Califórnia, contra os pobres celestiais que vêm trabalhar a S. Francisco, e sem que eles intrusivamente missionem as suas ideias ou os seus costumes (como nós fazemos na China), e só porque no meio da cidade branca, de raça saxónica irisada de espanhola, faz uma mancha irritante aquela colónia amarela, de cabaia e de rabicho, que cheira adocicadamente a ópio (QUEIRÓS, 2002, p.597).
\end{abstract}

Toda essa caracterização, como se pode perceber, é para justificar o sentimento nativista pelos chineses, sempre em contraposição ao sentimento nativista americano, principal objeto de crítica neste texto de Eça. O texto ainda segue por mais algumas páginas, quando Eça simula um movimento nativista no Brasil e desenvolve uma análise sobre a América espanhola. Nas poucas vezes, depois, em que a China é citada nada de diferente do já exposto é apresentado, portanto, optamos por deter a análise neste ponto do texto.

A China, neste texto, aparece de forma semelhante ao Extremo Oriente de As Farpas. Isto é, não é o tema principal do artigo, mas a caracterização dela se torna fundamental para os objetivos do escritor, uma vez que esta atua como contraponto do que está sendo criticado.

Este texto dialoga diretamente com o texto "Chineses e Japoneses", previamente analisado. Alguns pontos em comum com a caracterização da China são encontrados: China como um lugar fechado, seja para o Europeu que foi à China, mas só a conhece pela fachada de suas lojas, seja nos locais que usam de mão de obra chinesa para trabalhar. Ainda apresenta o chinês enquanto ufanista e também faz uma rápida crítica à política "civilizadora" europeia, quando destaca entre parênteses que os europeus vão 
missionar ideias e costumes na China. Além disso, poderíamos fazer um paralelo entre este texto e A Emigração como Força Civilizadora. No relatório apresentado em 1874, Eça diz que "Uma colônia assim, suja, denigre uma cidade" (QUEIRÓS, 2000a, vol. 3, p. 2081). Agora, vinte e dois anos depois, trabalha ironicamente com essa ideia, quando diz da "mancha irritante" que é uma colônia chinesa. Por tudo que já foi exposto neste e em outros textos, nos parece clara a mudança de visão do autor português adquirida com o passar desses anos e com sua formação intelectual. Neste texto, escrito já nos últimos anos de sua vida, ele ironiza o pensamento que um dia fora seu também.

Para concluir a análise, vemos que a China representada neste artigo não apresenta explicitamente novas ideias. Apesar de não detectarmos nenhuma crítica ao aprendizado, conforme vimos em outros textos, as ideias de "A Propósito da Doutrina Monroe e do Nativismo" reforçam outras questões já percebidas em outros artigos, principalmente "Chineses e Japoneses". Portanto, essas representações da China, e, porque não, do Extremo Oriente, parecem estar claramente definidas na cabeça de Eça, ao longo da década de 90 do século XIX.

\subsection{O EXTREMO-ORIENTE NA REVISTA MODERNA - "FRANÇA E SIÃO"}

A Revista Moderna - inicialmente quinzenal, posteriormente mensal - foi publicada em Paris e durou aproximadamente dois anos: o primeiro número saiu em 05 de maio de 1897 e o último em 30 de abril de 1899. A direção do periódico era do brasileiro Martinho Carlos de Arruda Botelho e Eça de Queirós foi um importante colaborador.

Assim como em A Gazeta de Notícias, a publicação de Eça neste periódico compreende textos ficcionais e jornalísticos. De sua ficção, de acordo com Campos 
Matos (1988, p.566), foram publicados parte de A Ilustre Casa de Ramires $^{58}$; os contos A Perfeição (1897), José Matias (1897) e o Suave Milagre ${ }^{59}$ (1898); e a Carta a Bento, posteriormente adaptada à carta XV de A Correspondência de Fradique Mendes. Já sua produção não-ficcional é composta de nove artigos. O texto de apresentação da revista (intitulado "A revista") foi de autoria de Eça, e foi publicado em 15 de maio de 1897. Os outros artigos foram: "Na praia" (20 de agosto de 1897), "No mesmo hotel" (05 de setembro de 1897), "Antigas visitas" (20 de setembro de 1897); "França e Sião" (05 de outubro de 1897), "Encíclica Poética" (20 de outubro de 1897), "O marquesinho de Blandford” (05 de novembro de 1897), “A rainha" (15 de janeiro de 1898) e "Eduardo Prado" (julho de 1898). Estes artigos foram todos postumamente integrados à obra Notas Contemporâneas (1909).

Da relação de Eça de Queirós com a Revista Moderna destaca-se ainda um número inteiro dedicado ao autor de Os Maias. Foi o número 10, de 20 de novembro de 1897. Este número teve a colaboração de alguns de seus "amigos e admiradores, portugueses e brasileiros" (BERRINI, 2000, p. 1552), como Eduardo Prado, Maria Amélia Vaz de Carvalho, conde de Arnoso, Batalha Reis, conde de Ficalho, conde de Sabugosa, Mariano Pina, Luís de Magalhães, Domício da Gama e Abel Botelho (CAMPOS MATOS, 1988, p. 566).

Centraremos nossa atenção no artigo publicado no número 07 da revista, em 05 de outubro de 1897, intitulado "França e Sião". Embora com título muito próximo, este texto tem diferenças significativas em relação a "A França e o Sião", publicado na

\footnotetext{
${ }^{58}$ Beatriz Berrini, em sua Obras Completas de Eça de Queiróz, citando Guerra da Cal, recorda que a publicação corresponde a "uma terceira versão [...] de A Ilustre Casa de Ramires, incompleta" (2000, vol. 3 , p. 1552). Posteriormente, trata esta versão como a "primeira versão d'A Ilustre Casa de Ramires" (2000, p. 1553).

${ }^{59}$ Berrini lembra-nos que esta versão de $O$ Suave Milagre é uma nova reelaboração do conto (BERRINI, 2000, p. 1552). Versões anteriores já tinham sido publicadas, em 1885, sob o título de Outro Amável Milagre e, em 1897, com o título Um Milagre (CAMPOS MATOS, 1988, p. 592).
} 
Gazeta de Notícias em 1893. A crítica presente, no entanto, é bastante similar. Vejamos, então, como ela aparece no texto.

Assim como em textos da Gazeta de Notícias, como "Chineses e Japoneses", Eça inicia seu texto utilizando um fato dos dias correntes para tratar de outra questão, revelada no decorrer da leitura. Aqui, o ponto de partida da redação deste curto artigo é a visita do rei Chulalongkorn, o mesmo ironizado no texto de 1893, à França. O encontro diplomático de 1897, descrito como "semipasmado, semienfastiado" (QUEIRÓS, 2005, p. 75), serve como motivação para Eça voltar mais de duzentos anos no tempo e narrar, de maneira muito bem humorada, o primeiro contato entre os povos de França e Sião em 1685. Assim, nesse texto, ao contrário dos anteriores, Eça não fala de sua contemporaneidade.

O autor inicia narrando a chegada de dois siameses que aportaram em Marselha para saber notícias sobre uma embaixada enviada pelo rei de Sião:

[...] em Marselha e depois em Paris apareceram dois siameses, de simarra e mitra, perguntando, sem ansiedade nem ruído, se alguém avistara uma embaixada mandada, havia longos meses, com precisos presentes, por El-Rei de Sião a El-Rei de França... Uma embaixada? Não! Ninguém em Marselha, nem em Versalhes, vira essa embaixada magnífica... Os siameses suspiravam de leve. Bem! Então é que o mar amargo a tragara como traga tudo o que vem do lustroso Oriente, até cada tarde o Sol! E os dois siameses, sem mais pesar ou embaraço, começara a contar, desde Marselha até Paris, o imenso entusiasmo que El-Rei de Sião sentia pelo Cristianismo, e sobretudo por aquele grande rei de França, que lhe aparecia como o mais sapiente e o mais forte da Cristandade... (QUEIRÓS, 2005, p. 75).

É interessante perceber que já no primeiro parágrafo do texto, Eça, como em seus outros textos jornalísticos, apresenta ironicamente a visão do oriental passivo. Aqui, se destaca a caracterização siamesa como "sem ansiedade nem ruído", "sem pesar nem embaraço", ou a reação perante a perda da embaixada perdida como um suspiro “de leve". Assim, como em outros textos, o autor de Os Maias brinca com essa faceta positivamente "idealizada" do pensamento europeu. Esta visão também aparece não 
mais na caracterização das pessoas, mas desta região ao se referir ao Oriente como "lustroso", fazendo um jogo entre a luz das riquezas que a Europa retirava de suas colônias orientais com a luz do sol.

Com a chegada dos siameses a Versalhes, nosso autor caracteriza o Rei Luís XIV da França:

O Grande Rei entrara então na sua desagradável velhice. Perdera todos os dentes - e já os beiços moles se encovavam, repuxados pelas gengivas nuas, causando desgosto a Vênus. A larga face conservava majestade, mas rígida, com as rugas como entalhadas em madeira. E o olhar, outrora brilhante, era agora apenas agudo e triste. Além disso, desde que, na sua evolução através dos pecados mortais, ele deslizara da luxúria para a gula, sofria de indigestões, cólicas, acidezes, gases retumbantes, que o tornavam taciturno e amargo. Quantas cruéis perseguições dos protestantes provieram do intestino de El-Rei! A seca e meticulosa Madame de Maintenon, com que Luís casara, era tanto enfermeira como esposa e portanto duplamente omnipotente sobre um rei beato e priápico, que amava a carne, temia a morte, e não queria amar nem morrer fora de braços não autorizados pela Igreja. (QUEIRÓS, 2005, p. 76).

A burlesca descrição do decadente rei francês não difere muito da descrição do então rei do Sião. Embora esta só apareça nos parágrafos finais do texto, já apresentaremos o trecho para que possamos ver a similaridade: “[...] El-Rei surgiu. Era um velhito magrinho, enrugadinho, todo rapado, com uma enorme verruga no queixo, eriçada de dois pelos longos e mais rijos que piaçaba" (QUEIRÓS, 2005, p. 81).

A decadência de ambos os reis faz com que possamos ler que, mais uma vez no jornalismo queirosiano, Oriente e Ocidente são postos em paridade. A ausência de altivez nas figuras reais e a ironia voltada a ambos faz com que não haja qualquer propensão em exaltar o Ocidente em relação ao Oriente ou o Oriente em relação ao Ocidente. Tal imagem dialoga com os textos jornalísticos da Gazeta de Notícias, principalmente com "A França e o Sião", em que essas duas nações também são equiparadas. 
Eça prossegue seu texto contando que, devido a este suposto interesse do rei de

Sião à Cristandade, o rei Luís XIV decide enviar uma embaixada à capital siamesa.

Nosso autor, então, fala-nos sobre os membros que compunham a comitiva:

Para uma missão toda religiosa, toda espiritual, que tendia converter um rei idólatra e com ele todo um reino, foi escolhido um velho capitão-de-fragata, o cavalheiro de Chaumont. Com razão o Grande seminário das Missões, arrepiado, exalou a sua inquietação. Certamente, Mr. Chaumont possuía crença muito fortes, uma devoção muito edificante... Mas a ciência teológica? Poderia ele discorrer proveitosamente sobre a Religião e, sobretudo, desfazer as objecções que o rei idólatra, sob a inspiração do Demónio ameaçado na sua posse, não deixaria de apresentar com capciosa abundância? Por isso o Seminário propunha que se completasse a embaixada com um coadjutor, teólogo forte, bom, dialético, e dotado de insinuância cortesã indispensável para a conversão de um rei do Oriente. [...] E assim foi adjunto ao capitão-de-fragata de Chaumont, como coadjutor, o abade de Choisy [...]. Além deste abade, acompanhavam a embaixada seis padres jesuítas - mas esses como matemáticos, geógrafos, botânicos, sem encargo especial da alma do rei, e só destinados a restabelecer o mapa e a estudar os recursos dum reino onde a Companhia esperava em breve ter colégios e plantações. Outro membro eminente da embaixada era o conde de Forbin, oficial da marinha, que, tendo escaramuçado com os piratas de Argel, passava na corte por possuir "uma considerável experiência do Oriente", e [...] com os deveres de língua, drogman e mestre de cerimônias. E enfim havia uma comitiva de fidalgos menores e filhos segundos que partiam, não por curiosidade ou apetite heroico de aventuras, mas, como diz nas sua memórias o próprio Forbin, "para agradar e fazer sua corte ao rei!" (QUEIRÓS, 2005, p. 77-78, grifos do autor).

Neste trecho a visão europeia do Oriente é desvendada. A escolha do conde de

Forbin é feita por ele ter "uma considerável experiência do Oriente". No entanto, no texto é dito que este conhecimento do Oriente vem do confronto com piratas de Argel, Argélia, ou seja, uma região do norte da África. Deste modo, aparece claro que regiões tão distantes e culturas tão diferentes como a argeliana e a siamesa eram vistas como algo único, tudo como "Oriente”. Assim, mais uma vez, as palavras de Eça dialogam com a teoria saidiana, proferida no século XX.

No mesmo trecho também se percebe o objetivo francês em ir ao Sião: a catequização e o comércio. Obviamente, estes foram os principais objetivos das navegações europeias desde os séculos XV e XVI, mas ao evidenciar que seis padres 
jesuítas iam para "estudar os recursos" do reino, vê-se claramente que se considerava no século XVII, como no século XIX, conforme notamos em outros textos - os povos do Oriente como inferiores. Deste ponto de vista fica claro que, já nessa época, acreditava- se que "o animal inconsciente foi posto sobre a Terra para nutrir o animal pensante - e por isso [...] os países orientais são feitos para enriquecer os países ocidentais" (QUEIRÓS, 2002, p. 368-369), conforme Eça ironizara no texto de 1893.

Com a partida da embaixada francesa ao reino do Sião, o autor de Os Maias passa a enfocar este reino asiático. Aí é apresentada a figura de Constâncio, um grego que através de sua astúcia conseguira o cargo de "barcalon", isto é, de acordo com nosso autor, primeiro-ministro do reino.

O rei do Sião, como Luís XIV, envelhecera - e o poder resvalara para um certo aventureiro grego da ilha de Samos, chamado Constâncio, que desembarcara uma manhã nas costa de Sião, sem sapatos nem gibão, e começara logo a exercer as suas divinas prendas de grego. Dentro de poucos dias, era secretário do primeiro-ministro, ou, como se dizia em siamês nesse tempo, do Barcalon. E meses depois, era ele o Barcalon, pois que o rei, fascinado com a graça a astúcia, a eloquência, a destreza, as invenções daquele divino grego, se desembaraçara do outro Barcalon, bronco e ronceiro - e, da melhor maneira, da bela maneira definitiva que se usa no Oriente, e que impede as intrigas importunas do ministro despedido, separando do corpo a cabeça que as urdiria. (QUEIRÓS, 2005, p. 78).

A maneira autoritária e despótica com que Eça trata do modo como o antigo primeiro-ministro é demitido - e assassinado - configura uma crítica semelhante a presente no texto "A França e o Sião" da Gazeta de Notícias. Lá, ele criticara o “ilimitado poder" (QUEIRÓS, 2002, p. 374) que estraga o rei Chulalongkorn. Aqui, novamente, esta crítica está presente através da ironia do método de demissão aplicado pelo rei.

Adiante, Eça revela que o interesse pela fé cristã do rei de Sião, na verdade, é um plano desenvolvido pelo "Barcalon" Constâncio:

Erguido Barcalon, o admirável Constâncio [...] teve uma ideia ocidental - a de apoiar o seu poder na amizade e na força dum rei da 
Europa. Mas qual? Dos povos então fortes no mar, o Inglês e o Holandês só sustentariam se ele, como Barcalon todo-poderoso, lhes garantisse grossos lucros mercantes no Sião - e o Sião, apesar da reluzente lista que Fernão Mendes Pinto deixou das suas riquezas, é na realidade país escasso. Aos Portugueses não desejava o astuto Constâncio dar entrada larga no Sião. Ah! os Portugueses (como ele depois confessava) eram feras do mar! E bem poderiam, desapossados da Índia, buscar desforra no Sião, que eles sempre lamentavam de não terem, por seus pecados, conquistado em lugar da fatal Índia! Restavam pois os Franceses, que o bom Constâncio considerava "mais fáceis de enganar", sobretudo acariciando sua leviana e confiada vaidade. E o grego [...] engodara o grande rei de França com a premissa daquela conversão à complicada e trabalhosa fé cristã, conversão inverossímil da parte dum soberano velho, que, em matéria espiritual, se achava perfeitamente ditoso dentro da fácil e repousada fé budista. (QUEIRÓS, 2005, p. 78-79).

É curioso notar que, aqui, o texto de Eça, ao afirmar que "apesar da reluzente lista que Fernão Mendes Pinto deixou das suas riquezas, é na realidade país escasso", contrasta com outra imagem que transmitira em seu texto de 1893, ao dizer: "Sião é um reino do Extremo Oriente, muito rico e, portanto, muito apetecível” (QUEIRÓS, 2002, p. 368).

Oriente e Ocidente são novamente equiparados quando ambos os reis são enganados por Constâncio. Afinal, com sua astúcia, o grego em pouco tempo adquirira grande poder dentro da corte siamesa. Do mesmo modo, o rei francês, escolhido por Constâncio por ser "mais fácil de enganar", é vítima de sua esperteza. Assim, seja na credulidade em Constâncio, seja na descrição da figura decadente de ambos os reis, seja nas ideias, França e Sião são tratados da mesma maneira. A mesma ironia abrangerá esses dois reinos, pois, depreendemos, para Eça, Ocidente e Oriente, em sua essência, se equivalem.

O texto prossegue com a narração da viagem da embaixada francesa ao Sião, até sua chegada ao "pardacento banco de lodo, que era a barra do Sião" (QUEIRÓS, 2005, p. 79). Então, é descrito o primeiro contato entre a comitiva francesa e a população “selvagem" siamesa: 
O conde de Forbin, começando os seus deveres de mestre de cerimônias, saltou num bote para cumprimentar o governador da barra, levando u dos submissionários na esperança de atacar logo alguma das almas rebeldes. Mas aí começou para o brilhante mestre de cerimônias um amargo e humilhante desapontamento. De recamado uniforme, coberto de plumas, com talabarte de seda e matiz viera ele, esperando visitar um personagem no seu palácio. Encontrou uma cabana de bambus, coberta de folhas de palmeira, e dentro, num esguio espaço "sem poltronas, sem tapetes, sem lustres" três indivíduos "sem sapatos, sem meias, sem cabeleira, sem chapéu, com um vil paninho à cinta para lhes velar a nudez indecente!". Todavia, apesar do escândalo o major da embaixada, à porta, rojando na lama as fofas plumas do seu chapéu, numa cortesia funda à moda grande de Versalhes, perguntou onde se encontrava o governador da barra. Um dos sujeitos seminus e encruzados sorriu e murmurou com doce polidez: - Sou eu! (QUEIRÓS, 2005, p. 79-80).

O choque cultural do encontro entre a comitiva francesa e a população do Sião evidencia, novamente, o olhar europeu em relação ao Oriente, vendo na falta de trajes ou na ausência de qualquer espécie de sofisticação do ponto de vista europeu a ratificação da imagem dos siameses enquanto "selvagens", "inferiores", ou, como ironizara em 1893, "bichos tão feios" (QUEIRÓS, 2002, p. 372). O que Eça, em “A França e o Sião" sentenciara como "a verdadeira doutrina do século [XIX]” (QUEIRÓS, 2002, p. 372), parece também valer para as relações Ocidente-Oriente do século XVII.

Para estabelecer as relações entre o reino de Sião e o reino de França, diz Eça, é necessária a entrega de uma carta de Luís XIV ao rei do Sião. Aqui, mais uma vez, o autor de $O$ Mandarim ironiza o choque cultural entre os dois povos.

Outro mês se arrastou em decidir a questão gravíssima, quase terrível da entrega da carta de Luís XIV a El-Rei de Sião. Essa carta devia passar diretamente da mão do embaixador para a mão do rei [...]. Mas aí surgia a dificuldade inextricável! El-Rei de Sião não recebia os embaixadores num trono, com degraus, e acessível; recebia numa vasta sala nua, com um muito alto postigo aberto no topo, junto ao teto, onde o rei desfranzida uma cortina, aparecia, saudava e desaparecia. Como se poderiam assim encontrar as duas nobres mãos? Os franceses sugeriam a construção duma escada, tapetada de brocados, por onde o embaixador solenemente trepasse ao Real Postigo... Horror intenso dos siameses! Um rei assim tão aproximado seria para sempre um rei poluído! E por seu turno, com uma imaginação toda oriental, propuseram que o embaixador levasse na mão uma vara de outro, de três metros, terminada numa taça também de ouro, onde pousaria a carta, que El-Rei de Sião colheria levemente e afavelmente debruçado do postigo. (QUEIRÓS, 2005, p. 80-81). 
Esta cerimônia de entrega da carta é o momento em que aparece a descrição do rei do Sião, que apresentamos anteriormente. Neste trecho do artigo, também, é apresentado mais um momento em que o autor destaca o desprezo francês pelo reino asiático. Cito:

Imediatamente o embaixador avançou, com a vara de outro na mão... Mas, ou porque a vara fosse realmente curta, ou porque o embaixador, por altivez francesa, para afirmar bem a grandeza do rei da França, não a erguesse suficientemente, El-Rei do Sião, para colher a carta, tanto se debruçou que se despenharia, se mãos invisíveis e decerto trémulas o não tivessem apanhado, com ânsia, pelas abas do seu gibão cor de fogo! Toda a corte estremeceu de terror sagrado. E todos os fidalgos da embaixada romperam a rir desabadamente, certos da orgulhosa malícia do embaixador, e felizes de testemunharem enfim, depois de tão fastidiosos meses, naquelas terras selvagens, alguma coisa (como dizem as memórias) "bem espirituosa, bem brilhante e bem francesa” (QUEIRÓS, 2005, p. 81).

Adiante, já nos últimos parágrafos do texto, Eça conta que, em retribuição, o reino asiático enviara uma embaixada a Versalhes para selar “a aliança de Sião (isto é, de Constâncio) e da França" (QUEIRÓS, 2005, p. 82). A chegada da comitiva siamesa corrobora a incompreensão europeia:

E essa embaixada veio, tão autêntica, tão siamesa, que Versalhes e mesmo Paris, não compreendendo que realmente existisse um povo com tais trajes e tais modos e tal língua, sinceramente acreditaram que a embaixada era uma luxuosa mascarada, engenhada por madame de Maintenon para divertir o tédio de Luís XIV e lhe acariciar o voraz orgulho. (QUEIRÓS, 2005, p. 82)

Após o retorno da embaixada siamesa ao seu reino, o autor de Os Maias nos revela que o "embaixador siamês, voltando ao Sião com o prestígio que dão as viagens e a frequentação das cortes estrangeiras, criou um partido, tramou uma revolta, depôs o velho rei da verruga peluda, e prendeu o astuto Constâncio, que para maior segurança, mandou serrar entre duas tábuas!” (QUEIRÓS, 2005, p. 82).

Neste trecho, uma imagem anteriormente percebida neste mesmo texto se apresenta: o despotismo presente no reino oriental, ao relatar o fim de Constâncio após a 
revolta feita pelo embaixador siamês. Também, neste parágrafo final, mais uma vez, Oriente e Ocidente são postos em paridade. Afinal, a atitude do embaixador do Sião não deixa de ser próxima a que Constâncio tivera quando chegou ao Sião ou quando enganou o rei francês para apoiar seu poder em um rei europeu. Assim, Eça parece não analisar tendenciosamente, optando pela Europa ou pela Ásia. Afinal, ironiza ambos: Ocidente e Oriente.

Deste modo, Eça encerra seu texto falando que, após este episódio e com a morte de Luís XIV, "França e Sião mutuamente se esqueceram durante dois longos séculos” (QUEIRÓS, 2005, p. 82).

Visto de um modo geral, aparentemente, este texto não apresenta imagens novas da relação Ocidente-Oriente. Do ponto de vista cronológico, este texto reafirma a maior parte das imagens que depreendemos dos textos da Gazeta de Notícias. Entretanto, se visto isoladamente, é um texto em que se pode perceber de maneira bastante clara como Eça de Queirós representou a relação Ocidente-Oriente em seus textos jornalísticos da década de 90, sua última década de vida.

Antes de passarmos à conclusão deste capítulo, gostaríamos de destacar o que pode ser a grande contribuição deste texto ao conjunto jornalístico queirosiano que versa sobre o Extremo Oriente: o artigo "França e Sião" narra o contato entre os povos ocorridos no século XVII. Entretanto, como pudemos ver ao longo deste estudo, as ironias e as críticas presentes neste texto são muito próximas das feitas em "A França e o Sião", de 1893. Desta maneira, podemos ler que, para Eça, esta relação conturbada não é fruto da revolução industrial e do modo de vida de sua contemporaneidade. Nosso autor mostra que a relação Ocidente-Oriente truncada, como se faz presente no século XIX, já se apresenta nos primeiros contatos no século XVII. Mostra como toda esta questão pouco evoluiu em dois séculos: o despotismo oriental ironizado é o mesmo; a 
falta de interesse é similar - vale lembrar que o envio dos siameses à França não foi idealizada pelo rei do Sião, mas por Constâncio, em busca de poder -; a visão europeia como civilização superior é idêntica. Assim, o Sião do passado é similar ao Sião do presente, assim como a França seiscentista pouco difere da França dos Oitocentos.

Com isto exposto, podemos passar à conclusão deste capítulo de nosso trabalho.

\subsection{CONCLUSÃO PARCIAL}

Como pudemos perceber ao longo dos diversos textos analisados, a caracterização do Extremo Oriente nos textos não ficcionais de Eça de Queirós acompanha seu desenvolvimento intelectual. Obviamente, ele trabalha de diversas maneiras essas representações, dependendo do objetivo e do enfoque dado a cada texto. No entanto, pudemos depreender inúmeras imagens que direta ou indiretamente permeiam o imaginário do romancista português.

Nos primeiros textos, da década de 70 , vemos uma forte preocupação com a situação portuguesa, o que faz com que o Extremo Oriente seja representado apenas pelas colônias de Goa e Macau ${ }^{60}$. Como vimos, quando as colônias asiáticas aparecem, são tratadas de maneira reduzida, como um estorvo ao desenvolvimento da sociedade portuguesa. Por isso, sempre é defendida a ideia da venda das colônias. Logo, abundam adjetivos redutores como "insignificante", "fracos" e "ignorantes". A cultura oriental é classificada como "velha", o que faz com que ela tenha seu lugar no passado, mas não no futuro.

Devido à natureza do texto, em A Emigração como Força Civilizadora, o Extremo Oriente é desenhado de maneira mais direta. Ou melhor, os trabalhadores

\footnotetext{
${ }^{60}$ A viagem de 1869 ao Oriente Próximo fará com que esta região ganhe outras cores na pena do autor neste momento inicial de sua carreira literária.
} 
chineses e suas colônias nos Estados Unidos, Austrália e, principalmente, Cuba são assim trabalhados. De acordo com os críticos citados, a caracterização desses trabalhadores se dá de forma "idealizada", conforme algumas imagens que povoavam o imaginário europeu do século XIX. Essas "idealizações" ilustram alguns aspectos que podem ser considerados positivos, uma vez que estes são classificados como trabalhadores "superiores" ao europeu. No entanto, Eça logo desmonta esta construção destacando os problemas que os operários de tais características causam. Usando-se de argumentos que podemos considerar eurocêntricos e etnocêntricos, Eça advoga contra a utilização de mão de obra asiática em colônias europeias. Como Elza Miné (1986) destaca, a influência do pensamento de Taine se dá fortemente nos argumentos apresentados pelo autor.

Já nos quatro textos escritos ao longo da década de 90 que analisamos, notamos uma mudança de postura. O Extremo Oriente, ali, aparece basicamente representado por dois povos: os chineses e os siameses. Japão e Coreia são também trabalhados em menor grau, mas refletem as mesmas imagens das duas regiões anteriormente citadas. Carlos Reis, em sua Introdução à edição de $O$ Mandarim, destaca que as crônicas jornalísticas queirosianas desta década revelam "em sintonia fradiquista ${ }^{61}$, um tempo de cepticismo relativamente à chamada civilização ocidental” (REIS, 2003, p. 21). Tal fato permite com que nosso autor desvende "os preconceitos ideológicos, os imperativos, as perspectivas e os modos do discurso orientalista” (SIMAS, 2007, p. 102). Eça, no entanto, vai além: não só demonstra a limitação do pensamento europeu acerca do asiático e desnuda o interesse do velho continente em se utilizar desta imagem a fim de legitimar sua política imperialista, mas tenta, por vezes, fazer a "reflexão em mão dupla" (OLIVA, 2008, p. 76) simulando como o asiático enxerga o europeu.

\footnotetext{
${ }^{61}$ No item dedicado a A Correspondência de Fradique Mendes tentaremos esclarecer o que esta expressão significa.
} 
Diferentemente dos textos da década de 70, não se nota uma posição eurocêntrica ou etnocêntrica. Eça trabalha a Europa e o Extremo Oriente de maneira similar: destaca as qualidades, critica e ironiza ambos. Uma das questões sempre destacadas pelo romancista português é a incompreensão mútua entre ocidentais e orientais. Não apenas isso, mas também a falta de interesse mútuo. Desta percepção notamos que a questão do aprendizado, da troca de conhecimento parece prefigurar como uma questão relevante a Eça. Pela falta de interesse entre Europa e Extremo Oriente, um nada aprende com o outro; Oriente e Ocidente não enxergam na alteridade um caminho para o conhecimento. Aí se encerra, entendemos, a grande crítica de Eça nos textos da década de 90.

Deste modo, é nítida a transformação das representações e, inferimos, das ideias de Eça de Queirós ao longo dos anos. As posturas adotadas são bastante diversas e demonstram um aprimoramento no exercício de enxergar o "Outro" enquanto respeitável. Acreditamos que, no século XIX, poucos desenvolveram esse raciocínio, o que faz com que possamos destacar a figura de Eça de Queirós não só no cenário lusófono, como também no cenário europeu. No capítulo seguinte, vamos analisar três obras ficcionais de Eça, nomeadamente, O Mistério da Estrada de Sintra (1870), O Mandarim (1880) e A Correspondência de Fradique Mendes (1900) e verificar como a representação do Extremo Oriente se dá nessas obras, vendo em que ponto elas se aproximam ou se afastam das representações identificadas nesse capítulo. 


\section{O EXTREMO ORIENTE NAS OBRAS FICCIONAIS DE EÇA DE QUEIRÓS}

O Extremo Oriente está presente nas obras ficcionais de Eça de Queirós mais do que se pode imaginar. Mas, para identificá-lo, é preciso ler com atenção seus textos, uma vez que, à exceção de $O$ Mandarim, o Extremo Oriente não é objeto central de nenhum de seus escritos. Aparece escondido em cenas, por vezes, secundárias ou em descrições de cenários. No entanto, poucas são as obras que não apresentam nenhuma referência, mesmo que furtiva, àquela região do planeta.

Se ampliarmos nosso escopo ao Oriente, incluindo regiões da cultura árabe e islâmica, as referências orientais na obra de Eça se ampliam muito e, consequentemente, se tornam mais evidentes. Conforme dissemos no capítulo inicial deste trabalho, a viagem feita por Eça ao Egito, Palestina e Alta Síria, em 1869, acompanhando o Conde de Resende, lhe rendeu material para inúmeros contos e trechos de obras. Essas anotações de viagem, Eça usou ao longo de toda sua carreira. Diz Campos Matos que desse "material [...] sairia depois A Relíquia, um capítulo da Correspondência de Fradique Mendes, as recordações de Malta utilizada n'O Mistério da Estrada de Sintra e a visão do deserto do conto Santo Onofre" (1988, p. 219-220). Se olharmos as datas das obras, temos $O$ Mistério da Estrada de Sintra, primeiro romance de Eça, de 1870; A Relíquia de 1887; A Correspondência de Fradique Mendes, obra semipóstuma, com trechos publicados ao longo da vida de Eça, mas reunidos e publicados como um texto único em 1900, pouco após sua morte; e Santo Onofre, parte da Lenda dos Santos, que foi publicado somente em 1912 por Luís de Magalhães em Últimas Páginas, mas foi redigido, de acordo com o que pode se depreender de sua correspondência, na década de 90, sua última década de vida ${ }^{62}$.

\footnotetext{
${ }^{62}$ Em carta a Oliveira Martins datada de 17 de abril de 1893, Eça escreve: "interrompi o S. Frei Gil, para me devotar a Santo Onofre. Não creio que conheças este ilustre solitário - porque não há bem a certeza de
} 
O Extremo Oriente é representado fortemente em três obras: $O$ Mistério da Estrada de Sintra (1870), O Mandarim (1880) e A Correspondência de Fradique Mendes (1900). Nos itens seguintes deste capítulo apresentaremos análises destes textos e, portanto, não nos deteremos por enquanto. Entretanto, outras obras importantes de Eça apresentam referências significativas do Extremo Oriente.

Por exemplo, em $O$ Crime do Padre Amaro, cuja primeira versão data de 1875 e a sua versão definitiva de 1880, no capítulo III, Amaro, ainda nos tempos de seminário, ouvia "no refeitório, diante do escasso caldo de hortaliça, quando o regente de voz grossa começava a ler monotonamente as cartas de algum missionário da China ou as Pastorais do senhor bispo[...]" (QUEIRÓS, 2000b, p. 149). Embora sejam apenas cartas, pelas quais Amaro não demonstra interesse, tais referências nos remetem às missões religiosas da Europa no Oriente. Tais missões, uma intensa ação ocidental naquela região desde o tempo das Grandes Navegações, foram responsáveis, durante principalmente os séculos XVI e XVII, pelos estudos de línguas e culturas dos povos orientais $^{63}$. Recordando as palavras de António Manuel Hespanha, os missionários foram responsáveis pelo verdadeiro "saber colonial" português durante séculos (HESPANHA, 1999, p. 19). Tais ações religiosas mantinham-se ainda como um intenso ponto de contato entre o Ocidente e o Oriente no século XIX.

No capítulo XXI, da mesma obra, aparece o seguinte trecho:

Amélia sabia que, pelo menos uma hora, tudo seriam façanhas da Janota, pontarias fabulosas contadas em mímica, com imitações de vozes de pássaros, e pum, pum de fuzilaria. Ou então era descrições das caçadas selvagens que ele lera com gula - a caça ao tigre do

que ele jamais existisse. Não da sua vida, que a não tem, mas dos hagiológios, consegui extrair umas cem páginas, uma pequena plaquette, para ir acostumando o público a este neoflós-sanctorismo" (QUEIRÓS, 2000a, vol. 4, p. 282-283).

${ }^{63}$ Inúmeras são as pesquisas sobre a importância dos estudos feitos por religiosos portugueses no Extremo Oriente na intelectualidade europeia da época. Limitamo-nos aqui, a fim de ilustração, a lembrar que o primeiro dicionário de língua japonesa para uma língua ocidental, o Vocabvlário da Lingoa de Iapam, foi elaborado por missionários jesuítas portugueses em 1603. Acredita-se que o missionário João Rodrigues tenha sido o principal organizador da compilação. João Rodrigues também escreveu, em 1604, a Arte da Lingoa de Iapam, a primeira gramática da língua japonesa para uma língua ocidental. 
Nepal, ao leão da Argélia e ao elefante, histórias ferozes que arrastavam a imaginação da rapariga para longe, para os países exóticos onde a erva é alta como os pinheiros, o sol queima como um ferro em brasa, e entre cada ramagem reluzem os olhos duma fera... $\mathrm{E}$ depois, a propósito de tigres e de malaios, lembrava-lhe um história curiosa de S. Francisco Xavier, e ei-lo lançado, o terrível palrador, na descrição dos feitos da Ásia, das armadas da Índia e das estocadas famosas do cerco de Dio!

Foi mesmo um desses dias, no pomar, em que o abade, tendo começado por enumerar as vantagens que o cônego tiraria de transformar o pomar em terra de lavoura, acabara por contar perigos e valores dos missionários da Índia e do Japão - que Amélia, então em toda a intensidade dos seus terrores noturnos, falou dos ruídos que ouvia na casa e dos sobressaltos que lhe davam (QUEIRÓS, 2000b, p. 871-873, grifo nosso).

Neste trecho há, mais uma vez, a figura dos missionários portugueses, como os que passaram "perigos” na Índia e no Japão e na figura de S. Francisco Xavier ${ }^{64}$. Mas, o que mais chama a atenção do trecho não é o destaque das ações missionárias portuguesas, que também podem ser depreendidas, como no primeiro trecho, mas sim a conscientização de que as histórias contadas sobre o Oriente acabam por criar um mundo que "arrasta a imaginação para longe". Eça demonstra a valorização da construção de um local através do exotismo, como apontou Said em seu estudo aproximadamente um século após o autor de $O$ Crime do Padre Amaro ter redigido seu texto. Neste momento, não vamos nos alongar muito sobre esta questão porque não é a primeira vez que Eça utiliza desse recurso e dá destaque a este exotismo literário presente nas histórias europeias oitocentistas. Em O Mistério da Estrada de Sintra, tal recurso já tinha sido utilizado, como procuraremos demonstrar no item seguinte.

Outra obra que apresenta representações do Extremo Oriente muitas vezes despercebidas em meio a seu enredo é A Capital!. Esta obra foi publicada postumamente, em 1925, mas, conta-nos Campos Matos (1988, p. 111), teve sua escrita iniciada provavelmente em 1877. Devido a formulações e reformulações de outras obras

\footnotetext{
${ }^{64}$ S. Francisco Xavier (1506-1552), conhecido também como "Apóstolo do Oriente" é um dos mais importantes missionários portugueses. Um dos fundadores da Companhia de Jesus, foi missionário em diversos pontos do Oriente, como Malaca (Malásia), Goa (Índia), China e Japão.
} 
como O Crime do Padre Amaro, O Primo Basílio (1878) e Os Maias (1888), A Capital!

foi diversas vezes reiniciada e interrompida. Eça parece ter desistido da obra em $1881^{65}$, pois em carta a Ramalho Ortigão, datada de vinte de fevereiro, diz: "Interrompi a Capital estragando-a para sempre, creio eu, porque vejo agora que não poderei recuperar o fio da veia e de sentimento em que ela ia tratada". (QUEIRÓS, 2000a, vol. 4, p. 138). Na história de Artur, logo no primeiro capítulo, pouco após sua chegada a Coimbra para estudar, existe o trecho:

Então, para igualar estes génios, poder ter uma frase nestas discussões, Artur começou a devorar todos os livros de Teodósio, com uma sofreguidão confusa, indo de Petrarca à História da Revolução Francesa, de Santo Agostinho a Balzac, começando mesmo Hegel e precipitando-se logo para As Orientais e para a legião dos Românticos. E assim, pouco a pouco, perdendo o culto exclusivo pela personalidade do Cenáculo, elevou-se na admiração mais vaga de personagens da Arte ou da História, de épocas da Humanidade, de civilizações e de ideias. Entusiasmou-o a Meia Idade, as suas catedrais e os seus mosteiros, e o Reno gótico, com os seus castelos de Burgraves heroicos sobre píncaros de rochas; encantou-o o Oriente e as suas cidades eriçadas de minaretes, onde pousam cegonhas - as caravanas no Deserto, os jardins dos serralhos onde suspira, ao murmúrio da água, a paixão muçulmana; depois, atraiu-o a Renascença italiana, os seus decamerons galantes e as galas dos Papas; um livro de Arsène Houssaye deu-lhe por algum tempo a admiração exclusiva do século XVIII; depois, adorou a Boémia de Murger e de Gerard de Nerval... E tinha outros entusiasmos vagos por paisagens, heroísmos, teorias e atitudes — os rios sagrados da Índia, os corsários patriotas do Arquipélago grego, a regeneração das prostitutas, S. Bernardo em Clairvaux e Danton na Convenção. [...] desejava então ser pintor, lançar na tela o rico esplendor dos estofos, as decorações luminosas de um céu do Oriente, cenas de Shakespeare ou episódios grandiosos da História e nenhum destino humano the parecia igual ao de um Miguel Angelo, compondo o Julgamento Final, vivendo de pão e de água e, nos intervalos de repouso, escrevendo um soneto imortal (QUEIRÓS, 1992b, p.106107 , grifo nosso).

Deste trecho é possível depreender a importância dada aos estudos orientalistas

na formação intelectual dos estudantes da época. A busca de um homem de artes do século XIX, como Artur almejava se tornar, incidia em ser reconhecido como um

\footnotetext{
${ }^{65}$ Destacamos esta data baseada em sua correspondência publicada nas Obras Completas editadas por Beatriz Berrini (2000a). No prefácio da Edição Crítica de A Capital!, Luiz Fagundes Duarte (1992, p. 15) diz que o romance "foi composto provavelmente entre os anos de 1877 e 1884, e editado em 1925 com o título reduzido a A Capital e com critérios muito discutíveis".
} 
cosmopolita. E, para tanto, entre as diversas ciências que deveria dominar, está presente, também, o conhecimento das coisas do Oriente. Portanto, aqui há o destaque da ciência orientalista como uma das peças fundamentais para a sua colocação na elite intelectual. Em outras palavras, conhecer ritos, religiões, culturas e lendas oriundas do "leste" foi um caminho para o prestígio perante a sociedade artística da época. Tal fato não deixa de ser uma influência positiva do Oriente no Ocidente, uma vez que este busca aprender com aquele. Embora, muitas vezes os estudos orientalistas tenham sido realizados com o intuito de conhecer o "inimigo" para melhor dominá-lo, parece-nos claro não ser este o objetivo de Artur, jovem em busca da maior quantidade de conhecimento possível.

Vale também ressaltar a presença do imaginário oriental nas artes e, consequentemente, na sociedade europeia oitocentista. Destacamos aqui a referência a As Orientais (1829), de Victor Hugo e o interesse de Artur por Gérard de Nerval (18081855), um dos mais importantes escritores franceses do século XIX, que realizou, como tanto outros e como o próprio Eça, uma viagem ao Oriente em 1843, de onde surgiu seu interesse por religiões orientais e pelo ocultismo. Tal interesse se refletiu em sua obra ${ }^{66}$, e Nerval foi, assim como Hugo, um dos expoentes do orientalismo literário, bastante presente no romantismo francês. Ainda, quando o narrador destaca a passageira vontade de Artur de ser pintor, destaca-se "as decorações luminosas de um céu do Oriente", menção também reveladora de como as paisagens de terras Orientais inspiraram a pintura europeia da época.

Todo o interesse pelos estudos orientais é reforçado mais adiante, no mesmo capítulo, quando Artur conta empolgado a Cristina, sua prima de Oliveira de Azeméis, seu sonho de ter um leão domesticado como animal de estimação:

\footnotetext{
${ }^{66}$ Nerval publica em 1851 seu livro Voyage au Orient, em que descreve suas impressões de lugares como o Egito, o Líbano, a Síria e a Turquia.
} 
$\mathrm{Na}$ Índia, disse Artur, que é o país mais poético do mundo, os antigos reis eram sempre seguidos por leões familiares. - Ah, fez ela.

E aquele $a h$ ! tão seco, mostrando-a alheia, toda indiferente à Índia, e aos seus tiranos legendários, às pompas bárbaras dos cultos védicos, regelou subitamente aquela breve simpatia, que há pouco lhe dera o enternecimento dos seus olhinhos alegres. Quem se interessaria em Oliveira de Azeméis pela Índia e pelo Ramayana? E a certeza duma existência material e mesquinha, naquela terra de três ruas onde as pessoas passam, pesou-lhe na alma dolorosamente (QUEIRÓS, 1992b, p. 120).

Adiante, novamente, o entusiasmo de Artur com os assuntos do Oriente é novamente reforçado, quando diz; “[...] a matéria poética que lhe faltava [...] ia rebuscála pelos livros amados; e quando, depois de uma leitura das ORIENTAIS, imaginava o Oriente e o seu pitoresco lhe inspirariam estrofes ricas, ou depois de uma página de Vigny lhe vinha o entusiasmo de cantar o amor dos anjos" (QUEIRÓS, 1992b, p. 134). Mais uma vez, a presença do imaginário oriental nas elaborações artísticas do século de Eça de Queirós ganha destaque aqui.

Os elementos autobiográficos ${ }^{67}$ do autor na obra representam um dos pontos explorados pela crítica de A Capital!. Tomando isso como um pressuposto, não poderíamos imaginar que o grande interesse de Artur pelos estudos do Oriente não deixa de ser uma lembrança de Eça de seu próprio interesse pelos temas orientais desde seus tempos de estudante em Coimbra?

Outra obra de nosso autor que passaremos brevemente é $O$ Conde de Abranhos (1925). O Conde de Abranhos tem uma gênese similar a A Capital!. Foi redigido, provavelmente, no final da década de 70 , início de 80 , mas por questões diversas acabou nunca sendo publicado em vida. O texto veio a público somente em 1925, sob a

\footnotetext{
${ }^{67}$ João Medina, em Eça de Queiróz e o seu tempo, diz: "Compôs aqui uma das suas obras mais sombrias, penetrantes e autobiográficas, facto que a maioria dos estudiosos do escritor displicentemente desdenha ou ignora." (MEDINA, 1972, p. 138). Medina ainda cita Joel Serrão, que diz, em seu texto Cesário Verde: "Eça, através da sua autocaricatura que é Artur Corvelo, boticário e poeta de Oliveira de Azeméis, que sonha com a conquista de Lisboa, imagina-a de harmonia com a visão que os escritores franceses, principalmente Balzac, lhe tinham insinuado de uma cidade 'civilizada"' (SERRÃO, 1961, p. 61). E prossegue: "A insatisfação perante a vida citadina, que Eça também certamente experimentou, pô-la ele de modo magistral na sua personagem mais autobiográfica - Artur Corvelo, autocaricatura do romancista" (SERRÃO, 1961, p. 63)
} 
responsabilidade do filho de Eça, José Maria, que, de acordo com Campos Matos (1988, p. 155), interveio no texto paterno. O texto traz a biografia do Conde de Abranhos, "símbolo do político imbecil, hipócrita, oportunista, enfadonho e oco" (CAMPOS MATOS, 1988, p. 25). Sua vida é contada por Zagalo, seu secretário, tão tolo quanto seu superior. Escreve tentando exaltar a vida de seu chefe, mas acaba por apresentar "a total dimensão de um político ávido por Poder, videiro, trapaceiro, enfadonho e oco". (CAMPOS MATOS, 1988, p. 155).

Em determinado momento do texto, é dito:

O povo é como um desses monstruosos elefantes da Índia de que tenho ouvido contar: de uma pujança indomável e de uma simplicidade risível, o mundo inteiro, pela violência, não o pode obrigar a caminhar contra a sua vontade, e uma criança, pela astúcia, obriga-o a fazer cabriolas grotescas. (QUEIRÓS, 1958, vol. 3, p. 325).

Aqui, ao falar dos "elefantes da Índia" de que tem ouvido falar, o narrador acaba, mais uma vez, por demonstrar a presença de culturas orientais no imaginário europeu. Mais adiante, ao falar de diversos povos, Zagalo escreve:

Olhemos para a Inglaterra, esse disforme império artificial, maior que nenhum império clássico, feito de continentes distantes ligados entre si por fios telegráficos que pousam no fundo dos mares. Essa imensa mole mal equilibrada ameaça a cada momento dessoldar-se, aqui e além, na Índia, na África, na Oceania; uma oligarquia, mais orgulhosa do seu domínio universal que o patriciado romano, mal a pode manter unida pelo ferro e pelo ouro; e no entanto a revolução social, com um movimento preciso, compassado, geométrico, automático, vai preparando o fim dessa oligarquia obsoleta e a dissolução do imenso Império balofo. (QUEIRÓS, 1958, vol. 3, p. 356).

Aqui, ao se falar da Inglaterra, aparece não mais a relação Ocidente-Oriente pautada na religião, como em $O$ Crime do Padre Amaro, ou na relação cultural de $A$ Capital. Agora, se destaca a relação política. Aqui há claramente a intervenção política, a prática imperialista da Inglaterra em outras nações do mundo inteiro, não apenas do Oriente. 
Revelação da política imperialista europeia também estará em A Cidade e as Serras (1901). Esta obra, considerada uma obra semi-póstuma, uma vez que não estava inteiramente revista por Eça no momento de sua morte, é o resultado do "desenvolvimento de um conto intitulado Civilização, publicado na Gazeta de Notícias do Rio de Janeiro entre 16 e 23-10-1892” (CAMPOS MATOS, 1988, p. 147). Inicialmente visto como "simples exercício artístico" (SANTOS, 2011, p. 98), hoje a crítica é praticamente unânime quanto ao grande valor literário e a complexidade do livro $^{68}$ (SANTOS, 2011, p. 99). O enredo não é complicado: o narrador é Zé Fernandes. Conta a história de Jacinto, seu amigo, morador de Paris e que, quando jovem, era entusiasta do progresso e da civilização ${ }^{69}$. Passado os anos, Jacinto se encontra infeliz com toda a modernidade e, em uma viagem às serras de Tormes, descobre as alegrias da vida tranquila do campo.

No capítulo IV da obra, durante um jantar na casa de Madame de Trèves, em Paris, Jacinto e Zé Fernandes encontram o conde de Trèves, marido da Madame, e um banqueiro judeu chamado David Efraim, amante da mesma. Os homens de Madame de Trèves tentam convencer Jacinto a investir seu dinheiro na Companhia das Esmeraldas da Birmânia, empreendimento encabeçado pelos dois. No diálogo entre os três cavalheiros, todo o processo colonial europeu no sudeste asiático é desnudado. Reproduzo o excerto:

\footnotetext{
${ }^{68}$ António José Saraiva em Tertúlia Ocidental diz: "Em 1945, comemorando-se o centenário do nascimento de Queiroz, o autor da presente obra publicou um estudo sobre As Ideias de Eça de Queiroz em que se partia do princípio de que Eça de Queiroz era um escritor de ideia, mas só de certas ideias. De facto o lento desenvolvimento da mentalidade portuguesa tornava ainda actual em 1945 a caricatura que Eça fez da nossa sociedade em As Farpas, O crime do Padre Amaro e O Primo Basílio, obra que continuavam vivas graças à extraordinária arte do escritor. Todas as outras obras eram consideradas desvios da sua 'verdadeira' rota. [...] Por isso uma obra-prima como A Cidade e as Serras era julgada como insignificativa, ou como um 'regresso' a Júlio Dinis" (SARAIVA, 1995, p. 157).

${ }^{69}$ Pode-se entender "civilização", nesta época, genericamente, a partir do ponto de vista europeu, como uma sociedade que possuía uma cultura material, bélica e intelectual desenvolvida, sendo a sociedade europeia, mais especificamente a Inglaterra e a França, o paradigma, em detrimento a sociedades menos desenvolvidas tecnologicamente ou que, intelectualmente, não conseguiam "rivalizar com a [cultura] europeia" (GARMES, 2005, p. 66). Eça de Queirós se utilizou dessa palavra de diversas formas. Helder Garmes (2005) desenvolveu um estudo sobre este conceito para nosso autor, analisando diversos textos queirosianos.
} 
Num relance, rebuscando charutos sobre a mesa de limoeiro, compreendi que se tramava a Companhia das Esmeraldas da Birmânia, medonha empresa em que cintilavam milhões, e para que os dois confederados de bolsa e de alcova, desde o começo do ano, pediam o nome, a influência, o dinheiro de Jacinto. Ele resistira, num enfado dos negócios, desconfiado daquelas esmeraldas soterradas num vale da Ásia. E agora o conde de Trèves, um homem esgrouviado, de face rechupada, eriçada de barba rala, sob uma fronte rotunda e amarela como um melão, assegurava ao meu pobre Príncipe que no prospecto já preparado, demonstrando a grandeza do negócio, perpassava um fulgor das "Mil e Uma Noites". Mas sobretudo aquela escavação de esmeraldas convidava todo o espírito culto pela sua ação civilizadora. Era uma corrente de ideias ocidentais, invadindo, educando a Birmânia. Ele aceitara a direção por patriotismo...

- De resto é um negócio de jóias, de arte, de progresso, que deve ser feito, num mundo superior, entre amigos...

E do outro lado o terrível Efraim, passando a mão curta e gorda sobre a sua bela barba, mais frisada e negra que a de um rei assírio, afiançava o triunfo da empresa pelas grossas forças que nela entravam, os Nagaiers, os Bolsans, os Saccart...

Jacinto franzia o nariz, enervado: - Mas, ao menos, estão feitos os estudos? já se provou que há esmeraldas? Tanta ingenuidade exasperou Efraim: - Esmeraldas! Está claro que há esmeraldas!... Há sempre esmeraldas desde que haja acionistas! (QUEIRÓS, 2011, p.105)

Vale destacar a posição do narrador Zé Fernandes que, ciente dos fins que a interferência ocidental tinha naquelas terras, execra tais atitudes. Isso fica evidente com expressões como "medonha empresa que cintilavam milhões". Em contrapartida, há a ganância claramente exposta da elite capitalista europeia, resumida, no trecho, pela frase: "Há sempre esmeraldas desde que haja acionistas!".

Há de se notar, ainda, a diferença em que, por exemplo, a política imperialista europeia é tratada nos textos. Se em $O$ Conde de Abranhos, texto do final da década de 70, ela é apresentada, em A Cidade e as Serras, da década de 90, faz-se uma clara crítica a essa prática. Se lembrarmos dos textos jornalísticos que estudamos no capítulo anterior, esta passagem de A Cidade e as Serras vai diretamente ao encontro das ideias proferidas em suas crônicas da década de 90. Lembrando rapidamente da crônica "a França e o Sião" de 1893, em que Eça ironiza:

Os países orientais são feitos para enriquecer os países ocidentais - e por isso com os Egiptos, os Tunes, os Tonquins, as Cochinchinas, os 
Siãos (ou Siões?) se fazem para a Inglaterra e para a França boas e pingues colónias. Eu sou civilizado, tu és bárbaro - logo, dá cá primeiramente o teu ouro e depois trabalha para mim" (QUEIRÓS, 2002, p. 368-369).

Não é exatamente isso que Eça está demonstrando, mais uma vez, em A Cidade e as Serras?

Referências similares a uma relação entre Europa e Extremo Oriente ainda poderão ser percebidas em outras obras, como em Os Maias (1888), onde há, no capítulo XIV (QUEIRÓS, 1958, vol. 2, p. 315), o quiosque japonês de Carlos e Maria Eduarda, ou, ainda, a menção à viagem de Carlos e Ega ao Japão, anunciado nos jornais como "esse delicioso país de onde nos vem o sol e a moda" (QUEIRÓS, 1958, vol. 2, p.476), mostrando mais uma vez, a influência do Oriente na sociedade europeia finissecular, além de tendências artísticas provenientes dessa influência, como o japonismo. Há também a referência aos "países maravilhosos do Oriente” (QUEIRÓS, 1958, vol. 1, p. 712) ou das “joias de luxo exótico" (QUEIRÓS, 1958, vol. 1, p. 710) da China no conto Singularidades de uma Rapariga Loura (1874) e a personagem do Tio Timóteo, que vivera na Índia e perdera a perna em uma caçada, do texto póstumo $A$ Tragédia da Rua das Flores $^{70}$ (1980), entre outros. Mas não trabalharemos aqui com esses textos, pois, a nosso ver, a análise de excertos, apesar de reforçar características apresentadas nos outros trechos, faria nossa análise demasiadamente repetitiva.

Destacamos apenas que, além de todos esses trechos que separamos em obras que abrangem vários momentos da carreira literária do autor de Os Maias, ainda são inúmeros objetos decorativos procedentes do Extremo Oriente em diversas obras. Não são raras as referência a gravatas ou lenços de seda da Índia, jarras da Índia, pratos de porcelana chinesa, vasos da China, frutas como os damascos secos do Japão, cigarros do

\footnotetext{
${ }^{70}$ Este texto é um esboço de um romance concebido em Newcastle entre os anos de 1877 e 1878 , de acordo com as informações presentes no Dicionário de Eça de Queiróz (1988, p. 603). Só foi publicado em 1980, quando os direitos autorais de Eça passaram a pertencer ao domínio público.
} 
Oriente, tinta da China, vaso do Japão, colchas da Índia ${ }^{71}$, entre outros tantos objetos, que demonstram a "franca utilização de elementos culturais [...] presentes no pano de fundo de muitas de suas descrições ficcionais." (FIGUEIREDO, 2005, p. 113). A utilização de tais objetos expõe não apenas as relações artístico-culturais entre a Europa e o Extremo Oriente, mas também evidencia uma tendência na decoração de interiores no fin-de-siècle. Objetos de origem ou de motivos orientais no ornamento de ambientes ou em utensílios domésticos indicavam refinamento, fineza. Quando Eça de Queirós insere tais utensílios em diversas obras, obviamente, não o faz gratuitamente. Aqueles se valem como indicativos de classe, ou seja, inserem as personagens dentro de uma classe social, no caso, a elite decadente portuguesa, nicho social ao qual Eça se debruçou. Em suma, estes objetos nas descrições de cenas das obras ficcionais de Eça funcionam, principalmente, como marcas sociais.

Ao analisarmos as representações do Extremo Oriente na obra queirosiana, acreditamos que três obras mereçam uma atenção maior. São as já citadas $O$ Mistério da Estrada de Sintra, O Mandarim e A Correspondência de Fradique Mendes, que, além de apresentarem passagens mais detidas do Extremo Oriente, estão localizadas em fases distintas de vida e carreira do nosso autor. Passaremos, então, a partir de agora ao estudo mais cuidadoso dessas obras.

\subsection{O EXTREMO ORIENTE EM O MISTÉRIO DA ESTRADA DE SINTRA}

O primeiro romance publicado por Eça de Queirós também foi a primeira representação do Extremo Oriente em suas obras ficcionais. Não podemos afirmar ser a primeira aparição do Oriente nos escritos de Eça, uma vez que, a essa altura, já havia

\footnotetext{
${ }^{71}$ Objetos de origem oriental retirados das páginas dos seguintes romances: O Primo Basílio, A Capital!, Os Maias e As Cidades e as Serras, excluindo referências similares que aparecem em obras ainda a serem analisadas nesse estudo.
} 
sido publicado há algumas semanas o conto “A Morte de Jesus", inspirado pela viagem que fizera no ano anterior às terras do Egito, Palestina e Alta Síria. Como dissemos, desta viagem Eça também possuía suas anotações, publicadas apenas vinte e seis anos após morte. Estas foram largamente utilizadas para desenhar alguns cenários de $O$ Mistério da Estrada de Sintra ${ }^{72}$ (1870).

O Mistério da Estrada de Sintra, embora muitas vezes seja "hoje desprezado" (MÓNICA, 2009, p.110) por parte da crítica queirosiana, traz em si diversos elementos originais. Se não é completamente excluída da bibliografia queirosiana, normalmente dá-se pouca atenção a esta obra. Talvez, o que justifique tal atitude, seja o fato de não ter sido um texto concebido exclusivamente por Eça. Foi feito a quatro mãos com Ramalho Ortigão (1836-1915), sendo que vivia "um em Leiria, outro em Lisboa, cada um com uma resma de papel, a sua alegria e a sua audácia”, como apontam os próprios autores, no prefácio da $3^{\text {a }}$ edição, em 1884. Outro motivo que talvez explique o menor valor concedido a $O$ Mistério esteja na aparente distância entre o conteúdo desta com as demais obras queirosianas, principalmente às realistas. Ainda, Ofélia Paiva Monteiro nos lembra de que os próprios autores podem ter contribuído para tal posição desta obra em suas respectivas bibliografias, uma vez que "já nas Farpas consideravam ‘deplorável' esse livro que tinham escrito, onde a 'insignificância literária' se juntava a “esterilidade moral”" (MONTEIRO, 1985, p.15) ${ }^{73}$. No prefácio de 1884, os escritores voltam a tratar seu livro como "execrável", em que não se "deseja, nem ao seu pior inimigo, um livro igual.” (QUEIRÓS e ORTIGÃO, p. 8). Mais para frente, no entanto, relativizam esta falta de valor literário, classificando o livro como "uma lição de independência” (QUEIRÓS e ORTIGÃO, p. 9).

\footnotetext{
${ }^{72}$ Sobre a relação entre as anotações de viagem e as descrições de $O$ Mistério da Estrada de Sintra, conferir o cotejo realizado por João Gaspar Simões, 1973, p. 238-265.

${ }^{73}$ Os trechos citados por Ofélia Monteiro neste excerto, de acordo com a referência presente em seu artigo, foram retirados de Uma Campanha Alegre. Das Farpas, vol. II, $3^{\text {a }}$ ed. Porto: Lello \& Irmão, 1943, p. 170.
} 
Ao se estudar a história por trás da criação do livro e o diálogo que se estabelece com outras obras desta fase inicial de Eça, como as crônicas do Distrito de Évora, os textos das Prosas Bárbaras e As Farpas, percebe-se que esta obra foi essencial para o desenvolvimento de Eça enquanto escritor.

Este texto também é fundamental para nossos objetivos, uma vez que o trecho que mostra o Extremo Oriente apresenta inúmeros elementos caracterizadores de uma relação existente entre o Ocidente e o Oriente, além de estabelecer diálogos com o Extremo Oriente d'As Farpas, estudadas no capítulo anterior. Antes de entrarmos na análise do trecho propriamente dito, julgamos ser necessário breves considerações acerca da obra como um todo.

O Mistério da Estrada de Sintra foi uma obra composta por Eça e Ramalho a fim de "acordar [...] a berros" (QUEIRÓS e RAMALHO, 1951, p. 7) uma Lisboa “adormecida pela rotina e pelo melodramatismo oco" (MONTEIRO, 1895, p. 16). Buscando elementos na literatura estrangeira, principalmente francesa ${ }^{74}$, além da própria “alegria e audácia” (QUEIRÓS e ORTIGÃO, p. 8), Eça de Queirós e Ramalho Ortigão criaram uma paródia dos romances-folhetins. O principal objetivo era abalar a inércia mental e a literatura pouco original produzida e consumida em Portugal $^{75}$. A composição da obra se dá através de inúmeras cartas de vários remetentes, todos

\footnotetext{
${ }^{74}$ Ofélia Paiva Monteiro se dedica às possíveis fontes de inspiração de Eça e Ramalho, dando destaque aos contos de Edgar Alan Poe (1809-1849) e romances de Émile Gaboriau (1832-1873). Andrea Trench de Castro faz um estudo comparativo do texto de Eça e Ramalho com o texto Les Mystères de Marseille (1867), de Émile Zola. É destacado por ambas o aspecto original que Eça e Ramalho conseguiram dar ao seu romance, dando um "caráter híbrido" (MONTEIRO, 1985, p. 22) de notícia e ficção a um texto "fora de todos os moldes até seu tempo consagrados" (QUEIRÓS e ORTIGÃO, p. 9).

${ }^{75}$ Retomando mais uma vez o prefácio da terceira edição, os autores lembram-se da: "tristeza da grande cidade que [...] cabeceava de sono ao som de um soluçante pout-pourri dos 'Dois Foscaris' [...]. O nome de Flaubert não era familiar aos folhetinistas. Ponson du Terrail trovejava no Sinai dos pequenos jornais e das bibliotecas econômicas. O Sr. Jules Claretie publicava um livro intitulado....(ninguém hoje se lembra do título) do qual diziam comovidamente aos crítico: - Eis uma obra que há de ficar! [...]"(QUEIRÓS e ORTIGÃO, 1951, p. 8-9). Jaime Batalha Reis, no prefácio das Prosas Bárbaras também destaca as "fórmulas aceites e classificadas pelos aplausos dum público hereditariamente satisfeito" (REIS, 1958, p. 544). N'As Farpas, mais uma vez, Eça retoma o marasmo intelectual português da época, quando fala de uma literatura "sem ideia, sem originalidade, convencional, hipócrita, falsíssima" que "não exprime nada". (QUEIRÓS, 2000a, vol. 3, p. 670).
} 
identificados apenas por abreviações, como, por exemplo, Z., A.M.C, Doutor ***, etc. O Mistério da Estrada de Sintra se inicia com uma carta de 23 de julho de 1870, enviada ao redator do jornal lisboeta Diário de Notícias pelo hipotético Doutor ***, que conta a história de seu sequestro na estrada de Sintra juntamente com um amigo, F., para a verificação do estado de um inglês supostamente morto. Tal relato foi publicado na parte do jornal dedicado a ficção, o que causou uma sensação de dúvida nos leitores. Seria o fato ocorrido em Sintra real? Se sim, por que estaria publicado na parte dedicado à ficção?

Era esta sensação de dúvida que os autores queriam para sua obra. Uma obra que deixava a imprecisão em seus leitores se estavam lendo um noticiário ou um folhetim. Ou, nas palavras de Ofélia Paiva Monteiro:

O romance montou-se sobre um jogo humorístico com o público, que consistiu fundamentalmente, como todos sabem, em fazer passar por relato de eventos reais uma narrativa forjada com ingredientes propositadamente rocambolescos, cujo cariz ficcional só in extremis se denunciava explicitamente aos leitores crédulos (MONTEIRO, 1985, p. 16, grifo da autora).

Portanto, o verdadeiro "Mistério da Estrada de Sintra” criado por Eça e Ramalho não era, de fato, a história da enigmática morte de um inglês em uma casa em Sintra, mas sim a dúvida quanto à legitimidade daquelas palavras publicadas naquele jornal. Logo, as histórias que explicam a morte do inglês poderiam prender a atenção dos leitores consumidores de folhetins, mas o que causaria o alvoroço desejado pelos autores na sociedade lusitana seria a dúvida da veracidade daquele relato.

Um leitor atento poderia "desmascarar" as intenções dos autores. Por isso, a fim de preservar esse "jogo humorístico" e de atiçar a dúvida entre o real e o fíccional em seus leitores, Eça e Ramalho introduziram a personagem denominada Z., que aparece como o "leitor crítico dos folhetins" (MONTEIRO, 1987, p. 6), identificando todas as incoerências nos fatos descritos e mostrando todas as características folhetinescas nos 
relatos. Z. é um dos pilares de sustentação do "jogo" montado pelos escritores, pois "a partir da carta de Z. houvera o envolvimento de um Leitor na narrativa" (CASTRO, 2012, p. 119). Este leitor ao mesmo tempo revela todo o segredo, uma vez que mostra sua ficcionalidade ao apontar as brechas narrativas, e o mantém, já que a figura de um leitor mantém aberta a possibilidade das cartas serem verídicas.

Z. também chama a atenção da crítica, pela similaridade com o pseudônimo usado por Eça nos textos do Distrito de Évora, A. $Z^{76}$. Gaspar Simões (1971, p. 249), o primeiro a atentar para tal similaridade, lê essa semelhança como Eça sendo Z. Ou seja, A.Z. e Z. seriam a mesma pessoa ${ }^{77}$, uma vez que desempenham funções semelhantes: “criticar a literatura circundante e o meio literário (apático) da época, instalando uma ‘semente' crítica no leitor crédulo" (CASTRO, 2012, p. 87). Gaspar Simões acredita que Eça, para ele autor da maior parte do Mistério, como retomaremos adiante, tenha introduzido Z. para fazer uma autocrítica lúcida. Cito:

A consciência literária de Eça de Queirós não podia calar, de facto, as rocambolices do romance que tinha entre mãos. [...] E, lucidamente, põe-se a analisar, como crítico, o que ele próprio concebeu e realizou. [...] Tendo lido as páginas que escrevera, ele, Eça, aprendiz de romancista, notara nelas deficiências e inverossimilhanças absolutamente imperdoáveis. (1973, p. 252-253, grifo do autor).

Embora seja incontestável a similaridade entre os pseudônimos Z. e A.Z, e o fato de, realmente, exercerem um papel similar em seus respectivos textos, não podemos negar a importância de Z. enquanto peça-chave do jogo proposto pelos autores.

\footnotetext{
${ }^{76}$ A. Z. foi um dos pseudônimos utilizados por Eça para assinar alguns textos do Distrito de Évora, jornal de caráter oposicionista ao governo de Joaquim António de Aguiar. Nele, Eça, diretor e redator-chefe, considerado pela crítica o provável responsável por tudo que era publicado, escreveu sobre diversos assuntos, como política internacional, política interna, crônicas, etc. Por vezes, escrevia, por exemplo, como um correspondente do jornal em Lisboa, o que serviu para exercitar a escrita na pessoa do outro. Eça conduziu o jornal de janeiro a agosto de 1867 , totalizando 66 números publicados. A. Z. provem das últimas letras de seu nome, Eça de Queiróz. Outros pseudônimos adotados foram A. M. e A. G. M.

${ }^{77}$ Para João Gaspar Simões, não apenas Z. era um heterônimo de Eça de Queirós como também o Doutor***. Da mesma forma, o crítico relaciona a personagem F. à figura de Ramalho. Cito: "Eça de Queirós aproveita logo as sugestões da 'Carta de F. ao Doutor' e junta-lhe uma nova carta[...]. Nesta, o médico - ou seja, Eça de Queirós - traço por traço, faz o retrato do Ramalho, fingindo estar a retratar F. [...]" (SIMÕES, 1973, p. 251)
} 
Portanto, parece-nos que Z. ganha mais importância na trama como o pilar do verdadeiro mistério criado, quer dizer, da dúvida da veracidade ou da ficcionalidade daquela narrativa, do que como um heterônimo que Eça se utiliza para fazer sua autocrítica.

A partir da primeira intervenção de Z., sucede a carta de F., o amigo sequestrado juntamente com o médico. Esta carta, cheia de "incongruência e exageros" (MONTEIRO, 1987, p. 6) também só vem acrescentar alguns fatos aos eventos bastante dúbios descritos pelo Doutor***. Em seguida, vem mais uma carta de Z., que acusa o Doutor*** e F. de cumplicidade no crime e a elaboração da carta como artifício de fuga de sua responsabilidade. Agrega-se, ainda, o fato de Z. se dizer amigo de A.M.C, um rapaz honesto que aparecera na cena do suposto crime. Z. usa sua amizade com A.M.C e o seu correto caráter para embasar sua acusação de farsa do Doutor *** e de F., continuando, assim, o "jogo humorístico" e deixando o leitor cada vez mais em dúvida quanto a veridicidade ou a falsidade do que se lê.

Dessa maneira o Mistério é construído. Com as cartas do Doutor *** e de F, estrategicamente intercaladas pelas de Z., Eça e Ramalho terminam a "primeira parte" do romance, em que só suspeitas são apresentadas aos leitores. A partir deste ponto, começa o segundo bloco de cartas. O bloco da revelação, ou seja, onde se "desenlaçam todas as incógnitas” (MONTEIRO, 1988, p. 408). Nesta segunda parte, com a atenção dos leitores devidamente presa, os autores se afastam dos elementos que geravam a dúvida da veracidade dos fatos narrados e apresentam elementos muito mais próximos do romance-folhetim comum.

$\mathrm{Na}$ segunda parte das cartas [...] se desencerram todos os mistérios criados e se carregam as tintas na narrativa folhetinesca: surgem elementos exóticos, [...], amores ensandecidos, vinganças desmedidas, crimes passionais, reviravoltas inesperadas, fugas inconsequentes, e tantos outros elementos celebrizados por Alexandre Dumas e Eugène Sue, dos quais não fica excluída a importantíssima cadeia temática observada nos grandes "mistérios": o crime, o arrependimento, a 
culpa, a punição, a redenção, e o final moralizador. (CASTRO, 2012, p. 122-123).

Neste novo bloco de cartas, Doutor ***, F. e Z. desaparecem e ganham voz as outras personagens. O primeiro a falar é o Mascarado Alto, um dos sequestradores do Doutor $* * *$ e F.. Sucedem-se as cartas de A.M.C.; da Condessa de W., a amante de Capitão Rytmel, o morto; e novamente de A.M.C. Por fim, há a "última carta", publicada em 27 de setembro, aproximadamente dois meses após a primeira, que consiste em um parágrafo assinado por Eça e Ramalho revelando que tudo que foi publicado sobre aquele mistério era apenas invenção dos dois jovens escritores portugueses.

Conforme destacado pelos próprios autores em seu prefácio para a edição de 1884, os dois escritores não elaboraram toda a obra juntos. Estando, "um em Leiria, outro em Lisboa" (QUEIRÓS e ORTIGÃO, 1951, p.9) a autoria das cartas enviadas foi dividida entre os amigos. No entanto, parece ser consenso entre a crítica que essa divisão não foi igualitária. Os críticos que se debruçaram sobre a gênese ou o enredo de O Mistério da Estrada de Sintra parecem convergir para o fato de "ao contrário do que se poderia depreender do depoimento dos dois escritores, o romance não foi escrito, alternadamente, ora por Ramalho ora por Eça." (SIMÕES, 1973, p. 246). O primeiro a tentar separar quais trechos cabiam a pena de Eça e quais correspondiam a elaboração de Ramalho foi José Sampaio Bruno, que escreveu, em A Geração Nova (1885), um estudo sobre Eça, que também foi o primeiro estudo acerca da gênese do Mistério da Estrada de Sintra. Nele, Sampaio Bruno diz: "destacamos para Eça de Queiroz a Exposição do Dr.***; a Intervenção de Z.; a Nota que segue a carta de F.; a Segunda carta a Z.; a Narrativa do mascarado alto; e A confissão dela; enquanto a Ramalho Ortigão pertencem as Cartas de F...ao Médico; As Revelações de A.M.C. e a parte em 
que Concluem as Revelações de A.M.C.” (BRUNO, 1885, s.p. apud QUEIRÓS e ORTIGÃO, 1951, p. 250) ${ }^{78}$

João Gaspar Simões, em Vida e Obra de Eça de Queirós também destaca a maior participação de Eça em relação a Ramalho na confecção da obra, ao dizer que “apenas três capítulos de 'O Mistério da Estrada de Sintra' são do punho de Ramalho" (SIMÕES, 1973, p. 247), mas sem especificar quais seriam estes capítulos. Provavelmente, ele se referia aos mesmos três trechos destacados por Sampaio Bruno.

Ofélia Paiva Monteiro lembra que

não é possível determinar com exactidão total quais as partes do romance que cabem a Eça ou a Ramalho. Razões várias se conjugam para que se atribuam habitualmente à mão de Eça as cartas do Doutor***, A Narrativa do Mascarado Alto, A Confissão Dela; provavelmente pertencer-lhe-ão ainda as intervenções de Z. (MONTEIRO, 1988, p. 409).

Na mais recente biografia de Eça que conhecemos, de Maria Filomena Mónica, a autora, retomando os críticos que também citamos acima, lembra que "a grande maioria das páginas foi escrita por Eça.” (MÓNICA, 2009, p. 105).

Nosso recorte compreende a parte IV da Narrativa do Mascarado Alto, o primeiro relato da segunda parte do romance e o mais longo de toda a obra. Uma vez que a crítica é unânime este atribuir este trecho à pena de Eça, a inclusão desta obra em nosso estudo estaria justificada. As representações do Extremo Oriente se dão de duas formas. A primeira, com pequenos elementos decorativos em descrições de cenas, como uma “cadeira indiana” (QUEIRÓS e ORTIGÃO, 1951, p. 96); “punhal de forma curva do Indostão" (p. 133), "bule do Japão" (p. 156), “sofá com um abandono asiático" (p. 209), entre outros. Como já falamos no primeiro item deste capítulo, tais referência aparecem em inúmeras obras de Eça, ao longo de toda sua carreira literária, mostrando

\footnotetext{
${ }^{78} \mathrm{O}$ trecho de Sampaio Bruno aqui destacado foi reproduzido pelos editores na "nota dos editores" presente na edição de 1951 de O Mistério da Estrada de Sintra, publicado pela editora Lello \& Irmão, sem referências a páginas.
} 
como a presença de objetos orientais representava refinamento na sociedade europeia oitocentista. A segunda é um episódio ocorrido na Índia, narrado pelo Capitão Rytmel, parte que analisaremos a seguir.

Para entender o trecho analisado, no entanto, é necessário que façamos o resumo dos acontecimentos narrados pelo Mascarado Alto. Este é primo da Condessa de W. ${ }^{79}$, que, devido a sua repentina fragilidade física, é convencida por seu primo e seu marido, o conde de W., a fazer uma viagem a Malta. Em Gibraltar, onde esperam o navio com destino a Malta, conhecem Rytmel, capitão inglês, "galã aureolado de romanesco: louro; delicado; bravo e melancólico" (MONTEIRO, 1985, p. 13) que mantém um relacionamento amoroso com Carmén Puebla, cubana, casada com D. Nicázio Puebla e marcada pelos seus ciúmes em relação ao seu amante inglês. Rytmel e a Condessa de W. se apaixonam e esta relação faz com que se desencadeiem todas as tragédias subsequentes: a tentativa de assassinato do Capitão Rytmel por Carmén, motivada por ciúmes; a tentativa de fuga do capitão e sua amante portuguesa a Alexandria; o duelo entre Rytmel e o Mascarado Alto; a morte de Carmen Puebla; a separação da Condessa de W. e o capitão inglês; a visita deste a Portugal e a sua misteriosa morte em Sintra.

O trecho que nos interessa antecede a maior parte desses acontecimentos típicos de folhetim. Antes da consolidação do relacionamento entre o Capitão Rytmel e a Condessa de W., é narrada uma caçada ao tigre realizada na Índia, momento em que o capitão inglês e Carmen Puebla tem seu primeiro envolvimento. No entanto, o Mascarado Alto faz uma interrupção em sua narrativa e reproduz um trecho das anotações de viagem de Rytmel em sua carta. Logo, o narrador de todo o episódio

\footnotetext{
${ }^{79}$ Ao longo desse capítulo, nos é informado que o nome da Condessa é Luísa. E não são poucas as semelhanças dessa Luísa, com a Luísa de $O$ Primo Basílio (1878). Além do mesmo nome, as descrições físicas são semelhantes: a Condessa tem "admiráveis cabelos louros e espessos; [...] olhos dum azul profundo como o da água do mediterrâneo" (QUEIRÓS e ORTIGÃO, p. 88), enquanto a Luísa de $O$ Primo Basílio possui um "cabelo louro", um "perfil bonito", e "uma brancura renta e láctea" (QUEIRÓS, 2004, p. 53). Ambas têm um casamento estável, embora monótono, e têm uma paixão por romances. Este fato as conduzirá às suas tragédias pessoais. Ou seja, acreditamos não ser equivocado supor que a Luísa de $O$ Mistério funcionou para Eça como um protótipo da Luísa de $O$ Primo Basílio.
} 
indiano é o militar inglês. Desde a entrada do Capitão Rytmel na Narrativa do Mascarado Alto, o episódio da Índia é anunciado. Estas chamadas, além de criar as expectativas do leitor em relação ao episódio em si, servem para construir a imagem de Rytmel como herói de folhetim "prestigiado por um halo de heroísmo vivido na mítica Índia” (MONTEIRO, 1985, p.13). A caçada ao tigre na Índia é apresentada como um "romance", adorado pela Condessa de W. Quando o Mascarado Alto fala de sua prima pela primeira vez a Rytmel, diz: “É a condessa de W. Parte para Malta amanhã no paquete. A bordo levar-lhe-ei o meu amigo para a entreter contando-lhe histórias da Índia. Adora o romanesco aquela pobre condessa!" (QUEIRÓS e ORTIGÃO, 1951, p. 95, grifo nosso). Mais adiante, quando fala à Condessa do capitão inglês, diz: “Arranjeilhe um romance, um lindo romance, prima. [...] Um romance onde se caçam tigres com rajás, onde há bayaderas, florestas de palmeiras, guerras e elefantes...” (QUEIRÓS e ORTIGÃO, 1951, p. 95). No jantar, já no navio em direção a Malta, acontece o primeiro encontro da Condessa de W. com o capitão Rytmel. Neste instante, ela diz: "Meu primo disse-me, Captain Rytmel, que tinha mil histórias da Índia para me contar. Já lhe digo que lhe não perdoo nem um tigre, nem uma paisagem. Quero tudo! Adoro a Índia, a dos Índios, já se vê, não a dos senhores ingleses”. (QUEIRÓS e ORTIGÃO, 1951, p. 96).

Portanto, ao ser anunciado ao longo do capítulo, o episódio da Índia é o tempo todo tratado com um "romance". Ganha ares de um romance-folhetim dentro de uma história já carregada das tintas folhetinescas (CASTRO, 2012, p.123). Aqui, obviamente, Eça está parodiando as produções literárias que faziam sucesso entre o adormecido público lusitano, mas também não deixa de mostrar claramente como existia o interesse pelo Oriente enquanto um lugar exótico, de histórias maravilhosas e fantasiosas, no imaginário da aristocracia europeia, aqui representada na figura da Condessa de W. Afinal, os elementos como tigres, palmeiras, entre outros que 
aparecerão mais adiante, só vêm a construir um "mundo mágico e exótico" ("Índia dos índios") num Oriente dominado pelas potências europeias (“Índia dos ingleses").

Adentrando agora o episódio em si, é narrada a saída da comitiva composta por Capitão Rytmel, D. Nicázio Puebla e sua esposa Carmen, além de "três malaios e um velho caçador [...], antigo brâmane [...], meio louco, que cantava estranhas melodias do Indostão, adorava o Ganges e dormia sempre em cima de uma palmeira" (QUEIRÓS e ORTIGÃO, 1951, p. 103) de Calcutá, capital da Índia britânica, até uma clareira no meio de uma floresta, onde encontram o tigre e o caçam. De Calcutá, nada é dito, apenas que há palácios e fábricas (QUEIRÓS e ORTIGÃO, 1951, p. 100), e todo o episódio se passa sob um cenário onde há um céu “pulverizado de luz" (QUEIRÓS e ORTIGÃO, p. 103), de “enormes estrelas cintilantes” (QUEIRÓS e ORTIGÃO, p. 108). Ou seja, é construído um cenário onde se destacam os elementos naturais, caracterizando um espaço exótico do ponto de vista europeu. Outro momento que vem a comprovar a busca do europeu pelo exótico no Oriente está logo na primeira fala da narração de Rytmel: "o sonho de todo o negociante que chega à Índia é caçar o tigre” (QUEIRÓS e ORTIGÃO, 1951, p. 102).

É de chamar a atenção também as personagens que formam a comitiva. As figuras orientais são apenas subservientes a Rytmel, inglês, e D. Nicazio Puebla, espanhol. Ou seja, aparece de maneira muito clara a relação do europeu colonizador dominador e do oriental dominado. Se lembrarmos, mais uma vez, dos textos jornalísticos estudados no capítulo anterior, não foi mais ou menos essa relação que Eça expôs, por exemplo, no artigo “A França e o Sião”, publicado na Gazeta de Notícias de 1893? Aqui, vinte e três anos antes de o artigo ter sido publicado no jornal carioca, Eça já expõe, talvez ainda involuntariamente, a relação dominador-dominado, colonizadorcolonizado em seu texto. 
Ainda, é de se notar que as poucas palavras dedicadas às personagens orientais são depreciativas, como "meio louco", que cantava "estranhas melodias". Há, também, uma passagem em que é dito: “O velho brâmane, que tinha trepado a uma palmeira, e de lá olhava, farejava, ordenava" (QUEIRÓS e ORTIGÃO, 1951, p. 105) . Aqui, nota-se que algumas descrições utilizadas acabam por animalizar a figura do caçador brâmane. Ao invés de dizer, por exemplo, "cheirava", é dito "farejava", expressão que deixa claro um desdém em relação ao brâmane. Ao lembrarmos que a voz narrativa deste trecho é a do Capitão Rytmel, acabamos por perceber que o que Eça expõe é a visão redutora que o europeu possuía dos povos orientais, além de ficar claro também, quando classifica o brâmane como "louco" e sua música como "estranha", que o capitão inglês, representante de toda uma sociedade colonialista, era incapaz de compreender e, porque não, de respeitar a cultura do povo que explorava.

O Extremo Oriente representado por Eça em $O$ Mistério da Estrada de Sintra é fruto de sua imaginação e, talvez, da sua carga de leitura. Diferente das outras paisagens descritas, como Gibraltar ou Malta, onde Eça realmente esteve alguns meses antes da elaboração do texto, a Índia nunca foi visitada por Eça e nos é impossível afirmar de onde Eça tirou suas descrições. João Gaspar Simões, no cotejo já mencionado das descrições de paisagens de $O$ Mistério da Estrada de Sintra com as anotações de viagem de Eça publicadas postumamente, afirma: “como nunca estivera na Índia nem nunca caçara tigres, Eça de Queirós, sem notas a recorrer [...] desce a farsa" (SIMÕES, 1974, p. 259). Embora seja uma leitura plausível, acreditamos que há ainda dois fatores que devem ser levados em consideração em relação a este trecho. Primeiramente, como falamos, este trecho funciona como um romance dentro do romance, ou seja, exerce a função de paródia das descrições de lugares exóticos difundidos na literatura europeia da época. Além disso, não há qualquer tentativa de descrever um lugar como, por 
exemplo, a cidade de Calcutá. O cenário é uma floresta, ou seja, um lugar bastante geral que não exigiria do autor a verossimilhança necessária para descrever, por exemplo, um lugar como Malta. Logo, não se demandaria do escritor muitas anotações específicas para tal descrição, exceto pequenos elementos naturais que diferenciassem uma floresta tropical indiana de uma temperada europeia, como as palmeiras. Não há, portanto, um desenho específico da Índia. Logo, não deve ter sido necessário recorrer a anotações de viagens ou textos de outros escritores, nem exigir demais de sua imaginação para desenvolver a Índia de $O$ Mistério da Estrada de Sintra.

Em nossa análise dos textos publicados n'As Farpas, destacamos a unilateralidade da relação Ocidente-Oriente nas crônicas, fato este que vai desaparecendo nos textos da década de 90 e ganhando forma de uma "via de duas mãos”. Em O Mistério da Estrada de Sintra, a mesma unilateralidade está presente. Como destacamos, o episódio oriental foi posto sob a voz de um inglês, o que nos permite ler tal cena como uma paródia do discurso colonialista europeu. Diferentemente de, por exemplo, A Cidade e as Serras, em que se vê uma crítica clara à política imperialista, aqui ainda não há tal postura. Assim como não há n’As Farpas. Lembramos que a postura anticolonialista d'As Farpas se dá muito mais pelas colônias orientais trazerem prejuízos a Portugal do que pela prática em si. No entanto, se n'As Farpas já havia uma semente crítica quando ligava, por exemplo, a política colonialista no Oriente à agiotagem, aqui também se mostra presente este germe na relação colonizador-colonizado ou nas descrições das personagens orientais feitas por Rytmel. Esta semente, da mesma forma que se desenvolveu nos textos jornalísticos, crescerá em suas obras ficcionais. Acima citamos A Cidade $e$ as Serras, da qual tratamos rapidamente no primeiro item deste capítulo. Porém, já em $O$ Mandarim, nosso próximo foco de análise, já se nota o desenvolvimento deste pensamento crítico. 
Como na maioria das outras obras ficcionais de Eça, o Extremo Oriente de $O$ Mistério da Estrada de Sintra não é o centro da história. Ele não ocupa mais de uma dezena de páginas de um dos capítulos centrais da trama. Este trecho passa despercebido pela maioria dos leitores, mas, numa leitura atenta, vários aspectos de uma relação Ocidente-Oriente podem ser notados. Não nos é possível afirmar se Eça expôs estes dados de forma consciente. É de se deduzir que algumas referências tenham sido feitas despropositadamente, uma vez que o seu principal objetivo era parodiar a literatura consumida por um Portugal apático. Portanto, assim como n'As Farpas, seu foco se encontra em Portugal e seus problemas. E, assim sendo, preocupações com o Oriente não são o foco do pensamento dos autores neste momento. No entanto, mesmo que consideremos as representações de $O$ Mistério da Estrada de Sintra como involuntárias, não há como negar que, já nelas, se podem depreender algumas questões que Eça trabalhará de jeito mais claro e aprofundado nos anos subsequentes, quer em seus textos jornalísticos, quer em seus textos ficcionais.

No próximo item, vamos trabalhar com $O$ Mandarim, publicado em 1880, ou seja, dez anos após a elaboração e publicação de $O$ Mistério da Estrada de Sintra.

\subsection{O EXTREMO ORIENTE EM O MANDARIM}

A obra mais citada e estudada quando levado em conta a presença do Extremo Oriente nos textos de Eça de Queirós é, sem dúvida, $O$ Mandarim, de 1880. Escrito em Angers, França, durante suas férias ${ }^{80}$, esta obra foi produzida em um mês (BERRINI, 1992, p. 19) e foi enviada ao Diário de Portugal no lugar do prometido original de Os

\footnotetext{
${ }^{80}$ Em 1880, Eça de Queirós era cônsul português em Bristol, Inglaterra.
} 
Maias, conforme se depreende de sua correspondência ${ }^{81}$. Este livro de classificação indefinida $^{82}$, embora curto e, à primeira vista, de enredo não muito original (SAPEGA, 2002, p. 444), mostra, em suas entrelinhas, uma complexidade artística e uma pluralidade de leituras que abrange diversos assuntos de sua época. Tal fato só vem a comprovar a importância do texto, que inicialmente foi visto como um descanso da severa análise do homem (QUEIRÓS, 1992a, p. 199), ou também como um texto que Eça elaborou meramente para cumprir o seu já atrasado compromisso com o jornal Diário de Portugal.

O enredo de $O$ Mandarim se passa parte em Portugal e parte na China ${ }^{83}$. Dois cuidadosos trabalhos acerca desta obra de 1880 apresentam reflexões sobre a China: o ensaio "O Mandarim Assassinado", de Coimbra Martins, presente na obra Ensaios Queirosianos (1967) ${ }^{84}$ e a "Introdução" da edição crítica de $O$ Mandarim feita por Beatriz Berrini (1992). No entanto, outras inúmeras leituras foram feitas do espaço dessa obra. Parece-nos importante iniciarmos nossa análise recordando os principais aspectos levantados por alguns desses estudos, uma vez que estes também embasam nosso pensamento. Portanto, num primeiro momento, vamos pontuar as principais

\footnotetext{
${ }^{81}$ Em carta a Ramalho Ortigão de vinte de fevereiro de 1881, pouco mais de meio ano após a publicação de $O$ Mandarim, Eça escreveu sobre Os Maias: "O contrato com o Malheiro era eu dar-lhe uma novela de vinte e cinco a trinta folhetins, com a remuneração de trinta libras, preço de amizade. - Apenas o trabalho ia em meio, reconheci que tinha diante de mim um assunto rico em caracteres e incidentes, e que necessitava um desenvolvimento mais largo de romance. Comuniquei isto ao Malheiro, que se alargou -e para fazer pacientar os leitores do jornal, presenteei o Diário com uma novela: o Mandarim (grátis!!!)" (QUEIRÓS, 2000a, vol. 4, p. 138, grifo do autor).

${ }^{82}$ Muito já se discutiu pela crítica se $O$ Mandarim deveria ser classificado como conto, conforme o próprio Eça escreve em sua carta-prefácio (1992, p. 197) à edição francesa de 1884; como novela, conforme trata em sua correspondência; ou como romance, uma vez que seria o texto extenso demais para ser classificado como conto, além de sempre ser posto como um texto a parte dos outros contos queirosianos. Não vamos, em nosso estudo, entrar nos méritos dessa discussão. Adotaremos aqui os termos "novela" e "narrativa".

${ }^{83}$ A descrição da China foi mais esquemática na primeira versão, publicada no Diário de Portugal. Maiores detalhes dos momentos de Teodoro em solo chinês foram acrescentados na versão em livro, publicada no mesmo ano. (BERRINI, 1992, 24-26)

${ }^{84}$ Coimbra Martins trata desta obra em outro texto, intitulado "Eça de Queróz et la littérature du Mandarin" (Eça de Queiróz e a 'literatura do Mandarim', tradução nossa). Este ensaio, escrito em francês, é apresentado como prefácio da tradução francesa de $O$ Mandarim feita por Michelle Giudicelli, publicada pela Editións de la Différence (1985). Aqui, utilizaremos apenas o ensaio "O Mandarim Assassinado" uma vez que ideias presentes nesses dois estudos são semelhantes.
} 
constatações dos estudiosos sobre esta obra de Eça. Com essas informações devidamente remontadas, passaremos então a nossa leitura de como o Extremo Oriente, mais especificamente a China, aparece neste texto queirosiano.

\subsubsection{ESTUDOS ACERCA DA CHINA DE O MANDARIM}

O enredo de $O$ Mandarim é pautado no chamado "paradoxo ${ }^{85}$ do mandarim”, ou seja, na problemática que envolve a seguinte questão:

Manter-se-ia o homem na virtude, se não temesse a sanção do crime? [...] [Tal crime] promete impunidade. Não havemos de esquecer, embora transpondo-as para o abstrato, as suas características essenciais: o delito é um assassínio; a vantagem, a riqueza; a vítima, um desconhecido; o local do crime, longe do criminoso; a causa da morte, uma ordem mental ou um simples gesto (MARTINS, 1967, p. 14).

Desde o emblemático e cuidadoso estudo de Coimbra Martins (1967), sabe-se que a fórmula de "tuer le mandarin ${ }^{86 " ~ n a ̃ o ~ e ́ ~ c r i a c ̧ a ̃ o ~ d e ~ E c ̧ a . ~ M u i t o ~ p e l o ~ c o n t r a ́ r i o . ~ E l a ~ j a ́ ~}$ havia aparecido em diversos textos da literatura, em especial, a francesa. Coimbra Martins nos lembra de alguns autores que podem ter servido de aproximação entre Eça e a questão do mandarim: Rousseau ${ }^{87}$; Chateaubriand (1802); Alexandre Dumas (pai) (1844); Vitu (1848); Monnier/Martin (1855); Louis Protat (1860); e, principalmente, Balzac e seu Le Père Goriot (1835), entre outros. Beatriz Berrini (1993, p. 199) ainda

\footnotetext{
${ }^{85}$ Como nos lembra Beatriz Berrini, em sua Introdução à edição crítica d' $O$ Mandarim: "a palavra 'paradoxo' é aqui usada no sentindo etimológico grego, de história inacreditável" (BERRINI, 1992, p. 40). 86 "Matar o mandarim" (tradução nossa).

${ }^{87}$ Coimbra Martins cita Rousseau, na verdade, para desmitificar o uso do "paradoxo do Mandarim" pelo filósofo francês. Por muito tempo, creditou-se a Rousseau o uso desta fórmula por causa de uma menção feita por Rastignac, protagonista de Le Pére Goriot de Balzac, sem se identificar o trecho em questão em nenhuma obra rousseauniana (Cf. BERRINI, 1992, p. 44). Entretanto, conforme nos esclarece Sérgio Nazar David: "Segundo Martins, Balzac atribuiu a Rousseau o que é de Génie du Christianisme [de Chateaubriand] pela semelhança da passagem do livro VI, capítulo 2, do livro de Chateaubriand, com a fala do vigário saboiano em Émile [ou d'la éducation] (Rousseau) [...]. Embora em 1930 Paulo Rónai já houvesse fixado a verdade sobre a origem do equívoco (Chateaubriand, e não Rousseau) em artigo 'Tuer le mandarin', publicado na 'Revue de Littérature Comparée' revista 'séria e de difusão relativamente larga' (MARTINS, 1967, p. 251), só em 1963 a Grand Larrouse Encyclopédique vai corrigir o erro [...]”. (DAVID, 2007, p. 119)
} 
nos lembra de Didier (1864). Está claro, então, que o paradoxo do mandarim já fora largamente utilizado pelos franceses ao longo de todo o século XIX, a ponto de a expressão "tuer le mandarin" já aparecer em dicionários da França desde 1866 (SAPEGA, 2002, p. 444).

Na literatura de Portugal também não é a primeira vez que a figura do mandarim "penetra [...] o imaginário português" (BERRINI, 1992, p. 41). De acordo com a Introdução da edição crítica de $O$ Mandarim, em 1871, no Almanach dos Estudantes para 1872, apareceu um poema escrito por A. Sérgio de Castro, um dos responsáveis pelo periódico citado (BERRINI, 1992, p. 41-42), intitulado "Um chinês e uma andaluza". Trazia onze quadras que falavam da paixão de um filho do Império do Meio por uma "sedutora andaluza" (BERRINI, 1992, p. 41).

No entanto, se, através da temática, $O$ Mandarim de Eça pode não chamar a atenção pela originalidade, o livro destaca-se pelas peculiaridades dadas por nosso autor a esta questão. A principal delas, e a que mais nos interessa, corresponde ao fato de Eça ter transportado seu protagonista, Teodoro, à China (MARTINS, 1967, p. 150).

Antes de avançarmos, vale destacarmos que, apesar do evidente cunho moral presente neste paradoxo que incita "a reflexão dos sujeitos sobre o desejo de poder dos homens" (LARA, 2012, p. 55), do ponto de vista dos estudos orientalistas, nosso enfoque neste trabalho, a questão do mandarim já representa em si uma forma de orientalismo no sentido que Said atribui ao termo. Uma vez que "por trás da fórmula de 'matar o mandarim', ditava que a vítima desconhecida tinha de estar a mais separada possível do criminoso em termos geográficos e culturais” (SAPEGA, p. 444), tal paradoxo representa um olhar depreciativo ao "outro", pois a figura do chinês não deixa de ser posta como descartável para a satisfação dos prazeres de seu executor, um ocidental. Ainda, o fato desse "outro" se ter cristalizado na figura de um chinês, também 
pode ser lido como uma demonstração do caráter redutor que o pensamento eurocêntrico concebia os orientais.

Eça de Queirós, como dissemos, levou seu protagonista, Teodoro, à China. Este fato já destaca a obra do autor português às suas "inspirações" francesas, que, de maneiras diferentes, trabalharam com o paradoxo. Quando percebemos este fato, é importante lembrar que Eça nunca visitou a China. Seu contato direto com a civilização chinesa se deu em Havana e algumas de suas impressões foram expostas no texto já analisado, A Emigração como Força Civilizadora. Ao recordamos rapidamente o conteúdo dessas páginas, Eça inicia por traçar, do ponto de vista do empregador, aspectos positivos da utilização de mão de obra chinesa em detrimento da de outros imigrantes, uma vez que trabalham mais, melhor e com baixa remuneração. Mas, depois destaca o desequilíbrio econômico causado por tal força de trabalho. Tal contato seria muito pouco para se desenhar uma China em sua obra, embora não tenha sido, como veremos, descartado. Portanto, é de se crer que a China de $O$ Mandarim seja construída, além dos poucos contatos diretos, a partir de suas leituras e de histórias contadas por amigos que tenham viajado ao império asiático ${ }^{88}$.

Coimbra Martins já detectara algumas possíveis fontes para o desenho da China nessa narrativa queirosiana. Lembra-nos que, desde sua publicação, algumas relações com o livro Les Tribulations d'un Chinois en Chine (1879), de Julio Verne, foram traçadas. Dessa questão, falaremos mais adiante. Beatriz Berrini (1993, p. 199) aprofunda a discussão iniciada por Coimbra Martins, refutando a ideia da inspiração de Eça em Verne devido à proximidade das datas de publicação. Traz ainda outros livros que Eça pode ter recorrido: La Chine Ouverte, sendo o original escrito em inglês (1845); China and its People (1873-1874); Pekin et l'intérieur de la Chine (1878); Le

\footnotetext{
88 "Dois grandes amigos de Eça de Queirós estiveram na China e deles o romancista terá ouvido narrativas pessoais de muito sabor: Eduardo Prado e o Conde de Arnoso" (BERRINI, 1992, p. 29).
} 
Chine et le Japon (1860), entre outros . Apesar de nos ser impossível determinar com exatidão a quais textos Eça recorreu, já que não há qualquer referência em sua correspondência, é de se imaginar que Eça tenha lido os livros destacados por Beatriz Berrini, uma vez que o romancista manteve "contato direto com um amplo leque do que se produzia em termo de publicações periódicas em Inglaterra” (MINÉ, 1986, p. 2324).

Outra possível fonte de inspiração de Eça, até onde sabemos nunca destacada pela crítica, pode ter sido Antero de Quental, apesar deste também nunca ter visitado a China e conhecê-la também através das letras e das histórias. Conforme dissemos na introdução desse trabalho, Antero de Quental é considerado pelos críticos ${ }^{89}$ como um dos inauguradores do orientalismo literário português no século XIX, junto com o autor de Os Maias. Antero "estudou avidamente o Budismo e as culturas Orientais" (FEITAIS, 2007, p. 123), logo, pode formar sua visão de Oriente, objeto que renderia outro valioso estudo. É sabido que Antero de Quental e Eça de Queirós puderam debater ideias sobre a China e o Oriente. Essa informação quem nos dá é o próprio autor de $O$ Primo Basílio, em seu texto "Um Gênio que era um Santo". Lá, o "discípulo" de Antero, diz:

Carlos Mayer andava nessa ocasião envolvido na ciência e cuidados de uma grande indústria de destilação - e a conversa rolou sobre máquinas, processos, fermentos, salários, lucros, milhões. Antero circulava ardentemente dentro daquelas questões de química, mecânica, economia, como se elas constituíssem a paixão suprema dos seus dias solitários. O ar do seu quarto de metafísico ficou em breve mais cheio de cifras, de vozes técnicas, que o de um escritório da City. Depois, talvez porque a esse tempo eu me preocupava com a civilização chinesa, deslizávamos a conversar da China. Carlos Mayer atacou rancorosamente o Império Florido. Antero, arrojando a manta, exaltou logo o Chinês, e a sua pedagogia, e a sua agricultura, e a sua arte, e a sua sociedade, e a solidez e pureza das suas instituições domésticas - com o saber miúdo e grave de um mandarim. (QUEIRÓS, 2000a, vol.3, p. 1775-1776, grifo nosso).

\footnotetext{
${ }^{89}$ Isabel Pires de Lima (1999, p. 149), António Manuel Hespanha (1999, p. 26) e Álvaro Manuel Machado (1983, p.73).
} 
Não nos é possível precisar a data de tal encontro. No entanto, pelas pistas deixadas por Eça ao longo do texto, é de se deduzir que tenha ocorrido perto da elaboração de $O$ Mandarim. Se aconteceu em Lisboa e $O$ Mandarim foi escrito em um mês, na França, podemos deduzir, a partir de sua "preocupação com civilização chinesa”, que, talvez, Eça já estivesse pensando em elaborar alguma obra que envolvesse o Império do Meio em sua trama. Apesar de ser apenas uma conjectura, tal fato serviria para acabar de vez com a imagem de uma trama improvisada que $O$ Mandarim adquiriu em seus primeiros julgamentos. Ainda, podemos pensar que foi justamente essa "preocupação com a civilização chinesa", que faz Eça se diferenciar de seus precursores do paradoxo do mandarim e levar seu protagonista ao território asiático. Também, se Eça de Queirós possuiu uma visão plural da China, como vimos em seus textos jornalísticos e veremos também aqui, Antero de Quental provavelmente colaborou para a cristalização desse seu olhar.

Como dissemos, de todas as possíveis inspirações para $O$ Mandarim, com certeza, Les Tribulation d'un Chinois en Chine, de Júlio Verne, foi o que gerou maior repercussão. O livro de Verne conta a história de Kin-Fo, jovem rico e entediado que, ao saber que ficara repentinamente pobre, pede para seu amigo, Wang, para lhe matar. No entanto, esta morte tem que vir inesperadamente para que nos "oitenta mil minutos" que lhe restariam desde o pedido até a data limite de sua morte, desfilassem "oitenta mil emoções, de modo que [...] eu possa gritar: vivi!" (VERNE, 1982, p. 89-90). Ao ter toda sua riqueza recuperada, Kin-Fo desiste do plano de morrer e vai pela China tentando fugir de seu amigo Wang e de sua morte.

Pelo enredo, pouco pode se aproximar Les Tribulation d'un Chinois en Chine com $O$ Mandarim. Por ter um protagonista rico, entediado e em busca de emoções, o enredo remeteria mais $A$ Cidade e as Serras, do que propriamente a $O$ Mandarim. No 
entanto, ainda na década de 80, Eça fora acusado, mais uma vez, de plágio, principalmente por semelhanças de descrições de Pequim e por "pormenores de vestuário, de bricabraque, de usos domésticos, de culinária” (MARTINS, 1967, p. 148). Quem nos traz essa informação é mais uma vez Sampaio Bruno em A Nova Geração (1885). Neste estudo, o autor classifica a obra do escritor francês como "literariamente insignificante" (BRUNO, 1885, p. 174 apud MARTINS, p. 149), refutando o plágio, uma vez que nele aparecem apenas "informes de qualquer dicionário geográfico" (BRUNO, 1885, p. 174 apud MARTINS, p. 149). Como já dissemos, Berrini também afastou as obras devido ao romance francês ser "recente demais para que Eça se tivesse apaixonado por ele" (BERRINI, 1992, p. 32). Não é nosso objetivo analisar comparativamente essas duas obras. No entanto, gostaríamos de destacar rapidamente textos que se dedicaram a tal tarefa. As mais representativas comparações, a nosso ver, foram feitas por Coimbra Martins, no referido "O Mandarim Assassinado" e, mais recentemente, por Beatriz Berrini (1992) e Carlos Jorge $(1999)^{90}$.

Coimbra Martins, concordando parcialmente com João de Meira, enxerga uma certa influência de Júlio Verne na narrativa queirosiana, na "voga parnasiana do 'Império das Flores' e gosto oitocentista pela narrativa aventurosa” (MARTINS, 1967, p. 151). Esta "voga parnasiana" citada por Coimbra Martins diz respeito a "estância ideal de arte, requinte, fantasia delicada e fino prazer" (MARTINS, 1967, p. 151), ou seja, uma imagem positiva e idealizada do império chinês. No entanto, o autor deste ensaio, ainda contrapõe a imagem negativa, a que chama de "verdadeira" China, que Teodoro terá do interior da China, lembrando do contato de Eça com os trabalhadores chineses em Havana. E conclui:

\footnotetext{
${ }^{90}$ Coimbra Martins ainda lembra de outros estudos dando destaque ao de João de Meira, em Influências Estrangeiras de Eça de Queirós (1902) como o primeiro texto onde se aplicou "criteriosamente o método comparativo à análise da obra do nosso romancista" (MARTINS, 1967, p. 149). Outros nomes lembrados são Antonio Cabral e Jean Girodon.
} 
Compreende-se, pois que Les Tribulation d'un Chinois en Chine tenham interessado o nosso romancista, cuja atenção juvenil teria sido atraída para uma China de miniatura parnasiana; e que, presumivelmente, se convencera, mais tarde, da 'barbaridade' do Celeste Império; que imaginara o valor estético da grande aventura, e sentira o cansaço real da viagem e do desconforto. O livro de Julio Verne, mostrando a China, desenvolvendo uma aventura focando a pobreza e os perigos do Império do Meio, caía como sopa no mel. Não era ele, além de tudo isso, uma mina de sugestões e notícias, infelizmente inexatas, mas perfeitamente concordantes com as virtualidades da fórmula do mandarim? (MARTINS, 1967, p. 152153)

Conforme dito anteriormente, Berrini afasta a possibilidade de Verne ser a inspiração de Eça, principalmente, por uma questão temporal. Porém, para corroborar tal ideia, a estudiosa traça "um paralelo com o livro de Julio Verne", mas "não sem antes ter em mente que inúmeras obras contemporâneas também apresentam descrições de acepipes chineses" (BERRINI, 1992, p. 32). Assim, compara as cenas dos jantares chineses presentes em ambas as obras, dialogando também com outros textos, franceses e ingleses, contemporâneos dos autores. Assim, atesta que "existem semelhanças, portanto, e também diferenças" (BERRINI, 1992, p. 33), concluindo que "Assim, para o seu almoço chinês, Eça de Queirós poderia ter colhido as informações de que necessitava em livros de vários outros autores, e não somente em Júlio Verne" (BERRINI, 1992, p. 33).

Carlos Jorge, em sua análise, adentra os textos, fazendo uma comparação das duas viagens à China. Não tratando um como influência ao outro, uma vez que nunca será possível saber se Eça conheceu o livro de Verne (JORGE, 1999, p.245), a questão central de seu artigo é "por que terão situado os romancistas grande parte das suas histórias no espaço da civilização chinesa?” (JORGE, p. 246, grifo do autor). Ao comparar a representação do espaço chinês, Carlos Jorge encontra um espaço de contrastes fortes (imagens positivas $\mathrm{x}$ imagens negativas), percebendo que essa construção se deve ao fato dessas representações contrastantes serem as que os autores 
recebiam de suas fontes. Diz: "Parece-nos ser essa bipolaridade real [...] porque dela apenas recebiam imagens caricaturais ou exóticas pelo acentuar das diferenças, que torna o espaço da civilização chinesa tão importante para os dois escritores" (JORGE, p. 256).

Outros estudos se dedicaram à análise do espaço chinês de $O$ Mandarim. Uma vez que ele contempla boa parte dessa novela queirosiana (do capítulo IV ao VII) é praticamente inviável fazer uma análise da obra sem perpassar, mesmo que rapidamente, pela China e sua construção.

De um modo geral, a crítica tem convergido a alguns pontos em comum em suas leituras da China. A primeira questão a ser lembrada é o fato de Eça nunca ter visitado essa região, questão que já tratamos, e, assim, ser montada a partir de referências externas. Ainda é sempre importante destacar que o narrador da história é o amanuense Teodoro, de quem trataremos mais detidamente adiante. Portanto, seria um equívoco ler as imagens vistas pelo narrador como uma visão direta do escritor ${ }^{91}$. Com tal fato, concordamos inteiramente. A China normalmente é lida como um espaço exótico e de sonho do narrador. Tal imagem é retirada a partir da própria carta que serviria como prefácio a edição francesa de $O$ Mandarim, em 1884, em que Eça diz: "Esta obra pertence ao sonho e não à realidade ${ }^{92 "}$ (QUEIRÓS, 1992a, p.197, tradução nossa). Tal interpretação podemos encontrar no artigo de Anna Kalewska quando diz: "reconhecese [...] em $O$ Mandarim e na carta-prefácio a obtusa atmosfera social e cultural da

\footnotetext{
${ }^{91}$ Beatriz Berrini aproxima as vozes de Eça e de Teodoro quando coteja as descrições da China de Les Tribulation d'un Chinois en Chine e $O$ Mandarim. Cito: "Existem semelhanças, portanto, e também diferenças. A maior, entre estas, reside nos comentários e apreciações de Eça-Teodoro. A menção ao autor não é fortuita: por detrás do narrador, adivinhamos a sombra do autor, apropriando-se do texto de certa forma, usando da personagem para tecer os seus comentários" (BERRINI, 1992, p. 33). No entanto, mais adiante, volta a separar o escritor da personagem: "A voz, porém, a expressar o juízo negativo sobre aquele recanto da China, não é a do autor: o responsável pelas impressões recebidas e pelo relato é o medíocre Teodoro" (BERRINI, 1992, p. 36). Assim, de acordo com a estudiosa, a voz de Eça se faz presente na maneira descritiva - "caracteristicamente queirosianas, além de [...] muito lusas" (BERRINI, 1992, p. 33) - e não nos julgamentos sobre a China em si.

92 "Cette oeuvre appartient au rêve et non a realitè" (no original).
} 
Regeneração conjugada com o sonho e a fantasia de um português no Extremo Oriente" (KALEWSKA, 2002, p. 383). Ellen W. Sapega corrobora tal imagem ao ler que "o Oriente não é visto, portanto como parte do mundo moderno; pelo contrário, pertence e sempre pertencerá à ordem do sonho colectivo ocidental” (SAPEGA, 2002, p. 449). Orlando Grossegesse vai mais longe afirmando que "embalado pelas "suaves sestas dos jardins de Pequim' o leitor pode ir esquecendo que a aventura de Teodoro é mero sonho seu de leitor, caindo, desse modo, no mesmo sonho" (GROSSEGESSE, 2000, p. 771). Tais interpretações se ligam, obviamente, ao caráter "fantasista e fantástica 93 " (QUEIRÓS, 1992a, p. 197, tradução nossa) ${ }^{94}$ da obra. Adiantamos que, em nosso estudo, não trabalharemos com o caráter fantástico e exótico de $O$ Mandarim. Embora sejam inegáveis e julguemos absolutamente plausíveis também tais leituras, acreditamos que Eça de Queirós não se limita em caracterizar o Oriente como o espaço exótico do imaginário europeu, discutindo questões mais profundas (e reais) das relações entre o Ocidente e o Oriente.

As leituras da China enquanto sonho, muitas vezes, aproximam essa narrativa da obra de Edward Said, como também fizemos em outros textos queirosianos, quando aquele diz do "devaneio coletivo sobre o Oriente" (SAID, 2008, p. 89). Ellen Sapega ainda usa-se de Said para ler o Oriente como um espaço que "representa o exacto oposto do mundo racionalista ocidental” (SAPEGA, 2002, p. 447), quando faz a análise do fato de o fantasma de Ti-Chin-Fú desaparecer quando Teodoro chega à China. Grossegesse usa-se de Said para embasar a leitura do Oriente de $O$ Mandarim como "menos um lugar real do que um topos, um leque de referências, provenientes de uma citação ou de um fragmento textual [...], de imaginações prévias ou de um amálgama de tudo isso"

\footnotetext{
93 "fantaisiste et fantastique" (no original).

${ }^{94}$ Para uma análise cuidadosa de $O$ Mandarim como um texto fantástico, conferir SEQUEIRA (2002, p. 383-449). Dalila Lara (2012), em sua dissertação de mestrado, também interpreta a China como espaço exótico e insólito, fazendo uma leitura de $O$ Mandarim às luzes das teorias da literatura fantástica.
} 
(GROSSEGESSE, 2000, p. 770), lendo assim, a novela de Eça como uma "escrita orientalista" $^{95}$ (GROSSEGESSE, 2000, p. 770). Monica Figueiredo, em seu artigo, lucidamente, esclarece que

nenhum de nós passou isento da obra de Edward Said, por isso, pensar na China "construída" pelo discurso queirosiano, significa de certa forma colocá-la frente às ideias defendidas pelo teórico que notabilizou a problematização das relações Ocidente-Oriente no século XX, utilizando o discurso literário como base para uma análise histórico-social. (FIGUEIREDO, 2005, p. 108)

No entanto, Monica Figueiredo se vale de Said, principalmente para embasar a visão negativa que Teodoro acaba por adquirir da China ao longo de sua estadia no Império do Meio. Também lembra que toda a visão de Teodoro é feita por um discurso orientalista, destacando a importância da linguagem na separação entre o Ocidente e o Oriente. Cito: "Edward Said aponta que é pelo discurso que o Ocidente estabeleceu o seu poder sobre o Oriente, pois pela linguagem fixou valores que definiram, para depois por, o que era nós e o que eram eles" (FIGUEIREDO, 2005, p. 120, grifo da autora).

A partir do uso das teorias saidianas e dos próprios trechos destacados até o momento, é possível perceber que um dos aspectos destacados por parte da crítica é a existência de "duas Chinas", isto é, duas imagens da China pelos olhos do Teodoro: uma positiva e outra negativa. Embora, alguns artigos privilegiem uma visão em detrimento a outra, dependendo do teor da análise feita, muito já se disse do contraste dessas visões antagônicas do Império do Meio.

O primeiro a trabalhar essas imagens opostas da China foi, mais uma vez, Coimbra Martins. Relembrando, o autor de "O Mandarim Assassinado" remete rapidamente a visão positiva de Teodoro à "voga parnasiana", em que a China foi

\footnotetext{
${ }^{95}$ Mais adiante, Grossegesse caracterizará $O$ Mandarim como uma "escrita orientalista em segundo grau" (GROSSEGESSE, 2000, p. 773). Para tal expressão, o autor explica: "Este espaço [China] é lido quase exclusivamente na sua forma exótica, com o objetivo de embelezar as projeções familiares, sendo incapaz de perceber os significados ocultos, porém, autênticos desse Oriente." (GROSSEGESSE, 2000, p. 773).
} 
"estância ideal de arte, requinte, fantasia delicada e fino prazer" (MARTINS, 1967, p. 151), ligando esta prática à juventude de Eça. Mas logo destaca a mudança de uma visão positiva para uma visão negativa, aproximando esta China negativa a sua experiência de cônsul em Havana. Cito:

O próprio Eça de Queirós, enquanto cônsul na Havana, observara a miséria dos emigrantes chineses. E, após ter viajado, a sua ânsia juvenil de viagens converteu-se em decepção. Assim [...] [a] atenção juvenil [de Eça] teria sido atraída por uma China de miniatura parnasiana; e que, presumivelmente, se convencera, mais tarde, da 'barbaridade' do Celeste Império (MARTINS, 1967, p. 152).

Berrini destaca a visão negativa de Teodoro acerca da China, um olhar tipicamente ocidental, incapaz de compreender o "outro":

Dessas narrativas, no geral, emerge uma impressão negativa, a denotar juízos preconceituosos, pois o Oriente era sempre visto a partir de e em paralelo com o Ocidente. Paira uma geral incompreensão do Outro $\mathrm{e}$, por isso mesmo, um certo gosto em alardear a miséria patente nos grandes centros, a quase absoluta falta de higiene (BERRINI, 1992, p. $35)$.

Concordante com a leitura de Coimbra Martins, também refere-se à experiência de Eça com a colônia chinesa em Havana como fundamental para a descrição negativa de Teodoro. Anteriormente a estudiosa já tinha se referido à imagem positiva da China como um eco da "voga parnasiana", também partindo do pensamento do autor de "O Mandarim Assassinado". No entanto, como ressaltamos, Berrini ainda destaca "os relatos dos viajantes, seduzidos pela cultura chinesa" (BERRINI, 1992, p. 34), aproximando essa imagem positiva à literatura de viagem e aos artigos em periódicos escritos na época, lembrando que "foi Eça de Queirós, sempre, um assíduo e sequioso leitor de periódicos e volumes" (BERRINI, 1992, p. 35).

Outras leituras caminham para interpretações semelhantes, porém destacando cada qual suas peculiaridades. Enfatizamos aqui os textos de Carlos Reis (2003), Carlos Jorge (1999), Ellen W. Sapega (2002) e Maria do Carmo Sequeira (2002). 
Carlos Reis enfatiza a China negativa vista por Teodoro. Em sua Introdução à edição de $O$ Mandarim da Editorial Presença, dialoga, em partes, com Berrini ao dizer: "não se se sabe bem se o retrato um tanto negativo que da China e dos Chineses é formulado se deve ao enfastiamento de Teodoro ou simplesmente à sua incapacidade de europeu para entender uma cultura e uma civilização que lhe são estranhas" (REIS, 2003, p. 19). Do aspecto positivo que a China pode configurar aos olhos de Teodoro, pondera apenas que

apesar dessa indiferença, o relato deste viajante entediado deixa perceber os vastos arrozais, os campos inundados, as aldeias miseráveis, os vestígios do Império, a arquitetura religiosa e sobre tudo a multitudinária, agitada e exótica Pequim, essa cidade de imensas dimensões físicas e humanas que a Teodoro suscita uma exclamação significativa: "Oh cidade fabulosa e singular". (REIS, 2003, p. 19).

Já Carlos Jorge, embora destaque que "as 'duas' Chinas estão presentes" (JORGE, 1999, p. 253), discorda da visão de Coimbra Martins.

Pelo que constatamos, não estamos de acordo, por exemplo, que tenha havido primeiro uma China de miniatura, requintada e mesmo 'teatral', no imaginário primeiro do romancista, e que depois tenha surgido uma mais 'real', resultante da experiência, do conhecimento do mundo e da leitura de Verne (JORGE, 1999, p. 253).

Sem se preocupar com supostas origens de tais imagens e destacando que, em Pequim, Teodoro encontra "os prazeres da civilização requintada", enquanto fora dela se veem "sinais de desordem, de anarquia e mesmo de selvajaria" (JORGE, 1999, p. 254), o autor salienta que o cenário "bipolar" evidencia "contrastes fortes, entre civilização e barbárie, ou mesmo entre civilização e selvajaria", tornando-se, assim, "aspecto fundamental para a construção da narrativa” (JORGE, 1999, p. 255). Assim, faz-se presente a relação da cidade de Pequim, centro do poder, com a ordem e do restante da China com a desordem. Cito: "Em Eça, o sublinhar dessa ordem central e organizadora [Pequim] surge, sobretudo pelo modo como ela se contrapõe com a 
desordem que, no horizonte, lhe surge sempre pelo aspecto do espaço ameaçador do deserto e das montanhas" (JORGE, 1999, p. 249).

Ellen W. Sapega discorda indiretamente de Coimbra Martins e Berrini ao não considerar a influência da experiência consular de Eça em Cuba como fundamental para a construção da China de $O$ Mandarim. Citando um trabalho de José Suarez ${ }^{96}$, diz:

José Suarez vai até ao ponto de interpretar o protagonista como símbolo daquilo que Eça não foi (ao optar por matar o Mandarim, Teodoro não hesita em explorar o chinês e, por extensão, também não hesitaria em aceitar os subornos que Eça rejeitava). Esta intepretação não me parece convincente, contudo, pelo facto de as descrições chinesas (tanto os nobres como os pobres e humildes) contidas no conto serem por demais estereotipadas, daí revelando uma certa falta de conhecimento e simpatia pela situação social chinesa. (SAPEGA, 2002, p. 446).

Mais adiante, embasada em Edward Said, dá-nos uma leitura nova das feições positivas e negativas que a China adquire aos olhos de Teodoro. É feita uma ligação histórica a cada representação, sendo a China antiga como um país glorioso e a China moderna um país decadente. Cito:

A sua impressão da China moderna é de um país decadente, com a cidade capital a lembrar-lhe Babel ou Nínive. Esta tendência de contrastar o passado glorioso do país com o seu presente pobre e confuso representa uma postura típica do viajante europeu na Ásia, pois como comenta Said, um dos projetos do orientalismo do século XIX era o de tratar o Oriente como 'something to be restored not only because of but also despite the modern Orient's disorderly and elusive presence $^{97}$ (SAPEGA, 2002, p. 447).

Por fim, Maria do Carmo Sequeira (2002), dialogando indiretamente com Orlando Grossegesse (2000), destaca a China como um espaço familiar a Teodoro, vista a partir de suas leituras e de um mobiliário. Diz: "uma paisagem igualmente sugestiva [...] se aproxima, apesar de tudo, familiarmente [...] através das marcas pictóricas reconhecidas da porcelana chinesa" (SEQUEIRA, 2002, p. 429). Assim, “esta paisagem

\footnotetext{
${ }^{96}$ A referência dada a este estudo é: SUAREZ, José. "Cuba y El Mandrín de Eça de Queiroz". Círculo: Revista de Cultura 12 (1983): 51-57.

97 "Alguma coisa a ser restaurada não apenas, mas também, por causa da desordenada e elusiva presença do Oriente moderno" (tradução nossa).
} 
desdobra-se [...] noutros lugares comuns do exotismo chinês, criando sempre uma atmosfera reconhecível" (SEQUEIRA, 2002, p. 429). Grossegesse havia destacado que “a paisagem logo lhe é familiar por assemelhar-se 'à dos vasos de porcelana, de um tom azulado vaporoso': a leitura inicial da China faz-se significativamente à base do mobiliário chinois, em obediência à moda europeia orientalista” (GROSSEGESSE, 2000, p. 771). Opondo os "aspectos contrastantemente marcados ou pelo horror ou por um colorido exorbitante e rico" (SEQUEIRA, 2002, p. 430), a estudiosa do fantástico na obra queirosiana conclui que

sob um véu irônico e hiperbolizado, vai surgindo implicitamente um quadro de costumes, onde, através da excentricidade das cores e dos movimentos, aparecem os pormenores mais densamente fabulosos da ficção do "outro" (SEQUEIRA, 2002, p. 431).

Muitos dos estudiosos de $O$ Mandarim costumam destacar, independentemente do enfoque positivo, negativo ou contrastante da visão do narrador, uma vez que nunca foi visitada por Eça e por ser Teodoro a "figuração exemplar do europeu, incapaz de entender as civilizações orientais" (GROSSEGESSE, 2000, p. 772), ou por vezes, o "típico viajante europeu na Ásia” (SAPEGA, 2002, p. 445), a China como "uma China ficcional.” (BERRINI, 1993, p. 200). Esta leitura, obviamente, vai ao encontro da visão da China como um lugar do sonho, leitura anteriormente destacada. Aqui realçamos apenas a ênfase dada pelos críticos a essa ficcionalidade chinesa. Jorge destaca a visão chinesa pelos olhos do protagonista como "artificial" (JORGE, 1999, p. 255) e conclui que "A China assim desenhada não pretende ser a verdadeira China" (JORGE, 1999, p. 256). Grossegesse enfatiza que a China para Teodoro "reduz-se, portanto, a uma forma decorativa" (GROSSEGESSE, 2000, p. 772). Maria do Carmo Sequeira destaca que "a viagem à China, torna-se assim, uma espécie de apanhado de clichês” (SEQUEIRA, 2002, p. 433). Carlos Reis defende que a “China n'O Mandarim é uma descrição inevitavelmente subjectiva [...]. É Teodoro o narrador da história e é pelo filtro do seu 
(ficcional) poder de observação e de avaliação que colhemos uma ainda assim relativamente pormenorizada imagem da China" (REIS, 2003, p. 19). E, por fim, Berrini ainda completa que “a imagem da China que o autor constrói n'O Mandarim é também algo caricatural e malévola". (BERRINI, 1992, p. 31).

Uma vez que existe o consenso que a China construída por Eça é uma China vista pelos olhos de Teodoro, e com tal, já dissemos, concordamos, é preciso que passemos rapidamente pelas visões da crítica sobre a figura do amanuense lisboeta. Muitas dessas leituras já foram destacadas por nós ao longo do texto. Ressaltamos a figura de Teodoro enquanto "personagem-tipo" (LARA, 2012, p. 57), ou seja, o "exemplar do europeu, incapaz de entender as civilizações orientais" (GROSSEGESSE, 2000, p. 772), “típico viajante europeu na Ásia” (SAPEGA, 2002, p. 445) e como homem que "emblematiza a visão oitocentista que tem o europeu comum a respeito da China" (FIGUEIREDO, 2005, p. 113) No entanto, Teodoro se faz uma personagem tão plural quanto toda a novela de Eça. Isso permite com que leituras, muitas vezes distintas, possam ser feitas sem que uma seja menos valiosa, interessante ou que uma esteja mais correta que a outra. Em outras palavras, Teodoro enquanto narrador e personagem de sua própria história ${ }^{98}$ tem muito a nos dizer de diversos temas que rondavam Portugal e o mundo do final do século XIX, fazendo com que seu olhar possa ser apontado a inúmeras direções.

Para ilustrar a multiplicidade de leituras do assassino de Ti-Chin-Fú, recorremos aos estudos Ana Paula Foloni Gamba (2005), de Sérgio Nazar David (2007) e David G. Frier (2010).

Ana Paula Gamba, em sua dissertação de mestrado que analisa $O$ Mandarim sob a ótica da sátira menipéia destacando, assim, o humor e a crítica à sociedade portuguesa

\footnotetext{
${ }^{98}$ Para um estudo detalhado da diferenciação de Teodoro narrador e Teodoro personagem, conferir o capítulo "Autodiegese: O Mandarim e A Relíquia" em Estatuto e Perspectivas do Narrador na Ficção de Eça de Queirós de Carlos Reis (1984, p. 179-210).
} 
do século XIX, discute a possibilidade da existência de três faces de Teodoro: "o amanuense ambicioso, porém, conformado, o homem inescrupuloso, capaz de tudo para alcançar seus objetivos, e aquele Teodoro Renovado, em que se revelou a possibilidade de um outro homem e de uma outra vida”. (GAMBA, 2005, p. 73).

Sérgio Nazar David, em “Duas faces da Renúncia em O Mandarim” presente em seu livro O Século de Silvestre da Silva - Estudos Queirosianos, traz uma leitura psicanalítica do homem, representado por Teodoro. Destaca, à luz da teoria freudiana, a procura de Teodoro pelo gozo e, não obtendo êxito, sua eterna posição de vítima perante a sociedade. David mostra que independentemente do poderio financeiro (ou seja, tanto quando era pobre como quando fica rico; mesmo quando vai à China à procura da família do mandarim, como quando, resignado, volta a Portugal), Teodoro sempre “reservará para si o papel de vítima" (DAVID, 2007, p. 69), entregando aos outros a culpa de sua infelicidade. Diz o autor que Teodoro "não reconhece algo de seu nos atos que pratica e nas escolhas que faz" (DAVID, 2007, p. 80), concluindo que "o homem se torna vítima da sociedade e da Consciência. Mas, na verdade, ele é vítima da posição que assume diante da vida". (DAVID, 2007, p. 80).

Leitura diferente, porém não oposta, será feita por David G. Frier em artigo publicado no periódico Luso-Brazilian Review. Seu estudo faz uma análise de $O$ Mandarim como uma autoimagem de Portugal do final do século XIX, evidenciando Teodoro como símbolo desse Portugal finissecular. Assim, são destacados os pensamentos capitalista e colonialista da Europa da época. Evidencia o apego de Teodoro ao dinheiro (símbolo de um Portugal materialista) que enxerga como seu, mesmo quando vai à China. Afinal, diz o autor, "sua identidade reside apenas no dinheiro e no poder que [este dinheiro] lhe empresta ${ }^{99 "}$ (FRIER, 2010, p. 152, tradução

\footnotetext{
99 "his very identity lies only in money and the power which it lends him" (no original).
} 
nossa). Adiante discute como o não entendimento da impossibilidade de casamento com a viúva de Ti-Chin-Fú serve como metáfora de um Portugal que, ainda apegado a seu passado glorioso da época das Grandes Navegações, não soube encaixar-se no cenário europeu do fim do século XIX, não reconhecendo "a realidade da relativa fraqueza da economia portuguesa em comparação com o aumento dos poderes do norte da Europa e da América do Norte ${ }^{100 \%}$ (FRIER, 2010, p. 160, tradução nossa). Assim, Frier analisa Teodoro mais do que um mero viajante europeu oitocentista, mas como símbolo político e econômico de seu próprio país.

Sumariamente, pudemos perceber que a crítica, de um modo geral, tende a interpretar $O$ Mandarim como um texto que se encaixa perfeitamente no "Orientalism framework $101 "$ (FRIER, 2010, p. 158). Um texto que "tem muito mais a ver com os debates europeus contemporâneos sobre a China [...] do que com a complexa e concreta realidade humana ou social do povo chinês" (SAPEGA, 2002, p. 446), "uma leitura crítica do orientalismo" (GROSSEGESSE, 2000, p. 773), sendo também uma paródia do discurso orientalista. (GROSSEGESSE, 2000, p. 774)

O que parece ser unânime na crítica, independentemente do enfoque dado por cada pesquisador em sua análise, é a forte presença da ironia, questão tão recorrente nos estudos das obras queirosianas. A ironia se apresenta na visão limitada de Teodoro, "o típico viajante europeu do século XIX" (SAPEGA, 2002, p. 445), na construção da China, em seu pensamento e em tantos outros aspectos que aparecem da primeira à última linha da novela. Portanto, $O$ Mandarim é mais um grande exemplo da fina ironia queirosiana. E, acrescentamos, nunca podemos deixar de ter isso em mente ao lermos a história da vida de Teodoro.

\footnotetext{
100 "the reality of the relative weakness of the Portuguese economy in comparison to the rising powers of northern Europe and North America" (no original).

101 "Quadro do Orientalismo" (tradução nossa).
} 
Não poderíamos encerrar nosso percurso sobre as principais ideias expostas nos estudos acerca d' $O$ Mandarim sem destacarmos leituras que relativizam a clássica visão fantástica desta novela queirosiana. O Mandarim, uma vez que, de acordo com o próprio Eça em sua carta-prefácio, difere dos ideais realista-naturalista presentes em $O$ Crime do Padre Amaro e $O$ Primo Basílio, pode ser lido como um ponto de interrogação no projeto literário ${ }^{102}$ do nosso autor ${ }^{103}$. No entanto, existem estudos que destacam o caráter realista desta novela ${ }^{104}$. Separamos dois textos que julgamos ser mais representativos: a análise de Monica Figueiredo (2005) e o estudo de Sérgio Nazar David (2007).

Monica Figueiredo lembra que "se politicamente a literatura realista pretendeu ser um retrato da realidade, esteticamente não o conseguiu, e foi graças à sua ‘incapacidade fotográfica' que a[s] obra[s] de um Flaubert, de um Zola e de um Eça de Queirós permaneceram na memória cultural do Ocidente, vencendo a perecibilidade da função documental” (FIGUEIREDO, 2005, p. 108). Assim, “a (re)apresentação do real só é possível através da linguagem, no entanto, o que ela (re)cria não é o real da coisa [...] mas sim o efeito de real" (FIGUEIREDO, p. 109, grifo da autora). Passando a analisar Eça de Queirós e seu $O$ Mandarim, diz:

Eça de Queirós, como poucos, conseguiu um preciso "efeito de real" ao percorrer o contorno dos corpos, o desenho das casa, a geografia das cidades portuguesas e as paisagens do mundo oitocentista. Assim, no lugar de "fantasia" [...], prefiro entender $O$ Mandarim como uma grande alegoria, ou menos como uma "ficção que representa uma

\footnotetext{
${ }^{102}$ Como projeto literário nos referimos a pretensão de Eça de escrever "uma coleção de pequenos romances [...] que fosse a pintura da vida contemporânea em Portugal" (QUEIRÓS, 2000a, vol. 4, p. 824). A tal coleção se daria o nome de Cenas da Vida Portuguesa, conforme nos diz o autor em carta de cinco de outubro de 1877 a seu editor Ernesto Chardron.

${ }^{103}$ Orlando Grossegesse (2000, p. 769) discute esse "ponto de interrogação" na carreira literária de Eça aproximando $O$ Mandarim e A Relíquia das primeiras obras de Eça, servindo como uma retomada dos temas do escritor nos anos de 1869-70.

${ }^{104}$ É importante ressaltarmos que características realistas do autor, principalmente nas construções e descrições do espaço de $O$ Mandarim, são destacadas por diversos estudos. No entanto, normalmente lêse como um texto com "um certo equilíbrio" (REIS, 2003, p. 17) entre o real e o fantástico ou uma "mescla de realidade e fantasia" (GAMBA, 2005, p. 64). Os estudos que destacamos aqui, diferentemente, não leem $O$ Mandarim como um texto fantástico.
} 
coisa para dar ideia de outra", como sabiamente nos ensina o velho e bom dicionário. (FIGUEIREDO, 2005, p. 109).

A partir de então, desenvolve sua leitura (relacionando a experiência de Eça com a colônia chinesa em Cuba; leitura do orientalismo saidiano; questões imperialistas; Teodoro e o passado colonizador de Portugal; entre outros tópicos) em que se destacam alguns aspectos acima assinalados, concluindo que "muito pouco neste conto pode ser chamado de fantasia" (FIGUEIREDO, 2005, p. 120).

Uma leitura em que muito há de realismo na novela é feita também por Sérgio Nazar David, que, através da sua análise da personagem Teodoro enquanto vítima, apoiada, principalmente, no pensamento de Freud, conforme destacamos anteriormente, diz: "O Mandarim pode ser lido como o realismo levado às últimas temperaturas porque Eça termina por representar Teodoro e o próprio leitor como vítimas da Humanidade e de forças interiores poderosas contra as quais pouco podem fazer" (DAVID, 2007, p. 78). Vale ressaltar, ainda, que David, neste estudo, dá uma interessante contribuição para o fortalecimento das peculiaridades dadas por Eça ao paradoxo do mandarim em seu texto. Afastando o autor de Os Maias de seus antecessores franceses, David diz:

Para Eça realista, diferentemente de Rousseau e de Chateaubriand que apostam na força dos imperativos da razão que resultam de uma Consciência presidida por Deus ${ }^{105}$ - o que é categórico é o gozo. A Humanidade diz-nos: "és um verme". O supereu completa: "goza e dá-te por satisfeito" (DAVID, 2007, p. 78).

Com todas essas questões expostas, podemos passar a nossa análise da novela. Antes, no entanto, vale lembrarmos que, obviamente, não esgotamos todos os assuntos tratados nas análises consultadas. Nem era esse nosso objetivo. Destacamos apenas alguns aspectos que julgamos importantes para a compreensão da pluralidade que esse texto pode ter, além de um entendimento maior da questão da China, e, portanto, do

\footnotetext{
${ }^{105}$ Em momento anterior do estudo, David já dissera: "Em Rousseau e em Chateaubriand, não há a situação objetiva. Há o dilema: matar ou não matar o chinês! E há a solução do dilema. Rousseau e Chateaubriand dissolvem-no sob o imperativo categórico: não! não matarás!" (DAVID, 2007, p. 51).
} 
Extremo Oriente na obra queirosiana. Ressaltamos ainda que, uma vez que o texto é bastante complexo e permite inúmeras interpretações, nem tudo do que foi exposto representa nosso pensamento. Entretanto, muitos dos aspectos que foram ditos por nossos antecessores servirão como pressupostos para nossa análise. Assim, remontaremos algumas ideias já expostas aqui agregando a elas nossa interpretação.

\subsubsection{AS REPRESENTAÇÕES DA CHINA EM O MANDARIM E O (NÃO) DIÁLOGO ENTRE OCIDENTE E ORIENTE.}

As representações do Extremo Oriente em $O$ Mandarim se iniciam muito antes de Teodoro, amanuense lisboeta de vida simples, porém monótona, viajar à China. A primeira passagem que apresenta uma referência ao Império do Meio se dá ainda no primeiro capítulo, momentos antes da aparição do Diabo ${ }^{106}$, "tão contemporâneo, tão regular, tão classe média como se viesse da minha repartição...” (QUEIRÓS, 1992a, p. 89). Teodoro compra na feira da Ladra um “desses in-fólios vetustos” (QUEIRÓS, 1992a, p. 85) onde lê o paradoxo do mandarim:

Uma noite, há anos, eu começara a ler, num desses in-fólios vetustos, um capítulo intitulado Brecha das Almas; e ia caindo numa sonolência grata, quando este período singular se me destacou do tom neutro e apagado da página, com o relevo de uma medalha de ouro nova brilhando sobre um tapete escuro: copio textualmente:

"No fundo da China existe um Mandarim mais rico que todos os reis de que a Fábula ou a História contam. Dele nada conheces, nem o nome, nem o semblante, nem a seda de que se veste. Para que tu herdes os seus cabedais infindáveis, basta que toques essa campainha, posta a teu lado, sobre um livro. Ele soltará apenas um suspiro, nesses confins da Mongólia. Será então um cadáver: e tu verás a teus pés mais ouro do que pode sonhar a ambição de um avaro. Tu, que me lês e és um homem mortal, tocarás tu a campainha?" (QUEIRÓS, 1992a, p. 85).

\footnotetext{
${ }^{106}$ Para um estudo cuidadoso sobre o Diabo de $O$ Mandarim, cf. NERY, 2010, p. 155-187.
} 
Perturbado com a capciosa pergunta "tocarás tu a campainha?" e sem conseguir ler mais o in-fólio "que parecia exalar magia” (QUEIRÓS, 1992a, p. 85), passa aos poucos a ter duas visões, como em um sonho acordado:

de um lado um Mandarim decrépito, morrendo sem dor, longe, num quiosque chinês, a um ti-li-tim de campainha; do outro toda uma montanha de ouro cintilando aos meus pés! Isso era tão nítido, que eu via os olhos oblíquos do velho personagem embaciarem-se, como cobres de uma ténue camada de pó; e sentia o fino tinir de libras rolando juntas (QUEIRÓS, 1992a, p. 86).

A primeira imagem formada por Teodoro é a de um chinês decrépito. No texto presente em "Brechas das Almas" nada diz sobre o chinês. Pelo contrário, lá é dito que "dele nada conheces". No entanto, em sua imaginação, Teodoro o desenha como decrépito. Já não deixa de ser uma visão caricata e redutora do funcionário da repartição criada a partir de conhecimento nenhum ou, no máximo, de um imaginário comum. Mesmo antes da aparição do Diabo e sua persuasão, a imagem formada acerca do mandarim já é uma visão que tende a diminuir a importância da figura chinês e, assim, legitimar, ou, em palavras mais suaves, tirar o peso do ato criminoso que Teodoro, naquele momento, ainda não cometera.

No meio das visões de Teodoro aparece o Diabo, com "uma voz insinuante e metálica” (QUEIRÓS, 1992a, p. 89) e diz: “- Vamos Teodoro, meu amigo, estenda a mão, toque a campainha, seja um forte!” (QUEIRÓS, 1992a, p. 89). Tenta este, então, convencer o amanuense a tocar a campainha e fala dos prazeres que poderá ter com a fortuna do desconhecido chinês. Ainda não convencido, o Diabo diz:

- Que me diz a cento e cinco, ou cento e seis mil contos? Bem sei, é uma bagatela... Mas enfim, constituem um começo; são uma ligeira habilitação para conquistar a felicidade. Agora pondere estes factos: o Mandarim, esse Mandarim do fundo da China, está decrépito e está gotoso: como homem, como funcionário do celeste império, é mais inútil em Pequim e na humanidade, que um seixo na boca de um cão esfomeado. (QUEIRÓS, 1992a, p. 93) 
Para convencer Teodoro, é preciso rebaixar o chinês, confirmar a imagem que Teodoro já criara em sua mente, imagem esta, insistimos, formada a partir de um imaginário coletivo. Sérgio Nazar David, ao analisar o mesmo trecho, diz:

O Diabo não se insurge contra as leis sociais. Mas ele quer impor a sua lei. Para isso, como sabe a quem está falando, precisa dizer que o crime, além de ser para o bem de Teodoro, não é um mal para o Mandarim. Teodoro deve tocar a campainha porque o Mandarim sofre de gota, não tem herdeiros, etc. O Diabo tem de minimizar a extensão do ato de Teodoro: diminui a importância do chinês e o mantém a distância. (DAVID, 2007, p. 56, grifo nosso)

Parece-nos inevitável, assim como nossos antecessores, aproximar tal imagem às teorias saidianas. Afinal, o que Teodoro e o Diabo fazem não deixa de se encaixar no “Orientalism framework" (FRIER, 2010, p.158) de Said. Ou seja, Teodoro cria (e o Diabo ratifica) uma imagem redutora, decadente de sua vítima para poder legitimar sua ação. Não foram essas as argumentações muitas vezes dadas pelas nações imperialistas para justificar suas “ações civilizadoras”?

Cometido o crime e tendo o Diabo partido, Teodoro se deita e sonha "que estava longe, para além de Pequim, nas fronteiras da Tartária, no quiosque de um convento de Lamas, ouvindo máximas prudentes e suaves que escorriam com um aroma fino de chá, dos lábios de um Buda vivo" (QUEIRÓS, 1992a, p, 99). A imagem aqui é outra. Agora predomina uma China mágica, com elementos budistas, uma China mais próxima da "voga parnasiana" destacada por Coimbra Martins. Vale destacar que isto é um sonho, como se Eça já nos quisesse destacar: nós, europeus, enxergamos assim. Mas isto, é pura imaginação nossa.

Portanto, logo no primeiro capítulo, muito antes de transportar seu protagonista ao "Império Florido", Eça já nos apresenta as duas imagens europeias do Oriente, mostrando que nem uma nem outra são baseadas em qualquer conhecimento ou contato, sendo tudo moldado de acordo com o que melhor convier. É tudo sonho, é tudo imaginação, é tudo criação. 
Acabamos de destacar a similaridade da concepção da imagem do mandarim com a teoria orientalista de Said, que discute a criação do estereótipo do oriental pelas nações europeias para justificar as políticas colonialistas e imperialistas. Pois não será diferente a forma como Teodoro adquire seu dinheiro. Um mês após a aparição do Diabo e o toque da campainha, Teodoro recebe uma visita. Reproduzo o trecho:

- São notícias para Vossa Senhoria! Consideráveis notícias! O meu nome é Silvestre... Silvestre, Juliano \& $C^{a} \ldots$... Um serviçal criado de Vossa Excelência... Chegaram justamente pelo paquete de Southampton... Nós somos correspondentes de Brito, Alves \& $\mathrm{C}^{\mathrm{a}}$, de Macau... Correspondentes de Craig and $\mathrm{C}^{\mathrm{a}}$, de Hong-Kong... As letras vêm de Hong-Kong...

O sujeito engasgava-se; e a sua mão gordinha agitava em tremuras um envelope repleto, com um selo de lacre negro.

- Vossa Excelência - prosseguiu - estava decerto prevenido... Nós é que o não estávamos... A atrapalhação é natural... O que esperamos é que Vossa Excelência nos conserve a sua benevolência... Nós sempre respeitámos muito o carácter de Vossa Excelência... Vossa Excelência é nesta terra uma flor de virtude, e espelho de bons! Aqui estão os primeiros saques sobre Bhering and Brothers, de Londres... Letras a trinta dias sobre Rothschild...

A este nome, ressoante como o mesmo ouro, saltei vorazmente do leito:

- O que é isso, senhor? - gritei.

E ele, gritando mais, brandindo o envelope, todo alçado no bico dos botins:

- São cento e seis mil contos, senhor! Cento e seis mil contos sobre Londres, Paris, Hamburgo e Amsterdão, sacados a seu favor, excelentíssimo senhor!... A seu favor, excelentíssimo senhor! Pelas casas de Hong-Kong, de Xangai e de Cantão, da herança depositada do mandarim Ti-Chin-Fú! (QUEIRÓS, 1992a, p. 103).

Eça poderia ter feito o dinheiro aparecer de maneira mágica para Teodoro. No

entanto, dá uma origem bastante capitalista à fortuna do amanuense. Frier destaca: “em um nível literal, sua riqueza é derivada não de algum fantástico esquema diabólico, mas do exercício do clássico neo-imperialismo capitalista, em que o valor excedente é extraído por investidores na Europa a partir do trabalho feito em seu nome por distante trabalhadores sem rostos (neste caso, na China [...]) ${ }^{107 ”}$ (FRIER, 2010, p. 153-154, tradução nossa). Mais uma vez, Eça desnuda a política europeia de seu tempo.

\footnotetext{
107 "at a literal level his wealth is derived not from some fantastic diabolical scheme but from the exercise
} of classical capitalist neo-imperialism, where surplus value is extracted by investors in Europe on the 
No terceiro capítulo, uma China imaginária é novamente desenhada pela mente de Teodoro. Após entrar para a alta sociedade lisboeta e começar a ser perseguido pela imagem do mandarim (que corresponde à imagem inicial criada por ele próprio), Teodoro relata:

\begin{abstract}
Depois assaltou-me uma amargura maior: comecei a pensar que TiChin-Fú tinha decerto uma vasta família, netos, bisnetos tenros, que, despojados da herança que eu comia à farta em pratos de Sèvres, numa pompa de sultão perdulário, iam atravessando na China todos os infernos tradicionais da miséria humana - os dias sem arroz, o corpo sem agasalho, a esmola recusada, a rua lamacenta por morada...

Compreendi então porque me perseguia a figura obesa do velho letrado; e dos seus lábios recobertos pelos longos pêlos brancos do seu bigode de sombra, parecia-me sair agora esta acusação desolada: "Eu não me lamento a mim, forma meio morta que era; choro os tristes que arruinaste, e que a estas horas, quando tu vens do seio fresco das tuas amorosas, gemem de fome, regelam na frialdade, apinhados num grupo expirante, entre leprosos e ladrões, na Ponte dos Mendigos, ao pé dos terraços do Templo do Céu!"' (QUEIRÓS, 1992a, p. 121).
\end{abstract}

Mais uma vez, sua mente cria uma imagem em que Teodoro deduz o que lhe é dito pelo mandarim. O estado "meio morto" do chinês, sua descendência "atravessando na China todos os infernos tradicionais da miséria humana" são criações de Teodoro que "não consegue ver que os chineses poderiam, talvez, sobreviver sem os envolvimentos desse intruso estrangeiro ${ }^{108 "}$ (FRIER, 2010, p. 156, tradução nossa). Tentando encontrar algo acerca do falecimento do mandarim Ti-Chin-Fú, Teodoro, finalmente, busca informações sobre a China:

li todos os jornais de Hong-Kong e de Xangai, velei a noite sobre histórias de viagens, consultei sábios missionários: - e artigos, homens, livros, tudo me falava da decadência do Império do Meio, províncias arruinadas, cidades moribundas, plebes esfomeadas, pestes e rebeliões, templos aluindo-se, leis perdendo a autoridade, a decomposição de um mundo, como uma nau encalhada que a vaga desfaz tábua a tábua!... (QUEIRÓS, 1992a, p. 127)

Deste trecho, podemos interpretar dois aspectos: o primeiro é que a partir do contato com textos, pessoas e outras fontes de informações, Teodoro tem, por fim, uma

basis of labour carried out on their behalf by faceless, distant workers (in this case in China [...])" (no original).

108 "cannot see that the Chinese could perhaps survive without the involvement of this foreign interloper at all" (no original). 
base na qual cria uma imagem da China. Imagem esta, bastante negativa, que irá se corroborar com a experiência da viagem, como veremos. Assim, quando parte ao Império do Meio, vai com ideias formadas (SAPEGA, 2002, p. 446). Essas ideias construídas, e aí está o segundo elemento a ser interpretado do trecho, a partir, mais uma vez, da imagem europeia em relação ao Oriente. Embora tenha consultado jornais de Hong Kong e Xangai, sabe-se que Teodoro de língua chinesa só conhece as palavras "chá" e "mandarim", a descobrir posteriormente que "Mandarim' [...] não é uma palavra chinesa, e ninguém a entende na China.” (QUEIRÓS, 1992a, p. 135). Portanto, seu contato, deduz-se, é com periódicos, provavelmente, ingleses e franceses. Logo, mais uma vez o discurso pautado na visão europeia se faz presente no texto queirosiano. Deste modo, Teodoro forma, ou melhor, compra ideias antes de ir diretamente à China. Ideais estas baseadas no eurocentrismo, portanto, ideias parciais.

Teodoro, então, tenta apagar a imagem do mandarim que lhe surge a todo o momento, mas, falhando em suas tentativas, tem "um plano formidável":

Partiria para Pequim; descobriria a família de Ti-Chin-Fú; esposando uma das senhoras, legitimaria a posse dos meus milhões; daria àquela casa letrada a antiga prosperidade; celebraria funerais pomposos ao Mandarim, para lhe acalmar o espírito irritado; iria pelas províncias miseráveis fazendo colossais distribuições de arroz; e, obtendo do imperador o botão de cristal de mandarim, acesso fácil a um bacharel, substituir-me-ia à personalidade desaparecida de Ti-Chin-Fú - e poderia assim restituir legalmente à sua pátria, se não a autoridade do seu saber, ao menos a força do seu oiro. (QUEIRÓS, 1992a, p. 129).

A viagem à China se inicia no capítulo IV e se estende até o capítulo VII, o penúltimo. É durante a estada de Teodoro na China que Eça lança

a sua crítica ferina sobre problemas como a corrupção existente na esfera política de um país, contraste entre a atual decadência de Portugal e o seu passado de glórias, o oportunismo do homem que busca tirar proveito próprio de todo tipo de situação, e toda uma sorte de mazelas humanas como a ganância, a cobiça e o adultério. (GAMBA, 2005, p. 62). 
O percurso de Lisboa a Pequim é descrito de maneira esquemática. Apenas informações rápidas de nomes de lugares, apontando o trajeto de Teodoro até a capital do império chinês.

Como procuramos ressaltar no item anterior, a crítica já destacou por diversas vezes o contato superficial que Teodoro tem com a China. A principal prova está no fato de, na China, Teodoro se hospedar na embaixada russa ${ }^{109}$ onde vive com o general Camilloff ${ }^{110}$ e sua esposa (que se torna amante de Teodoro), a generala Vladimira.

A vida de Teodoro fechada na embaixada russa nos lembra algumas palavras que Eça escreve em seu artigo "Chineses e Japoneses", catorze anos após a elaboração de $O$ Mandarim. Lá diz: “formando o pessoal das legações, não penetram na sociedade chinesa, vivem enclausurados dentro dos muros das 'Residências', [...] e só se familiarizam com os aspectos externos, ruas, lojas, frontarias de templos e perpassar das multidões" (QUEIRÓS, 2002, p. 532). Pois é este tipo de residente estrangeiro que Teodoro se torna em Pequim.

Resolve, então, conhecer a cidade acompanhado de seu guia, Sá-Tó, única personagem oriental do livro que, assim como vimos em O Mistério da Estrada de Sintra, também se encontra em posição subalterna do "colonizador" europeu. Pequim, de acordo com Teodoro, é dividida entre a cidade Tártara e a cidade Chinesa. O agora ex-amanuense resolve conhecer ambas, momento em que as "duas Chinas" se mostram presentes. A Cidade Tártara, primeira a ser visitada, é vista da seguinte maneira:

A habitação de Camilloff ficava na Cidade Tártara, nos bairros militares e nobres. Há aqui uma tranquilidade austera. As ruas assemelham-se a largos caminhos de aldeia sulcados pelas rodas dos

\footnotetext{
${ }^{109}$ Aqui, podemos conjeturar que a escolha da embaixada russa como lar de Teodoro na China não foi por acaso. A Rússia, geograficamente, é a principal ligação entre a Europa e a Ásia. Na novela também a delegação russa aparece como "ponte" entre Teodoro e a China.

${ }^{110}$ Dois estudiosos especulam a origem do nome dado por Eça ao general russo. João Medina em seu artigo onde expõe a infidelidade da tradução francesa do texto de Eça, diz: "haverá aqui uma discreta alusão ao romancista de Amor de Perdição, com o nome russificado?” (MEDINA, 1980, p. 119). Já Orlando Grossegesse destaca que este nome é "provável lembrança de uma leitura de Michel Strogoff, de Jules Verne" (GROSSEGESSE, 2000, p. 771).
} 
carros; e quase sempre se caminha ao comprido de um muro, donde saem ramos horizontais de sicômoros.

Por vezes uma carreta passa rapidamente, ao trote de um pónei mongol, com altas rodas cravejadas de pregos dourados; tudo nela oscila: o toldo, as cortinas pendentes de seda, os ramos de plumas aos ângulos; e dentro entrevê-se alguma linda dama chinesa, coberta de brocados claros, a cabeça toda cheia de flores, fazendo girar nos pulsos dois aros de prata, com um ar de tédio cerimonioso. [...] A cada momento parávamos a olhar as lojas ricas, com as suas tabuletas verticais de letras douradas sobre fundo escarlate: os fregueses, num silêncio de igreja, subtis como sombras, vão examinando as preciosidades - porcelanas da Dinastia Ming, bronzes, esmaltes, marfins, sedas, armas marchetadas, os leques maravilhosos de SwaTon: por vezes, uma fresca rapariga de olho oblíquo, túnica azul, e papoulas de papel nas tranças, desdobra algum raro brocado diante de um grosso chinês que o contempla beatamente, com os dedos cruzados na pança: ao fundo o mercador, aparatoso e imóvel, escreve com um pincel sobre longas tabuinhas de sândalo: e um perfume adocicado, que sai das coisas, perturba e entristece...

Eis aqui a muralha que cerca a Cidade Interdita, morada santa do imperador! Moços nobres vêm descendo do terraço de um templo onde se estiveram adestrando à frecha. Sá-Tó disse-me os seus nomes: eram da guarda selecta, que nas cerimónias escolta o guarda-sol de seda amarela, com o dragão bordado, que é o emblema sagrado do imperador. Todos eles cumprimentaram profundamente um velho que ia passando, de barbas venerandas, com o casabeque amarelo que é o privilégio do ancião; vinha falando só, e trazia na mão uma vara sobre que pousavam cotovias domesticadas... Era um príncipe do Império. (QUEIRÓS, 1992a, p. 143-145)

A descrição reflete o "ideal de arte, requinte, fantasia delicada e fino prazer" (MARTINS, 1967, p.151) que citamos anteriormente. A Cidade Tártara é traçada através de aspectos positivos que vêm ao encontro do imaginário europeu, em que impera a serenidade, os cerimoniais, a obediência e as tradições. Assim será também dentro da embaixada russa. Todos os contatos com a China se darão "de maneira decorativa” (GROSSEGESSE, 2000, p. 772), transmitindo uma atmosfera edênica. É na embaixada russa que Teodoro tem um jantar chinês (que embasou também a acusação de plágio):

Que gentis guardanapos de papel de seda escarlate, com monstros fabulosos desenhados a negro! O serviço começou por ostras de NingPó. Exímias! Absorvi duas dúzias com um intenso regalo chinês. Depois vieram deliciosas febras de barbatana de tubarão, olhos de carneiro com picado de alho, um prato de nenúfares em calda de açúcar, laranjas de Cantão, e enfim o arroz sacramental, o arroz dos Avós... 
Delicado repasto, regado largamente de excelente vinho de ChãoChigne! E, por fim, com que gozo recebi a minha taça de água a ferver, onde deitei uma pitada de folhas de chá imperial, da primeira colheita de Março, colheita única, que é celebrada com um rito santo pelas mãos puras de virgens!...

Duas cantadeiras entraram, enquanto nós fumávamos; e muito tempo, numa modulação gutural, disseram velhas cantigas dos tempos da Dinastia Ming, ao som de guitarras recobertas de peles de serpente, que dois tártaros agachados repenicavam, numa cadência melancólica e bárbara. A China tem encantos de um raro gosto... (QUEIRÓS, 1992a, p. 141).

Este jantar acontecera em homenagem a Teodoro que, a fim de "misturar à vida de Pequim" (QUEIRÓS, 1992a, p.139) e realizar seu plano de espantar o fantasma do mandarim Ti-Chin-Fú, decide se vestir à chinesa. Quando veste com sua "túnica de brocado azul-escuro abotoada ao lado, com o peitilho ricamente bordado de dragões e flores de oiro" (QUEIRÓS, 1992a, p. 139) já sente "ideias, instintos chineses: - o amor dos cerimoniais, o respeito burocrático das fórmulas, uma ponta de cepticismo letrado; e também um abjecto terror do Imperador, o ódio dos estrangeiros, o culto dos antepassados, o fanatismo da tradição, o gosto das coisas açucaradas...” (QUEIRÓS, 1992a, p. 141).

Ora, o que Eça de Queirós está traçando aqui, nada mais é que o estereótipo chinês para o europeu mediano, que já identificamos anteriormente em seus textos jornalísticos. Aqui, destacamos uma característica que ainda não havia aparecido em nossa análise: o ódio ao estrangeiro. Ela nos será fundamental, como apontaremos adiante.

No entanto, antes, vale a pena abrirmos um rápido parêntese em nossa análise para aprofundarmos um aspecto já notado nos textos jornalísticos de Eça. A cena de Teodoro se vestindo à chinesa é capital para vermos que as ideias em relação ao "outro" não são exclusivamente do ocidental para o oriental. Em outras palavras, estamos destacando ao longo de todo nosso estudo a visão do Extremo Oriente presente nas obras de Eça, logo, nosso estudo se baseia nos estudos orientalistas. E não poderia ser 
de outra forma, uma vez que nosso objeto de análise (Eça de Queirós) foi um europeu, criado e tendo passado quase toda sua vida em território europeu. No entanto, é interessante notarmos que ao mesmo tempo em que existe o "orientalismo", o inverso, o "ocidentalismo" também existe ${ }^{111}$. O que queremos dizer é que, essa relação entre um “eu” e o "outro" não é um caminho de mão única, mas um caminho de mão dupla. Afinal, se "eu" crio uma imagem em relação ao um "outro", este também cria uma imagem em relação a "mim". Embora aparentemente óbvio, muitas vezes este fato é esquecido. É este caminho inverso que Eça tentou reproduzir em seus artigos da década de 90, a destacar o artigo "Chineses e Japoneses". E é também esse caminho inverso que Eça criará, como veremos, aqui em $O$ Mandarim. Exemplificamos o que estamos querendo dizer sobre este "caminho inverso" com um texto de Okakura Tenshin.

Okakura Tenshin, pseudônimo de Okakura Kakuzo, (1862-1913), escritor e defensor da arte tradicional do Japão (que no final do século XIX passava por uma grande transformação, se "ocidentalizando" rapidamente), foi também um amante do sadô, a arte japonesa do chá. Em 1906, Okakura escreveu, em inglês, para o público euro-americano, seu consagrado The book of tea, que através de uma reflexão sobre a arte do chá, debate a relação entre Oriente e Ocidente nos últimos anos do século XIX e no começo do século $\mathrm{XX}^{112}$. Neste livro, Okakura diz sobre os japoneses que iam estudar no Ocidente: “Alguns de meus compatriotas exageraram na adoção de seus costumes e etiquetas, na esperança de que a aquisição de colarinhos engomados e cartolas de seda implicaria a conquista de sua civilização" (OKAKURA, 2008, p. 33). Okakura acaba por revelar o que Eça tinha ironizado na figura da Teodoro: a ideia de

\footnotetext{
${ }^{111}$ Assim como o orientalismo, o ocidentalismo também possui seus pensamentos teóricos. Destacamos aqui dois livros que tratam do tema: Occidentalism de Xiaomei Chen (1995) e Occidentalism. (A Short History of Anti Westernism) de Ian Buruma e Avishai Margalit (2004).

${ }^{112}$ Wenceslau de Moraes publicou em 1905, um ano antes de Okakura, uma obra intitulada $O$ Culto do Chá. Para uma análise comparativa destas duas obras com temáticas e datas tão próximas, Cf. HORIGOSHI, 2012, p. 80-107.
} 
que apenas através de uma vestimenta se aprenderia, magicamente, a cultura do "outro".

Ao defrontarmos Eça e Okakura, acabamos por perceber que a caracterização do “outro" é um processo mútuo, ou seja, caminhos iguais, porém em sentidos contrários. Portanto, mais uma vez, nota-se que Eça tinha essa consciência e a expôs diversas vezes em seus textos.

Retornando agora à análise específica de $O$ Mandarim, vemos que o momento que talvez melhor represente essa atmosfera edênica que Teodoro vive tanto na embaixada russa, como em toda a cidade Tártara, está na cena em que encontra, também vestida a chinesa, a generala Vladimira. Diz o trecho:

Como ela era linda vestida de dama chinesa! Nos seus cabelos levantados alvejavam flores de pessegueiro; e as sobrancelhas pareciam mais puras e negras avivadas a tinta de Nanquim. A camisinha de gaze, bordada a soutache de filigrana de oiro, colava-se aos seus seios pequeninos e direitos: vastas, fofas calças de foulard cor de rosa de ninfa, que lhe davam uma graça de serralho, recaíam sobre o tornozelo fino, coberto de meia de seda amarela: - e apenas três dedos da minha mão cabiam na sua chinelinha... [...]

$\mathrm{Eu}$ arregaçava-lhe a larga manga do casabeque de seda cor de folha morta, e ia fazendo viajar os meus lábios devotos pela pele fresca dos seus belos braços; - e depois sobre o divã, enlaçados, peito contra peito, num êxtase mudo, sentíamos as lâminas de cristal ressoar eoliamente as pegas azuis esvoaçarem pelos plátanos, o fugitivo ritmo do arroio corrente...

Os nossos olhos humedecidos encontravam às vezes um quadro de cetim preto, por cima do divã, onde em caracteres chineses se desenrolavam sentenças do Livro Sagrado de Li-Nun "sobre os deveres das esposas". Mas nenhum de nós percebia o chinês... E no silêncio os nossos beijos recomeçavam, espaçados, soando docemente, e comparáveis (na língua florida daqueles países) a pérolas que caem uma a uma sobre uma bacia de prata... - Oh suaves sestas dos jardins de Pequim, onde estais vós? Onde estais, folhas mortas dos lírios escarlates do Japão?...(QUEIRÓS, 1992a, p. 157-159)

É mordaz a ironia queirosiana nesta cena, ambos vestidos a chinesa, sem "perceber o chinês". A China acaba por ser rebaixada como um simples fetiche dos amantes que se encontram de baixo de palavras "sobre os deveres das esposas". Eça ironiza, portanto, todo o encantamento, todo a imaginário positivo, todo o "ideal de arte, 
requinte, fantasia delicada e fino prazer" (MARTINS, 1967, p.151) que Teodoro encontra na Cidade Tártara e, consequentemente, na embaixada russa.

Durante seu passeio por Pequim, guiado por Sá-Tó, Teodoro resolve atravessar o muro da cidade Tártara e conhecer a Cidade Chinesa, que descreve da seguinte maneira:

E lá fomos penetrando na Cidade Chinesa, pela porta monstruosa de Tchin-Men. Aqui habita a burguesia, o mercador, a populaça. As ruas alinham-se como uma pauta; e no solo vetusto e lamacento, feito da imundície de gerações recalcada desde séculos [...]

Dos dois lados são - ora terrenos vagos onde uivam manadas de cães famintos, ora filas de casebres fuscos, ora pobres lojas com as suas tabuletas esguias e sarapintadas, balouçando-se de uma haste de ferro. [...] Uma multidão rumorosa e espessa, onde domina o tom pardo e azulado dos trajes, circula sem cessar; a poeira envolve tudo de uma névoa amarelada; um fedor acre exala-se dos enxurros negros; [...]

Ao passar junto ao Templo do Céu, vejo apinhada num largo uma legião de mendigos; tinham por vestuário um tijolo preso à cinta num cordel; as mulheres, com os cabelos entremeados de velhas flores de papel, roíam ossos tranquilamente; e cadáveres de crianças apodreciam ao lado, sob o voo dos moscardos. Adiante topámos com uma jaula de traves, onde um condenado estendia, através das grades, as mãos descarnadas, à esmola... Depois Sá-Tó mostrou-me respeitosamente uma praça estreita: aí, sobre pilares de pedra, pousavam pequenas gaiolas contendo cabeças de decapitados: e gota a gota ia pingando delas um sangue espesso e negro... (QUEIRÓS, 1992a, p.145-147).

Aqui aparecem as primeiras descrições negativas. É de se notar que a Cidade Chinesa é destacada como o lugar onde "habita a burguesia, o mercador, a populaça".

Ou seja, há uma segregação da população, entre a nobreza letrada e o restante. A esses últimos, resta a miséria, imagem negativa já criada por Teodoro antes de sua viagem. Aos primeiros, estão reservados os prazeres da China idealizada. Em outras palavras, assim como em "Chineses e Japoneses", em que nós identificamos a construção da China do imaginário intelectual europeu com a classe letrada em contraste com a China emigrante, que se mostrava fechada e impenetrável, aqui também há uma separação clara: a cidade Tártara (bairro dos letrados), que concentra a tranquilidade, os jardins e a serenidade; e a cidade Chinesa (bairro da população trabalhadora), que se apresenta aos olhos europeus como "bárbaro" (QUEIRÓS, 1992a, p. 147), suja e podre. Teodoro 
também enxerga a todo o tempo a China como um lugar impenetrável. Ao final de seu passeio pela Cidade Tártara e pela Cidade Chinesa, diz:

Eu devorava, de olho ávido, esses monumentos da Antiguidade asiática, numa curiosidade de conhecer as impenetráveis classes que os habitam, o princípio das instituições, a significação dos cultos, o espírito das suas letras, a gramática, o dogma, a estranha vida interior de um cérebro de letrado chinês... Mas esse mundo é inviolável como um santuário... (QUEIRÓS, 1992a, p. 151, grifo nosso).

Ao fim de seu giro pelas ruas de Pequim, Teodoro adentra novamente a Cidade Tártara, correspondente à China da "voga parnasiana", e, com Camilloff, tem um diálogo em que o autor de $O$ Primo Basílio ironiza outros dois aspectos importantes da relação política da China com países do ocidente: o medo da "invasão amarela" e a visão limitada e redutora que Portugal tinha por suas colônias. Reproduzo o diálogo:

- Pequim faz-me sentir bem, general, os versos de um poeta nosso:

Sôbolos rios que vão

Por Babilónia me achei ...

- Pequim é um monstro! - disse Camilloff oscilando reflectidamente a calva. - E agora considere que a esta capital, à classe tártara e conquistadora que a possui, obedecem trezentos milhões de homens, uma raça subtil, laboriosa, sofredora, prolífica, invasora... Estudam as nossas ciências... Um cálice de Médoc, Teodoro?... Têm uma marinha formidável! O exército, que outrora julgava destroçar o estrangeiro com dragões de papelão donde saíam bichas de fogo, tem agora táctica prussiana e espingarda de agulha! Grave!

- E todavia, general, no meu país, quando, a propósito de Macau, se fala do Império Celeste, os patriotas passam os dedos pela grenha, e dizem negligentemente: Mandamos lá cinquenta homens, e varremos a China... (QUEIRÓS, 1992a, p. 151-153, grifo do autor).

Este trecho dialoga diretamente com dois textos jornalísticos de Eça: "A Marinha e a Colônia" de 1871 e, novamente, "Chineses e Japoneses" de 1894. Neste artigo, ao falar da adoção de técnicas militares ocidentais por parte dos chineses, diz que “tantos receiam e já profetizam uma invasão de bárbaros da Ásia” (QUEIRÓS, 2002, p. 540). Ora, é justamente esse medo de a China se tornar "a mais poderosa nação militar da Terra" (QUEIRÓS, 2002, p. 540) - ideia a qual refuta em seu artigo alertando que a questão que deve preocupar aos europeus e americanos é a imigração de trabalhadores, uma vez que o chinês é “um povo essencialmente pacífico” (QUEIRÓS, 2002, p. 540) - 
que Eça coloca na boca do general russo. Teodoro, por sua vez, acaba por revelar o pensamento de Portugal em relação a suas colônias por pensar que "mandamos lá cinquenta homens e varremos a China". Foi justamente o pensamento de abandono e desprezo da Metrópole em relação às colônias asiáticas que Eça ironizara quase dez anos antes n'As Farpas. Lá diz:

Que o País despreza as colónias; que elas estão abandonadas a uma frouxa iniciativa particular, sem estímulo, sem protecção, sem tranquilidade; que a energia individual só pode ser fecunda num país bem policiado; que nas colónias não há garantias de segurança, nem solicitude pelo comércio, nem polícia, nem higiene, nem instrução; que tudo ali vive na desordem, na desorganização, no desleixo, numa antiquíssima rotina; e que o único movimento é o do estrangeiro que as explora de facto - apesar de nós as possuirmos de direito. (QUEIRÓS, 2000a, vol. 3, p. 722).

Se, ao longo do passeio por Pequim, a Cidade Chinesa foi vista por características negativas, quando a suposta vila de Ti-Chin-Fú é descoberta e Teodoro parte a Tien-Hó à procura da família do mandarim assassinado, já no capítulo VI, a descrição feita pelo amanuense lisboeta é ainda pior. Narra a pequena vila da seguinte maneira:

Já a tarde declinava, e o Sol descia vermelho como um escudo de metal candente, quando chegámos a Tien-Hó.

As muralhas negras da vila erguem-se, do lado do sul, ao pé de uma torrente que ruge entre rochas: para o nascente, a planície lívida e poeirenta estende-se até a um grupo escuro de colinas onde branqueja um vasto edifício - que é uma missão católica. E para além, para o extremo norte, são as eternas montanhas roxas da Mongólia, suspensas sempre no ar como nuvens.

Alojámo-nos num barracão fétido, intitulado Estalagem da Consolação Terrestre. Foi-me reservado o quarto nobre, que abria sobre uma galeria fixada em estacas; era ornado estranhamente de dragões de papel recortado, suspensos por cordéis do travejamento do tecto; à menor aragem aquela legião de monstros fabulosos oscilava em cadência, com um rumor seco de folhagem, como tomada de vida sobrenatural e grotesca.

Antes que escurecesse fui ver com Sá-Tó a vila: mas bem depressa fugi ao fedor abominável das vielas: tudo se me afigurou ser negro os casebres, o chão barrento, os enxurros, os cães famintos, a populaça abjecta... Recolhi ao albergue - onde arrieiros mongóis e crianças piolhosas me miravam com assombro. (QUEIRÓS, 1992a, p. 163) 
Como dissemos, Coimbra Martins fez a associação dessas descrições negativas com o contato de Eça com a colônia chinesa, classificando esta como a "verdadeira" China. Aqui, concordamos com Carlos Jorge (1999, p. 253) quando este diz que não podemos classificar essa China como "verdadeira". Também nos é impossível precisar com exatidão o quanto essa experiência influenciou na construção dos espaços da Cidade Chinesa e de Tien-Hó. Mas, ao resgatarmos o relatório consular A Emigração como Força Civilizadora de 1874, encontramos algumas semelhanças. Lá, Eça havia dito:

É necessário vê-lo, em grupos, nos seus bairros para se compreender a hostilidade universal. Uma colônia china suja, mancha, desmoraliza uma cidade. Os casebres imundos em que vivem em aglomerações de 800 e 1000, na promiscuidade e no deboche, a sua sociedade sem mulheres, o seu traje sórdido, a sua fisionomia lívida viscosa e astuta, o seu ar desconfiado e avaro, a sua língua áspera e inacessível, tudo provoca, nas nossas ideias cultas e refinadas, um retraimento geral (QUEIRÓS, 2000a, vol. 3, p. 2081).

Obviamente aqui não estamos falando que esta visão de Tien-Hó é a visão de Eça. Mas nos parece lícito ler que Eça tenha se valido de sua própria visão juvenil da colônia chinesa para, seis anos mais tarde, ironizá-la transferindo esta imagem para os olhos de Teodoro. Parece-nos claro que Eça sabia que esta imagem que ele transmitira em seu relatório consular era uma imagem comum. Então, por que não imaginar que Eça, mais maduro intelectualmente, já em $O$ Mandarim debochava dessa visão europeia que julgava os orientais inferiores? Ou, por que não acreditar que, "o conto [...] nos apresenta uma sátira do próprio discurso que parece reproduzir" (SAPEGA, 2002, p. 445)?

Após o retorno à hospedaria, Teodoro e Sá-Tó vão dormir, mas logo são atacados pela população.

Era talvez já meia-noite quando despertei a um rumor lento e surdo que envolvia o barracão - como de forte vento num arvoredo, ou uma maresia grossa batendo um paredão. Pela galeria aberta, o luar entrava 
no quarto, um luar triste de Outono asiático, dando aos dragões suspensos do tecto formas, semelhanças quiméricas...

Ergui-me, já nervoso - quando um vulto, alto e inquieto, apareceu na faixa luminosa do luar...

- Sou eu, Vossa Honra! - murmurou a voz apavorada de Sá-Tó.

E logo, agachando-se ao pé de mim, contou-me num fluxo de palavras roucas a sua aflição: - enquanto eu dormia, espalhara-se pela vila que um estrangeiro, o Diabo estrangeiro, chegara com bagagens carregadas de tesouros... Já desde o começo da noite ele tinha entrevisto faces agudas, de olho voraz, rondando o barracão, como chacais impacientes... E ordenara logo aos koulis que entrincheirassem a porta com os carros das bagagens, formados em semicírculo à velha maneira tártara... Mas pouco a pouco a malta crescera... Agora vinha de espreitar por um postigo: e era em roda da estalagem toda a populaça de Tien-Hó, rosnando sinistramente... A deusa Kaonine não se satisfizera com o sangue do galo preto!... Além disso ele vira à porta de um pagode uma cabra negra recuar! ... A noite seria de terrores!... E a sua pobre mulher, o osso do seu osso; que estava tão longe, em Pequim!... (QUEIRÓS, 1992a, p.165)

A imagem do "diabo estrangeiro" se faz mais uma vez presente. Teodoro supunha ter sentido a aversão ao estrangeiro quando se vestiu à chinesa. Aqui, ele sente, como vítima, este ódio. Mais uma vez, Eça usa-se dessa imagem que parece ser bastante característica para nosso autor quanto às ideias da China em relação ao outro. Em “Chineses e Japoneses" ele também usará, como vimos, este aspecto quando tentava fazer sua "reflexão em mão dupla" (OLIVA, 2008, p.76).

Portanto, aqui também, Eça acaba por traçar um imaginário duplo: o imaginário europeu em relação ao chinês e o imaginário chinês em relação ao europeu. Eça, nesta cena, ainda brinca com as crenças chinesas, quando Sá-Tó garante segurança a Teodoro porque sacrificou "antes de partirmos, um galo, negro, e a deusa Kaonine deve estar contente" (QUEIRÓS, 1992a, p. 163). Obviamente a crença de Sá-Tó de nada adianta e o "diabo estrangeiro" e seu guia são atacados impiedosamente.

Entretanto, não é a primeira vez que, nesta novela, Eça expõe a visão dos chineses em relação ao europeu. Ainda quando habitava a embaixada russa, Teodoro contou ao general Camilloff suas intenções de se casar com a viúva de Ti-Chin-Fú. Logo, é alertado da impossibilidade de realização de suas pretensões: 
O meu estimável hóspede pretende esposar uma senhora da família TiChin-Fú, continuar a grossa influência que exercia o Mandarim, substituir, doméstica e socialmente, esse chorado defunto... Para tudo isto dispõe da palavra "chá". É pouco.

Não pude negar - que era pouco. $\mathrm{O}$ venerando russo, franzindo o seu nariz adunco de milhafre, pôs-me ainda outras objecções que eu via erguerem-se diante do meu desejo como as muralhas mesmas de Pequim: nenhuma senhora da família Ti-Chin-Fú consentiria jamais em casar com um bárbaro; e seria impossível, terrivelmente impossível que o imperador, o Filho do Sol, concedesse a um estrangeiro as honras privilegiadas de um mandarim...

- Mas porque mas recusaria? - exclamei. - Eu pertenço a uma boa família da província do Minho. Sou bacharel formado; portanto na China, como em Coimbra, sou um letrado! Já fiz parte de uma repartição pública... Possuo milhões... Tenho a experiência do estilo administrativo.......]

- Não é - disse ele enfim - que o imperador realmente o recusasse: é que o indivíduo que lho propusesse seria imediatamente decapitado. A lei chinesa, neste ponto, é explícita e seca.

$-[\ldots]$ Se eu entregasse metade dos meus milhões ao Tesouro chinês, já que não me é dado pessoalmente aplicá-los, como mandarim, à prosperidade do Estado...? Talvez Ti-Chin-Fú se calmasse...

O general pousou-me paternalmente a vasta mão sobre o ombro:

- Erro, considerável erro, mancebo! Esses milhões nunca chegariam ao Tesouro imperial. Ficariam nas algibeiras insondáveis das classes dirigentes: seriam dissipados em plantar jardins, coleccionar porcelanas, tapetar de peles os soalhos, fornecer sedas às concubinas: não aliviariam a fome de um só chinês, nem reparariam uma só pedra das estradas públicas... Iriam enriquecer a orgia asiática. A alma de Ti-Chin-Fú deve conhecer bem o Império: e isso não a satisfaria.

- E se eu empregasse parte da fortuna do velho malandro em fazer particularmente, como filantropo, largas distribuições de arroz à populaça faminta? É uma ideia...

- Funesta - disse o general, franzindo medonhamente o sobrolho. - A corte imperial veria aí imediatamente uma ambição política, o tortuoso plano de ganhar os favores da plebe, um perigo para a Dinastia... O meu bom amigo seria decapitado... É grave... (QUEIRÓS, 1992a, p. 135-137).

Aqui se destaca, além dessa tentativa de conhecer o pensamento do outro através da personagem Camilloff, mais uma vez, a ironia queirosiana na ingenuidade e a falta de compreensão do "outro" por parte de Teodoro que o julga com seus próprios valores. Afinal, parece ser incompreensível para Teodoro como ele pode ser julgado como "bárbaro" se é bacharel formado e proveniente de uma boa família minhota.

Retornando ao capítulo VI, quando atacados pelos moradores de Tien-Hó, Teodoro e Sá-Tó são afugentados, sendo quase mortos. É interessante notar como Eça 
de Queirós, mais uma vez, trata o conflito entre o Ocidente e o Oriente. Assim como aparece em "Chineses e Japoneses", Eça parece não acreditar em uma convivência pacífica. Há uma incompreensão mútua. Teodoro não compreende a China, os moradores da vila também não o compreendem. A consequência disso é o conflito.

Teodoro reencontra sua "China edênica" no convento dos Lazaristas, lugar onde encontra abrigo após a fuga de Tien-Hó. Suas idealizações voltam e Padre Giulio, líder dos Lazaristas, lhe parece um sábio chinês.

O superior lazarista era o excelente padre Giulio. A longa permanência entre as raças amarelas tornara-o quase um chinês: quando eu o encontrava no claustro com a sua túnica roxa, o rabicho longo, a barba venerável, agitando devagar um enorme leque parecia-me algum sábio letrado mandarim comentando mentalmente, na paz de um templo, o Livro Sacro de Chu. Era um santo: mas o cheiro de alho que exalava - afastaria as almas mais doloridas e precisadas de consolação. (QUEIRÓS, 1992a, p. 173).

No entanto, passa a odiar a China que encontrara fora dos muros da Cidade Tártara, fora da embaixada, fora de suas idealizações. Pela primeira vez, parece criar certa consciência da limitação de sua visão, mas nunca deixa de enxergar o chinês de maneira redutiva.

Eu por mim não contei no convento as minhas aventuras fantásticas: dei-me como um touriste curioso, tomando apontamentos pelo universo. E esperando que a minha orelha cicatrizasse, abandonavame, numa lassidão de alma, àquela paz de mosteiro...

Mas estava decidido a deixar bem depressa a China, esse império bárbaro que eu odiava agora prodigiosamente!

A minha ideia de ressuscitar artificialmente, para bem da China, a personalidade de Ti-Chin-Fú, parecia-me agora absurda, de uma insensatez de sonho. Eu não compreendia a língua, nem os costumes, nem os ritos, nem as leis, nem os sábios daquela raça: que vinha pois fazer ali senão expor-me, pelo aparato da minha riqueza, aos assaltos de um povo que há quarenta e quatro séculos é pirata nos mares e traz as terras varridas de rapina?... (QUEIRÓS, 1992a, p. 175, grifo nosso).

É interessante como Teodoro nunca deixa de ver o dinheiro como seu. Para si, aparece como um salvador incompreendido dos filhos daquele "império bárbaro" (FRIER, 2010, p. 156). 
Notável também é como Eça coloca uma visão similar do "outro" tanto do ponto de vista chinês quanto do ponto de vista europeu. "Para os Chineses, Teodoro era uma bárbaro com o qual nenhuma senhora da família do Mandarim poderia casar. Para Teodoro, aquele mundo era bárbaro e duro.” (DAVID, 2007, p. 73). A incompreensão, a visão redutora e idealizada é mútua.

Nesta passagem, a crítica de Eça nos parece ser idêntica à que ele faz em “Chineses e Japoneses", em 1894. Ou seja, percebemos que suas ideias transmitidas no artigo publicado pela Gazeta de Notícias do Rio de Janeiro já se faziam presentes em sua mente catorze anos antes. Só que, ao confrontarmos os textos, verificamos que Eça trata de maneiras contrárias ideias semelhantes. Se em "Chineses e Japoneses" o escritor destaca as fechadas colônias chinesas que se formam nos lugares em que os filhos do Império do Meio emigram, em $O$ Mandarim, vemos o processo oposto: colônias europeias que se formam em território chinês que, igualmente, não o penetram e, aparentemente, nem tentam penetrar. A Europa e China são, no fundo, representadas de jeitos similares. Assim como os chineses que emigram nada buscam além de trabalho e se fecham em suas colônias, onde vivem "de uma existência só chinesa, tendo já ao lado um esquife chinês para que, apenas morto, o reconduzam dentro dele à grande China" (QUEIRÓS, 2002, p. 596), Teodoro não busca no “Oriente nenhuma iluminação regeneradora para a civilização ocidental” (GROSSEGESSE, 2000, p. 767). Em momento algum, seja em suas leituras antes de embarcar para a China, seja durante sua estadia na embaixada russa, seja em sua viagem até Tien-Hó, Teodoro tenta aprender qualquer coisa com o chinês. Em certo momento até diz ter "curiosidade de conhecer as impenetráveis classes” (QUEIRÓS, 1992a, p. 151), mas nada busca por considerar de antemão que “esse mundo é inviolável como um santuário” (QUEIRÓS, 1992a, p. 151). Para o ex-amanuense, representante do europeu mediano finissecular, não se pode 
aprender com o chinês. Julgando-os inacessíveis desde o início de sua viagem, nunca busca a China. Por outro lado, a população chinesa de Tien-Hó também nada tenta aprender com Teodoro. Considerando-o "diabo estrangeiro", ataca-o sem qualquer explicação, ou melhor, baseado em um imaginário comum. Há, assim, uma crítica a ambos, Europa e Oriente, que estando em contato não convivem, não dialogam, não interagem e, assim, nada aprendem.

Deste modo, Eça percebe o problema da cultura nas relações internacionais, o que vem referendar teorias contemporâneas do importante papel que cumpre a cultura no processo de expansão global do capitalismo.

Pudemos ver também que de $O$ Mistério da Estrada de Sintra a $O$ Mandarim muita coisa mudou na representação do Extremo Oriente. É possível notar que durante a década de 70, muitas ideias se amadureceram na mente de Eça e, assim, as críticas se tornaram mais densas e mais profundas. As ideias de Eça em relação ao Extremo Oriente em 1880 já são muito próximas das que irá transmitir em seus textos jornalísticos da década de 90. No entanto, se de $O$ Mistério da Estrada de Sintra para $O$ Mandarim o Extremo Oriente foi desenhado de maneira bastante distinta, uma caracterização ainda mais diversa será feita em A Correspondência de Fradique Mendes, objeto de nossa análise no próximo item deste capítulo.

\subsection{O EXTREMO ORIENTE EM A CORRESPONDÊNCIA DE FRADIQUE}

\section{MENDES}

Embora tenha sido reunida em um volume apenas em 1900, A Correspondência de Fradique Mendes teve uma longa gestação, sendo trechos publicados desde 1888 em diversos periódicos como o jornal português O Repórter, a Revista de Portugal e o 
jornal carioca Gazeta de Notícias. Ainda, parte do material que compõe edições mais recentes do livro não foi publicada em vida por Eça e, igualmente, ficou fora da publicação em livro de 1900. Estes fragmentos vieram à luz apenas em 1912 com a compilação Últimas Páginas. A reunião do material publicado em vida por Eça e as cartas de Fradique Mendes publicadas postumamente se deu na edição de Obras Completas organizada por Beatriz Berrini e publicada pela editora Nova Aguilar do Rio de Janeiro ${ }^{113}$.

Fradique Mendes, no entanto, não é uma criação exclusiva de Eça. Nem sua concepção data da segunda metade da década de 80. O "primeiro Fradique Mendes", como o chama Joel Serrão (1985), data de “entre os fins de 1868 ou começos de 1869 e Maio ou Junho de 1869" (SERRÃO, Joel, 1985, p. 197) e se trata de um "heterônimo de uma geração cultural que, entre risadas e angústias, procurava escavar caminhos novos” (SERRÃO, Joel, 1985, p. 197). Um poeta satânico, criação coletiva de Eça de Queirós, Antero de Quental e Jaime Batalha Reis, que "tinha como principal intuito zombar da sociedade burguesa, assombrando-a” (THIMÓTEO, 2002, p. 833). Jaime Batalha Reis, em seu texto "Anos de Lisboa” publicado no In Memoriam de Antero de Quental, diz sobre a criação de Fradique:

Um dia, pensando na riqueza imensa do moderno movimento de ideias, cuja existência parecia ser tão absolutamente desconhecida em Portugal, pensando na apatia chinesa dos lisboetas, imobilizados, durante anos na contemplação e no cinzelar de meia ideia, velha, indecisa, em segunda mão, e em mau uso, - pensávamos em suprir uma das muitas lacunas lamentáveis criando ao menos, um poeta satânico. Foi assim que apareceu Carlos Fradique Mendes.

O nosso plano era considerável e terrível: Tratava-se de criar uma filosofia cujos ideais fossem diametralmente opostos aos ideais geralmente aceites, deduzindo, com implacável e impassível lógica, todas as consequências sistemáticas dos pontos de partida, por monstruosas que elas parecessem. Dessa filosofia saía naturalmente uma poesia, toda uma literatura especial, que o Antero de Quental, o Eça de Queirós e eu, nos propúnhamos construir a frio, aplicando os

\footnotetext{
113 Cf. a tabela com a publicação de cada parte tanto de "Memórias e Notas" quanto da "Correspondência", desde 1888 até a edição das Obras Completas no ano 2000, feito por Giuliano Lellis Ito Santos (2011, p. 139).
} 
processos revelados pelas análises da Crítica moderna, desmontando e armando a emoção e o sentimento como se fossem máquinas materiais conhecidas e reproduzíveis (REIS, 1985, p. 321).

Ou seja, depreende-se que o objetivo deste "primeiro" Fradique Mendes é próximo ao que, poucos anos mais tarde, Eça de Queirós e Ramalho Ortigão teriam ao criar $O$ Mistério da Estrada de Sintra e As Farpas. Não será por acaso, portanto, que Fradique Mendes aparecera nos trechos finais de $O$ Mistério da Estrada de Sintra, fazendo jogo heteronímico com os autores e com a obra em si. Cito:

F... e Carlos Fradique Mendes achavam-se há dias em uma quinta dos subúrbios de Lisboa escrevendo, debaixo das árvores e de bruços na relva, um livro que estão fazendo de colaboração, e no qual [...] levarão a pontapés ao extermínio todos os trambolhos que as escolas literárias dominantes em Portugal têm querido sujeitar as invioláveis liberdades do espírito (QUEIRÓS e ORTIGÃO, 1951, p. 243).

O "primeiro" Fradique Mendes teve publicado quatro poemas em agosto de 1869 na Revolução de Setembro (SERRÃO, Joel, 1985, p. 204) e "pouco tempo depois, a 5 de Dezembro do mesmo ano, O Primeiro de Janeiro, publicava novos quatro textos da coletânea Poemas de Macadam" (REIS, 1999, p. 137). A produção artística atribuída a Fradique Mendes ainda é composta por uma série de "cinco ou seis poesias, reunidas em folhetim sob o título de LAPIDÁRIAS" (QUEIRÓS, 1997, vol. 2, p. 57), conforme é dito na década de 80 .

Passado o período do Cenáculo, Fradique Mendes foi deixado por seus criadores, sendo retomado por Eça de Queirós, na segunda metade da década de 80 . Quem irá resgatar a figura de Fradique será o que a crítica denominou o "Último Eça" ${ }^{114}$. Quando se fala de "Último Eça" tem-se em mente um Eça posterior a publicação de Os Maias, ou seja, um Eça que já finalizara toda sua produção de cunho realista-naturalista. Em datas, é atribuído o período que vai de 1888, ano da publicação de Os Maias, até 1900, ano de sua morte. Vale destacar que Os Maias foi a última obra

\footnotetext{
${ }^{114}$ António José Saraiva (2000, p. 131-148) denomina esse período de "O Fradiquismo", em que considera Carlos Fradique Mendes uma evolução de Carlos da Maia e representante do pensamento queirosiano de sua última década de vida.
} 
publicada por Eça em vida, sendo que a partir de 1888, publicaram-se trechos de obras que viriam a ganhar sua versão em livro postumamente ou contos em periódicos portugueses, brasileiros ou franceses. Por isso, toda a produção atribuída ao "Último Eça" foi classificada como "semipóstuma"115. Assim como apontamos rapidamente ao citar o livro A Cidade e as Serras, os romances do "Último Eça" obtiveram uma recepção crítica inconstante ao longo dos anos. Miguel Real (2006) divide a recepção crítica de Eça em três períodos: Período Testemunhal (1900-1930); Período de Balanço (1930-1950) e Período Crítico (1950-2000), sendo o primeiro caracterizado por "artigos e livros que prestam testemunho da vida e obra de Eça de Queirós” (REAL, 2006, p. 22), o segundo pelos "primeiros estudos biográficos sérios, o que vai resultar na sistematização pormenorizada da vida e da obra de Eça de Queirós, bem como a contextualização histórica e social das fases de sua obra" (SANTOS, 2011, p. 12) e a terceira por "atribuir um valor menor à relação [...] entre a vida e a obra de Eça de Queirós do que o atribuído no período anterior, e como consequência, por interpretar textos que compõem a obra deste autor com maior objetividade ou rigor científico" (REAL, 2006, p. 35). Ou seja, esse último período é caracterizado pela revisão das leituras (SANTOS, 2011, p. 18) feitas até então. Não nos cabe aqui analisar detalhadamente cada um dos períodos da recepção crítica desse último período literário de Eça ${ }^{116}$. No entanto, muitos críticos resumem esse período do seguinte modo:

Vista em perspectiva o conjunto da recepção crítica sobre Eça de Queirós caracteriza o último Eça como um escritor preocupado em representar a aristocracia, metido num espaço rural, menos objetivo e menos contundente nas suas críticas do que o Eça naturalista, ainda que algumas leituras rompam com essa linha dominante da fortuna crítica. No caso das leituras biográficas, o último Eça é apresentado de forma a que tenha aderido à causa aristocrática, essencialmente, por motivo de seu casamento. [...] Ainda existem leituras que veem, nos últimos anos de Eça, um amadurecimento por conta da idade, que permite ao escritor representar pensamentos mais complexos do que

\footnotetext{
${ }^{115}$ Cf. REIS, 1990, p. 232-233.

${ }^{116}$ Para tal objetivo, cf. SANTOS, 2011, p. 9-24.
} 
os que eram apresentados nos seus livros naturalistas (SANTOS, 2011, p. 24).

Assim, conclui-se que no "Último Eça" temos

um Eça de Queirós mais perspicaz na sua visão da sociedade, do que aquele jovem que via a crítica como material para a mudança do país. Pode-se entender, então, que após a formação do grupo dos Vencidos da Vida, há um reconhecimento da derrota, ao menos do projeto inicial, da ideologia das Conferências do Casino. Isso obriga Eça de Queirós a buscar uma nova forma para a representação da sociedade. (SANTOS, 2011, p. 24).

Apesar de a publicação em livro A Correspondência de Fradique Mendes ter começado em 1888 em $O$ Repórter, a ideia de Eça de resgatar o antigo "heterônimo de uma geração cultural” (SERRÃO, Joel, 1985, p. 197) vem de três anos antes. Em carta a Oliveira Martins de 10 de junho de 1885, Eça diz:

Tenho andado com um tal período de estupidez que não só não te pude mandar um bocado de prosa bem confeccionada - mas nem tive a coragem de te anunciar um plano de trabalho que me lembrara para a Província. Não se podem fazer promessas literárias quando se está tão singularmente estúpido. O que eu pensei foi - uma série de cartas sobre toda sorte de assuntos, desde a imortalidade da alma até ao preço do carvão, escrita por um certo grande homem que viveu aqui há tempos depois do cerco de Tróia, e antes do de Paris, e que se chamava Fradique Mendes! Não te lembras dele? Pergunta ao Antero. Ele conheceu-o (QUEIRÓS, 2000a, vol. 4, p. 240, grifo do autor).

E prossegue, dando uma caracterização de Fradique, como um homem que

realmente existiu:

Homem distinto, poeta, viajante, filósofo nas horas vagas, diletante e voluptuoso, este gentleman, nosso amigo, morreu. E eu, que o apreciei e tratei em vida e que pude julgar da pitoresca originalidade daquele espírito, tive ideia de recolher a sua correspondência, - como se fez para Balzac, M. ${ }^{\text {me }}$ de Sévigne, Proudhon, Abélard, Voltaire e outros imortais - e publico-a ou desejo publicá-la na Província. Fradique Mendes correspondia-se com toda a sorte de gentes várias, all sort of men como se diz na Bíblia oficial desta terra. Escreve a poetas como Baudelaire, a homens de estado como Beaconsfield, a filósofos como S. ${ }^{\text {to }}$ Antero, e a elegantes como (não me lembra agora nenhum elegante a não ser o Barata Loura) e a personagens que não são nada disto, como o Fontes. Além disso tem amantes, e discute com elas a metafísica da voluptuosidade. E nas cartas ao seu alfaiate encontramse as regras mais profundas da arte de fascinar. Quando está viajando, está no Japão ou na Ásia Central, faz paisagem, quadros de costumes. E quando vem a Portugal, pinta aos seus amigos de Londres e de 
Berlim, as coisas e as ideias do Chiado, de S. Bento, das tabacarias e dos salões. [...]

Hem! Que assunto! E com este título modesto - Correspondência de Fradique Mendes. Precedida, está claro, por um estudo sobre a vida e opiniões desse lamentado gentleman. (QUEIRÓS, 2000a, vol. 4, p. 240-241).

É interessante notar que

já na apresentação da ideia, nota-se a busca de uma condição de realidade para Fradique, que pode ser constatada, não somente pela posição do narrador [...] mas pela referência a Antero como testemunho da sua existência [...] e pela comparação da publicação de suas cartas com a publicação da correspondência de personalidades como Balzac e Proudhon, entre outros (SANTOS, 2011, p. 134).

Ou seja, o que Eça faz aqui, em sua carta a Oliveira Martins, é o mesmo que ele faz com a sua obra sobre Fradique Mendes: uma obra ficcional com características de real, deixando no ar a dúvida entre a ficcionalidade e a facticidade do que se está lendo. Estratégia semelhante, ele fizera, como vimos, junto com Ramalho na publicação de $O$ Mistério da Estrada de Sintra.

Eça volta a tratar em 1888 da Correspondência de Fradique Mendes em outras cartas a Oliveira Martins. Destacamos duas: a primeira de 23 de maio de 1888 e a segunda de 12 de junho de $1888^{117}$. Na primeira, diz:

Tenho aqui para ti, isto é, para o Repórter, dadas certas condições, uma imensa quantidade de prosa. De fato todo um livro. Livro porém que se pode publicar aos bocados, todas as semanas, sem lhe prejudicar a unidade e o interesse. Compreenderás quando eu te disser que se chama - Correspondência de Fradique Mendes. Trata-se, como desde logo deduzes, de fazer para Fradique (não sei se te lembras desse velho amigo) o que está na moda fazer a todos os grandes homens que morrem - publicar-lhe as cartas particulares. Fradique foi um grande homem - inédito. Eu revelo-o aos meus concidadãos, publicando-lhe a correspondência. Se bem te recordas dele Fradique, no nosso tempo, era um cômico. Este novo Fradique que eu revelo é diferente - verdadeiro grande homem, pensador original, temperamento inclinado às ações fortes, alma requintada e sensível... Enfim o diabo! (QUEIRÓS, 2000a, vol. 4, p. 246).

Aqui, Eça não só, mais uma vez, "mantém seu discurso de fundamentação da existência empírica de Fradique" (SANTOS, 2011, p. 134), como também traça as

\footnotetext{
${ }^{117}$ O primeiro trecho de A Correspondência de Fradique Mendes foi publicado em agosto de 1888.
} 
diferenças do "primeiro" Fradique para o Fradique de A Correspondência, sendo o primeiro "um cômico" e o segundo, "alma requintada e sensível". Adiante, na mesma carta, fala da estrutura de seu texto, recordando Oliveira Martins que "não podia editar a correspondência de Fradique sem a preceder dum estudo sobre esta singular personalidade" (QUEIRÓS, 2000a, vol. 4, p. 246), e refutando a publicação no espaço do jornal dedicado ao folhetim: "No folhetim, não pode ser, porque se não pode interromper o romance nem eu quero que o estudo crítico sobre um tão grande homem apareça nesses baixos do jornal destinados à imaginação e à novela" (QUEIRÓS, 2000a, vol. 4, p. 246). Carlos Reis, sobre a recusa de Eça em publicar Fradique na parte dedicada ao folhetim, diz:

Vale a pena atentar no que estas palavras ocultam. Para Eça, não se trata apenas de insistir em 'efeitos de real' que já conhecemos (traços biográficos, conhecimento pessoal de Fradique, etc.): trata-se agora de reforçar esses efeitos propondo-se um 'estudo crítico' (nem sequer uma biografia formal), quer dizer, uma reflexão operada num registro não literário, porque se não deseja confundir Fradique com uma personagem de ficção; e trata-se também, para que não haja confusões, de afastar esse estudo da zona do jornal que poderia convidar a uma recepção de tipo literário. Depois de se insinuar, por processos diversos, a existência real de Fradique, procura-se agora desvanecer em definitivo as suspeições de ficcionalidade que sobre ele pudessem pairar. (REIS, 1999, p. 142).

Eça recebe a resposta de Oliveira Martins em que parece que o historiador não entendera exatamente qual era a intenção do amigo romancista. Então, em carta de 12 de junho de 1888, o autor de Os Maias explica sua intenção, retirando qualquer jogo entre ficção e realidade. Lá ele diz:

Recebi a tua boa carta. Não é possível, como propões, cortar os pedaços melhores do estudo Fradique, e alinhavá-los todos juntos num só artigo. Decerto me expliquei mal. A introdução a "Cartas que nunca foram escritas por um homem que nunca existiu", - não podia deixar de ser uma composição em que se tentasse dar a esse homem primeiramente realidade, corpo, movimento, vida. Não se pode decentemente publicar a Correspondência de uma abstração. De sorte que o tal estudo crítico é de fato uma novela - novela de feitio especial, didática e não dramática, mas enfim novela com uma narração, uma ação, episódios, uns curtos bocadinhos de diálogo, e até - paisagens. Desde logo vês que isto se não pode condensar, nem disto 
se podem fazer extratos. Tem de ser publicado tudo! Por outro lado sem prévia história do homem, é impossível encenar abruptamente as cartas. O público perguntaria naturalmente - "mas quem é Fradique?" (QUEIRÓS, 2000a, vol. 4, p. 248, grifo do autor).

Assim, Eça explicita sua intenção a seu amigo historiador, revelando-lhe todo o jogo entre realidade e ficção que pretendia fazer, mas sem deixar de "insistir naquilo que, afinal, era fundamental: a necessidade de se dar 'realidade, corpo, movimento, vida' a Fradique" (REIS, 1999, p. 143).

Embora a intenção de Eça fosse dar a Fradique um “estatuto de real” (SANTOS, 2011, p. 136), Carlos Reis já não considera o poeta criado como um heterônimo, conforme Joel Serrão definira o Fradique de 1869. Agora o trata como um protoheterônimo de Eça: "Carlos Fradique Mendes, sua biografia e seu conjunto epistolar que é publicado, tudo isso envolve uma estratégia global de tipo para-ficcional e préheteronímica ${ }^{118 "}$ (REIS, 1997, p. 72, tradução nossa), pois considera que "tanto a propensão epistolográfica como o estilo de Fradique não manifestam uma peculiaridade suficientemente distintiva para o afastar de Eça por inteiro" (REIS, 1999, p. 152). Ana Nascimento Piedade concorda com Reis ao afirmar que:

O apagamento plenamente deliberado do eu-Eça, em consonância com o surgimento estratégico do outro-Fradique como identidade psicológica e estético-literária inteiramente configurada e independente [...] não chegou nunca a ocorrer em grau suficientemente significativo, a não ser no 'plano onomástico'. Nos outros domínios, como o da biografia, o das ideias e, sobretudo, o do próprio estilo, não há diferenças apreciáveis. De facto, ao contrário do que acontece com Pessoa e o seu trio heterônimo, as principais ideias de Fradique não diferem substancialmente das de Eça, assim como a biografia de ambos integra alguns importantes factos coincidentes, como a viagem ao Oriente ou até título mais episódico, a comum preferência pelas famosas cabaias de seda, ou ainda, essa manifesta 'antipatia de instinto' expressa pelos diversos 'horrores' que ambos nutriam pelos políticos" (PIEDADE, 2003, p. 117).

\footnotetext{
118 "Carlos Fradique Mendes, sa biographie et l'ensemble épistolaire qui est publié de lui, tout cela implique une stratégie globale de type para-fictionel et pré-hétéronymique" (no original).
} 
Já Paulo Motta Oliveira argumenta que o Fradique de A Correspondência também pode ser considerado "como um heterônimo"119 (OLIVEIRA, P., 2001, p. 160), já que "se do primeiro Fradique tínhamos apenas alguns poemas e breves indicações biográficas, que foram publicadas junto com seus versos, desse outro temos uma biografia praticamente completa e um conjunto de cartas" (OLIVEIRA, 2000, p. 186). O estudioso vai mais longe, indicando o Fradique recriado da década de 80-90 também como um heterônimo coletivo. Cito:

a criação de Fradique já institui uma aura heteronímica, que, pouco depois, viria a eclodir de forma lapidar em Pessoa. Mas se Fradique [...] pode ser considerado como um heterônimo, parece-nos, diferentemente de Pessoa, esse será, mesmo em A Correspondência, um heterônimo coletivo (OLIVEIRA, 2000, p. 191).

É lembrado que os "outros dois pais do primeiro Fradique aparecem, neste livro de Eça, de formas especiais" (OLIVEIRA, 2000, p. 191, grifo do autor), sendo Jaime Batalha Reis sob o pseudônimo de J. Teixeira de Azevedo e, através de "alguns aspectos da biografia de Fradique - o fato de pertencer 'a uma velha e rica família dos Açores' e o de descender 'por varonia do navegador D. Lopo Mendes' que viveu no século XVI" aproxima-se "a biografia desse personagem" (OLIVEIRA, 2000, p. 191) com a de Antero de Quental.

Assim, por meio dessa questão heteronímica, pode-se perceber a ambiguidade presente entre as figuras de Fradique e de Eça. Ambiguidade essa que se agravará com a figura do narrador. Como se pode depreender da correspondência citada de Eça a Oliveira Martins, A Correspondência de Fradique Mendes é composta por duas partes.

\footnotetext{
${ }^{119}$ Eduardo Lourenço, em O Labirinto da Saudade, também considera o Fradique de A Correspondência como um heterônimo. Cito: "[...] É menos ou nada evocada primeira autêntica tematização do heteronimismo português, aquele que Eça realiza através da criação de Fradique Mendes, autor de Correspondência" (LOURENÇO, 2009, p. 93). Em Fernando, Rei da nossa Baviera (2008) a mesma ideia é apresentada: "Pessoa foi o termo de um claro processo de 'heteronimização' que tem as suas raízes em Garrett e já quase uma configuração pessoana em Eça de Queirós (Fradique) [...]. A criação de Fradique Mendes e, sobretudo, o espírito do seu retrato, como personagem de alma múltipla, capaz de esposar com igual paixão a indiferença religiões, metafísicas, costumes alheios, perfeito 'dandy' da verdade inacessível, anuncia e desenha já o espaço de um heteronimismo cultural de que Pessoa será, justamente, o mítico coroamento." (LOURENÇO, 2008, p. 15-16).
} 
A primeira, o "estudo crítico" da pessoa Fradique intitulado "Memórias e Notas" e a segunda, que trataremos mais adiante, composta pelas epístolas assinadas pelo protagonista. Cabe-nos agora tratar rapidamente da primeira parte, a biografia de Fradique Mendes elaborada, segundo nos afirma Carlos Reis, por um "narradoranônimo":

Uma das notas mais salientes que se deduzem da leitura da Correspondência de Fradique Mendes é o anonimato em que permanece o narrador homodiegético responsável pela introdução intitulada "Memórias e Notas". Recusando-nos a encarar este facto como um pormenor destituído de qualquer significado, defendemos a ideia de que ele nos abre caminho para uma primeira tentativa de explicação das intenções que presidem à concretização da instância narrativa: a elaboração de um retrato intelectual e moral da personagem cuja correspondência é divulgada, retrato esse delineado por alguém que, ocultando até a sua própria identidade, pretende apenas ser uma mera testemunha das facetas mais representativas da existência de Fradique (REIS, 1984, p 220).

No entanto, esse "narrador-anônimo" se torna uma figura ambígua, pois muitos dados de sua vida coincidem com a biografia de Eça. Em outro texto, Carlos Reis afirma-nos:

O caráter anônimo deste narrador institui uma ambiguidade que acaba por convir ao estatuto ontológico de Fradique Mendes, estatuto esse também um tanto ambíguo. De facto, o 'eu narrador' não é explicitamente o Eça de Queirós real, pois este não se situa (melhor: não se situou) no mesmo plano que o Fradique afinal imaginário; mas o anonimato [...] acaba por criar uma resistência à disjunção narradorEça, resistência favorecida também pela ocorrência de eventos que coincidem com a biografia queirosiana (por exemplo, a participação no Cenáculo e a viagem ao Egipto) e pela alusão a amigos do romancista (Antero, Junqueiro, O. Martins, etc) (REIS, 1999, p. 144).

Ana Nascimento Piedade também trabalha com "inegável disjunção entre o Eça-

autor e o (seu) narrador" (PIEDADE, 2002, p. 297), porém discorda em alguns aspectos de Carlos Reis. Cito:

O mesmo autor [Carlos Reis] entende que o anonimato 'acaba por criar uma resistência à disjunção narrador-Eça', aspecto com o qual discordamos, pois pensamos que precisamente esse fator de indeterminação, introduzido pela condição do anonimato, instaura uma atmosfera dúplice e ambivalente que ora ativa a não identificação entre as duas instâncias, atestada pelas inúmeras incongruências e dissonâncias que recheiam o texto de "Memórias e Notas", ora 
favorece a sua ligação, ilustrada pelas variadas coincidências biográficas que o mesmo texto também oferece (PIEDADE, 2002, p. 305 , grifo da autora).

Interessa-nos aqui, o fato dessa ambiguidade idealizada e criada por Eça expressar "através de uma combinação estratégica e peculiar de matizes vários, designadamente, um mistificador 'jogo' de espelhos, o fingimento irônico, um ludismo ambivalente e múltiplas 'distorções humorísticas"” (PIEDADE, 2002, p. 296). Assim, o retrato feito de Fradique em "Memórias e Notas" acaba por funcionar como um espécie de "exercício (disciplinador) da auto-ironia, entre Eça e Fradique” (PIEDADE, 2002, p. 298).

A imagem de Fradique que o narrador nos passa é, como também a criação de 1869, fragmentada. Ou seja, não é um retrato feito apenas pelas palavras do narrador. Para legitimar o jogo de real e para intentar a "totalidade mesmo conhecendo sua impossibilidade como afirma o narrador" (SANTOS, 2011, p. 140), a imagem de Fradique acaba por ser composta por "três fontes: 1. O testemunho de amigos; 2. As cartas de Fradique e 3. A convivência com o herói da narrativa" (SANTOS, 2011, p. 147). Ou seja, dentro da narração de "Memórias e Notas", Eça coloca trechos de textos ou cartas que amigos, alguns reais, outros ficcionais ${ }^{120}$, teriam escrito sobre Fradique. Também cita trechos de cartas que Fradique teria escrito, seja ao narrador, seja a algum desses amigos, além da narração de episódios de convívio entre o narrador e o protagonista da história. Assim, na formação de retrato de Fradique predomina

um plurivocalismo que surge expresso pela confrontação de diferentes pontos de vista emitidos por 'vozes' distintas: a do narrador, a de Fradique e as das diversas figuras cujos testemunhos, em princípio, adicionam informação e/ou consistência à personalidade do heróis (PIEDADE, 2003, p. 63).

\footnotetext{
${ }^{120}$ Nomeadamente são citados Ramalho Ortigão, Oliveira Martins, Guerra Junqueiro, Carlos Mayer, Antero de Quental, J. Teixeira de Azevedo e Marcos Vidigal.
} 
Uma vez que os trechos são selecionados pelo narrador e essas outras personagens falam através da voz desse "biógrafo", percebe-se que não estamos tratando de um texto isento. Há uma manipulação do narrador com o propósito de transmitir ao leitor uma imagem que lhe convém. Este objetivo, em linhas gerais, é criar uma imagem superior de Fradique. Assim, "o poeta das Lapidárias tem sua imagem formada por uma aura excepcional, o que leva à especulação da super-humanidade de Fradique" (SANTOS, 2011, p. 152). Este "estatuto em aparência super-humano" acontece

porque consegue conciliar em si mesmo, com harmonia verdadeiramente demiúrgica, facetas usualmente inconciliáveis em qualquer ser tangível. Sob um fundo de 'homem rico que vive bem', a nobreza, a elegância, a beleza, o encanto, a bondade e uma "altiva inteligência" (PIEDADE, 2002, p. 299).

Deste modo a imagem criada de Fradique "é a de um homem que viveu experiências extraordinárias e, mesmo sem deixar obra, ele deve ser inscrito na galeria de grandes homens". (SANTOS, 2011, p. 153). Em outras palavras, o que acaba por se desenhar pela voz do narrador é uma caricatura ${ }^{121}$ de um homem ideal do século XIX. Se levarmos em conta que Eça soube trabalhar como poucos a ironia, ganhando especial fineza nas obras da sua última década de vida ${ }^{122}$, Fradique Mendes pode ser lido, como também enxerga até certo ponto Ana Nascimento Piedade, como uma personagem de caráter irônico.

A segunda parte da obra é composta pelas cartas de Fradique a diversos destinatários, também alguns reais, outros ficcionais ${ }^{123}$.

Estas cartas seriam apenas algumas da "copiosa correspondência" (QUEIRÓS, 1997, vol. 2, p. 85) que Fradique mantinha "com toda a sorte de gentes várias"

\footnotetext{
${ }^{121}$ Ofélia Paiva Monteiro, em "Sobre a excentricidade humorística de Fradique" trata Fradique como uma junção de "estereótipos epocais" (MONTEIRO, 93/94, p. 207).

${ }^{122}$ Cf. SIQUEIRA, 2011, p. 68-69.

${ }^{123}$ Nomeadamente, estes destinatários são: Visconte de A. T.; Madame de Jouarre; Oliveira Martins; Madame S; Guerra Junqueiro; Ramalho Ortigão; Sr. E. Mollinet; Clara; Mr. M. Bertrand; Bento de S.; Sturmm; Manoel; ...; e Eduardo Prado.
} 
(QUEIRÓS, 2000a, vol. 4, p. 240). Assim, as cartas que são apresentadas na obra fazem parte de um cuidadoso selecionado feito por seu narrador, o que nos leva a crer que nenhuma carta está ali por acaso. Ainda, além das cartas, os destinatários também não são aleatórios.

Fradique adota estilos diversos adequando-os aos seus diferentes destinatários, e mais, adapta os assuntos e as temáticas ao horizonte de expectativa dos seus correspondentes: a Ramalho, por exemplo, narra um facto de interesse social, a Oliveira Martins expõe questões ligadas à História das Civilizações, a M. Bertrand, engenheiro, fala sobre os males do progresso, a Clara, num tom mais lírico e emotivo, aborda questões sentimentais (PEIXINHO, 2002, p. 344).

A ordem com que as cartas são dispostas também não é casual. Alguns destinatários recebem mais de uma carta ${ }^{124}$, no entanto, "nem sempre as cartas para a mesma pessoa são colocadas em sequência" (SANTOS, 2011, p. 168). Assim, "a mesma imagem figurada na primeira parte deve provavelmente figurar nesta, por meio da organização e seleção das cartas, já que, a linearidade da leitura [...] forma uma narrativa, se não pela temática, ao menos pela coerência autoral da assinatura" (SANTOS, 2011, p. 168).

Assim, cartas com temas diversos e propositadamente selecionadas fazem com que A Correspondência de Fradique Mendes aborde diversas questões das mais variadas áreas das humanidades em suas folhas. Somado isso ao caráter ambíguo e irônico não só da figura Fradique Mendes, mas também de seu narrador-biógrafo, surge a complexidade da obra e o interesse gerado nos estudiosos que permitem $A$ Correspondência de Fradique Mendes ter a vasta fortuna crítica que apresenta.

Passemos agora a analisar especificamente nosso objeto de estudo, o Extremo Oriente.

\footnotetext{
124 “A Madame de Jouarre” são cinco cartas, “a Clara” são quatro cartas e “a ...” são duas. Todos os outros destinatários recebem uma carta cada.
} 
A Correspondência de Fradique Mendes é uma das poucas obras ficcionais de Eça - talvez a única - onde o Oriente Próximo e o Extremo Oriente ganham contornos mais definidos, embora, deve-se ressaltar, aquele é tratado de maneira mais detalhada do que esse. Uma vez que Fradique foi um homem que viajou "por todo o mundo a todos os sopros do vento, desde Chicago a Jerusalém, desde a Islândia até ao Saara" (QUEIRÓS, 1997, vol. 2, p. 62-63) é natural que apareçam em seus textos impressões não só de um Oriente de predominância islâmica e um Oriente de predominância budista, como também de outras civilizações, como a europeia ou africana. Embora muitas vezes o Oriente de Fradique Mendes seja separado nessas duas microrregiões, há momentos, principalmente nas "Memórias e Notas", em que o Oriente é tratado como algo único. Por isso, em nossa análise, haverá reflexões sobre trechos referentes ao Oriente Próximo considerando-o, assim, equivalente ao julgamento a respeito do Extremo Oriente.

Como dito, em "Memórias e Notas", tanto o Extremo Oriente como o Oriente Próximo são abordados. Vale destacar que todo o capítulo III da primeira parte do livro trata do período em que o narrador anônimo e Fradique Mendes passaram juntos no Egito. O Oriente Próximo, na correspondência, ainda vai aparecer na carta XI, a Mr. Bertrand B., engenheiro na Palestina. Já o Extremo Oriente, na segunda parte do livro, aparece nas cartas V - a Guerra Junqueiro - e XVI - a Clara. Destas duas cartas trataremos adiante.

Em "Memórias e Notas", como dissemos, o narrador tenta criar uma imagem de homem ideal de Fradique. O autor das Lapidárias também é apresentado como um homem que viajou por todo o mundo, mas nunca como um "detestável touriste". O narrador diz: 
tipo de civilização mediano e genérico de onde saía e que preferia. Fradique amava logo os costumes, as ideias, os preconceitos dos homens que o cercavam: e, fundindo-se com eles no seu modo de pensar e de sentir, recebia uma lição directa e viva de cada sociedade em que mergulhava. (QUEIRÓS, 1997, vol. 2, p. 96-97).

Embora Fradique se considere, em carta a Oliveira Martins, "simplesmente um touriste $^{125 ”}$ (QUEIRÓS, 1997, vol. 2, p. 90), o narrador reforça, por diversas vezes ao longo do texto, que

Fradique não se limitava [...] a exames exteriores e impessoais, à maneira de quem numa cidade do Oriente, retendo as noções e os gostos de Europeu, estuda apenas o aéreo relevo dos monumentos e a roupagem das multidões. Fradique [...] transformava-se em "cidadão das cidades que visitava" (QUEIRÓS, 1997, vol. 2, p. 90).

Assim, o narrador tenta passar ao leitor das epístolas fradiquistas a imagem de europeu superior, aquele que não apenas visita os lugares, mas que tenta aprender com a cultura com que entra em contato. Deste ponto de vista, Fradique Mendes acaba sendo a única personagem queirosiana que busca nas culturas que visita o aprendizado, que enxerga o "outro" passível de ensinamento. Desta forma, pode-se ver que o "Último Eça", do mesmo modo que busca uma nova forma de representação da sociedade, também caracteriza de maneira original o europeu dentro da dicotomia OrienteOcidente. Fradique Mendes, num primeiro momento, já não representa mais aquele europeu imperialista ou concordante com tal política. Portanto, ele acaba por ser a única personagem à qual podemos aproximar à teoria orientalista de Schwab (1950), quer dizer, um viés mais positivo do contato entre o Ocidente e o Oriente.

As viagens de Fradique, como parece ter ficado claro, não são exclusivamente ao Oriente, afinal, ele "trilhou os cinco continentes" (QUEIRÓS, 1997, vol. 2, p. 108). Ao Oriente (tanto o Próximo quanto ao Extremo Oriente), é nos dado que Fradique visitou quatro vezes (QUEIRÓS, 1997, vol. 2, p. 95): uma ao Egito - que integra toda parte III de "Memórias e Notas"; uma a Jerusalém - "sua derradeira residência em

\footnotetext{
${ }^{125}$ Para interessantes considerações sobre Fradique enquanto turista e antropólogo, Cf. SILVESTRE, 2002.
} 
Jerusalém [...] foi motivada [...] por poéticos amores com uma das mais esplêndidas mulheres da Síria" (QUEIRÓS, 1997, vol. 2, p. 95); uma "peregrinação pela China, desde o Tibete (onde quase deixou a vida, tentando temerariamente penetrar na cidade sagrada de Lahsá) até à alta Manchúria” (QUEIRÓS, 1997, vol. 2, p. 96), onde “o mais completo estudo até hoje realizado por um homem da Europa sobre os Costumes, o Governo, a Ética e a Literatura desse povo" foi feito (QUEIRÓS, 1997, vol. 2, p. 96); e outra a um local não identificado. Talvez, essa última viagem ao Oriente tenha sido a Septa-Sindhou ${ }^{126}$, local a que se referiu em carta a Guerra Junqueiro. Também é relatado que Fradique "se preparava (quando a morte o surpreendeu) a voltar à Índia, para se tornar budista praticante, e penetrar cabalmente o Budismo, em que fixara a curiosidade e actividade crítica dos seus derradeiros anos" (QUEIRÓS, 1997, vol.2, p. 91).

Outros dados da relação de Fradique com o Oriente são informados em "Memórias e Notas". Por exemplo, o narrador observa que o poeta da Lapidárias “conhecia também o árabe, que [...] falava com abundância e gosto" (QUEIRÓS, 1997, vol. 2., p. 93) e que, em determinada altura, se tornara adepto do Babismo (QUEIRÓS, 1997, vol. 2., p. 79). Ainda, objetos orientais possuídos por Fradique Mendes também são referidos.

Apesar desta imagem de europeu especial criada em torno da figura Fradique, vale destacarmos que ele não deixa de ter, por vezes, atitudes de "europeu mediano". Isto é, assim como parte da elite europeia via no fato de possuir objetos oriundos do Oriente uma forma da busca de um cosmopolitismo e, assim, um status maior perante a sociedade, Fradique também busca em objetos orientais fineza e requinte. Além das porcelanas da China (QUEIRÓS, 1997, vol. 2, p. 101) na casa de Fradique, Eça de

\footnotetext{
${ }^{126}$ Pela descrição dada na carta a Guerra Junqueiro, Septa-Sindhou estaria localizada onde, hoje, é o Paquistão e parte do Afeganistão. Na época, fazia parte da Índia Britânica.
} 
Queirós veste sua personagem, assim como vestira Teodoro e assim como vestira, de maneira irônica, a si mesmo ${ }^{127}$, com uma cabaia de seda chinesa. Isto é relatado no primeiro encontro entre o narrador e Fradique, ainda em 1867, em Lisboa: "Fradique Mendes voltara de dentro, vestido com uma cabaia chinesa! Cabaia de mandarim, de seda verde, bordada a flores de amendoeira - que me maravilhou e me intimidou" (QUEIRÓS, 1997, vol. 2, p. 68). Esta cabaia é, em outros momentos, relembrada pelo narrador $^{128}$, mostrando ser uma vestimenta largamente utilizada por Fradique. É interessante notar que em muitos momentos que o narrador cita a cabaia chinesa de Fradique, a referência é acompanhada de expressões de admiração da parte do narrador além do tom de superiodade que a figura de Fradique assume. Cito: "Depois, enfiando uma das cabaias de seda que tanto me maravilhavam, abandonava-se, estirado numa poltrona, aos cuidados de Smith que, como barbeiro (afirmava Fradique), reunia a ligeireza macia de Figaro à sapiência confidencial do velho Oliveiro de Luis XI" (QUEIRÓS, 1997, vol. 2, p. 101, grifo nosso);

Quando eu conheci Fradique em Lisboa [...] julguei sentir na sua natureza (como no seu verso), uma impassibilidade brilhante e metálica: e através da admiração que me deixara a sua arte, a sua personalidade, o seu viço, a sua cabaia de seda - confessei [...], que não encontrara no poeta das LAPIDÁRIAS aquele tépido leite da

\footnotetext{
${ }^{127}$ Eça de Queirós recebeu, em 1889, de seu amigo Conde de Arnoso uma cabaia de seda chinesa e chá como presentes de uma viagem à China. Com esta cabaia, Eça foi fotografo nos jardins de Neuilly, sua residência na França. Em agradecimento ao presente, Eça escrevera ao amigo uma carta em que brinca com os estereótipos chineses presentes no imaginário europeu. Reproduzo trechos da carta: "Recebi, há pouco, a suntuosa 'cabaia', e foi já revestido com ela, risonho e grave, que provei o chá da Terra das Flores. Com certeza me trouxeste da China um presente esplêndido! Mas tenho medo, amigo, de não ser competente para dignamente usar essa nobre vestimenta de Mandarim erudito! Oh, Bernardo, onde tenho eu as qualidades precisas para me poder encafuar com coerência dentro daquelas sedas literárias? Onde tenho eu o austero escrúpulo gramatical, a dogmática pureza da forma, a sólida gravidade dos conceitos, o religioso respeito da tradição, a serena e amável moral, o otimismo clássico de um bom letrado chinês, membro fecundo da Academia Imperial? Onde tenho eu sobretudo a pança para encher aquelas pregas amplas e mandarinais? Eu não tenho a pança! Nem a mão fina, de unhas ilimitadas, para sair com graça daquelas mangas abundantes e cheias de autoridade. Nada tenho para a 'cabaia' magnífica! Não podendo, portanto, usá-la sobre as costelas magras, vou dependurá-la na minha sala, como um desses quadros que decerto viste em Pequim, e onde se desenrola, bordado em seda, um forte preceito moral. O preceito, o conselho que me dará a tua 'cabaia', através das suas dobras mudas, é aquele que me daria qualquer Mandarim chinês que nelas estivesse envolvido e que para todos os efeitos, será sempre o mais sábio e prudente conselho a oferecer a um homem de letras: 'respeita a gramática e ganha barriga!'” (QUEIRÓS, 2000a, vol. 4, p. 301)

${ }^{128}$ Além dos trechos citados no texto, a cabaia de seda de Fradique é referida nas páginas 71, 72 e 84.
} 
bondade humana, sem o qual o velho Shakespeare (nem eu, depois dele), compreendia que um homem fosse digno da humanidade. (QUEIRÓS, 1997, vol. 2, p. 104, grifo nosso);

O ar de preeminência que a cabaia concede a Fradique acaba por transformá-lo em uma espécie de mandarim do imaginário europeu. Ou seja, Fradique parece ter "o austero escrúpulo gramatical, a dogmática pureza da forma, a sólida gravidade dos conceitos, o religioso respeito da tradição, a serena e amável moral, o otimismo clássico de um bom letrado chinês, membro fecundo da Academia Imperial” (QUEIRÓS, 2000a, vol. 4, p. 301), que Eça ironizara em sua carta ao Conde de Arnoso e, assim, se torna, aos olhos do narrador, um "ser competente para dignamente usar essa nobre vestimenta de Mandarim erudito" (QUEIRÓS, 2000a, vol. 4, p. 301). Sob este ponto de vista, temos uma imagem do Oriente do "biógrafo" de Fradique. O narrador de "Memórias e Notas" reproduz através de seu olhar, todo o imaginário do "ideal parnasiano" que comentamos na análise de $O$ Mandarim. No entanto, este não é o único momento em que a visão de Oriente do narrador anônimo é exposta. Como já referido, a parte III de "Memórias e Notas" narra o encontro do narrador com Fradique em terras egípcias. Lá, diz o narrador:

As iluminações no Oriente consistem, como as do Minho, de tigelinhas de barro e de vidro onde arde um pavio ou uma mecha de estopa. Mas a descomedida profusão, com que se prodigalizam as tigelinhas (quando as paga o Paxá), torna as velhas cidades meio arruinadas, que assim se enfeitam em louvor de Alá, realmente deslumbrantes - sobretudo para um ocidental besuntado de literatura, e inclinado a ver por toda a parte, reproduzidas no moderno Oriente, as muito lidas maravilhas dessas Mil e Uma Noites que ninguém jamais leu (QUEIRÓS, 1997, vol. 2, p. 77).

Mais uma vez, o narrador propaga a imagem de um Oriente mágico, baseado na literatura. Ou seja, a imagem que Eça, mais de uma vez, coloca é a que classificara em seus textos jornalísticos como de um europeu mediano. Adiante, deixa de transmitir 
apenas as imagens do "Oriente mágico" para olhar, se não negativamente ${ }^{129}$, como uma região superficialmente compreendida. O narrador fala da "monotonia com que o chinês apara todas as árvores dum jardim, até lhes dar a forma única e dogmática de pirâmide ou de vaso funerário" (QUEIRÓS, 1997, vol. 2, p. 100) e adiante de caridade genuinamente budista (QUEIRÓS, 1997, vol. 2, p. 93, 105). Ora, apontar que o trabalho chinês como algo monótono, sugere um julgamento através de princípios próprios em detrimento a uma tentativa de compreensão do que lhe é "diferente"; e indicar como adjetivação a uma atitude a expressão "budista" não deixa de ser a propagação de um estereótipo criado em torno dos praticantes do budismo.

A imagem criada pelo narrador sempre funciona como um contraponto para a imagem de Fradique do Oriente. Ou seja, enquanto o narrador tem visões comuns de um europeu, Fradique é aquele que "sabia a raça, a história, os costumes, o lugar próprio" (QUEIRÓS, 1997, vol. 2, p. 77) das civilizações. Desta forma, nesta obra a personagem que acaba por reproduzir a visão padrão da população europeia não é Fradique Mendes, mas sim o organizador da correspondência do poeta das Lapidárias. Tal fato também é útil ao biógrafo, pois, assim, consegue corroborar a aura divina (QUEIRÓS, 1997, vol. 2, p. 73) com que deseja impregnar a imagem de Fradique.

Retornando à visão de Fradique a propósito do Oriente, notamos que o poeta, em diversos momentos, compara Ocidente e Oriente equiparando um ao outro, sem tomar uma posição de preferência a nenhum deles. O que, num primeiro momento, pode parecer uma posição semelhante à que Eça assumiu em alguns de seus textos jornalísticos, acaba por, em uma análise mais detida, reproduzir mais um lugar comum de um orientalismo positivo. Cito um trecho relevante:

\footnotetext{
${ }^{129}$ Uma imagem negativa será mais fortemente marcada em relação aos negros. Cito: "Terminei por perguntar ao negro de Seneh que servia o macarrão. O selvagem escancarou um riso de faiscante alvura no ébano do carão redondo, e através da mesa, grunhiu com respeito: - Cé-le-dieu!' (QUEIRÓS, 1997, vol. 2, p. 73, grifo nosso).
} 


\begin{abstract}
A Dança e a Poesia, afirmava Fradique, as duas grandes artes orientais, iam em misérrima decadência. Numa e outra se tinham perdido as tradições do estilo puro. As almées, pervertidas pela influência dos casinos do Ezbequieh onde se perneia o cancã - já poluíam a graça das velhas danças árabes, atirando a perna pelos ares à moda vil de Marselha!

E na Poesia triunfava a mesma banalidade, mesclada de extravagância. As formas delicadas do classicismo persa nem se respeitavam, nem quase se conheciam; a fonte da imaginação secava entre os muçulmanos; e a pobre Poesia Oriental, tratando temas vetustos com uma ênfase preciosa, descambara, como a nossa, num Parnasianismo bárbaro. . .

- De sorte - murmurei - que o Oriente...

- Está tão medíocre como o Ocidente. (QUEIRÓS, 1997, vol.2, p. 81)
\end{abstract}

Ao nivelar os dois grandes "blocos", Fradique rebaixa o Oriente à decadência que sentia na sociedade ocidental. Assim, acaba por lamentar a perda da "pureza" da arte oriental, "poluída" pela influência ocidental. Indignação semelhante Fradique reproduzirá na carta XI, a Mr. Bertand B.

Assim, aos poucos, apesar das sucessivas tentativas do narrador de conferir a seu amigo o estatuto de homem "de todas as civilizações [...] antropologicamente ideal" (REAL, 2007, p. 131), Fradique vai se mostrando como um intelectual europeu típico, como se vestisse uma máscara, através da qual aparenta uma superioridade intelectual, mas que, apesar de seus esforços para absorver tantas civilizações (QUEIRÓS, 1997, vol. 2, p. 108), não deixa de reproduzir um discurso orientalista padrão ${ }^{130}$.

Antes de analisarmos as cartas de Fradique a Guerra Junqueiro e a Clara, destacamos, por fim, que a visão das colônias portuguesas na Ásia que Eça desenha desde As Farpas, faz-se presente também em "Memórias e Notas". Sobre Marcos Vidigal, parente e amigo de autor das Lapidárias que também dá seu testemunho para criar a imagem de Fradique do narrador, é dito em determinado momento: "Marcos

\footnotetext{
${ }^{130}$ Osvaldo Manuel Silvestre vai além e lê a visão de Fradique como colonialista. Cito: "Fradique faz aqui uma reivindicação de autenticidade que é, indistintamente, uma imposição de etnicidade. A Palestina é a Bíblia viva, pelo que são nela impensáveis os comboios (e, supõe-se, a indústria): Fradique, podemos admiti-lo, não se importaria que, a bem do culto das origens, o Ocidente declarasse a Palestina como 'reserva cultural'. A Palestina, enfim, ou é nativista ou não poderá de todo ser. [...]. Trata-se, como é bom de ver, de uma argumentação não apenas ocidental mas colonial: Fradique decreta o 'puro Oriente' como quem, por essa via, institucionaliza o Outro" (SILVESTRE, 2002, p. 228).
} 
Vidigal, que, através da Revolução de Setembro, trepara da Crónica Musical à Administração Civil, governava a Índia como Secretário-Geral de novo entregue, nesses ócios asiáticos que lhe fazia o Estado, à História da Música e à concertina" (QUEIRÓS, 1997, vol. 2., p. 71, grifo nosso). Adiante, fala-se que "[Fradique] perguntou-me pela pachorrenta Lisboa, por Vidigal que burocratizava entre os palmares bramânicos...” (QUEIRÓS, 1997, vol. 2., p. 73, grifo nosso) Assim, a Índia Portuguesa aparece, mais uma vez, como um território inútil a Portugal, afinal seus administradores nada fazem, sobrando-lhes tempo para se dedicar "à História da Música e à concertina".

Passando, então, à analise do Extremo Oriente na segunda parte do livro, isto é, à parte correspondente às epistolas de Fradique em si, vemos que o extremo asiático, diferentemente do Oriente Próximo (na carta XI A Mr. Bertrand B.) não tem uma reflexão específica sobre si. O Extremo Oriente, na segunda parte do livro, se faz presente através de análises sobre o budismo. Ironicamente, é-nos dado que o budismo (refletido tanto no texto a Guerra Junqueiro quanto a Clara) foi o único assunto que Fradique não conheceu a fundo. Pois "se preparava (quando a morte o surpreendeu) a voltar à Índia, para se tornar budista praticante, e penetrar cabalmente o Budismo, em que fixara a curiosidade e atividade crítica dos seus derradeiros anos" (QUEIRÓS, 1997, vol. 2, p. 91). Não nos parece ser por acaso tal ironia. Portanto, quando o Budismo é tratado por Fradique, deve-se levar em conta que não estamos falando de mais uma religião sorvida e estudada a fundo pelo poeta, como o Babismo. É de ter em vista que o conhecimento de Fradique acerca do Budismo não ultrapassa ao dos estudos em livros e do conhecimento difundido na Europa.

O Budismo, em A Correspondência de Fradique Mendes, é sempre tratado pela comparação. Este método comparativo de Fradique é considerado por Miguel Real 
(2007, p. 127) como uma das novas estratégias discursivas desse "Último Eça""131. Este método não será apenas utilizado para tratar do Budismo, mas também, como destaca Giuliano Lellis Ito Santos, "se pode destacar a comparação entre tempos diversos, encontrados em algumas cartas de Fradique Mendes: carta III a Oliveira Martins, carta XI a Mr. Bertrand B., carta XXI a Manoel e carta XXII a ...” (SANTOS, 2011, p. 176).

Como se pode perceber através das análises que viemos fazendo ao longo deste estudo, A Correspondência de Fradique Mendes é o único texto em que Eça trabalha com o Budismo. Miguel Real lê isto como natural, pois "a reflexão operada por Eça de Queirós sobre Buda e o Budismo só poderia ter lugar na fase da sua evolução literária designada por 'Último Eça"” (REAL, 2007, p. 128). Considerando “A Correspondência de Fradique Mendes um autêntico ensaio epistolar sobre o Amor, a Religião, o Ecletismo de fim de século, o Homem Antigo e o Homem Democrata, Portugal..." (REAL, 2007, p. 128) o estudioso vê no humanismo ${ }^{132}$, conceito que resumiria as características da escrita dessa última fase de Eça, a principal justificativa para um pensamento acerca do Budismo ser feito apenas por um Eça maduro. Não se trata de discordar com essa leitura de Miguel Real, mas, do mesmo modo que separamos a figura do narrador da de Eça, aqui preferimos ler as impressões expostas sobre o Budismo como um pensamento da personagem Fradique, em detrimento de uma correlação das palavras do poeta das Lapidárias diretamente com o pensamento do autor de $O$ Mandarim.

A carta a Guerra Junqueiro trata primordialmente das religiões e suas cerimônias. Fradique diz que "as Religiões para os homens [...] não passa dum conjunto

\footnotetext{
${ }^{131}$ As outras características são: “a revisão subjetiva das impressões psicológicas, fundadas na memória pessoal"; e "revisitar, momento a momento, tema a tema, os "momentos emocionais", além de "questionar e de problematizar, à luz do pensamento da década de 90, os grandes temas filosóficos vividos pela Geração de 70" (REAL, 2007, p. 126-127).

132 "Humanismo enquanto filosofia defensora de uma autenticidade humana com intervenção social activa no sentido de generalizar o bem entre os povos sem a submissão a uma escola partidária ou filosófica única" (REAL, 2007, p. 128)
} 
de Ritos, através dos quais cada povo procura estabelecer uma comunicação íntima com o seu Deus e obter dele favores" (QUEIRÓS, 1997, vol. 2, p. 127). E, para corroborar sua visão de que todas as religiões são semelhantes, resolve "viajar" com seu interlocutor a Septa-Sindhou, no Extremo Oriente ${ }^{133}$. Dissemos "viajar", pois a estratégia narrativa de Fradique é de justamente simular uma viagem a essas terras, contando os fatos como se o poeta e seu interlocutor estivessem presenciando bem diante de seus olhos. Fradique escreve:

suba comigo por essa antiguidade fora até um sítio bem cultivado e bem regado que fica entre o rio Indo, as escarpas do Himalaia, e as areias dum grande deserto . Estamos aqui em Septa-Sindhou, no país das Sete Águas, no Vale Feliz, na terra dos Árias. No primeiro povoado em que pararmos, V. vê, sobre um outeiro, um altar de pedra coberto de musgo fresco: em cima brilha palidamente um fogo lento: e em torno perpassam homens, vestidos de linho, com os longos cabelos presos por um aro de ouro fino. São padres, meu amigo! São os primeiros capelães da Humanidade, - e cada um deles está, por esta quente alvorada de Maio, celebrando um rito da missa Ariana. (QUEIRÓS, 1997, vol. 2, p. 127).

Continua a descrever o ritual rudimentar dos Arianos, destacando que "não há metafísica, nem ética [...]. Há meramente uma liturgia, uma totalidade de Ritos, que o Ária necessita observar para que Indra [Deus] o atenda [...]" (QUEIRÓS, 1997, vol. 2, p. 128). Até que o poeta conclui: "Esta religião primordial é o tipo absoluto e inalterável das Religiões, que todas por instinto repetem - e em que todas (apesar dos elementos estranho de Teologia, de Metafísica, de Ética que lhe introduzem os espíritos superiores) terminam por se resumir com reverência” (QUEIRÓS, 1997, vol. 2, p. 128).

Adiante, Fradique finaliza sua "viagem" a Septa-Sindhou com Guerra Junqueiro não apenas igualando todos os ritos religiosos do mundo, como também equiparando todas as religiões de todos os tempos: "O que V. observou em Septa-Sindhou poderá verificar igualmente parando [...] na Antiguidade Clássica, em Atenas ou Roma, onde

\footnotetext{
${ }^{133}$ Septa-Sindhou, como destacamos anteriormente, corresponde hoje ao território do Paquistão e parte do Afeganistão, duas repúblicas islâmicas. Tal fato poderia encaixar tais regiões, de acordo com nossa divisão, dentro do Oriente Próximo. Porém, justificamos nossa inclusão dentro do Extremo Oriente pelo fato de, no final do século XIX, ela ainda fazer parte da Índia Inglesa.
} 
quiser, no momento de maior esplendor e cultura das civilizações greco-latinas" (QUEIRÓS, 1997, vol. 2, p. 128).

A estratégia de Fradique para corroborar sua ideia é pegar o lugar mais simples de um lugar distante, no caso, o Extremo Oriente, e mostrar a prática religiosa mais "pura" - o que vimos, é valorizado por Fradique - que conhece para colocá-la como a essência de todas as religiões. Assim, após comparar práticas religiosas de tempos distintos (religiões da antiguidade com as religiões contemporâneas), confronta as "duas grandes Religiões do Ocidente e do Oriente” (QUEIRÓS, 1997, vol. 2, p. 129), ou seja, o Catolicismo e o Budismo.

Fradique diz:

E se, já farto destes tempos antigos, V. quiser volver aos nossos filosóficos dias, encontrará nas duas grandes Religiões do Ocidente e do Oriente, no Catolicismo e no Budismo, uma comprovação ainda mais saliente e mais viva de que a Religião consiste intrinsecamente de práticas, sobre as quais a Teologia e a Moral se sobrepuseram, sem as penetrarem, como um luxo intelectual, acessório e transitório flores pregadas no altar pela imaginação ou pela virtude idealista. (QUEIRÓS, 1997, vol. 2, p. 129).

Fradique resume o Catolicismo "a uma curta série de observâncias materiais" (QUEIRÓS, 1997, vol. 2, p. 129) onde tudo tem por objetivo "servir a Deus, que é o meio de agradar a Deus" (QUEIRÓS, 1997, vol. 2, p. 129, grifo do autor). Novamente iguala todas as religiões do mundo, ao dizer que "de sorte que no catolicismo do Minhoto como na religião da Ária, em Septa-Sindhou como em Carrazeda de Anciães, tudo se resume em propiciar Deus por meio de práticas que o cativem" (QUEIRÓS, 1997, vol. 2, p. 130). Assim, chega ao Budismo, mas sem dar tons originais à análise feita:

Se tivéssemos tempo de ir à China ou a Ceilão, V. toparia com o mesmo fenómeno no Budismo. Dentro dessa Religião foi elaborada a mais alta das Metafísicas, a mais nobre das Morais: mas em todas as raças em que ele penetrou, nas bárbaras ou nas cultas, nas hordas do Nepal ou no mandarinato chinês, ele consistiu sempre para as multidões em ritos, cerimónias, práticas - a mais conhecida das quais 
é o moinho de rezar. V. nunca lidou com este moinho? É lamentavelmente parecido com o moinho de café em todos os países budistas V. o verá colocado nas ruas das cidades, nas encruzilhadas do campo, para que o devoto ao passar, dando duas voltas à manivela, possa fazer chocalhar dentro as orações escritas e comunicar com o Buda, que por esse acto de cortesia transcendente "lhe ficará grato e lhe aumentará os seus bens" (QUEIRÓS, 1997, vol. 2, p. 130).

Ou seja, ao analisar o Catolicismo e o Budismo, metonimicamente, o Ocidente e o Oriente, Fradique acaba por defender uma essência semelhante. Inclusive no desenvolvimento das religiões, Ocidente e Oriente parecem equivalentes para os olhos do poeta. Essa visão se assemelha à de Eça em alguns textos jornalísticos da década de 90, como vimos. No entanto, vale destacarmos o lamento de Fradique pelo instrumento que ele chama de "moinho de rezar". Ao lamentar a semelhança com um "moinho de café", objeto corriqueiro na sociedade ocidental, acaba por rebaixar a religião budista a algo mundano, podendo ser interpretado como um pesar de uma pureza, uma originalidade oriental antiga perdida, como vimos Fradique fazer em "Memórias e Notas" e como faz na carta XI a Mr. Bertrand B.

O poeta das Lapidárias continua a argumentar a Guerra Junqueiro sobre a equivalência de todas as religiões:

Para a vasta massa humana, em todos os tempos, pagã, budista, cristã, maometana, selvagem ou culta, a Religião terá sempre por fim, na sua essência, a súplica dos favores divinos e o afastamento da cólera divina; e, como instrumentação material para realizar estes objectos, o templo, o padre, o altar, os ofícios, a vestimenta, a imagem (QUEIRÓS, 1997, vol. 2, p. 131).

E finaliza de maneira extremamente irônica, dando a Guerra Junqueiro o único exemplo que conhece de religião sem uma liturgia. Um exemplo de uma tribo africana:

De resto, não se desconsole, amigo! Mesmo entre os simples há modos de ser religiosos, inteiramente despidos de Liturgia e de exterioridades rituais. Um presenciei eu, deliciosamente puro e íntimo. Foi nas margens do Zambeze. Um chefe negro, por nome Lubenga, queria, nas vésperas de entrar em guerra com um chefe vizinho, comunicar com o seu Deus, com o seu Mulungu (que era, como sempre, um seu avô divinizado). O recado ou pedido, porém, que desejava mandar à sua Divindade, não se podia transmitir através dos Feiticeiros e do seu cerimonial, tão graves e confidenciais matérias 
continha... Que faz Lubenga? Grita por um escravo: dá-lhe o recado, pausadamente, lentamente, ao ouvido: verifica bem que o escravo tudo compreendera, tudo retivera: e imediatamente arrebata um machado, decepa a cabeça do escravo, e brada tranquilamente "parte"! A alma do escravo lá foi, como uma carta lacrada e selada, direita para o Céu, ao Mulungu. Mas daí a instantes o chefe, bate uma palmada aflita na testa, chama à pressa outro escravo, diz-lhe ao ouvido rápidas palavras, agarra o machado, separa-lhe a cabeça, e berra: - "Vai!". Esquecera-lhe algum detalhe no seu pedido ao Mulungu...O segundo escravo era um post-scriptum...(QUEIRÓS, 1997, vol. 2, p. 132).

O Budismo, ou melhor, a figura de Buda, aparece em outra carta de Fradique Mendes. Estamos falando da carta XVI, a terceira das quatro cartas dedicadas a Clara, amante de Fradique. Esta carta se inicia com as justificativas de Fradique não ter escrito a Clara por certo tempo, seguido de algumas palavras de afeto. Então, já quase no meio da epístola, resolve falar sobre a figura de Buda.

E por história - muito aprovo, minha estudiosa Clara, que andes lendo a do divino Buda. Dizes, desconsoladamente, que ele te parece apenas um Jesus muito complicado. Mas, meu amor, é necessário desentulhar esse pobre Buda da densa aluvião de Lendas e Maravilhas que sobre ele tem acarretado, durante séculos, a imaginação da Ásia. Tal como ela foi, desprendida da sua mitologia, e na sua nudez histórica, - nunca alma melhor visitou a terra, e nada iguala, como virtude heróica, a Noite do Renunciamento. (QUEIRÓS, 1997, vol. 2, p. 175 , grifo do autor).

Aqui, é interessante notar que não nos é dado apenas uma visão de Fradique. $\mathrm{O}$ poeta, através de suas palavras, informa-nos também como Clara enxerga Buda. Ela o interpreta como "apenas um Jesus muito complicado". Ou seja, apesar de estar lendo a história de Buda, ela não o consegue compreender. A visão de Clara não deixa de ser próxima, em certos termos, à do narrador de "Memórias e Notas". Isto é, a visão do Oriente, suas culturas e seus personagens como incompreensíveis. Clara representaria, sob este ponto de vista, mais um "europeu mediano" das obras de Eça.

Já Fradique, não entende Buda como um ser divino. O poeta das Lapidárias destaca a necessidade de "desentulhar esse pobre Buda da densa aluvião de Lendas e Maravilhas". Isto é, ele não trabalha com Buda enquanto figura divinizada, superior. Ele 
analisa Buda enquanto ser humano. O mesmo será feito com a figura de Jesus ${ }^{134}$, que servirá como contraponto negativo a fim de exaltar a figura humana do criador do Budismo:

Jesus foi um proletário, um mendigo sem vinha ou leira, sem amor nenhum terrestre, que errava pelos campos da Galileia, aconselhando aos homens a que abandonassem como ele os seus lares e bens, descessem à solidão e à mendicidade, para penetrarem um dia num Reino venturoso, abstracto, que está nos Céus. Nada sacrificava em si e instigava os outros ao sacrifício - chamando todas as grandezas ao nível da sua humildade. O Buda, pelo contrário, era um Príncipe, e como eles costumam ser na Ásia, de ilimitado poder, de ilimitada riqueza: casara por um imenso amor, e daí lhe viera um filho, em quem esse amor mais se sublimara: - e este príncipe, este esposo, este pai, um dia. por dedicação aos homens, deixa o seu palácio, o seu reino, a esposada do seu coração, o filhinho adormecido no berço de nácar, e, sob a rude estamenha de um mendicante, vai através do mundo esmolando e pregando a renúncia aos deleites, o aniquilamento de todo o desejo, o ilimitado amor pelos seres, o incessante aperfeiçoamento na caridade, o desdém forte do ascetismo que se tortura, a cultura perene da misericórdia que resgata, e a confiança na morte... (QUEIRÓS, 1997, vol. 2, p. 175-176).

E prossegue:

Incontestavelmente, a meu ver [...] a vida do Buda é mais meritória. E depois considera a diferença do ensino dos dois divinos Mestres. Um, Jesus, diz: - "Eu sou filho de Deus, e insto com cada um de vós, homens mortais, em que pratiqueis o bem durante os poucos anos que passais na Terra, para que eu depois, em prémio, vos dê a cada um, individualmente, uma existência superior, infinita em anos e infinita em delícias, num palácio que está para além das nuvens e que é de meu Pai!". O Buda, esse, diz simplesmente: - "Eu sou um pobre frade mendicante, e peço-vos que sejais bons durante a vida, porque de vós, em recompensa, nascerão outros melhores, e desses outros ainda mais perfeitos, e assim, pela prática crescente da virtude em cada geração, se estabelecerá pouco a pouco na Terra a virtude universal!" A justiça do justo, portanto, segundo Jesus, só aproveita egoistamente ao justo. E a justiça do justo, segundo o Buda, aproveita ao ser que o substituir na existência, e depois ao outro que desse nascer, sempre durante a passagem na Terra, para lucro eterno da Terra. (QUEIRÓS, 1997, vol. 2, p. 176).

Comparações semelhantes, em que a figura humana de Buda é colocada acima

da de Jesus são postas até que Fradique conclui: "Eu, minha flor, sou pelo Buda" (QUEIRÓS, 1997, vol. 2, p. 176).

\footnotetext{
${ }^{134}$ A figura de Cristo será recorrente na obra de Eça. Para uma análise dos modos como Jesus é retratado em diferentes textos queirosianos, cf. BUENO, 2007.
} 
Fradique expõe sua preferência pela figura do príncipe indiano em relação a Jesus. Se pensarmos que, aqui, Buda e Jesus representam metonimicamente o que Budismo e Catolicismo representaram na carta a Guerra Junqueiro, ou seja, Oriente e Ocidente, temos uma visão de elevação do Oriente em relação ao Ocidente. Ou melhor, de maneira mais clara, vemos uma simpatia maior pela figura que foi a origem da religião budista, enxergando assim, uma religião que, em sua origem, foi mais "mais meritória". Como vimos, o Catolicismo e o Budismo modernos são equivalentes para Fradique, pois se resumem, como todas as religiões, a uma série de práticas que visam "a súplica dos favores divinos e o afastamento da cólera divina” (QUEIRÓS, 1997, vol. 2, p. 131). No entanto, na sua origem, parecem ser distintos, tendo, a religião budista, uma origem “mais meritória” (QUEIRÓS, 1997, vol. 2, p. 176) que o catolicismo.

Miguel Real (2007) em sua análise das mesmas cartas destaca o lado humanista de Eça, ao se centrar não nas figuras divinizadas, mas sim nas figuras humanas de Buda e Cristo.

Buda, enquanto homem religioso, assemelhar-se-ia, no Oriente, na sua forma paradigmática de conduta social e na virtude modelar da sua existência, a Cristo no Ocidente, ambos criadores de novas orientações civilizacionais fundadas no sobrenatural, diferenciando-se apenas no substrato cultural, social e religioso das tradições territoriais e geográficas em que nasceram. Em ambos, porém, segundo Eça de Queirós, seria absoluta a fantasia dominadora e reitora da História, nenhum deles possuindo, verdadeiramente, um vinculo directo com o sobrenatural senão o criado pela sua "fantasia" individual [...]. Eça de Queirós não crê na existência de Cristo e de Buda como seres divinos, mas exclusivamente como seres históricos, poderosamente "afirmativos" [...], criadores de doutrinas, regeneradoras e salvadoras do homem. Assim, é enquanto humanista [...] que Eça de Queirós cria a personagem cosmopolita e decadentista Carlos Fradique Mendes, que se manifesta interessado pelo Budismo (REAL, 2007, p. 134).

Não cremos ser equivocada a leitura de Miguel Real, uma vez que Fradique também se interessará pelo Babismo "não por admiração da doutrina, mas por 
veneração dos apóstolos ${ }^{135} "$ (QUEIRÓS, 1997, vol. 2, p. 79). Apenas parece-nos importante observar que, se postas linearmente, como uma sequência de uma reflexão, pode-se ler, mais uma vez, um apego de Fradique Mendes a um Oriente antigo imaculado, repetindo, desta forma, em diversas vezes um discurso caracteristicamente europeu.

Em suma, o Budismo para Fradique Mendes aparece, primeiramente, como "uma entre diversas crenças que o homem europeu refinado do final do século XIX deve 'experimentar' ou 'crer' para uma total compreensão da essência da religião e, por via desta, da essência do homem" (REAL, 2007, p. 135). No entanto, esta é a única religião que Fradique não pode absorver. Ironicamente, é uma das religiões mais tratadas por Fradique na segunda parte do livro. Assim, todo o julgamento que Fradique faz acerca do Budismo - embora enquanto religião a iguale a todas as outras e, em sua análise das figuras históricas, não apresente claramente uma visão da religião budista em si - é baseado em conhecimentos externos. Isso o difere dos outros assuntos tratados por Fradique, devidamente experimentamos e esgotados (QUEIRÓS, 1997, vol. 2, p. 94). Tal diferença faz-se fundamental pois, insistimos, Fradique Mendes, talvez pela impossibilidade de "experimentar", ratifica uma preleção eurocêntrica.

Dessa maneira, numa visão global, Eça nos dá algumas visões distintas do ponto de vista europeu em relação ao Oriente em A Correspondência de Fradique Mendes. Não apenas Fradique, mas também o narrador anônimo e Clara têm suas visões representadas. E esses dois últimos acabam por reproduzir lugares-comuns do pensamento a respeito do Extremo Oriente, demonstrando incompreensão e imagens já previamente formadas.

\footnotetext{
${ }^{135}$ Miguel Real (2007, p. 131) ainda lembra que processo semelhante de uma visão humanista de figuras religiosas será feito por Eça nas Lendas dos Santos, mais especificamente em "São Cristóvão".
} 
Apesar da tentativa do narrador de "Memórias e Notas" de exaltar Fradique enquanto homem superior do século XIX, tanto em "Memórias e Notas" quanto na sua correspondência que, teoricamente, apresenta uma leitura especial do Oriente, deixa-se escapar um Fradique que difere pouco de correntes de pensamento europeus sobre o Oriente. Lembramos, primeiramente, da larga utilização por Fradique da ironizada cabaia de seda e de sua porcelana chinesa. Ainda deve-se destacar que Fradique tende a ter uma visão positiva do Oriente, principalmente de seu passado - tido como "puro" que se perdeu diante da modernidade.

No entanto, ao recordarmos que Fradique também funciona como uma ironia do intelectual do século XIX, uma "espécie de caricatura de perfeição" (PIEDADE, 2002, p. 299), faz-se válida a leitura que Eça acaba por ironizar, também, essa faceta positiva do Oriente, considerada de certo modo uma leitura superior, adquirida por alguns intelectuais europeus ${ }^{136}$. Porém, a crítica de Eça parece não se resumir a tal fato. Se lembrarmos que Fradique Mendes não deixou nenhuma obra (QUEIRÓS, 1997, vol. 2, p. 107), e, portanto, nunca transmitiu a ninguém seus conhecimentos adquiridos - a exceção daqueles com que teria mantido regular troca de epístolas. Fradique acaba por se assemelhar a uma figura que Eça cita em “Chineses e Japoneses”. Lá, ele dissera:

Era um secretário da legação inglesa, que falava com perfeição o chinês, não só o idioma popular, mas a linguagem mandarina e clássica, e que deixara crescer um enorme rabicho. Durante trinta anos, todas as noites, este homem absolutamente achinesado vestia a sua cabaia de seda, soltava o rabicho, tomava um leque e ia passar algumas horas amáveis com as famílias nobres de Pequim. Esse realmente conheceu a China; mas, [...] não escreveu as suas impressões - e morreu. (QUEIRÓS, 2002, p. 532)

A busca de Fradique por outras culturas se pauta no "impulso de admirações ou de curiosidades intelectuais" (QUEIRÓS, 1997, vol. 2, p. 95). Assim, uma vez que

\footnotetext{
${ }^{136}$ Neste ponto, ao detectarmos as várias visões sobre o Oriente de A Correspondência de Fradique Mendes, chegamos ao conceito de polifonia, o que permite ler este texto como o mais moderno de Eça. Desta ideia, pode-se desenrolar uma leitura em que Eça, com esta obra, está produzindo uma literatura muito próxima da desenvolvida no século XX.
} 
Fradique é um ser humano cosmopolita que "realmente conheceu" inúmeras civilizações, Eça parece criticar um cosmopolitismo vão, pautado por um egoísmo que não contribui para um verdadeiro diálogo civilizacional, em que a cultura do "outro" deve servir como contraponto enriquecedor da sociedade em que se vive. Deste ponto de vista, a crítica de Eça em A Correspondência de Fradique Mendes funciona como uma nova representação da questão posta a propósito de um diálogo entre Oriente e Ocidente. Se, em $O$ Mandarim, Eça de Queirós representou em Teodoro um europeu que superficialmente entra em contato com a China, mas que não procura de fato compreender toda aquela civilização, o escritor aqui representa na figura de Fradique aqueles que realmente buscaram um aprendizado, mas que, uma vez que se restringiram a saciar uma curiosidade pessoal, não estabeleceram um diálogo em si e, assim, nada contribuíram para um melhor relacionamento entre diferentes culturas.

\subsection{CONCLUSÃO PARCIAL}

Assim como na análise dos textos não ficcionais de Eça de Queirós, ao analisar sua produção ficcional, tomamos o cuidado de selecionar obras de diversos momentos literários do autor. O Mistério da Estrada de Sintra (1870) foi a primeira obra escrita por Eça, em parceria com Ramalho Ortigão, momento próximo, porém anterior, à elaboração de As Farpas; O Mandarim (1880) está em um período importante da bibliografia queirosiana, pois foi concebida no momento em que o romancista se dedicava às obras realista-naturalistas, algumas publicadas apenas após sua morte: $O$ Crime do Padre Amaro (1875, a primeira versão; 1880 a última versão), $O$ Primo Basílio (1878) e Os Maias (1888), A Capital! (1925), O Conde de Abranhos (1925), A Tragédia da Rua das Flores (1980), etc.; e A Correspondência de Fradique Mendes 
(1900) pertence ao que ficou conhecido como o período do "Último Eça", fase madura, em que foram elaboradas as suas obras "semipóstumas", como Carlos Reis (1990) as classificou $^{137}$.

O Extremo Oriente nas obras ficcionais de Eça aparece de diversas maneiras. Desde simples objetos de decoração que representam uma aparente fineza e requinte na busca de um status social mais elevado até em questões políticas e econômicas como o imperialismo europeu na Ásia. Isso passando por outros pontos como a religião (tanto as missões portuguesas na Ásia, como aparece furtivamente em $O$ Crime do Padre Amaro, até tentativas de reflexões sobre as religiões asiáticas, como em $A$ Correspondência de Fradique Mendes) e, principalmente, a visão com que os europeus avaliam, julgam e tratam o Extremo Oriente e suas culturas.

Em O Mistério da Estrada de Sintra, encontramos um Extremo Oriente visto através dos olhos de um capitão inglês, Rytmel, na Índia. Suas terras são desenhadas por tons exóticos e seus habitantes são vistos como seres inferiores. Os olhos de Rytmel são os olhos de um colonizador. Lembrando que todo o livro é um grande "jogo humorístico", como Ofélia Paiva Monteiro $(1985,1987)$ descreveu, a visão de Rytmel funciona como uma paródia do discurso colonialista europeu e desse exotismo tipicamente atribuído ao Oriente.

Com as outras obras de Eça, o Extremo Oriente deixa de ter esse tom paródico evidente e passa à ironia mais refinada.

Em $O$ Mandarim, principal texto ficcional de Eça sobre o Extremo Oriente, é onde encontramos a reflexão mais completa sobre esta região do planeta. Nesta obra, Eça não se limita a caracterizar a China pelos olhos de Teodoro, um típico pequeno burguês lisboeta do final do século XIX, mas também tenta enxergar como os chineses

\footnotetext{
${ }^{137}$ Além de A Correspondência de Fradique Mendes, temos A Cidade e as Serras (1901) e A Ilustre Casa de Ramires (1900).
} 
viam os europeus, resultando no conflito que expulsa o protagonista da China. É evidenciada uma incompreensão mútua, uma falta de diálogo entre o Ocidente e o Oriente e, consequentemente, uma impossibilidade de convivência pacífica. Eça de Queirós ainda ironiza as maneiras - positiva e negativa - de como o Ocidente enxerga o Oriente e, de certa forma, também de como o Oriente enxerga o Ocidente.

A questão parece ficar mais complexa quando lemos A Correspondência de Fradique Mendes. Diferentemente de $O$ Mandarim, aqui não há uma análise em “mão dupla". No entanto, são transmitidas duas visões aparentemente distintas do Extremo Oriente, mas que, de acordo com nossa leitura, se aproximam. Uma é representada pelo narrador anônimo e por Clara, que se encaixam como típicos europeus que olham para o Oriente através de imagens prontas difundidas no Ocidente. Assim, é destacada a incompreensão e a análise superficial feita por europeus medianos acerca dos povos do Leste. A visão que nos é dada como a de Fradique é mais brumosa, pois devemos levar em consideração que a imagem do poeta das Lapidárias é mediada pelo narrador. Este descreve Fradique como um intelectual ideal do século XIX, aquele que vai a todas as partes do mundo e não as visita como um mero turista. Ele, diz o narrador, domina todas as culturas que entra em contato. No entanto, Fradique deixa escapar atitudes de típico intelectual do século XIX, que enxerga um Oriente antigo puro, lamentando seu estado presente. A ironia com que Eça desenha seu personagem faz com que ele troce também dessa visão positiva do Oriente. Embora seja a única personagem eciana que busca aprender e compreender o Oriente, a visão dele nunca deixa de ser algo parcial. Ainda, Fradique em momento algum tenta transmitir ao Ocidente o que aprendeu com o Oriente, afinal foi um homem sem obra. Toda sua busca por outras culturas é fruto do “impulso de admirações ou de curiosidades intelectuais" (QUEIRÓS, 1997, vol. 2, p. 
95). Deste modo, podemos ler tal fato como uma crítica à busca por um cosmopolitismo oco presente no final do século XIX que acaba por resultar em nada.

Dessa maneira, Rytmel, Teodoro e Fradique formam uma tríade irônica de Eça em relação à visão ocidental acerca do Oriente. São três abordagem distintas que, em diferentes graus, são criticadas pelo romancista lusitano: Rytmel, o militar colonizador que vai ao Oriente implantar a política imperialista europeia; Teodoro, o pequeno burguês (que acaba por se tornar elite no decorrer de sua história), que vai ao Oriente sem nada saber, e o interpreta de acordo com sua visão de mundo, julgando aquele mundo incompreensível e impenetrável; e Fradique, o intelectual que, embora busque aprender e entender o Oriente, nada faz com esse conhecimento, resultando em um cosmopolitismo vazio e sem razão de ser.

Somando a isso outras representações menores (decoração, missões religiosas, etc.) que destacamos em outras obras de Eça ou até mesmo nos textos que analisamos mais detidamente, percebemos que o Extremo Oriente na obra de Eça adquire a pluralidade e complexidade que a própria questão secular (ou talvez até, milenar) das relações entre Ocidente e Oriente possui. 


\section{CONSIDERAÇÕES FINAIS}

Em todos os gêneros de texto que Eça produziu - artigos e crônicas jornalísticas; romances e contos; relatórios consulares e correspondência pessoal - em algum momento, o Extremo Oriente é representado. Desde furtivos objetos de decoração em construções de cenários que por vezes passam despercebidos, até claras reflexões sobre política e história, inúmeros olhares são utilizados para caracterizar o Extremo Oriente e sua relação com a sociedade europeia finissecular. A pouca vivência e a necessidade de recorrer à literatura para reconstruir essa região do planeta se torna um ponto ínfimo se levarmos em conta a complexidade com que o Extremo Oriente é apresentado nos textos queirosianos.

Em nosso estudo buscamos analisar as várias maneiras como o Extremo Oriente aparece desenvolvido em textos diversos da produção queirosiana. Nosso recorte, tanto do ponto de vista temporal quanto do ponto de vista de gênero, nos permitiu percorrer, mesmo que a panoramicamente, a bibliografia queirosiana e, assim, começar a entender como o Extremo Oriente é encarado pelo autor de O Primo Basílio.

Ao estudarmos os textos não ficcionais, dos quais selecionamos textos jornalísticos e um relatório diplomático, pudemos constatar o desenvolvimento intelectual de nosso autor, em que a relação Ocidente-Oriente deixa de possuir matiz eurocêntrica, e passa a ser lida criticamente, culminando nos textos da Gazeta de Notícias na década de 1890. Em sua produção jornalística, vimos, assim, que Eça, através de sua ironia, passa a criticar a política imperialista e colonialista europeia, mas também censura a busca por trabalho pelos orientais que nada tentam aprender com o local onde passam a viver. Deste modo, Eça ironiza tudo: a Europa, sua política, seu 
modo de enxergar o outro; e o Oriente, sua política, seu relacionamento com o Ocidente e, também, seu modo de enxergar o Europeu.

$\mathrm{Na}$ análise dos textos ficcionais, em que escolhemos três obras dispostas cronologicamente em pontos distintos da bibliografia eciana, vimos que as personagens levadas pelo romancista lusitano às terras Orientais reproduzem diversos modos com que as várias camadas sociais europeias enxergavam o Oriente. Lá encontramos representada a visão do militar colonialista (Rytmel); do pequeno-burguês que posteriormente faz parte da elite europeia (Teodoro); e da intelectualidade, tanto a que está em formação (Artur), quanto a já formada (Fradique Mendes). Todas essas personagens se apresentam como paródias ou ironias do olhar europeu acerca do Oriente, embora a visão inversa também seja ironizada em $O$ Mandarim.

Verificamos que esses textos não são isolados uns dos outros. Ao contrário, existe um grande diálogo de ideias e imagens entre textos de diferentes gêneros. Por exemplo, estabelecemos diálogos de O Mistério da Estrada de Sintra com os textos de As Farpas, separados por aproximadamente um ano um dos outros. Os textos de 1871 ainda ecoam em $O$ Mandarim e A Correspondência de Fradique Mendes com a questão das colônias portuguesas que são indiretamente tratadas. $O$ Mandarim, por sua vez, além dos textos de As Farpas, dialoga tanto com outro texto anterior, o relatório $A$ Emigração como Força Civilizadora, quanto com textos posteriores, os textos "A França e o Sião", “Chineses e Japoneses" e "A Propósito da Doutrina Monroe e do Nativismo" da Gazeta de Notícias. Já A Correspondência de Fradique Mendes conversa não apenas com textos jornalísticos como As Farpas e "Chineses e Japoneses", mas também com a correspondência pessoal de Eça, conforme destacamos carta de 1889 ao Conde de Arnoso. 
Assim, fez-se de fundamental importância o nosso recorte abranger gêneros distintos de textos, uma vez que, uma análise restritiva a um gênero - romance ou textos jornalísticos - nos daria uma visão parcial da questão abordada.

As obras de Eça não se restringem a um diálogo interno. Os escritos queirosianos acabam por antever aspectos detalhados em teorias sociológicas do século XX, como as teorias orientalistas de Schwab, de 1950, e de Said, de 1978, embora, acreditamos, não seja possível amarrar definitivamente as obras de Eça a uma teoria ou a outra.

Por tudo que foi dito, vemos que, de um modo geral, o Extremo Oriente para Eça não foi um local de fuga, assim como não representou um "paraíso" buscado. Por outro lado, também não se apresentou como uma ameaça, como muitos de seu tempo enxergavam. E, principalmente, não se resumiu a um universo recheado de misticismo e exotismo. A visão do Extremo Oriente de Eça é, antes de tudo, plural. Parece-nos também um olhar bastante esclarecido, em que demonstra conhecer aspectos positivos e negativos, não considerando suas culturas nem superiores, nem inferiores à europeia. Porém, se o Oriente não ganha contorno nem demasiadamente positivo, nem excessivamente negativo, Eça parece se incomodar com o modo com que Ocidente e Oriente se relacionam. Desse modo, destaca-se a falta de interlocução entre as partes apontada por nosso autor, que reconhece julgamentos mútuos, do europeu em relação ao asiático e do asiático em relação ao europeu, análises unilaterais, resultando em incompreensão e desconhecimento. Desta maneira, tudo finda em uma impossibilidade de um convívio harmônico.

Tais leituras já destacariam fortemente nosso autor no cenário do orientalismo literário português. Mas, acrescentamos ainda outra contribuição de Eça de Queirós aos estudos orientalistas lusitanos: o autor de O Primo Basílio se diferencia de muitos de 
seus conterrâneos e contemporâneos ao pensar, em sua literatura, um Oriente presente $^{138}$. Eduardo Lourenço, em Labirinto da Saudade, destaca Eça de Queirós dentro do cenário oitocentista por pensar o Portugal contemporâneo ${ }^{139}$. Aqui, estendemos esta leitura ao afirmar que Eça refletiu não apenas sobre Portugal, mas também sobre o Oriente de sua contemporaneidade, mesmo quando trata do passado. Deste modo, nosso autor se torna mais relevante para a compreensão do orientalismo oitocentista português do que a crítica já julgou em momentos anteriores.

Lembramos que nosso estudo não é uma conclusão. Mas sim uma reflexão que visa contribuir para os estudos queirosianos ao retomar uma questão que busca um olhar mais acurado. Não esgotamos - e nem nosso objetivo era - a questão do Oriente em Eça de Queirós. Carece, por exemplo, um estudo mais globalizante dos textos que retratam o Oriente Próximo, como O Egito (1926), A Relíquia (1887), textos jornalísticos como “De Port-Said a Suez" (1869), “Os Ingleses no Egito”(1882), entre outros, embora existam importantes análises independentes de muitas dessas obras. Necessita-se ainda um estudo mais detalhado de como os companheiros de geração de Eça e outros escritores fora do círculo da Geração de 70 enxergaram o Oriente para que possamos, enfim, entender mais amplamente como o orientalismo literário oitocentista português se desenvolveu.

Finalizamos nosso estudo reafirmando que nos parece claro que as problemáticas envolvendo as relações entre Oriente e Ocidente, tão presente no século XIX, não deixariam de se tratadas pelo autor de Os Maias. Assim, Eça de Queirós parece ser consciente que esta questão não é simples. Se ele não se arrisca a propor uma

\footnotetext{
${ }^{138}$ Recordamos que, com as comemorações camonianas de 1880 e do quarto centenário da chegada de Vasco da Gama às Índias em 1898, são inúmeras as obras literárias que louvam as conquistas portuguesas do século XVI, conforme pode-se depreender também a partir do quadro remontado no item 1.2 deste trabalho.

139 "De todas as interpretações da realidade nacional da Geração de 70 [...] a mais complexa, a mais obsessiva, ardente, fina e ao fim e ao cabo a mais bem sucedida [...] é sem dúvida a de Eça de Queirós. Apesar de todas as críticas que se lhe podem fazer, é um Portugal realmente presente que ele interroga e que o interpela" (LOURENÇO, 2009, p. 95, grifo do autor).
} 
solução definitiva para a conturbada relação, parece-nos que deixa nas entrelinhas de seus textos um possível caminho de conciliação: o diálogo. E, sob este ponto de vista, o Oriente queirosiano se torna objeto interessante para nós, leitores de Eça no século XXI. Afinal, claramente, é possível notar que, apesar de já ter se passado mais de um século da morte de nosso autor e de vivermos num mundo visto como globalizado, no fundo, pouco mudaram as visões mútuas desses dois "blocos". Portanto, as representações do Extremo Oriente nos textos de Eça de Queirós são de grande relevância para entendermos a relação Ocidente-Oriente em nossa contemporaneidade, uma vez que, suas imagens, são inequivocamente atuais. 


\section{REFERÊNCIAS BIBLIOGRÁFICAS}

\section{OBRAS DE EÇA DE QUEIRÓS}

\section{Textos ficcionais}

QUEIRÓS, Eça de, ORTIGÃO Ramalho. O Mistério da Estrada de Sintra. Porto: Lello \& Irmão Editores, 1951.

Singularidades de uma Rapariga Loura. In: Obras Completas de Eça de Queiróz. Vol. 1. Porto: Lello \& Irmão Editores, p.705-724, 1958.

Os Maias. In: Obras Completas de Eça de Queiróz. Vol. 2. Porto: Lello \& Irmão Editores, p.5-496, 1958.

O Conde de Abranhos. In: Obras Completas de Eça de Queiróz. Vol. 3. Porto: Lello \& Irmão Editores, p.288-405, 1958.

O Mandarim. Edição Crítica das Obras de Eça de Queirós. BERRINI, Beatriz (org.) Lisboa: Imprensa Nacional-Casa da Moeda, 1992a.

A Capital! (Começos duma carreira). Edição Crítica das Obras de Eça de Queirós. DUARTE, Luiz Fagundes (org.). Lisboa, Imprensa Nacional-Casa da Moeda, 1992b.

A Correspondência de Fradique Mendes. In. Eça de Queiroz Obra Completa. BERRINI, Beatriz (org.). Vol. 2. Rio de Janeiro: Nova Aguilar, p. 52-204, 1997.

O Crime do Padre Amaro ( $2^{a}$ e $3^{a}$ versões). Edição Crítica das Obras de Eça de Queirós.. REIS, Carlos e CUNHA, Maria do Rosário (org.) Lisboa, Imprensa Nacional-Casa da Moeda, 2000b.

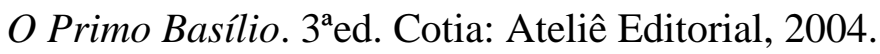

A Cidade e as Serras. Cotia: Ateliê Editorial, 2011.

\section{Textos de imprensa}

Notas do mês. In: Edição Crítica das Obras de Eça de Queirós. Textos de Imprensa VI (da Revista de Portugal). SANTANA, Maria Helena (org.). Lisboa: Imprensa NacionalCasa da Moeda, p. 55-61, 1995.

Misticismo Humorístico. In: In: Eça de Queiroz Obra Completa. BERRINI, B. (org.) Vol. 3. Rio de Janeiro: Nova Aguilar, p. 74-77, 2000a.

I. In: Eça de Queiroz Obra Completa. BERRINI, B. (org.) Vol. 3. Rio de Janeiro: Nova Aguilar, p. 663-678, 2000a.

XVIII. In: Eça de Queiroz Obra Completa. BERRINI, B. (org.). Vol. 3. Rio de Janeiro: Nova Aguilar, p. 720-726, 2000a. 
XXXIV. In: Eça de Queiroz Obra Completa. BERRINI, B. (org.)Vol. 3. Rio de Janeiro: Nova Aguilar, p. 750-755, 2000a.

A Europa em Resumo. In: Edição Crítica das Obras de Eça de Queirós. Textos de Imprensa IV (da Gazeta de Notícias). MINÉ, Elza e CAVALCANTE, Neuma (org.). Lisboa: Imprensa Nacional-Casa da Moeda, p. 231-238, 2002.

13 de Agosto de 1893. In: Edição Crítica das Obras de Eça de Queirós. Textos de Imprensa IV (da Gazeta de Notícias). MINÉ, Elza e CAVALCANTE, Neuma (org.). Lisboa: Imprensa Nacional-Casa da Moeda, p. 365-370, 2002.

20 de Agosto de 1893. In: Edição Crítica das Obras de Eça de Queirós. Textos de Imprensa IV (da Gazeta de Notícias). MINÉ, Elza e CAVALCANTE, Neuma (org.). Lisboa: Imprensa Nacional-Casa da Moeda, p. 371-375, 2002.

Chineses e Japoneses. In: Edição Crítica das Obras de Eça de Queirós. Textos de Imprensa IV (da Gazeta de Notícias). MINÉ, Elza e CAVALCANTE, Neuma (org.). Lisboa: Imprensa Nacional-Casa da Moeda, p. 527-546, 2002.

A Propósito da Doutrina Monroe e do Nativismo. In In: Edição Crítica das Obras de Eça de Queirós. Textos de Imprensa IV (da Gazeta de Notícias). MINÉ, Elza e CAVALCANTE, Neuma (org.). Lisboa: Imprensa Nacional-Casa da Moeda, p. 585605, 2002.

França e Sião. In: Edição Crítica das Obras de Eça de Queirós. Textos de Imprensa V (da Revista Moderna). SOLER, Elena Losada (org.). Lisboa: Imprensa Nacional-Casa da Moeda, p. 75-82, 2005.

\section{Correspondência pessoal}

20. Newcastle 28 novembro 78. In: Eça de Queiroz Obras Completas. BERRINI, B. (org.). Vol. 4. Rio de Janeiro: Nova Aguilar, p. 131-135, 2000a.

23. Bristol 20 de fevereiro de 1881. In: Eça de Queiroz Obras Completas. BERRINI, B. (org.). Vol. 4. Rio de Janeiro: Nova Aguilar, p. 138-141, 2000a.

24 de outubro de 1890. In: Eça de Queiroz Obra Completa. BERRINI, B. (org.). Vol. 4. Rio de Janeiro: Nova Aguilar, p. 168-169, 2000a.

7. Bristol 10 de junho de 1885. In: Eça de Queiroz Obra Completa. BERRINI, B. (org.). Vol. 4. Rio de Janeiro: Nova Aguilar, p. 240-241, 2000a.

Bristol 23 de maio de 1888. In: Eça de Queiroz Obra Completa. BERRINI, B. (org.). Vol. 4. Rio de Janeiro: Nova Aguilar, p. 245-247, 2000a.

35. Paris 17 abril 1893. In: In: Eça de Queiroz Obra Completa. BERRINI, B. (org.). Vol. 4. Rio de Janeiro: Nova Aguilar, p. 282-283, 2000a.

11. Domingo 1889. In: Eça de Queiroz Obra Completa. BERRINI, B. (org.). Vol. 4. Rio de Janeiro: Nova Aguilar, p. 301, 2000a 
4. Newcastle 5 de outubro de 1877. In.: Eça de Queiroz Obras Completas. BERRINI, B. (org.). Vol. 4. Rio de Janeiro: Nova Aguilar, p. 824-825, 2000a.

\section{Outros textos}

Um Gênio que era um Santo. In.: Eça de Queiroz. Obras Completas. BERRINI, B. (org.). Vol. 3. Rio de Janeiro: Nova Aguilar, p. 1761-1787, 2000a.

A Emigração como Força Civilizadora. In: Eça de Queiroz Obras Completas. BERRINI, B. (org.). Vol. 3. Rio de Janeiro: Nova Aguilar, p. 1999-2084, 2000a.

\section{BIBLIOGRAFIA CITADA}

AHMAD, Aijaz. Orientalismo e depois: ambivalência e posição metropolitana na obra de Edward Said. In: Linhagens do Presente. Trad. Sandra Guardini Vasconcelos. São Paulo: Boitempo Editorial, p. 109-165, 2002.

BERRINI, Beatriz. Introdução. In: Edição Crítica das Obras de Eça de Queirós. O Mandarim. Lisboa: Imprensa Nacional da Casa da Moeda, p. 15-74, 1992.

BERRINI, Beatriz. A China na vida e na obra. In: CAMPOS MATOS, A. (org.) Dicionário de Eça de Queirós. Lisboa: Caminho, p. 196-200, 1993.

BERRINI, Beatriz. Nota Preliminar. In: Eça de Queiroz Obra Completa. Vol. 3. Rio de Janeiro: Nova Aguilar, p. 1551-1553, 2000.

BUENO, Aparecida de Fátima. "Sob o manto diáfano da fantasia: os cristos de Eça" In: Revista Lusófona de Ciência das Religiões. Ano VI, n. 11. Lisboa: Universidade Lusófona de Humanidades e Tecnologias p. 307-314, 2007.

CAMPOS MATOS, A. (org.). Dicionário de Eça de Queirós. Lisboa: Caminho, 1988.

CAMPOS MATOS, A. “(O) Mistério da Estrada de Sintra”. In: Dicionário de Eça de Queiroz. Lisboa, Caminho, p. 406-407, 1988.

CARREIRA, Ernestina. Índia. In: Nova História da Expansão Portuguesa. O Império Africano 1825-1890. SERRÃO, Joel e OLIVEIRA MARQUES, A. H. (dir.). Vol. X. Lisboa: Editorial Estampa, p. 657-717, 1998.

CASTRO, Andréa Trench de. O romance-folhetim de Camilo Castelo Branco e Eça de Queirós. Dissertação (Mestrado em Letras) Faculdade de Filosofia Letras e Ciências Humanas, Universidade de São Paulo, São Paulo, 2012.

COUTO, Marcos Miguel Oliveira do. Representações do Oriente em O Mundo Português (1934-1947). Dissertação (mestrado em História Contemporânea). Faculdade de Letras, Universidade do Porto, Porto, 2011.

DANTAS, Luiz. Apresentação à primeira edição. In: AZEVEDO, Aluísio. O Japão. Rio de Janeiro: Biblioteca Nacional, p. 163-220, 2010. 
DAVID, Sérgio Nazar. Duas faces da renúncia em 'O Mandarim' de Eça de Queirós. In.: O Século de Silvestre da Silva. Estudos Queirosianos. Vol. 2. Rio de Janeiro: 7Letras, p. 49-80, 2007.

FEITAIS, Paulo. Antero de Quental foi budista? In.: Revista Lusófona de Ciência das Religiões. Ano VI, n. 11. Lisboa: Universidade Lusófona de Humanidades e Tecnologias, p. 109-124, 2007.

FIGUEIREDO, Monica. Entre "coolies" e mandarins, as inscrições chinesas em Eça de Queirós. In: Literatura Portuguesa Aquém-mar. FERNANDES Annie Gisele, OLIVEIRA, Paulo Motta (orgs.). Campinas: Komedi, p.107-121, 2005.

FRIER, David G. "Sim ou a Vã Glória de Mandar": Money, Power and Remorse in Eça's O Mandarim. In.: Luso-Brazilian Review. Vol. 47, $\mathrm{n}^{\circ} 1$. Winconsin: University of Winconsin Press, p. 150-167, 2010.

GAMBA, Ana Paula Foloni. O Mandarim (Eça de Queiroz): a sociedade portuguesa do século XIX à luz da sátira menipéia. Dissertação (mestrado em Letras). Faculdade de Ciências e Letras. Universidade Estadual Paulista "Júlio de Mesquita Filho", Assis, 2005.

GARMES, Hélder. A Cultura Sino-portuguesa no Século XIX e o Ta-ssi-yang-kuo. In: Via Atlântica, no. 6. São Paulo: FFLCH, p. 65-82, 2003.

GARMES, Hélder. Origem e estabelecimento da imprensa e da literatura em Goa. In: Oriente, Engenho e Arte - Imprensa e literatura de língua portuguesa em Goa, Macau e Timor Leste. São Paulo: Alameda Casa Editorial, p.15-85, 2004.

GARMES, Hélder. As Fronteiras da Civilização em Eça de Queirós. In: FERNANDES, Annie Gisele e OLIVEIRA, Paulo Motta (org.). Literatura Portuguesa Aquém-mar. Campinas: Komedi, p.53-71, 2005.

GROSSEGESSE, Orlando. O fantasma do chinês deschinesado. In: QUEIRÓS, Eça de. Chineses e Japoneses. Lisboa: Fundação Oriental, p. 7-26, 1997.

GROSSEGESSE, Orlando. Das Leituras do Oriente à Aventura da Escrita. A Propósito de "O Mandarim" e "A Relíquia". In: Eça de Queiroz. Obras Completas. BERRINI, Beatriz (org.) Rio de Janeiro: Nova Aguilar, p.767-780, 2000.

GROSSEGESSE, Orlando. Analisar, Conversar ou Filosofar? Sobre a Evolução da Escrita Queirosiana na Imprensa. In: BERRINI, Beatriz (org.) Eça e Machado. São Paulo: EDUC - Editora PUC-SP, p. 131-154, 2005.

HESPANHA, António Manuel. O Orientalismo em Portugal (séculos XVI-XX). In: RODRIGUES, Ana Maria (coord.) O Orientalismo em Portugal. Porto: Edifício da Alfândega, p. 15-37, 1999. 
HORIGOSHI, Érika. Para entender o Japão: aspectos da cultura japonesa em textos de Wenceslau de Moraes. Dissertação (mestrado em Letras). Faculdade de Filosofia Letras e Ciências Humanas, Universidade de São Paulo, São Paulo, 2012.

JORGE, Carlos Jorge Figueiredo. A corrida contra a morte e a demanda do arrependimento em Les Tribulation d'um Chinois em Chine, de Julio Verne e $O$ Mandarim, de Eça de Queirós. In.: LABORINHO, Ana Paula et ali. (org). A Vertigem do Oriente. Modalidades discursivas no encontro de culturas. Lisboa-Macau: Edições Cosmos e Instituto Português no Oriente, p. 243-256, 1999.

KALEWSKA, Anna. A fortuna cultural do prefácio a O Mandarim de Eça de Queirós: a correspondência de Ladislao Mickiewicz e Oliveira Martins como fator de internacionalização de Eça. In.: Congresso de Estudos Queirosianos. IV Encontro internacional de Queirosianos. Actas. Vol. 1. Coimbra: Almedina e Universidade de Coimbra, p. 380-391, 2002.

KUNIYOSHI, Celina. Imagens do Japão - uma utopia de viajantes. São Paulo: Estação Liberdade e FAPESP, 1998

LARA, Dalila Andrade. Representações dos espaços fantásticos do Oriente sob a ótica ocidental: uma análise de O Mandarim e A Relíquia de Eça de Queirós. Dissertação (Mestrado em Letras). Instituto de Letras e Linguística. Universidade Federal de Uberlândia, Uberlândia, 2012.

LIMA, Isabel Pires de. L'imaginaire oriental chez Flaubert et Eça de Queirós - Le Voyage en Egypte. In: Intercambio. Porto: Universidade do Porto. Faculdade de Letras, p. 19-33, 1991.

LIMA, Isabel Pires de. Os Orientes de Eça de Queirós. In: Revista Semear, nº 1 . Rio de Janeiro: PUC-RJ, p. 81-95, 1997.

LIMA, Isabel Pires de. O Orientalismo na Literatura Portuguesa (Séculos XIX e XX). In: RODRIGUES, Ana Maria (coord.) O Orientalismo em Portugal. Porto: Edifício da Alfândega, p.145-160, 1999.

LOURENÇO, Eduardo. Fernando, Rei da nossa Baviera. Lisboa: Gradiva, 2008.

LOURENÇO, Eduardo. O Labirinto da Saudade. $6^{\mathrm{a}}$ ed. Lisboa: Gradiva, 2009.

MACHADO, Álvaro Manuel. O Mito do Oriente na Literatura Portuguesa. Lisboa: ICALP (Biblioteca Breve), 1983.

MAGALHÃES, José Calvet de. Eça de Queirós, cônsul e escritor. In: Revista Camões, n. 9-10. Lisboa: Instituto Camões, p. 8-22, 2000.

MARTINS, Antônio Coimbra. O Mandarim Assassinado. In: Ensaios Queirosianos. Lisboa: Europa-América, p. 10-266, 1967.

MEDINA, João. Eça de Queiroz e seu tempo. Lisboa: Livros Horizonte, 1972. 
MEDINA, João. A tradução francesa d'O Mandarim publicada na 'Revue Universelle Internationale' em 1884. In: Eça de Queiroz e a Geração de 70. Lisboa: Moraes Editora, p. 117-125, 1980.

MEDINA, João. (As) Farpas. In: Dicionário de Eça de Queirós. CAMPOS MATOS, A. (org.) Lisboa: Caminho, p. 261-266, 1988.

MINÉ, Elza. Eça de Queirós Jornalista. Lisboa: Livros Horizonte, 1986.

MINÉ, Elza. Páginas Flutuantes. Eça de Queirós e o jornalismo no século XIX. Cotia: Ateliê Editorial, 2000a.

MINÉ, Elza. Eça jornalista no Brasil. In: Ecos do Brasil. Eça de Queirós - Leituras brasileiras e portuguesas. ABDALA JR., Benjamin (org.). São Paulo: Editora Senae, p. 39-67, 2000b.

MÓNICA, Maria Filomena. Eça de Queirós. Lisboa: Quetzal, 2009.

MONTEIRO, Ofélia Paiva. "Um jogo humorístico com a verossimilhança narrativa: O Mistério da Estrada de Sintra". In: Revista Colóquio/Letras. Letras, n86, p.15-23, 1985; n'97, p. 5-18, 1987; nº8, p. 38-51, 1987.

MONTEIRO, Ofélia Paiva. "(O) Mistério da Estrada de Sintra”. In: CAMPOS MATOS, A. (org.). Dicionário de Eça de Queiroz. Lisboa: Caminho, p. 407-409, 1988.

MONTEIRO, Ofélia Paiva. Sobre a excentricidade humorística de Fradique. In: Queirosiana. Estudos sobre Eça de Queirós e sua geração, nº5/6. Tormes: Associação de Amigos de Eça de Queirós, p. 193-226, 1993/1994.

NEEDHAM, Joseph. Science and civilization in China. vol. 1. Cambridge: Cambridge University Press, 1954.

NERY, Antonio Augusto. Diabos (diálogos) intermitentes: individualismo e crítica à instituição religiosa em obras de Eça de Queirós. 2010. Tese (Doutorado em Literatura Portuguesa) Faculdade de Filosofia Letras e Ciências Humanas, Universidade de São Paulo, São Paulo, 2010.

OKAKURA, Kakuzo. O livro do chá. Trad. Leiko Gotoda. São Paulo: Estação Liberdade, 2008.

OLIVA, Osmar Pereira. Machado de Assis, Joaquim Nabuco e Eça de Queirós e a imigração chinesa - qual medo? In: Revista da ANPOLL, n. 24, v. 2. Brasília: UnB, p. 66-84, 2008.

OLIVEIRA MARQUES, A. H. de. História de Portugal. Lisboa: Palas, 1983.

OLIVEIRA, Maria Lúcia Wiltshire de. O Oriente como fonte de imaginação em Eça de Queirós. In: SCARPELLI, Marli Fantini e OLIVEIRA, Paulo Motta (org.) Os Centenários: Eça, Freyre e Nobre. Belo Horizonte: FALE/UFMG, p. 239-251, 2001. 
OLIVEIRA, Paulo Motta. Fradique Mendes: Eça, a heteronímia e o vencidismo. In: Veredas. Vol. 3, tomo I. Porto: p. 185-193, 2000.

OLIVEIRA, Paulo Motta. Eça: Fradique, Ramires e outros viajantes de papel. In: Ipotesi. Vol. 5, n. 2. Juiz de Fora-MG: p. 155-164, 2001.

PEIXINHO, Ana Teresa. Epistolaridade e narratividade nas cartas de Fradique Mendes: análise de uma carta a Ramalho Ortigão. In: Congresso de Estudos Queirosianos. IV Encontro internacional de Queirosianos. Actas. Vol. 1. Coimbra: Almedina e Universidade de Coimbra, p. 339-351, 2002.

PIEDADE, Ana Nascimento. Estratégias da modernidade em A Correspondência de Fradique Mendes. In. Congresso de Estudos Queirosianos. IV Encontro internacional de Queirosianos. Actas. Vol. 1. Coimbra: Almedina e Universidade de Coimbra, p. 295314, 2002.

PIEDADE, Ana Nascimento. Fradiquismo e Modernidade no Último Eça. Lisboa: Imprensa Nacional-Casa da Moeda. 2003.

QUENTAL, Antero de. Causas da decadência dos povos peninsulares nos últimos três séculos. In: Prosas Sócio-políticas. Lisboa: Imprensa Nacional - Casa da Moeda, p. 255-296, 1982.

QUINET, Edgard. De la Renaissance Orientale. Paris: L'archange Minotaure, 2003.

RAMOS, Manuela Delgado Leão. António Feijó e Camilo Pessanha no Panorama do Orientalismo Português. Lisboa: Fundação Oriente, 2001.

REAL, Miguel. O Último Eça. Lisboa: Quidnovi, 2006.

REAL, Miguel. A Visão do Budismo em Eça de Queirós. In: Revista Lusófona de Ciência das Religiões. Ano VI, n. 11. Lisboa: Universidade Lusófona de Humanidades e Tecnologias, p. 125-137, 2007.

REIS, Carlos. Estatuto e Perspectivas do Narrador na ficção de Eça de Queirós. $3^{\mathrm{a}}$ ed. Coimbra: Almedina, 1984.

REIS, Carlos. Para a edição crítica das obras de Eça de Queirós. In: Eça e os Maias: Actas do $1^{\circ}$ Encontro Internacional de Queirosianos. Lisboa: Edições ASA, p. 227-234, 1990.

REIS, Carlos. Eça de Queirós. Consul de Portugal à Paris. Paris: Centre Culturel C. Gulbenkian - Portugal, 1997.

REIS, Carlos. Fradique Mendes: origem e modernidade de um projecto heteronímico. In: Estudos Queirosianos. Ensaios sobre Eça de Queirós e a sua obra. Lisboa: Presença, p. 137-155, 1999.

REIS, Carlos. Introdução. In: QUEIRÓS, Eça de. O Mandarim. Lisboa: Editorial Presença, p. 9-22, 2003. 
REIS, Jaime Batalha. Introdução. In: Obra Completa de Eça de Queiroz. Vol. 1. Porto: Lello \& Irmão Editores, p.543-569, 1958.

REIS, Jaime Batalha. Anos de Lisboa (Algumas lembranças). In: SERRÃO, Joel. $O$ Primeiro Fradique Mendes. Lisboa: Horizonte, p. 315-322, 1985.

ROBERTS, J. A. G. A Concise History of China. Cambridge: Harvard University Press, 1999.

ROMANO, Fernanda Maria. António Feijó e Camilo Pessanha: interlocuções poéticas em traduções. 2013. 171f. Tese (doutorado). Faculdade de Filosofia Letras e Ciências Humanas, Universidade de São Paulo, São Paulo, 2013.

SAID, Edward W. O orientalismo reconsiderado. In: Reflexões sobre o exílio e outros ensaios. São Paulo, Companhia das Letras, p. 61-78, 2003.

SAID, Edward W. Orientalismo - O Oriente como invenção do Ocidente. Trad. Rosaura Eichenberg. São Paulo: Companhia de Bolso, 2008.

SANTOS, Giuliano Lellis Ito. A ideia de História no último Eça. 2010. 229f. Tese (doutorado). Faculdade de Filosofia Letras e Ciências Humanas, Universidade de São Paulo, São Paulo, 2011.

SAPEGA, Ellen W. O Oriente do Sonho e o Sonho do Oriente n'O Mandarim. In.: Congresso de Estudos Queirosianos. IV Encontro internacional de Queirosianos. Actas. Vol. 1. Coimbra: Almedina e Universidade de Coimbra, , p. 443-450, 2002.

SARAIVA, António José. Tertúlia Ocidental. $2^{a}$ ed. Lisboa: Gradiva, 1995.

SARAIVA, António José. As Ideias de Eça de Queirós. Lisboa: Gravida, 2000.

SCHWAB, Raymond. La Renaissance Orientale. Paris: Payot, 1950.

SEQUEIRA, Maria do Carmo Castelo Branco de. A Dimensão Fantástica na Obra de Eça de Queirós. Porto: Campo das Letras, 2002.

SERRÃO, Joel. Cesário Verde. $2^{\mathrm{a}}$ ed. Lisboa: Delfos, 1961.

SERRÃO, Joel. O Primeiro Fradique Mendes. Lisboa: Horizonte, 1985.

SERRÃO, José Vicente. Macau. In: Nova História da Expansão Portuguesa. O Império Africano 1825-1890. SERRÃO, Joel e OLIVEIRA MARQUES, A. H. (dir.). Vol. X. Lisboa: Editorial Estampa, p. 719-765, 1998.

SILVESTRE, Osvaldo Manuel. Um turista nos trópicos: o devir pós-colonial de Fradique Mendes. In.: Congresso de Estudos Queirosianos. IV Encontro internacional de Queirosianos. Actas. Vol. 1. Coimbra: Almedina e Universidade de Coimbra, p. 221$240,2002$. 
SIMAS, Monica. Margens do Destino. Macau e a literatura em língua portuguesa. São Caetano do Sul: Yendis, 2007.

SIMÕES, João Gaspar. Vida e Obra de Eça de Queirós. Lisboa: Livraria Bertrand, 1973.

SIQUEIRA, José Carlos. O romance-ensaio de Eça de Queirós. Estudo crítico sobre A ilustre casa de Ramires e A cidade e as serras. Tese (doutorado). $250 \mathrm{f}$. Universidade de São Paulo, São Paulo, 2011.

THIMÓTEO, Natália Gomes. Fradique Mendes e o ideário da "geração de 70". In: Congresso de Estudos Queirosianos. IV Encontro internacional de Queirosianos. Actas. Vol. 1. Coimbra: Almedina e Universidade de Coimbra, p. 831-839, 2002.

VERNE, Júlio. Atribulações de um chinês na China. Trad. Ivan Pedro Cesar da Cunha. Rio de Janeiro: Otto Pierre Editores, 1982. 